\title{
A ORIGEM DOS DOBRAMENTOS EM CROSTAS FERRUGINOSAS DE PIRAPORA DO BOM JESUS-SP E DA BACIA TERCIÁRIA DE SĀO PAULO
}

\author{
Marcelo Altafini \\ Orientador Prof. Dr. Joel Barbujiani Sigolo \\ DISSERTAÇÃO DE MESTRADO \\ Área de Concentração: Geoquímica e Geotectônica \\ (Geoquímica dos Processos Exógenos)
}




\title{
A ORIGEM DOS DOBRAMENTOS EM CROSTAS FERRUGINOSAS DE PIRAPORA DO BOM JESUS-SP E DA BACIA TERCIÁRIA DE SÃO PAULO
}

\author{
MARCELO ALTAFINI
}

Orientador: Prof. Dr. Joel Barbujiani Sígolo

DISSERTAÇÃO DE MESTRADO

COMISSÃO JULGADORA

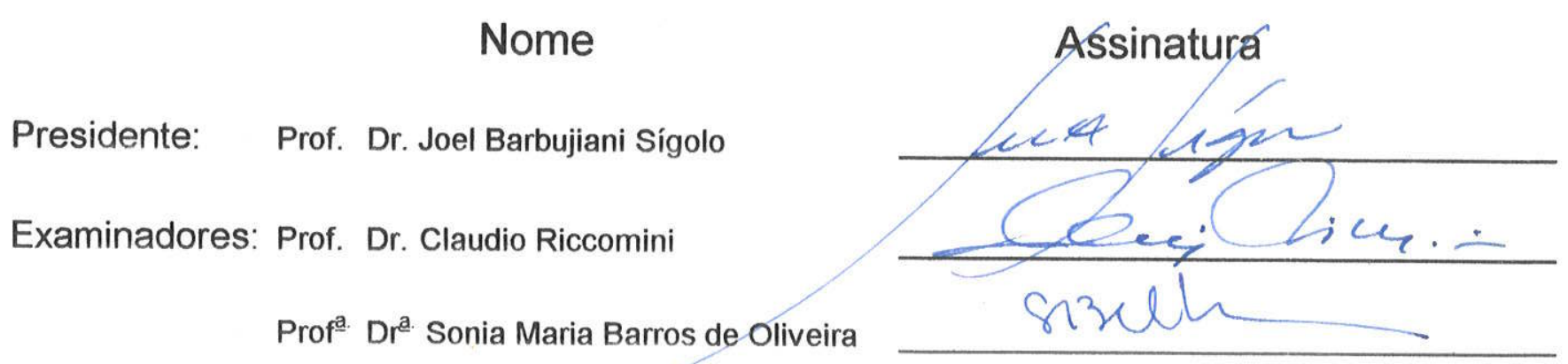

SÃO PAULO

1999 


\title{
UNIVERSIDADE DE SÃO PAULO INSTITUTO DE GEOCIÊNCIAS
}

DEDALUS - Acervo - IGC

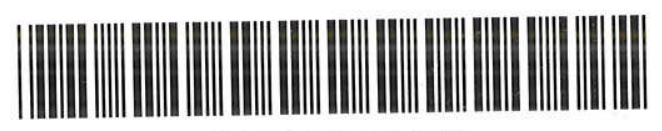

30900004462

\section{A ORIGEM DOS DOBRAMENTOS EM CROSTAS FERRUGINOSAS DE PIRAPORA DO BOM JESUS - SP E DA BACIA TERCIÁRIA DE SÃO PAULO}

Marcelo Altafini

Orientador: Prof. Dr. Joel Barbujiani Sígolo

\begin{abstract}
DISSERTAÇÃO DE MESTRADO
Área de Concentração: Geoquímica e Geotectônica

(Geoquímica dos Processos Exógenos)
\end{abstract}

São Paulo 
Página 4, linha 17 onde se lê (Suguio, 1980) leia-se Suguio, K. 1980 (1).

Página 8, legenda da figura III.2 onde se lê Mapa Geológico Regional (simplificado do Mapa Geológico do Estado de São Paulo), escala 1:500.000, 1984 - IPT-PRÓ MINÉRIO leia-se Mapa Geológico Regional (simplificado do Mapa Geológico do Estado de São Paulo, escala 1:500.000, IPT-PRÓ MINÉRIO, 1981.

Página 17, linha 23 onde se lê Observam-se, neste afloramento, quatro grupos distintos de fraturas ou eventuais falhas leia-se Observam-se neste afloramento quatro grupos distintos de fraturas e falhas, G1, G2, G3 e G4.

Página 18, linha 4 onde se lê $\mathrm{O}$ quarto conjunto leia-se $\mathrm{O}$ quarto grupo (G4).

Página 22, linha 6 onde se lê Para designar as amostras correspondentes à matriz foi utilizada leia-se Para designar as amostras correspondentes a matriz foi utilizado.

Pág 24, linha 27 onde se lê segundo- Bol. Cient.IG-USP Série Cient. Vol 26, pp 45-58, 1995) leia-se Janasi et al. (1996).

Pág 25, linha 19 onde se lê (crostas, couraça, matriz e rocha mãe) leia-se (crostas ferruginosas, matriz e sedimentos encaixantes).

Página 28, legenda da figura V.2, linha 4 onde se lê reprecipitação de ferro leia-se reprecipitação de hidróxidos de ferro.

Página 64, linha 7 onde se lê analizados leia-se analisados.

Página 65 desconsiderar linhas 1 e 2.

Página 66, linha 3 onde se lê enriquecidas em ferro leia-se enriquecidas em hidróxidos de ferro.

Página 66, linha 4 onde se lê aparecendo como manchas esbranquiçadas. leia-se aparecendo como manchas esbranquiçadas na figura V.65.

Página 94, linha 13 onde se lê Suguio, K. 1980 leia-se Suguio, K. 1980 (1).

Página 94, linha 15 onde se lê Suguio, K. 1980 leia-se Suguio, K. 1980 (2). 
Dedico esta dissertação de mestrado ao meu pai Vilson Altafini 


\section{ÍNDICE}

Pág.

AGRADECIMENTOS $\quad x$

RESUMO

ABSTRACT

Capitulo I 1. INTRODUÇÃO

$\begin{array}{ll}\text { Objetivos } & 02\end{array}$

$\begin{array}{ll}\text { Proposta de Investigação } & 02\end{array}$

Capitulo II 2. DEFORMAÇÕES DE ORIGEM ATECTÔNICA

Capitulo III 3. ÁREAS ESTUDADAS 06

$\begin{array}{ll}\text { Localização } & 06\end{array}$

$\begin{array}{ll}\text { Geologia Regional } & 07\end{array}$

$\begin{array}{ll}\text { Geologia Local } & 11\end{array}$

Descrição dos Afloramentos 12

Rodovia Pres. Dutra (Área 1) 12

Rua Girassol, Vila Madalena (Área 2) 15

Estrada dos Romeiros, Pirapora do Bom Jesus (Área 3) 17

Capítulo IV 4. METODOLOGIA EMPREGADA 21

$\begin{array}{lr}\text { Amostragem } & 21\end{array}$

$\begin{array}{lr}\text { Análise Estrutural } & 22\end{array}$

$\begin{array}{ll}\text { Análise Macroscópica } & 23\end{array}$

$\begin{array}{ll}\text { Análise em Microscópio Óptico } & 23\end{array}$ 
Análises Químicas Pontuais Qualitativas e Semi-quantitativas em MEV/EDS 25

Análise de Minerais Pesados nos Diferentes Fácies 26

Determinação Mineral por Difração de Raios-X (DRX) das Frações Argilosas 26

Capitulo V

5. RESULTADOS OBTIDOS

27

RODOVIA PRES. DUTRA (ÁREA - 1)

Caracterização Mineralógica dos Materiais

Caracterização Microscópica

Comportamento Químico dos Elementos

Análises Químicas Totais

Análises Químicas Pontuais

RUA GIRASSOL, VILA MADALENA, SP (ÁREA - 2)

Caracterização Mìneralógica dos Materiais

Caracterização Microscópica

Determinações em DRX

Análise de Minerais Pesados

Comportamento Químico dos Elementos

Análises Químicas Totais

Análises Quimicas Pontuais

ESTRADA DOS ROMEIROS, PIRAPORA DO BOM JESUS, SP (ÁREA - 3)

Caracterização Mineralógica dos Materiais

Caracterização Microscópica 
Análise de Minerais Pesados

Comportamento Químico dos Elementos

Analises Quimicas Totais

58

Análises Químicas Pontuais

64

$\begin{array}{ll}\text { 5.1 ANÁLISE ESTRUTURAL } & 70\end{array}$

$\begin{array}{ll}\text { Rua Girassol, Vila Madalena (Área - 2) } & 70\end{array}$

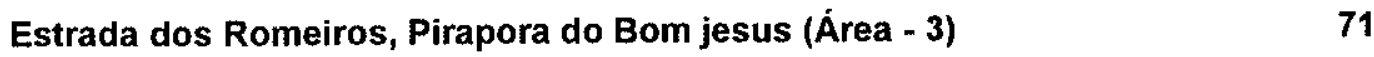

Capitulo VI 6. DISCUSSÕES

84

Capitulo VII 7. CONCLUSÕES

90

Capitulo VIII 8. BIBLIOGRAFIA

92 


\section{FIGURAS}

Figura III.1: Mapa de Localização das Áreas Estudadas.

Pág.

Figura III.2: Mapa Geológico Regional (simplificado do Mapa Geológico do Estado de São

Figura III.2: $\quad$ Paulo), escala 1:500.000, 1984 IPT-PRÓ-MINÉRIO.

Figura III.3: Fotografia do afloramento do Km 214,5 da Rodovia Presidente Dutra (Área 1).

Figura III.4: Fotografia de estruturas circulares tipo Anéis de Liesegang, formadas por percolação de hidróxido de ferro do afloramento do $\mathrm{Km} \mathrm{214,5}$ da Dutra (Área 1).

Figura III.5: Fotografia - Vista geral do afloramento do Km 214,5 da Dutra (Área 1).

Figura III.6:

Fotografia de couraça fragmentada do afloramento do Km 214,5 da Dutra (Área 1).

Figura III.7: Fotografia exibindo crostas ferruginosas deformadas, semelhantes a estruturas sedimentares primárias da Dutra (Área 1).

Figura III.8: Fotografia de detalhe das crostas deformadas. Afloramento do $\mathrm{Km} \mathrm{211,5}$ da Dutra (Área 1).

Figura III.9: Fotografia das crostas ferruginosas dobradas da porção esquerda do afloramento da Vila Madalena (Área 2).

Figura III.10: Croqui esquemático do afloramento da Vila Madalena (Área 2), exibindo a localização dos perfis de amostragem.

Figura III.11: Fotografia das crostas ferruginosas dobradas da porção direita do afloramento da Rua Girassol, Vila Madalena (Área 2).

Figura III.12: Fotografia das crostas ferruginosas dobradas da porção esquerda do afloramento da Vila Madalena (Área 2).

Croqui esquemático do afloramento de Pirapora (Área 3), exibindo a localização

Figura III.13: dos perfis de amostragem e os grupos de fraturas.

Figura III.14: Fotografia - Vista geral do afloramento de Pirapora (Área 3).

Figura III.15: Fotografia da porção do afloramento de Pirapora (Área 3) onde ocorrem as "dobras" nas crostas ferruginosas.

Figura III.16: Fotografia (detalhe) exibindo nódulos maciços amarelados de argila e "condutos" preenchidos por material argiloso esbranquiçado (Pirapora - Área 3).

Figura III.17: Fotografia das crostas ferruginosas deformadas intercaladas por sedimento argilo-arenoso (Pirapora - Área 3).

Figura III.18: Fotografia de parte do afloramento de Pirapora (Área 3), exibindo três conjuntos de fraturas.

Figura V.1: Fotomicrografia $(\mathrm{LN})$ da região de contato entre o plasma marrom avermelhado da crosta e o plasma amarelado da matriz (Dutra - Área 1).

Figura V.2: Fotomicrografia $(L N)$ exibindo estrutura de preenchimento concêntrico formada por material argilo-feruginoso (Dutra - Área 1). 
Figura V.3: Comportamento geoquímico do $\mathrm{Si}, \mathrm{Al}$ e do $\mathrm{Fe}$ ao longo dos perfis estudados (Dutra - Área 1).

Figura V.4: Diagrama geoquímico discriminativo $\mathrm{Fe}_{2} \mathrm{O}_{3} \times \mathrm{Al}_{2} \mathrm{O}_{3} \times \mathrm{SiO}_{2}(\%)-$ Distribuição dos campos de agrupamento das amostras (Dutra - Área 1).

Figura V.5: Diagrama geoquímico discriminativo $\mathrm{Fe}_{2} \mathrm{O}_{3} \times \mathrm{SiO}_{2}(\%)($ Dutra - Área 1).

Figura V.6: Diagrama geoquímico discriminativo $\mathrm{Fe}_{2} \mathrm{O}_{3}+\mathrm{Al}_{2} \mathrm{O}_{3} \times \mathrm{SiO}_{2}$ (\%) (Dutra - Área 1).

Figura V.7: Espectro de EDS com análise química qualitativa da região da crosta ferruginosa (Dutra - Área -1).

Figura V.8: Espectro de EDS com análise química qualitativa da região da matriz (Dutra Área -1).

Figura V.9: Fotomicrografia (LP) do plasma da região da matriz, grãos de quartzo e fragmentos de mica (Vila Madalena - Área 2).

Figura V.10: Fotomicrografia (LP) de grão de quartzo cortado por fissura preechida por hidróxidos de ferro (Vila Madalena - Área 2).

Figura V.11: Fotomicrografia (LN) - Contato entre plasma da crosta ferruginosa e plasma da matriz. Fissuras preenchidas por material granulado (Vila Madalena - Área 2).

Fotomicrografia (LN) - Estruturas de preenchimento esferoidais (Vila Madalena Área 2).

Figura V.12

Fotomicrografia (LN) - Estrutura de preenchimento esferoidal - Material argilo-

Figura V.13: ferruginoso (ferriargilan) (Vila Madalena - Área 2).

Fotomicrografia (LN) - Cavidade preenchida por material argilo-ferruginoso,

Figura V.14: $\quad \begin{aligned} & \text { Fotomicrografia (LN) - Cavidade preenchida por mater } \\ & \text { formando estrutura concêntrica (Vila Madalena Área 2). }\end{aligned}$

$\begin{array}{ll}\text { Figura V.15: } & \text { Fotomicrografia (LN) - Estrutura de preenchimento com fragmentação de } \\ & \text { ferriargilans e redeposição de hidroxidos de ferro (Vila Madalena - Área 2). }\end{array}$

Figura V.16: Fotomicrografia (LN) - Aspecto geral do plasma da crosta ferruginosa, exibindo fissura preenchida por hidróxido de ferro (Vila Madalena - Área 2).

Figura V.17: Resultados da análise por DRX da amostra da matriz (Vila Madalena - Área 2).

Figura V.18: Resultados da análise por DRX da amostra da crosta (Vila Madalena - Área 2).

Figura V.19: Comportamento geoquímico dos elementos $\mathrm{Si}$, $\mathrm{Al}$ e do $\mathrm{Fe}$ ao longo dos perfis estudados (Vila Madalena - Área 2).

Figura V.20: Diagrama geoquímico discriminativo $\mathrm{Fe}_{2} \mathrm{O}_{3} \times \mathrm{SiO}_{2}(\%)$, exibindo a distribuição dos campos de agrupamento das amostras (Vila Madalena - Área 2).

$\begin{array}{ll}\text { Figura V.21: } & \text { Diagrama geoquímico discriminativo } \mathrm{Fe}_{2} \mathrm{O}_{3} \times \mathrm{Al}_{2} \mathrm{O}_{3}(\%) \text {, exibindo a distribuição } \\ \text { dos campos de agrupamento das amostras (Vila Madalena - Área 2). }\end{array}$

$\begin{array}{ll}\text { Figura V.21: } & \text { Diagrama geoquímico discriminativo } \mathrm{Fe}_{2} \mathrm{O}_{3} \times \mathrm{Al}_{2} \mathrm{O}_{3}(\%) \text {, exibindo a distribuição } \\ \text { dos campos de agrupamento das amostras (Vila Madalena - Área 2). }\end{array}$

$\begin{array}{ll}\text { Figura V.22: } & \text { Diagrama geoquímico discriminativo } \mathrm{SiO}_{2} \times \text { Alcalinos, exibindo a distribuição dos } \\ \text { campos de agrupamento das amostras (Vila Madalena - Área 2). }\end{array}$

Figura V.23: Diagrama geoquímico discriminativo $\mathrm{SiO}_{2} \times \mathrm{TiO}_{2}(\%)$, exibindo a distribuição dos campos de agrupamento das amostras (Vila Madalena - Área 2).

Figura V.24: Imagem em MEV - Aspecto geral da matriz (Vila Madalena - Área 2). 
Figura V.25: Imagem em MEV - Aspecto geral da crosta ferruginosa (Vila Madalena - Área 2).

Figura V.26: Espectro de EDS do ponto 1 da figura V.24, com análise química qualitativa (Vila Madalena - Área 2).

Figura V.27: Espectro de EDS do ponto 2 da figura V.24, com análise química qualitativa (Vila Madalena - Área 2).

Figura V.28: Espectro de EDS do ponto 3 da figura V.24, com análise química qualitativa (Vila Madalena - Área 2).

Figura V.29: Espectro de EDS do ponto 4 da figura V.25, com análise química qualitativa (Vila Madalena - Área 2).

Figura V.30: Espectro de EDS do ponto 5 da figura V.25, com análise química qualitativa (Vila Madalena - Área 2).

Figura V.31: Imagem em MEV de grão metálico constituído principalmente de titânio e ferro. (Vila Madalena - Área 2).

Figura V.32: Espectro de EDS do grão metálico da figura V.31, com análise química qualitativa (Vila Madalena - Área 2).

Figura V.33: Fotomicrografia (LN) de grão de quartzo envolto em plasma goethítico, parcialmente corroído e microfissurado (Pirapora - Área 3).

Figura V.34: Fotomicrografia $(L N)$ de litorelíquia, microfissurada. no contato entre o plasma caulinítico da matriz e o plasma goethítico da crosta (Pirapora Área 3).

Figura V.35: Fotomicrografia $(\mathrm{LN})$ de litorelíquia (fragmento de rocha filítica), cortada por fissura (Pirapora - Área 3).

Figura V.36: Fotomicrografia (LN) de fragmento de couraça ferruginosa dentro do plasma da porção do afloramento sem "dobras" (Pirapora - Área 3).

Figura V.37: Fotomicrografia (LN) contato entre o plasma caolinítico da matriz e o plasma goethítico da crosta ferruginosa (Pirapora - Área 3).

Figura V.38: Fotomicrografia $(\mathrm{LN})$ de fissura, parcialmente preenchida por hidróxidos de ferro (Pirapora - Área 3).

Figura V.39: Fotomicrografia (LP) exibindo região de concentração de plasma caolinítico e litorelíquia circundada borda ferruginosa (Pirapora - Área 3).

Fotomicrografia (LN) Fissuras preenchidas por hidróxidos de ferro (Pirapora -

Figura V.40: Área 3).

Fotomicrografia (LP) de fissura parcialmente preenchida por material caolinítico

Figura V.41: $\quad$ (Pirapora-Área 3).

Figura V.42: Fotomicrografia (LN) exibindo região de contato entre o plasma caolinítico da matriz e o plasma goethítico da crosta (Pirapora - Área 3).

Figura V.43: Fotomicrografia $(\mathrm{LN})$ de estrutura de peenchimento concêntrico indicativa de segregação de hidróxidos de ferro e argila (ferriargilan) (Pirapora - Área 3).

Figura V.44: Fotomicrografia $(\mathrm{LN})$ de estrutura de preenchimento tipo alvéolo ou câmara, circundada por material bandado (Pirapora - Área 3).

Figura V.45: Fotomicrografia $(\mathrm{LN})$ de cavidade preenchida por material argilo-ferruginoso dentro do plasma caolinítico da matriz (Pirapora - Área 3). 
Figura V.46: Fotomicrografia (LN) exibindo região de concentração de plasma goethítico e resto de couraça (Pirapora - Área 3).

Figura V.47: $\quad$ Resultado da análise por DRX para a amostra D1M1 (Pirapora - Área 3). 51

Figura V.48: Resultado da análise por DRX para a amostra D1C1 (Pirapora - Área 3). $\quad 51$

Figura V.49: $\quad$ Resultado da análise por DRX para a amostra D1M6 (Pirapora - Área 3). $\quad 52$

Figura V.50: $\quad$ Resultado da análise por DRX para a amostra D1C6 (Pirapora - Área 3). 52

Figura V.51: Resultado da análise por DRX para amostra $C P$ (porção sem dobras do afloramento de Pirapora - Área 3).

Figura V.52: Comportamento geoquímico dos elementos $\mathrm{Si}, \mathrm{Al}$ e $\mathrm{Fe}$ ao longo dos perfis estudados - (Pirapora - Área 3).

Figura V.53: Diagrama geoquímico discriminativo $\mathrm{Fe}_{2} \mathrm{O}_{3} \times \mathrm{Al}_{2} \mathrm{O}_{3} \times \mathrm{SiO}_{2}$ (\%), exibindo a distribuição dos campos de agrupamento das amostras (Pirapora - Área 3).

Figura V.54: Diagrama geoquímico discriminativo $\mathrm{Fe}_{2} \mathrm{O}_{3} \times \mathrm{SiO}_{2}(\%)$, exibindo a distribuição dos campos de agrupamento das amostras (Pirapora - Área 3).

Figura V.55: Diagrama geoquímico discriminativo $\mathrm{Al}_{2} \mathrm{O}_{3} \times \mathrm{SiO}_{2}(\%)$, exibindo a distribuição dos campos de agrupamento das amostras (Pirapora - Área 3).

Figura V.56: Diagrama geoquímico discriminativo $\left(\mathrm{Al}_{2} \mathrm{O}_{3}+\mathrm{Fe}_{2} \mathrm{O}_{3}\right) \times \mathrm{SiO}_{2}$ (\%), exibindo a distribuição dos campos de agrupamento das amostras (Pirapora - Área 3).

Figura V.57: Diagrama geoquímico discriminativo $\mathrm{SiO}_{2} \times$ (Alcalinos) (\%), exibindo a distribuição dos campos de agrupamento das amostras (Pirapora - Área 3).

Figura V.58: Diagrama geoquímico discriminativo $\mathrm{SiO}_{2} \times \mathrm{TiO}_{2}(\%)$, exibindo a distribuição dos campos de agrupamento das amostras (Pirapora - Área 3).

Figura V.59: Diagrama geoquímico discriminativo $\mathrm{SiO}_{2}(\%) \times \mathrm{Ni}(\mathrm{ppm})$, exibindo a distribuição dos campos de agrupamento das amostras (Pirapora - Área 3).

Imagem em MEV - Aspecto geral do plasma das crostas ferruginosas (Pirapora Área 3).

Figura V.61: Espectro de EDS do ponto 1 da imagem V.60, com análise química qualitativa (Pirapora- Área 3).

Figura V.62: Espectro de EDS do ponto 2 da imagem V.60, com análise química qualitativa (Pirapora- Área 3).

Figura V.63: Espectro de EDS do ponto 3 da imagem V.60, com análise química qualitativa (Pirapora- Área 3).

Figura V.64: Espectro de EDS do ponto 4 da imagem V.60, com análise química qualitativa (Pirapora- Área 3).

Figura V.65: Imagem em MEV - Aspecto geral da matriz (Afloramento de Pirapora - Área 3).

Figura V.66: Espectro de EDS com análise química qualitativa da região da matriz (Figura V.65) (Pirapora - Área 3). 
Figura V.67: Imagem em MEV exibindo concentraçãos de plasma argiloso deferruginizado (nódulos de fuga de hidróxido de ferro) (Pirapora - Área 3).

Figura V.68: Espectro de EDS com análise química pontual qualitativa da região escura no centro da imagem V.67 (Pirapora - Área 3).

Figura V.69: Espectro de EDS com análise química pontual qualitativa da região mais clara da imagem V.67 (Pirapora - Área 3).

Figura V.70: Espectro de EDS com análise química qualitativa do plasma esbranquiçado da porção sem "dobras" do afloramento de Pirapora - Área 3.

Figura V.71: Espectro de EDS com análise química qualitativa do plasma escuro da porção sem "dobras" (Pirapora - Área 3).

Figura V.72: Imagem em MEV - Aspecto geral do plasma da porção sem "dobras" do afloramento de Pirapora - Área 3).

Figura V.73: Espectro de EDS com análise química qualitativa do material que preenche a fissura no ponto 1 da imagem V.72 (Pirapora - Área 3).

Figura V.74: Espectro de EDS com análise quimica qualitativa do material que preenche a fissura no ponto 2 da imagem V.72 (Pirapora - Área 3).

Figura V.75: Espectro de EDS com análise química qualitativa do material que preenche a fissura no ponto 3 da imagem V.72 (Pirapora - Área 3).

Figura V.76: Espectro de EDS com análise química qualitativa do material que preenche a fissura no ponto 4 da imagem V.72 (Pirapora - Área 3).

Figura V1.1: Estereogramas Schimdt Lambert construídos com os dados levantados no afloramento da Vila Madalena (Área-2).

Figura V1.2: Estereograma para dados de fraturas do afloramento (Pirapora - Área 3).

Figura V1.3: Estereograma Schimdt-Lambert para a clivagem tardia pós $S_{3}$ no domínio $E$. (Extraído de Bergmann, 1988) (Pirapora - Área 3).

Estereograma Schimdt Lambert para clivagens de fratura, confeccionados a

Figura V1.4: $\quad$ Estereograma Schimdt Lambert para clivagens de fratura,

Figura V1.5: Diagrama de Schimdt-Lambert (pólos de clivagem de crenulação), dados de Bistrichi (1982) (Pirapora - Área 3).

Figura V1.6: Estereograma de Schimdt-Lambert para os pólos dos flancos de dobras do afloramento (Pirapora - Área 3).

Figura V1.7: Curvas de contorno, guirlanda e eixo construído para Figura V.1.6. (Pirapora Área 3).

Figura V1.8: Estereograma de Schimdt-Lambert para os pólos dos flancos de dobras anticlinais do afloramento (Pirapora - Área 3).

Figura V1.9: Curvas de contorno, guirlanda e eixo construído para Figura V.1. 8. (Pirapora Área 3).

Figura V1.10: Estereograma de Schimdt-Lambert para os pólos dos flancos de dobras sinclinais (Pirapora - Área 3).

Figura V1.11: Curvas de contorno construídas para Figura V.1.10 (Pirapora - Área 3).

Figura V1.12: Estereograma Schimdt-Lambert para os pólos dos flancos de dobras contidas entre FA e D1, especificados no croqui (Figura III.3) (Pirapora - Área 3). 
Figura V1.13: Curvas de contorno, guirlanda e eixo construído para Figura V.1.12. (Pirapora Área 3).

Figura V1.14: Estereograma Schimdt-Lambert para os pólos dos flancos de dobras anticlinais, contidas na área delimitada por FA e D1 (Figura III.3) (Pirapora - Área 3).

Figura V1.15: Curvas de contorno, guirianda e eixo construído para Figura V.1.14. (Pirapora Área 3).

Figura VI.1: Esquema evolutivo das crostas deformadas de Pirapora do Bom Jesus, baseado na proposta de origem geoquímica para estas estruturas

\section{TABELAS}

Tabela V.1: Resultados das análises químicas totais por ICP-AES para as amostras coletadas nos perfis da Dutra (Área 1).

Tabela V.2: $\quad$ Resultados da análise mineralógica semi quantitativa dos minerais pesados para a amostra das crostas (Vila Madalena - Área - 2).

Tabela V.3:

Resultados da análise mineralógica semi quantitativa dos minerais pesados para a amostra da matriz (Vila Madalena - Area - 2).

Resultados das análises químicas totais para as amostras coletadas nos

Tabela V.4: $\quad$ perfis do Afloramento da Vila Madalena (Área-2).

Tabela V.5: Resultados da análise mineralógica semi-quantitativa dos minerais pesados para a amostra DIM1, Pirapora (Ärea - 3).

Tabela V.6:

Resultados da análise mineralógica semi-quantitativa dos minerais pesados para a amostra DIC1, Pirapora (Área - 3).

Tabela V.7:

Resultados da análise mineralógica semi-quantitativa dos minerais pesados para a amostra DIM3, Pirapora (Ärea - 3).

Tabela V.8:

Resultados da análise mineralógica semi-quantitativa dos minerais pesados para a amostra DIC3, Pirapora (Área - 3).

Tabela V.9:

Resultados da análise mineralógica semi-quantitativa dos minerais pesados para a amostra DIM6, Pirapora (Área - 3).

Tabela V.10: Resultados da análise mineralógica semi-quantitativa dos minerais pesados para a amostra DIC6, Pirapora (Ärea - 3).

Tabela V.11:

Resultados da análise mineralógica semi-quantitativa dos minerais pesados para a amostra DIC7, Pirapora (Área - 3).

Resultados da análise mineralógica semi-quantitativa dos minerais pesados

Tabela V.12: $\quad$ para a amostra da porção sem "dobras", Pirapora (Área - 3).

Tabela V.13: Resultados das análises químicas totais para as amostras coletadas nos perfis do Afloramento de Pirapora (Área - 3).

Tabela V1.1: Medidas Estruturais das Dobras Levantadas em Campo. (Vila Madalena Área 2).

Tabela V.1.2: Medidas das dobras do afloramento de Pirapora (Área - 3). 


\section{AGRADECIMENTOS}

Gostaria de expressar meus agradecimentos:

Ao Prof. Dr. Joel B. Sígolo, pela orientação e amizade;

À CAPES, pelo financiamento da bolsa de estudo do mestrando;

À FAPESP, pelo financiamento do projeto através do Processo $n^{0}$ 97/007646;

Agradeço às pessoas que, me deram apoio durante todo o periodo de pesquisa:

Ao Samuel, pelo apoio nas etapas de campo e na preparação das amostras;

À bolsista de Iniciação Cientifica Daniela Goulios, pelo apoio nos trabalhos de campo e nas análises estruturais;

À Verônica, do Laboratorio de Análises Mineralógicas, do IG-USP, pelo apoio na preparação das amostras indeformadas;

À Sandra, do Laboratório de Química e Plasma ICP-AES do GMG do IG-USP, pelas análise químicas;

Ao Flávio, do $D R X$, pelas análises, pela orientação na preparação das amostras e na interpretação dos resultados;

Ao Isaac, do Laboratório de Microscopia Eletrônica de Varredura do GSA do IGUSP, pelas análises em MEVIEDS e pela orientação durante esta etapa;

Ao José Carlos B. de Assunção, pelas análises de Minerais Pesados ;

Ao colega Mauro Geraldes, pela ajuda na elaboração e revisão do abstract;

À Patrícia, pela revisão do texto e pelo apoio e paciência durante todo o trabalho;

À Ana Paula e Magali, da Seção de Pós-Graduação do IG-USP ;

Aos amigos da Pós-Graduação que, de uma forma ou de outra, me ajudaram e pela força e amizade durante todo o trabalho. 


\section{RESUMO}

São descritos e caracterizados neste trabalho dobramentos em crostas ferruginosas, tomando-se para estudo três áreas distintas. Duas inseridas no contexto geológico da Bacia Terciária de São Paulo. Uma localizada na Rodovia Presidente Dutra, próximo ao município de Santa Isabel, SP e outra no bairro Vila Madalena, na cidade de São Paulo, SP. A terceira, encontra-se na região de Pirapora do Bom Jesus, SP, no contexto geológico do Grupo São Roque.

Este estudo objetivou verificar a gênese dos dobramentos nas crostas ferruginosas, baseando-se nas hipóteses de origem tectônica e/ou geoquímica. Foram empregadas análise micromorfológica de seções delgadas confeccionadas a partir de 50 amostras indeformadas, análises químicas totais em 46 amostras, e pontuais em MEV/EDS em 10 seções delgadas, Difratometria de Raio $X$ (DRX) em 7 amostras da fração argilosa e separação de minerais pesados em 10 amostras nas frações 16,35100 e 200 mesh. As amostras foram coletadas a partir de 11 perfis locados nos afloramentos das diferentes áreas de estudo.

Associadas as análises acima mencionadas, efetuou-se levantamento estrutural e análise comparativa entre feiçóes estruturais regionais e as dobras nas crostas ferruginosas encontradas. Através da aplicação de diagramas de Schimdt-Lambert, foram analisados os parâmetros geométricos, morfológicos e as orientações preferenciais das dobras e fraturas.

As crostas ferruginosas dos afloramentos da Dutra, da Vila Madalena e de Pirapora do Bom Jesus, apresentam organização textural, composição química e mineral semelhantes, embora se encontrem encaixadas em litologias diferentes e inseridas em contextos geológicos distintos. São constituídas basicamente por óxidos e hidróxidos de ferro (domínio da goethita) e quartzo. Foi possivel reconhecer nestes materiais a origem e o desenvolvimento de produtos secundários como nodulações e feições de preenchimento de poros e fissuras, principalmente por hidróxidos de ferro e secundariamente por hidróxidos de alumínio e argilas.

Os sedimentos encaixantes dos afloramentos da Dutra e da Vila Madalena são constituídos por material alterado, argiloso e areno-argiloso respectivamente. As análises mineralógicas em DRX e separação de minerais pesados, indicaram que o sedimento do afloramento da Vila Madalena, é constituído predominantemente por quartzo e caolinita. Biotita, ilmenita, turmalina, zircão e rutilo ocorrem secundariamente nestes materiais.

No afloramento de Pirapora a litologia é caracterizada por conjugação de argilas avermelhadas e amaleladas fornecendo aspecto de argila variegada para o sedimento encaixante. As análises mineralógicas em DRX indicaram que o sedimento é constituído predominantemente por argilas ferruginosas, argilas do grupo da caolinita, subordinadamente quartzo e secundariamente biotita gibbsita e ilmenita. Ocorrem também litorelíquias constituídas por fragmentos de rocha filítica do 
Grupo São Roque. Na separação de minerais pesados identificou-se turmalina, zircão, rutilo e goethita na forma de agregados.

As crostas ferruginosas dobradas são de origem genuinamente geoquímica, comprovada pelos diferentes diagramas geoquímicos discriminativos que exibem trends de evolução geoquímica partindo do sedimento encaixante até as crostas ferruginosas. Estas formadas a partir de processos de remobilização e concentração de óxidos e hidróxidos de ferro, promovidos pelo deslocamento descendente do fluxo d'água e oscilações do nível hidrostático $(\mathrm{NH})$, relacionadas a variações climáticas sazonais e movimentações ascendentes do relevo (no caso do afloramento de Pirapora).

A constituição mineral, a organização textural e a composição química total e pontual das crostas ferruginosas das três áreas estudadas, indicam que estas se originaram a partir da cimentação de óxidos e hidróxidos de ferro remobilizados do próprio sedimento encaixante. A diferença entre esses materiais reflete-se apenas no empobrecimento em $\mathrm{Fe}_{2} \mathrm{O}_{3}$ e enriquecimento em $\mathrm{SiO}_{2}, \mathrm{Al}_{2} \mathrm{O}_{3}$ e elementos alcalinos no sedimento, contrariamente ao observado nas crostas ferruginosas.

A origem das crostas ferruginosas pseudo-dobradas, não está diretamente relacionada a processos tectônicos. Não foi possivel estabelecer correlação entre os dados estruturais extraídos dos afloramentos estudados com padrões de dobras de origem tectônica, nem com padrões de deformação regionais das titologias circundantes.

No afloramento de Pirapora, a instalação de fraturas por provável reativação tectônica (Quaternária) de sistemas de falhas regionais, teria condicionado o fluxo d'água, permitindo que óxidos e hidróxidos de ferro se precipitassem no interior das mesmas. Estruturas tipo "pena" se formaram pela precipitação de compostos de ferro, obliquamente às fraturas. O conjunto formado pela união dessas "penas", delineia a forma e a feição de crostas ferruginosas dobradas apresentada neste afloramento. 


\begin{abstract}
Folds in iron crusts are described and characterized in this work, for three different study areas. Two inserted in the Tertiary São Paulo Basin, the first located in the Highway President Dutra, near the municipal district of Santa Isabel-SP; the second in Vila Madalena, São Paulo- SP; and the third located in Pirapora do Bom Jesus-SP, in the geologic setting of the São Roque Group.

The objective of this study was to verify the folded iron crust genesis, checking the hypotheses of origin by tectonic or geochemistry process. The following analysis were done: 50 samples of tin sections; 46 whole rock chemical analysis; 10 tin sections were used for punctual analysis in Scanning Electronic Microscopy (SEM-EDS); 7 samples in X-Ray Difratometry (XRD) of clay fractions; and heavy minerals separation in 10 samples in the fractions 16,35100 and 200 mesh. The samples were collected from 11 profiles located in the outcrops of the different studied areas.
\end{abstract}

In parallel to the analysis above mentioned, it was made comparative structural analysis between regional structural and the folded iron crusts patterns. Through the application of Schimdt-Lambert diagrams, the geometric, morphologic parameters and the preferential orientations of the folds and fractures were defined.

The iron crusts outcrops of Dutra, Vila Madalena and Pirapora do Bom Jesus, present textural organization, similar chemical and mineral composition, although they are located in different rocks and in different geologic setting. They are constituted basically by iron oxides and hydroxides (goethite) and quartz. It was possible to recognize the origin and the secondary development of these materials as nodules and pore and fissures filling features, mainly by iron hydroxides and secondarily by aluminum hydroxides and clays.

The sedimentary host-rocks in Dutra and Vila Madalena outcrops are comprised by altered material, clay and sand + clay, respectively. The mineralogical analyses in XRD and separation of heavy minerals, indicated the sedimentary rocks of Vila Madalena outcrop is constituted predominantly by quartz and caolinita. Biotite, ilmenite, turmaline, zircon and rutile occur secondarily.

The litology in Pirapora outcrop is characterized by red and yellow clays hosted by sedimentary rocks. The mineralogical analyses in XRD indicated the sedimentary host-rocks are constituted mainly by iron clays, caolinite group clays, and secondarily quartz, biotite, gibbsite and ilmenite. They also occur constituted by lithorelics fragments rocks from São Roque Group. In the heavy minerals separation were identified turmaline, zircon, rutile and goethite.

The iron crusts have geochemical origin, checked by the geochemistry diagrams which show trends of geochemical evolution linking sedimentary host-rocks and iron crusts. These iron crusts were formed from remobilization and concentration processes of iron oxides and 
hydroxides, origined by the descending meteoric water and groundwater level oscillation, related to seasonal climatic variations and relief ascending movements (in Pirapora case).

The mineral constitution, the textural organization and the total and punctual chemical iron crusts composition in the three studied areas, indicated they originated from the iron oxides and hydroxides precipitation from sedimentary host-rocks. The difference between both material is only result of depletion in $\mathrm{Fe} 2 \mathrm{O} 3$ and enhance in $\mathrm{SiO} 2, \mathrm{Al} 2 \mathrm{O} 3$ and alkaline elements in the sedimentary rocks, contrarily to the observed in the iron crusts.

The origin of iron crusts pseudo-folded is not directly related to tectonic processes. It was not possible to establish correlation between the studied areas structural data with tectonic fold or regional deformation patterns.

Fractures in Pirapora outcrop are due regional lineaments tectonic reactivation (Quaternary), which were conditioned by water flow, allowing iron oxides and hydroxides precipitation inside the fractures. Grieves-type structures were formed by iron oxides and hydroxides precipitation oblique to the fractures. The group formed by the juxtaposition of those grieves-type structures delineates the pattern and feature of folded iron crusts observed in this outcrop. 


\section{1 - INTRODUÇÃO}

Três áreas distintas com dobramentos em crostas ferruginosas são descritas neste trabalho. Parte destas encontram-se encaixadas em sedimentos da Bacia Terciária de São Paulo. Uma, localizada na Rodovia Presidente Dutra próximo ao Município de Santa Isabel, e outra no bairro Vila Madalena, na cidade de São Paulo; ambas encaixadas em sedimentos argilo-arenosos da Formação São Paulo.

O terceiro local que exibe tais estruturas encontra-se na região de Pirapora do Bom Jesus - SP, encaixadas em rochas do Grupo São Roque.

A ocorrência destas "dobras" em crostas ferruginosas, durante muitos anos tem sido explicada sob diferentes hipóteses quanto a sua origem. Por um lado, há propostas de interpretação sugerindo origem tectônica (proveniente de deformações modernas Quaternárias/Terciárias). Por outro, há quem as interprete como sendo de origem genuinamente geoquímica, através de processos de remobilização e concentração de hidróxidos de ferro diante das oscilações do lençol freático.

O estudo dessas estruturas e sua análise científica, na tentativa de confirmar uma ou outra hipótese acima levantada, tornou-se objeto desta dissertação.

A gênese destas estruturas representa um fenômeno geológico que pode ser explicado a luz de uma investigação fundamentada na geologia estrutural e na geoquímica de superfície.

O esclarecimento dessas feições pode ser obtido através de estudo comparativo do comportamento químico e geoquímico dos materiais das crostas e das rochas associadas.

Por outro lado, a confirmação de uma origem tectônica para estas estruturas, pode ser definida com a aplicação de análise estrutural dos parâmetros morfológicos (direção preferencial de flancos, charneiras, planos axiais, etc.) e comparação com feições estruturais conhecidas na literatura. 


\section{Objetivos}

O objetivo deste trabalho é verificar a origem de dobramentos em crostas ferruginosas, com base em hipóteses tectônica e/ou geoquímica. Para tanto, foi utilizado levantamento estrutural convencional e análise geoquímica dos diferentes materiais associados, cuja base compreende análises químicas totais $e$ análises químicas pontuais qualitativas e semi - quantitativas.

\section{Proposta de investigação}

Para a realização dos objetivos propostos foram empregadas análises micromorfológica, químicas (totais e pontuais) e mineralógicas (Difração de Raios- $X$ (DRX) e separação de minerais pesados), associadas a análise estrutural comparativa entre as feições regionais e a morfologia das dobras encontradas nas crostas ferruginosas (flancos, charneiras, etc.).

Havendo origem estrutural/tectônica para estas dobras, certamente serão obtidos padrões estruturais nos estereogramas de análise estrutural destas, que configurem processos de deformação mecânica. Caso possuam origem geoquímica (proveniente da mobilidade de hidróxidos de ferro no interior da litologia), os estereogramas de análise estrutural, muito provavelmente não exibirão padrões claros de comportamento estrutural.

Caso a origem seja diferente da acima apontada, o emprego de diagramas de discriminação geoquímica poderá demonstrar, através de "trends" de evolução de materiais parentais e das crostas ferruginosas, uma origem evolutiva provinda de processos intempéricos e da transferência dos compostos secundários durante a alteração da própria rocha portadora das estruturas.

Feições texturais e mineralógicas como porosidade, composição mineral, assembléias minerais primárias e secundárias e distribuição de minerais pesados, demonstrarão claramente que os materiais exibem uma origem geoquímica comum. 


\section{DEFORMAÇÕES DE ORIGEM ATECTÔNICA}

Baseado na proposta de interpretação de origem atectônica para as deformações encontradas nas crostas ferruginosas estudadas, torna-se pertinente que alguns dos principais processos geológicos formadores dessas estruturas sejam aqui abordados.

As deformações em rochas formam-se graças a esforços ocasionados por diferentes fenômenos geológicos, deformando a rocha original e proporcionando assim uma morfologia secundária nestas e, em alguns casos, até modificações de ordem química (transformações minerais) no material original. Quando relacionadas essas deformações a fenômenos geológicos, há que se creditar a origem das forças modificadoras dos materiais às diversas possibilidades de ocorrência, ou seja, desenvolvimento e ativação de falhas, diferentes movimentos tectônicos ocasionados pela movimentação dos continentes, onde esforços orientados ocasionam mudanças no comportamento original das estruturas das rochas.

Os processos de origem atectônica não estão relacionados à deformações tectônicas que envolvem propagação de forças internas da terra e afetam niveis profundos da crosta, e sim por processos superficiais como intemperismo, erosão e deposição de sedimentos. Estas deformações apresentam-se como dobras e falhas, e são em geral de menores dimensões podendo ou não exibir correlação com a orientação do arcabouço tectônico regional.

As deformações atectônicas podem ser originadas, por diferentes processos, sendo os principais, descritos a seguir de forma resumida:

\section{Compactação Diferencial}

Quando a compactação por gravidade atua sobre sedimentos homogêneos de considerável extensão lateral, depositados sobre uma superfície plana, quase horizontal, os únicos efeitos que poderão ser notados serão a redução em espessura $\Theta$ porosidade, e aumento de sua densidade. 
No entanto, se os sedimentos se acumularem em uma superfície que apresente relevo acentuado ou se houver mudança lateral no caráter dos sedimentos, poderá ocorrer sua compactação diferencial.

Por exemplo, quando elevações ou colinas constituidas de uma rocha mais antiga (paleocolina), mais resistente à erosão é recoberta por sedimentos mais jovens, os estratos sedimentares, pelo efeito do mergulho original e compactação, amoldam-se à elevação, formando um anticlinal amplo, de origem atectônica. Após o recobrimento total da paleocolina, a sedimentação adicional aumentará a intensidade do dobramento e do fechamento acima da paleocolina e falhas normais podem também se desenvolver.

\section{Escorregamentos e Deslizamentos Subaquosos}

As deformações originadas por escorregamento são resultantes de deslocamento horizontal de sedimentos inconsolidados, principalmente por ação da gravidade e geralmente exibem evidências de extensos movimentos laterais. Elas são associadas a falhamentos penecontemporâneos e exibem planos de deslizamento com pequeno ângulo de mergulho. Feições desse tipo são comuns em sedimentos glacio-lacustres e flúvio - glaciais (Suguio, 1980).

As estruturas de escorregamento associam-se, em geral, à rápida deposição de sedimentos lamosos em declives mais ou menos acentuados. $O$ escorregamento de uma massa sedimentar pode resultar no rompimento $e$ transporte de camadas sedimentares, produzindo mistura caótica de sedimentos. Em outros casos, o escorregamento pode produzir camadas contorcidas sem ou com pequeno deslocamento (Potter e Pettijohn, 1963). O movimento lateral pode ser iniciado por terremotos, tempestades e muitas vezes pelo próprio peso dos sedimentos. Essas condições são frequêntemente satisfeitas em frentes deltaicas em bacias de subsidência ativa.

Mckee et al. (1971) e Bigarella (1972), descreveram feições de deformação subaérea produzidas em dunas eólicas. Processos de avalanche na face abrupta das dunas produzem camadas contorcidas com falhas, dobras e arqueamentos. 
Falhas e dobras originadas por escorregamentos e deslizamentos podem ser diferenciadas das ligadas a fenômenos tectônicos, pois os movimentos de deformação penecontemporânea afetam apenas um determinado horizonte do pacote sedimentar. Desse modo, os horizontes deformados por estes processos situam-se entre camadas não perturbadas.

\section{Deformações Originadas em Materiais Altamente Plásticos e/ou por Mudanças de Volume}

As deformações em materiais ainda plásticos envolvem movimentos verticais e são originadas geralmente em depósitos sedimentares constituídos por areias finas e siltes laminados com leitos argilosos (ritmitos). Estes sedimentos podem exibir estruturas de deformação penecontemporânea denominadas laminação convoluta.

A correlação dos eixos de dobras com as cristas de marcas onduladas e a presença de superfícies de escavação intra-estratais sugerem que o movimento foi virtualmente sincrônico à deposição. A laminação convoluta deve ser originada por desidratação de sedimentos ajudada por esforços de cisalhamento desenvolvidos pela própria corrente de turbidez (Davies, 1965 ; Anketell et al.,1970).

\section{Estruturas Formadas por Alteração Intempérica das Rochas}

Examinando-se as rochas em profundidade através de galerias de minas, pode-se observar que estas não apresentam deformações como na superfície, evidenciando a alteração supérgena como elemento gerador de algumas feições como juntas, fraturas e esfoliação esferoidal.

As juntas e fraturas podem se desenvolver durante processos de cristalização ou hidratação, nos quais a forma e o tamanho de alguns minerais são significativamente modificados, podendo romper até blocos de rocha, devido à expansão destes minerais.

$\mathrm{Na}$ esfoliação esferoidal, matacões desenvolvem "cascas" superficiais como resultado da expansão superficial devido ao crescimento de minerais hidratados/durante o intemperismo químico. 


\section{3. ÁREAS ESTUDADAS}

\section{Localização das Áreas Estudadas}

Foram estudados nesta dissertação três afloramentos onde ocorrem estruturas dobradas formadas por crostas ferruginosas. Na Rodovia Presidente Dutra (sentido Rio - São Paulo), próximo ao município de Santa Isabel - SP (Área -1), ocorrem dois locais com dobramentos em crostas ferruginosas, um no Km 211,5 e outro no Km 214,5. O segundo afloramento localiza-se na Rua Girassol, bairro de Vila Madalena, na cidade de São Paulo -SP (Área - 2) (Figura III.1).

O terceiro afloramento localiza-se no Km 53 da Estrada dos Romeiros (SP-312) entre os municípios de Santana do Parnaíba e Pirapora do Bom Jesus -SP (Área - 3), a cerca de $50 \mathrm{Km}$ da capital. O acesso a este afloramento é realizado pela Rodovia Presidente Castelo Branco até o município de Barueri - SP e pela Estrada dos Romeiros (Figura III.1).

MAPA DE LOCALIZAÇÃO DAS ÁREAS ESTUDADAS

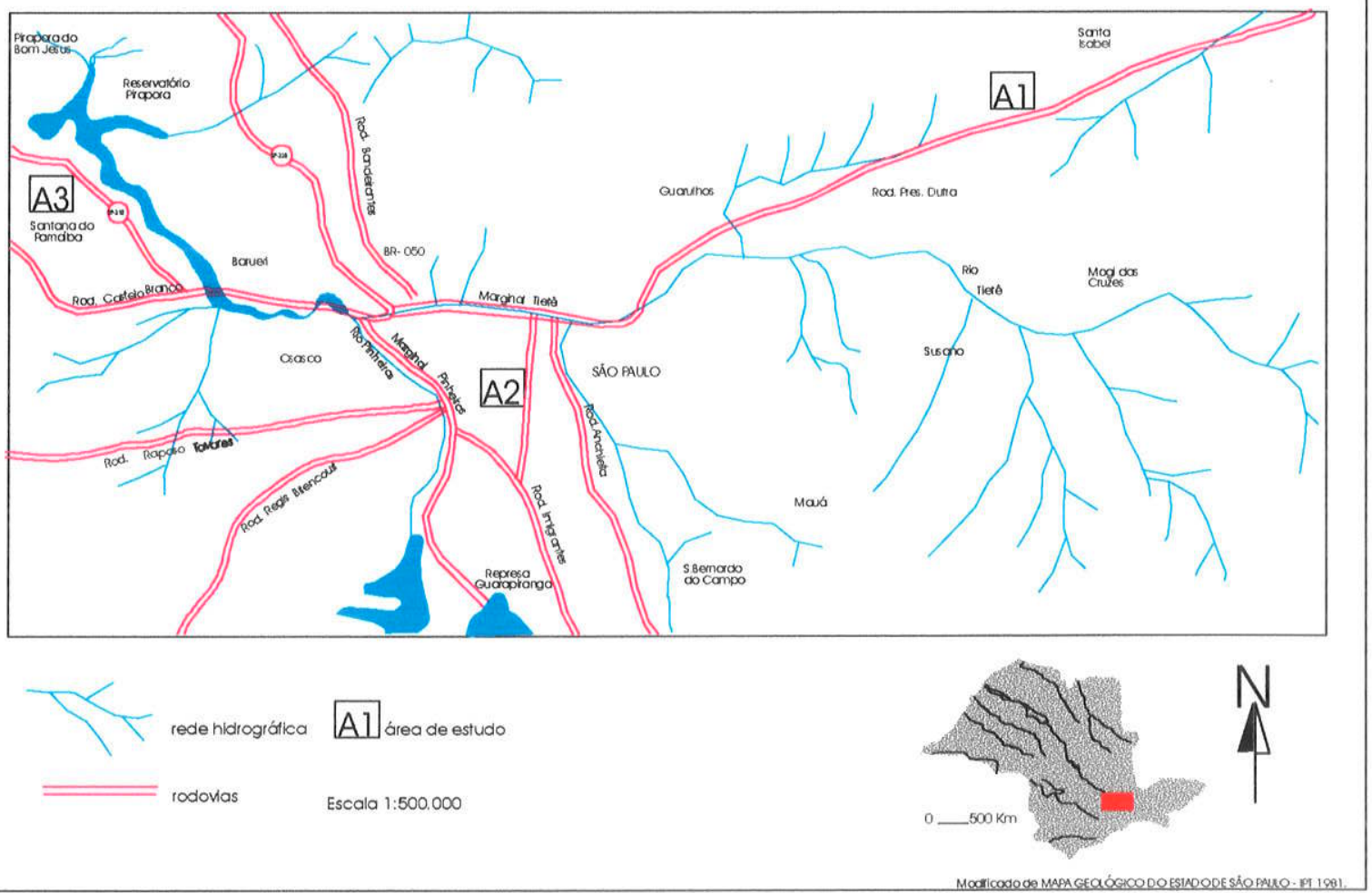

Figura III .1 - Mapa de Localização das Áreas Estudadas 


\section{Geologia Regional}

\section{Bacia de São Paulo}

Os afloramentos da Rodovia Presidente Dutra em Santa Isabel - SP (Área -1) e da Rua Girassol na Vila Madalena - SP (Área - 2) encontram-se inseridos em sedimentos da Formação São Paulo, Bacia Terciária de São Paulo (Figura III.2).

Os sedimentos da Bacia Terciária de São Paulo distribuem-se por uma área aproximadamente ovalada com cerca de $1.000 \mathrm{Km}^{2}$. Esta exibe a norte, borda retilínea, marcada pelo sistema de falhas Taxaquara-Jaguari. A sul, apresenta contatos irregulares com o embasamento Pré-cambriano. Seus eixos maior $(60 \mathrm{Km})$ e menor $(25 \mathrm{Km})$, dispõem-se respectivamente entre as localidades de Arujá e Interlagos, Santo André e Santana, SP. São ainda observadas ramificações a sul, de Interlagos para Bororé e Cipó, e a leste, de Itaquaquecetuba para Mogi das Cruzes e Palmeiras, SP (Takaiya, 1997).

A Bacia de São Paulo insere-se no contexto do Sistema de Rifts Continentais da Serra do Mar, definido por Almeida (1976). Ricomini (1989) modificou este termo para Rift Continental do Sudeste do Brasil para designar a feição tectônica desenvolvida como estreita faixa alongada e deprimida de direção ENE, com extensão de aproximadamente $800 \mathrm{Km}$, englobando as bacias de Curitiba, São Paulo, Taubaté, Resende, Volta Redonda, Itaboraí e Barra de São João, e os grabens de Sete Barras e da Guanabara.

Riccomini (1989), elaborou quadro relacionando os eventos tectônicos $\theta$ estabeleceu coluna estratigráfica revisada, onde no Paleógeno (Eoceno - Oligoceno) teria ocorrido a formação da depressão original, um hemi-graben contínuo na porção compreendida pelas atuais bacias de São Paulo, Taubaté, Resende e Volta Redonda, fruto de esforços trativos de direção NNW-SSE. No Neógeno, possivelmente Mioceno, se iniciaria o tectonismo deformador, associado a um binário transcorrente sinistral de direção $\mathrm{E}-\mathrm{W}$, responsável pela geração do alto estrutural de Arujá separando as drenagens dos rios Tietê e Paraíba do Sul, do alto estrutural de Queluz, e de bacias pull-apart. 


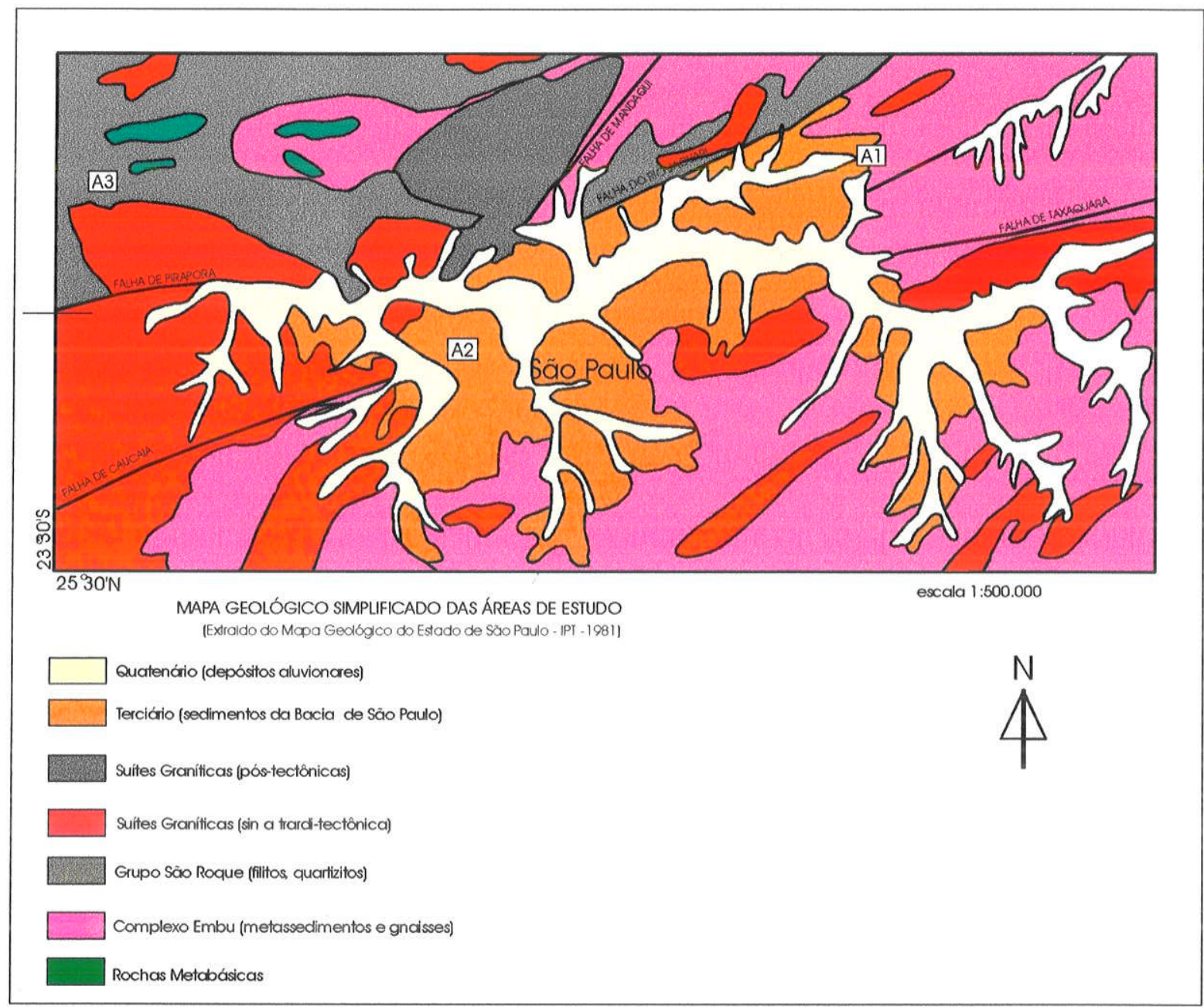

Figura III. 2 - Mapa Geológico Regional (simplificado do Mapa Geológico do Estado de São Paulo), escala 1:500.000, 1984 - IPT-PRÓ-MINÉRIO. 


\section{Grupo São Roque}

O afloramento de Pirapora (Área - 3) está inserido nos domínios do Grupo São Roque (Figura III.2).

Segundo Bistrichi (1982), as litologias na região de Pirapora do Bom Jesus, se constituem de rochas pré-cambrianas, além de depósitos cenozóicos restritos. O Précambriano é representado por metamorfitos do Grupo São Roque e rochas granitóides associadas, relacionadas ao desenvolvimento do Ciclo Brasiliano. O Grupo São Roque exibe como rochas principais, quartzitos, diferentes tipos de xistos, filitos, calcários e anfibolitos. Estas rochas afloram continuamente na forma de uma faixa com pouco mais de $180 \mathrm{Km}$ de comprimento e $50 \mathrm{Km}$ de largura, terminando em cunha no sentido nordeste da região, até as proximidades de Monteiro Lobato - SP.

Bergmann (1988), apresenta série de dados e estudos relativos a sequência vulcanosedimentar do Grupo São Roque nas proximidades da área de estudo. Através do levantamento de perfis estruturais e o emprego de estruturas geopetálicas (indicadoras de topo e base), a autora propõe três unidades litoestratigráficas formais compondo o Grupo São Roque: Formação Pirapora, basal e composta predominantemente por rochas metavulcânicas / sub-vulcânicas, e rochas piroclásticas subordinadas, com um membro carbonático: Formação Estrada dos Romeiros, acima na estratigrafia, em contato transicional com membro arenoso na base e membro pelítico no topo em contato brusco a transicional com a Formação Boturuna sobreposta, apresentando membros ora vulcânicos, ora arenosos.

Em seu trabalho, Bergmann (1988), tece considerações à paleogeografia e ao ambiente de deposição da sequência São Roque, associando-a à calhas rasas, do tipo rift intracontinental, com atividade vulcânica nos primeiros estágios de sua evolução.

Em relação a geologia estrutural, Bistrichi (1982), identificou três fases de dobramentos, sendo as duas primeiras bem caracterizadas, enquanto a terceira está relacionada a dobramentos localizados. A fase principal de dobramento foi a segunda, e é responsável pela estruturação regional, inclusive pelo estabelecimento da macroestrutura sinclinorial de Pirapora. 
Movimentações teriam afetado tanto os metamorfitos como as rochas granitóides gerando rochas cataclásticas de diversos tipos, desenvolvendo-se logo após a fase principal de dobramentos até o final dos últimos eventos do Ciclo Brasiliano (Bistrichi, 1982).

Bergmann (1988), também ressalta em seu trabaiho a grande estrutura sinclinorial (Sinclinório de Pirapora), compreendendo rochas metamórficas do fácies xisto verde e identifica cinco fases de dobramentos, três sin a tardi-metamórficas e duas pósmetamórficas.

Uma articulação de dobras anticlinais recumbentes da segunda fase controla a geometria dos contatos entre as unidades litoestratigráficas. A terceira fase de dobramentos é tardia ao metamorfismo, com dobramentos apresentando traços axiais e eixos orientados quase sempre de $E$ para $W$ com mergulhos para $N E$ e $W$, desenvolvendo clivagem axial espaçada. Duas fases pós-metamórficas a fase do Sinclinório de Pirapora, com eixos a N60-70E, e outra fase tardia em torno de NSNNW, não apresentando hierarquias (Bergmann, 1988).

Neste estudo será adotada a proposta de Bistrichi (1982), para a definição das litologias. Para as análises estruturais comparativas foram utilizados os dados levantados nos trabalhos de Bistrichi (1982) e de Bergmann (1988), como direções das falhas, fraturas e lineações, além dos parâmetros morfométricos das dobras.

Quanto as idades, o grupo São Roque exibe contato com o grupo Serra do Itaberaba, através de falhas transcorrentes e/ou falhas de baixo ângulo (Juliani et al., 1986).

Alguns autores consideram o grupo Serra de Itaberaba como Proterozóico Médio a Inferior, e o Grupo São Roque como de idade Brasiliana (Juliani e Beljavsks, 1995). Outros, consideram estes dois grupos como um único, com a sedimentação iniciandose a pouco mais de 1,8 Ga, acompanhada de diferentes deformações, incluindo dois prováveis eventos metamórfico granitogênico ocorridos no Proterozóico Superior (Tassinari et al.,1988; Sadowisk e Tassinari, 1988; Dantas, 1990; Bergmann, 1988). 


\section{Geologia Local}

Afloramentos da Dutra (Área - 1) e da Vila Madalena (Área - 2)

As crostas ferruginosas dobradas da Rodovia Presidente Dutra (Área - 1), e no bairro de Vila Madalena (Área - 2) em São Paulo, encontram-se encaixadas em rochas da Formação São Paulo, Bacia de São Paulo.

A Formação São Paulo exibe sedimentos fluviais, incluindo, argilitos, siltitos, arenitos argilosos finos e, subordinadamente, arenitos grossos, cascalhos, conglomerados $\theta$ leitos restritos de argilas orgânicas (IPT/Pró-Minério, 1981). Estes depósitos são constituídos por sedimentos pelíticos de planície de inundação, de coloração arroxeada a amarelada, associados lateralmente a espessos pacotes de areias médias a grossa com matriz argilosa, depositados em condições de maior energia, atribuídas a um subambiente de barra de pontal (Takiya, 1997).

Os sedimentos da Formação São Paulo encontram-se comumente associados a crostas ferruginosas (Suguio e Barbour, 1969), sustentando altas colinas, como verificado no espigão central situado na região da Av. Paulista e no bairro do Sumaré na cidade de São Paulo (Takiya, 1991).

Washburne (1930), descreveu equivocamente, as crostas limoníticas existentes a 22 Km de São Paulo, na Rodovia Presidente Dutra, como dobras em anticlinais pela configuração sugestiva dessas crostas em forma de pseudodobras.

Segundo Sígolo e Ohnuma (1996), os horizontes ferruginosos encontrados na Bacia de São Paulo, teriam sido gerados a partir da alternância de fases climáticas mais áridas para mais úmidas, acompanhadas de soerguimento que conduziu o lençol freático a níveis mais profundos em relação aos sedimentos da bacia. Este rebaixamento do lençol promoveu a dissolução de minerais contendo ferro, associados principalmente a sedimentos argilo-ferruginosos. Com a deferruginização destes níveis, o ferro solubilizado deslocou-se e precipitou-se em zonas específicas, onde a armadilha de fixação era dada por uma camada superior de sedimentos permeável e porosa (horizontes areno-argilosos), em contato com uma camada inferior impermeável (horizontes argilosos). 
As crostas ferruginosas dobradas da região de Pirapora do Bom Jesus (Área -3) encontram-se encaixadas em rochas do Grupo São Roque. No local estudado, a rocha é caracterizada por sedimento argiloso, alterado, com nódulos argilosos esbranquiçados e fragmentos de quartzo e de rocha filítica, conferindo aspecto de brecha sedimentar a rocha.

$\mathrm{Na}$ região, predominam metassedimentos rítmicos, quase sempre total ou parcialmente alterados, assumindo tons róseo, amarelados e vermelhos. Há uma alternância de leitos quartzosos, com espessuras variando de milímetros à centímetros.

Estruturas primárias são freqüentes no Grupo São Roque, definindo-se pelos menos três diferentes direções de foliações. Estas, em alguns pontos, atingem crenulações como as observadas no $\mathrm{Km} 44$ da Estrada dos Romeiros, sentido Santana de Paraíba à Pirapora (Bistrichi, 1982).

\section{Descrição dos Afloramentos}

Afloramentos da Rodovia Presidente Dutra - Santa Isabel - SP (Área - 1)

A litologia do afloramento do $\mathrm{Km} \mathrm{214,5}$ é compreendida por sedimento argiloso, de coloração variada, constituído por porções esbranquiçadas caoliníticas e porções avermelhadas, conferindo aspecto de argila mosqueada a este sedimento. Ocorrem inclusos fragmentos sub-arredondados e seixos de quartzo leitoso. Em alguns pontos, formam-se "Anéis de Liesegang" e concreções avermelhadas. (Figuras III.3 e III.4).

Do outro lado da rodovia, ocorre um único horizonte ferruginoso contínuo, avermelhado e ligeiramente endurecido, constituído por material mais arenoso e couraça ferruginosa totalmente fragmentada, encaixados no sedimento argiloso descrito acima. (Figuras III.5 e III.6). 


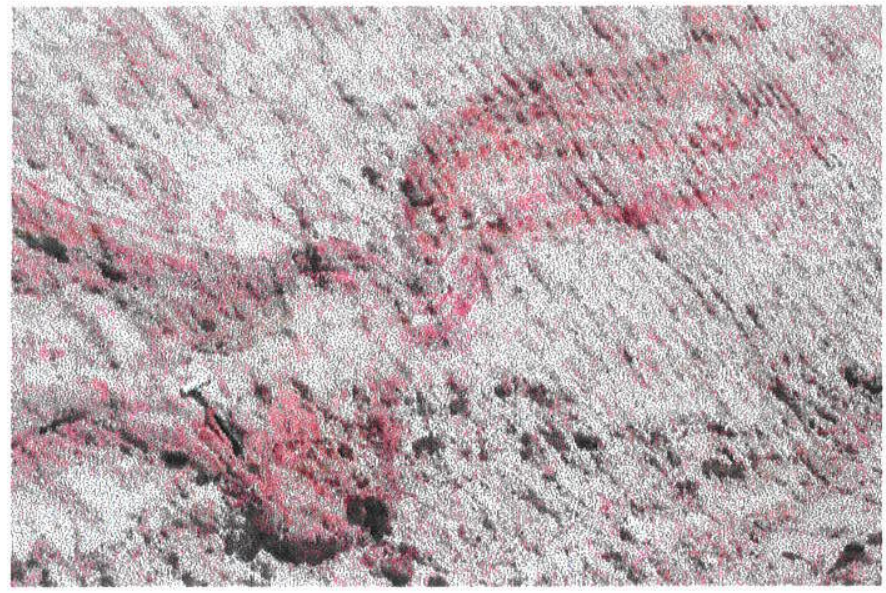

Figura III.3 - Fotografia exibindo o afloramento do Km 214,5 da Rodovia Presidente Dutra (sentido Rio - São Paulo).

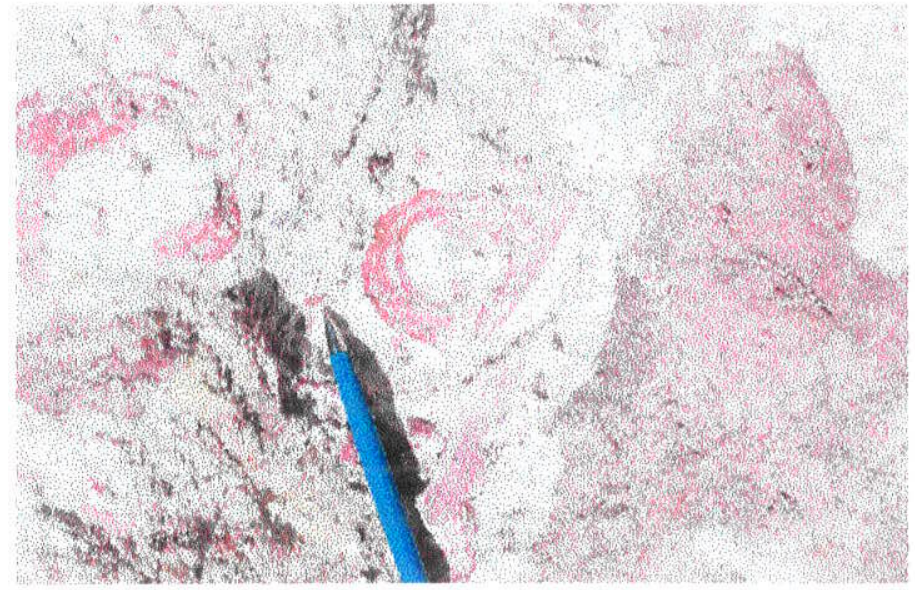

Figura III.4 - Fotografia exibindo em detalhe, estruturas circulares tipo Anéis de Liesegang, formadas por percolação de hidróxido de ferro. - Afloramento do Km 214.5 da Dutra (sentido Rio - São Paulo).

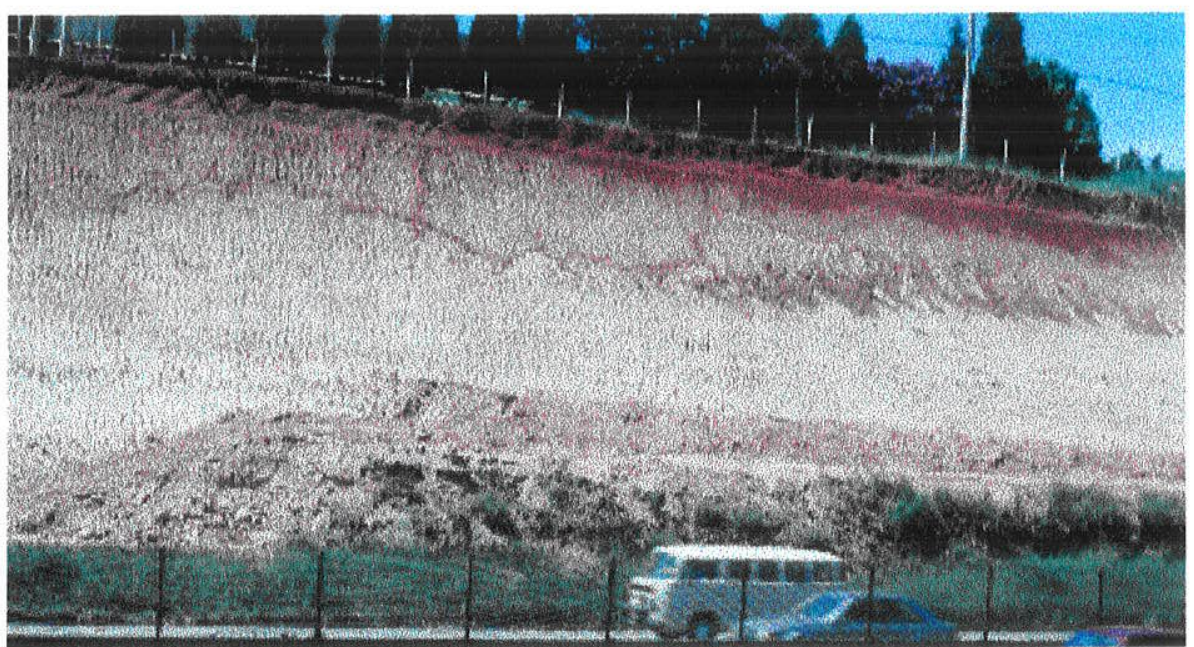

Figura III.5 - Fotografia - Vista geral do afloramento do Km 214,5 da Dutra (sentido São Paulo - Rio).

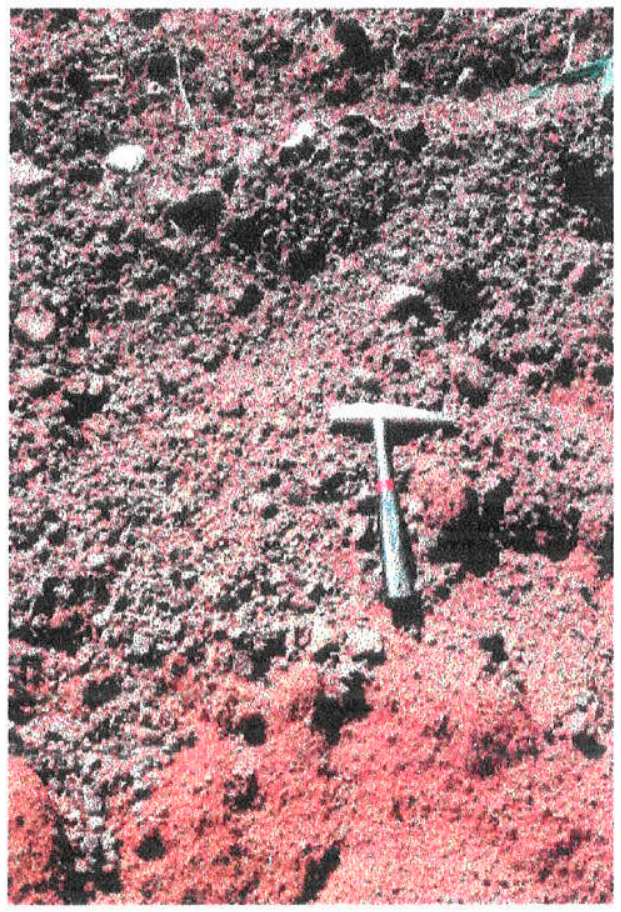

Figura IIII.6 - Fotografia de couraça fragmentada - Porção direita do afloramento do $\mathrm{Km} 214,5$ da Dutra (sentido São Paulo - Rio). 
O afloramento do Km 211,5 é dividido em duas porções. Uma porção basal (próxima ao acostamento da rodovia) com 50m de extensão, e $5 \mathrm{~m}$ de altura, apresenta sequência de espessas crostas ferruginosas (10 a $20 \mathrm{~cm}$ ) horizontalizadas, encaixadas em matriz areno-argilosa.

A outra porção, localizada no topo do corte da estrada, possui aproximadamente 20m de extensão e $5 \mathrm{~m}$ de altura. É constituída por finas crostas ferruginosas dobradas, encaixadas em matriz argilosa (Figura III.7).

$\mathrm{Na}$ porção localizada no topo do afloramento ocorrem estruturas deformadas constituídas por crostas pouco espessas (1 a $5 \mathrm{~cm}$ ), semelhantes a estruturas sedimentares primárias, tipo estratificação cruzada. São observadas também, crostas verticalizadas truncando crostas horizontalizadas (Figura III.8).

A litologia local é caracterizada por sedimento alterado, argilo-arenoso (matriz) de coloração amarelada, às vezes avermelhada, e grãos de quartzo milimétricos $(0,1$ a $0,5 \mathrm{~cm}$ ). As crostas são constituídas por material ferruginoso (óxidos e hidróxidos de ferro) que fornecem a este material cor marrom.

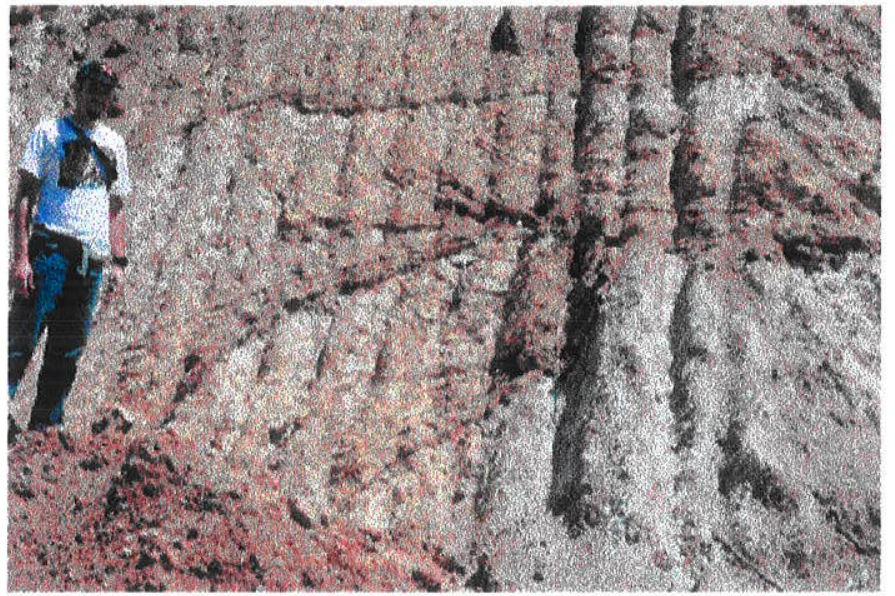

Figura III.7 - Fotografia exibindo crostas ferruginosas deformadas, semelhantes a estruturas sedimentares primárias (Afloramento do Km 211,5 da Dutra - sentido Rio - São Paulo).

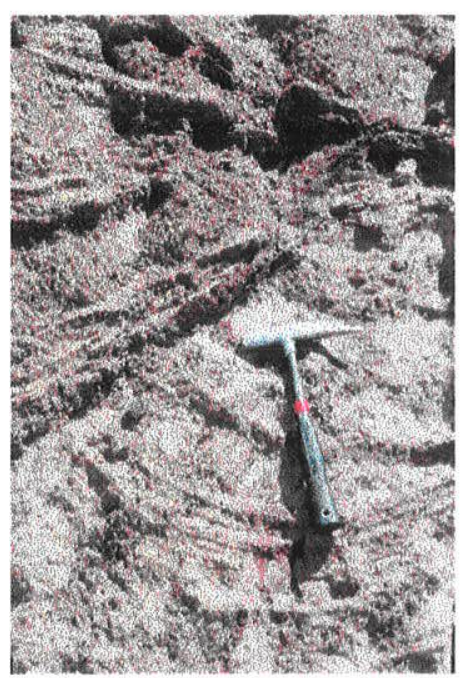

Figura III.8 - Fotografia de detalhe das crostas deformadas. Afloramento do Km 211,5 da Dutra - sentido Rio - São Paulo). 
Afloramento da Rua Girassol - Vila Madalena - São Paulo - SP (Área - 2)

O afloramento estudado possui $40 \mathrm{~m}$ de extensão e $5 \mathrm{~m}$ de altura. Neste local ocorre sequência rítmica de crostas ferruginosas dobradas com $2 \mathrm{~m}$ de espessura, encaixada em matriz areno-argilosa homogênea.

A litologia local é caracterizada por sedimento alterado, areno-argiloso (matriz) de coloração ocre-amarelada com grãos de quartzo de 0,2 a $1,5 \mathrm{~cm}$. Feldspatos alterados esbranquiçados ocorrem como parte da matriz. Ocorrem também intercalações de níveis quartzosos pouco espessos $(0,5 \mathrm{~cm})$.

As crostas são constituídas por material ferruginoso e quartzo, às vezes com granulometria grossa (> $2 \mathrm{~mm}$ ). Aparecem deformadas na porção direita do afloramento, constituídas por crostas mais finas $(0,3$ a $0,5 \mathrm{~cm})$, formando pacotes com aproximadamente $20 \mathrm{~cm}$ de espessura. Na porção esquerda do afloramento, estas crostas são mais espessas (5 a $15 \mathrm{~cm})$ e aparecem de forma mais individualizada (Figuras III.9, III.10, III.11 e III.12).

As crostas são constituídas por óxidos e hidróxidos de ferro que fornece as mesmas cor marrom escura. O pacote possui aproximadamente $2 \mathrm{~m}$ de espessura e é capeado por uma camada de solo homogênea.

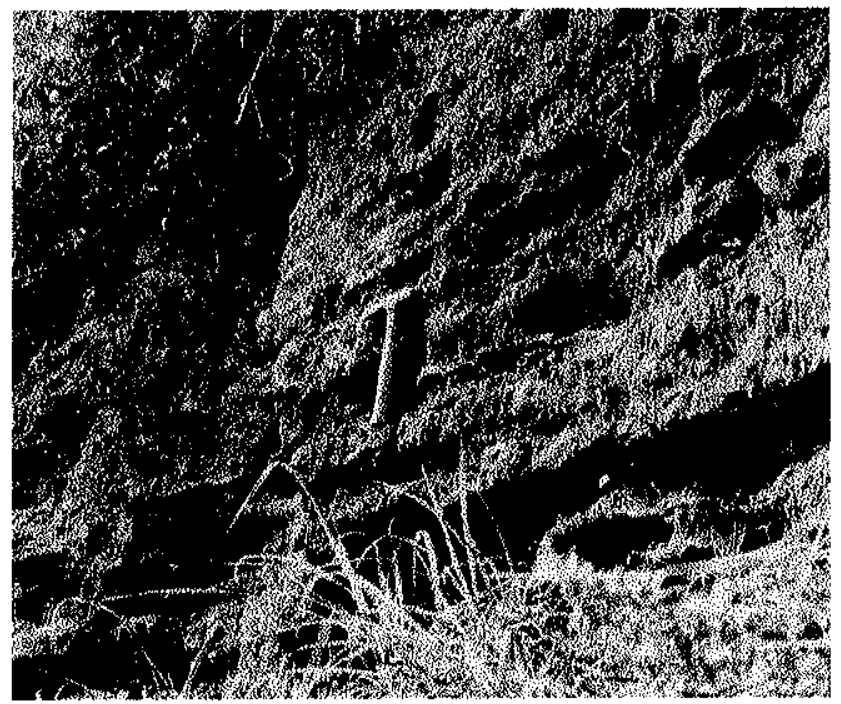

Figura III.9 - Fotografia das Crostas ferruginosas dobradas do afloramento da Rua Girassol, Vila Madalena (Detalhe - Porção esquerda do afloramento). 


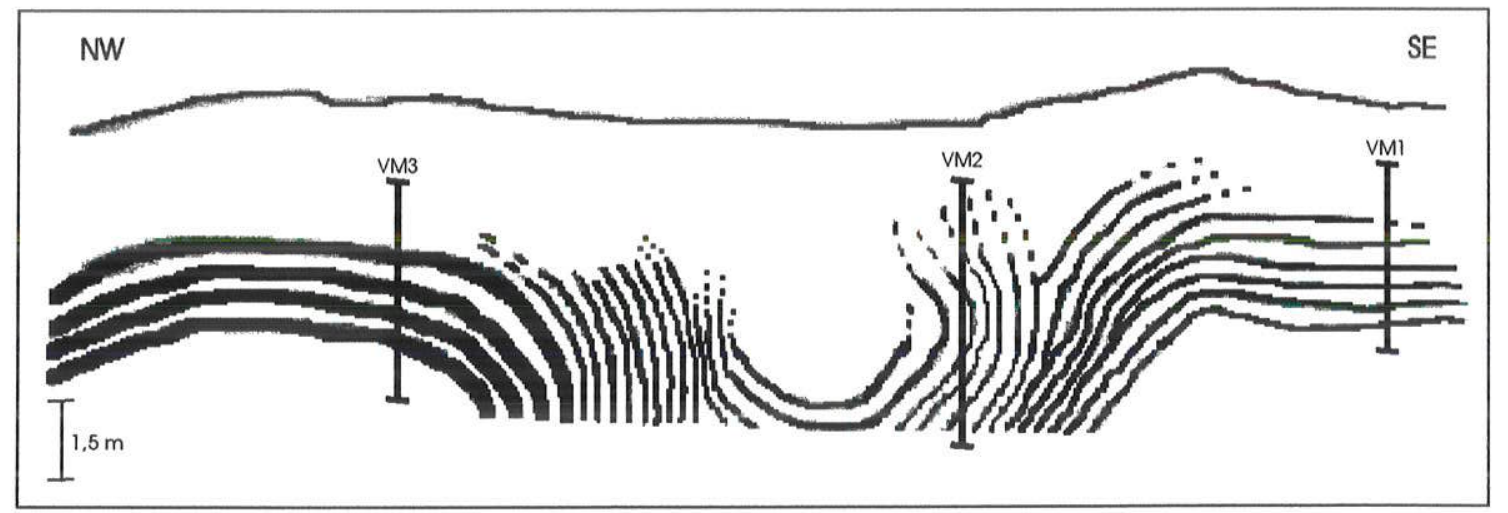

Figura III.10 - Croqui esquemático do afloramento da Vila Madalena (Área 2), exibindo a localização dos perfis de amostragem (VM).

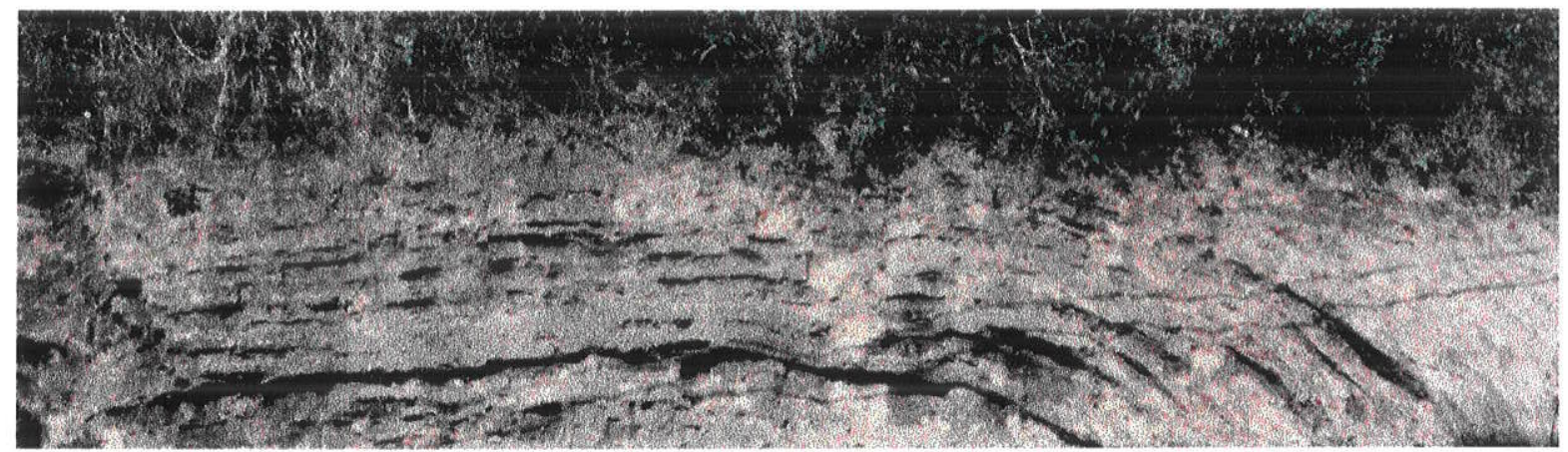

Figura III.11 - Fotografia das crostas ferruginosas dobradas da porção direita do afloramento da Rua Girassol, Vila Madalena.

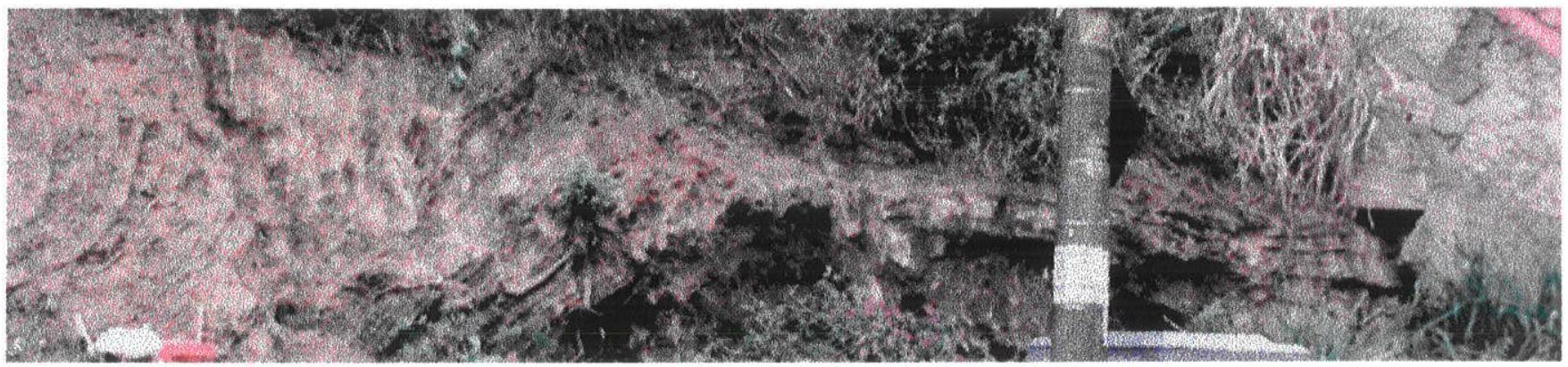

Figura III.12- Fotografia das crostas ferruginosas dobradas da porção esquerda do afloramento da Rua Girassol, Vila Madalena. 
Afloramento da Estrada dos Romeiros Km 53 - Pirapora do Bom Jesus, SP (Área - 3)

O afloramento estudado possui aproximadamente $140 \mathrm{~m}$ de extensão e $20 \mathrm{~m}$ de altura. É dividido em uma porção dobrada com $120 \mathrm{~m}$ de extensão e outra porção sem dobras com 20m (Figuras III.13 e III.14).

A litologia local é caracterizada por sedimento alterado, argiloso (matriz), de coloração avermelhada, com matizes argilosos brancos, fragmentos de quartzo leitoso, angulosos com 3 a $5 \mathrm{~cm}$ e clastos placóides de rocha filítica do Grupo São Roque. Nódulos maciços amarelados de argila e "condutos" preenchidos por material argiloso esbranquiçado, ocorrem como parte da matriz. Esta conjugação de argilas avermelhadas e amarelo-claras fornecem aspecto de argila variegada para a matriz (Figuras III.15 e III.16).

Neste local ocorrem estruturas deformadas, sendo uma das porções do afloramento constituída por uma única couraça ferruginosa indeformada, contínua, com $20 \mathrm{~cm}$ de espessura localizada no topo do perfil.

$\mathrm{Na}$ outra porção, ocorrem estruturas dobradas, organizadas numa sequência de horizontes ferruginosos, constituídos por óxidos e hidróxidos de ferro (domínio de goethita), fornecendo a esses horizontes cor marrom-avermelhada. A estes horizontes, intercala-se sedimento areno-argiloso, de cor amarelo-clara (matriz) (Figura III.17).

A espessura das crostas dobradas varia de 1 a 10 centímetros. Estas crostas são visíveis a partir da base do perfil. As crostas dobradas estendem-se até aproximadamente $15 \mathrm{~m}$ de altura e são capeadas por camada de solo homogênea, com $5 \mathrm{~m}$ de espessura (Figura III. 14).

Observam-se, neste afloramento, quatro grupos distintos de fraturas ou eventuais falhas.

O primeiro grupo (G1) formado por fraturas individualizadas, sem preenchimento e 0 segundo (G2) formado por fraturas preenchidas por hidróxidos de ferro, com até $10 \mathrm{~cm}$ de espessura, onde as dobras encontram-se "encaixadas". Ambos parecem ser mais antigos (F2, F3, F4, F5, F8 e F9 - Figura III.13). 
O terceiro grupo (G3) é formado por conjunto de fraturas pouco espessas (2 a $5 \mathrm{~cm}$ ), preenchidas por hidróxidos de ferro. Estas fraturas ora condicionam o fechamento das "dobras", ora cortam as mesmas (CF - Figura III.13).

O quarto conjunto é constituído por falhas que seccionam e deslocam as crostas deformadas (F7, F10 e F11 - Figura III.13). Estes últimos grupos sugerem eventos mais recentes de reativação tectônica (Figuras III.13, III.14 e III.18). 


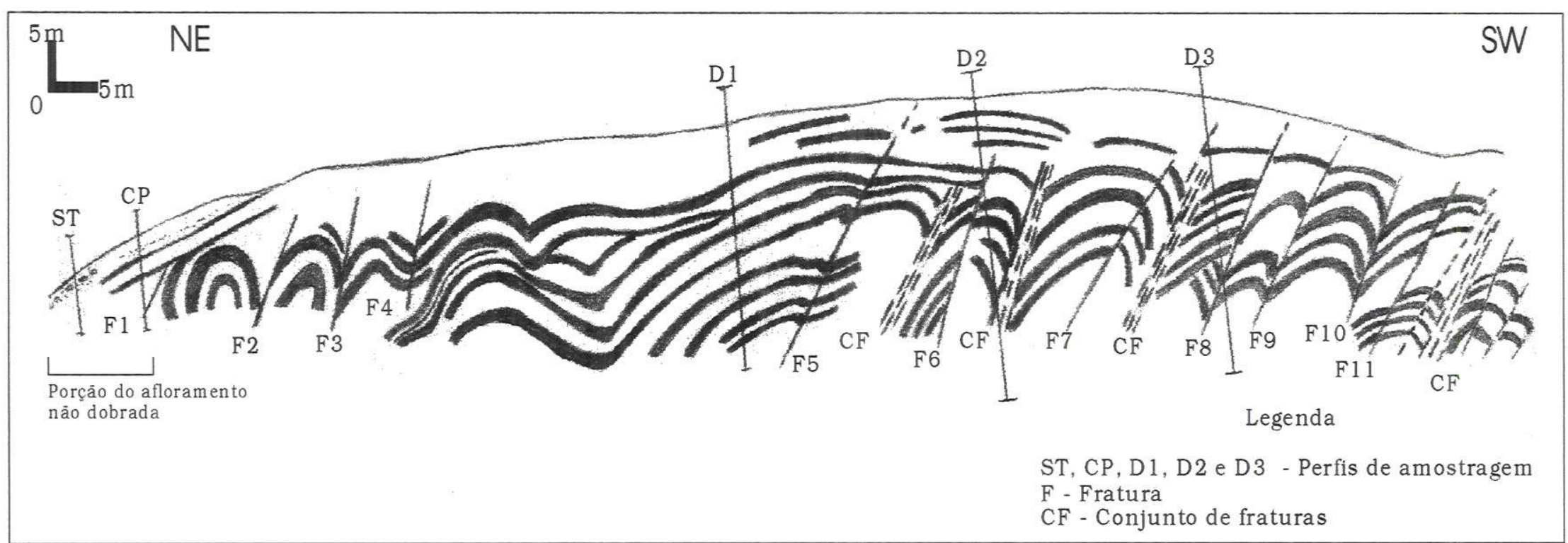

Figura III.13 - Croqui esquemático do afloramento de Pirapora, exibindo a localização dos perfis de amostragem e os grupos de fraturas encontrados

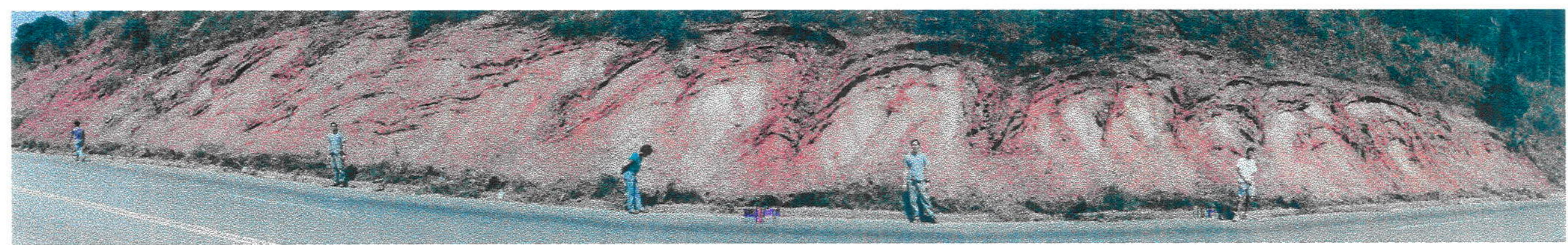

Figura III.14 - Fotografia - Vista geral do afloramento de Pirapora do Bom Jesus - SP. 


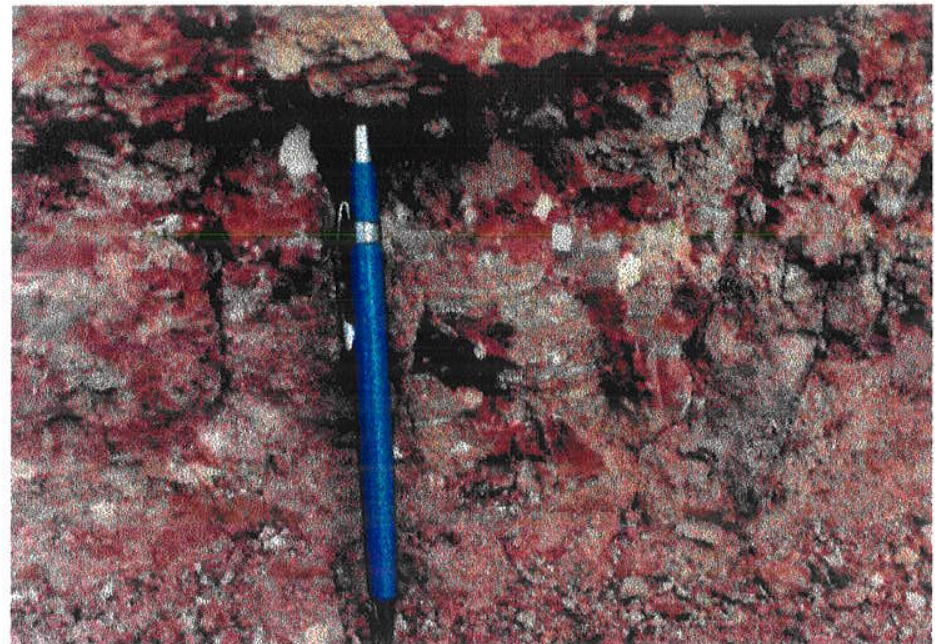

Figura III.15 - Fotografia da porção do afloramento de Pirapora onde ocorrem as "dobras", exibindo sedimento alterado, argiloso (matriz) de cor vermelho-clara, com matizes argilosos brancos, fragmentos de quartzo leitoso centimétricos, angulosos ( 3 a $5 \mathrm{~cm}$ ) e clastos placóides de rocha filitica.

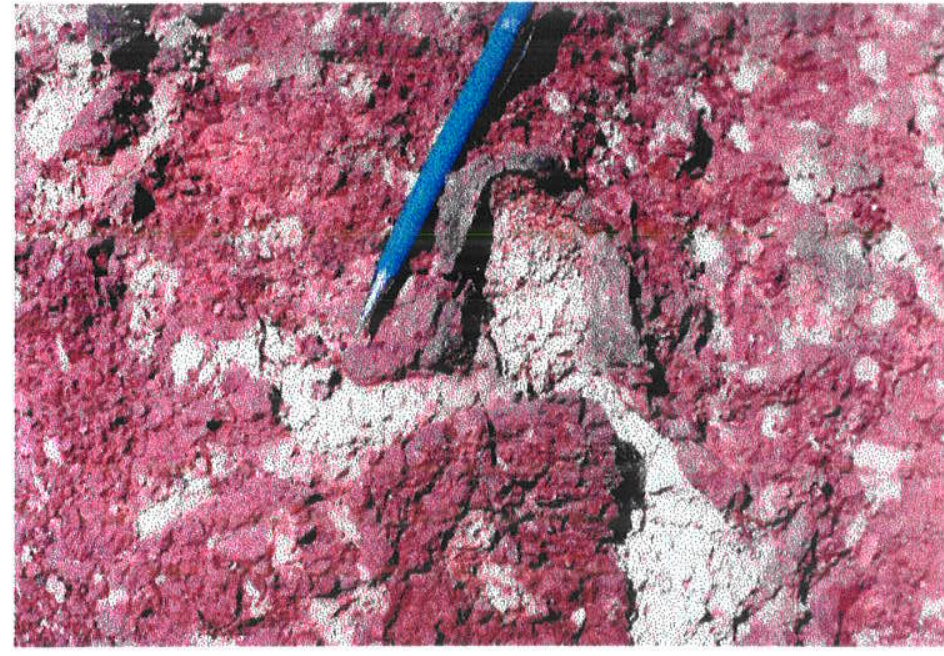

Figura III.16 - Fotografia (detalhe) da argila variegada, exibindo nódulos maciços amarelados de argila $e$ "condutos" preenchidos por material argiloso esbranquiçado (Porção do afloramento sem dobras Pirapora).

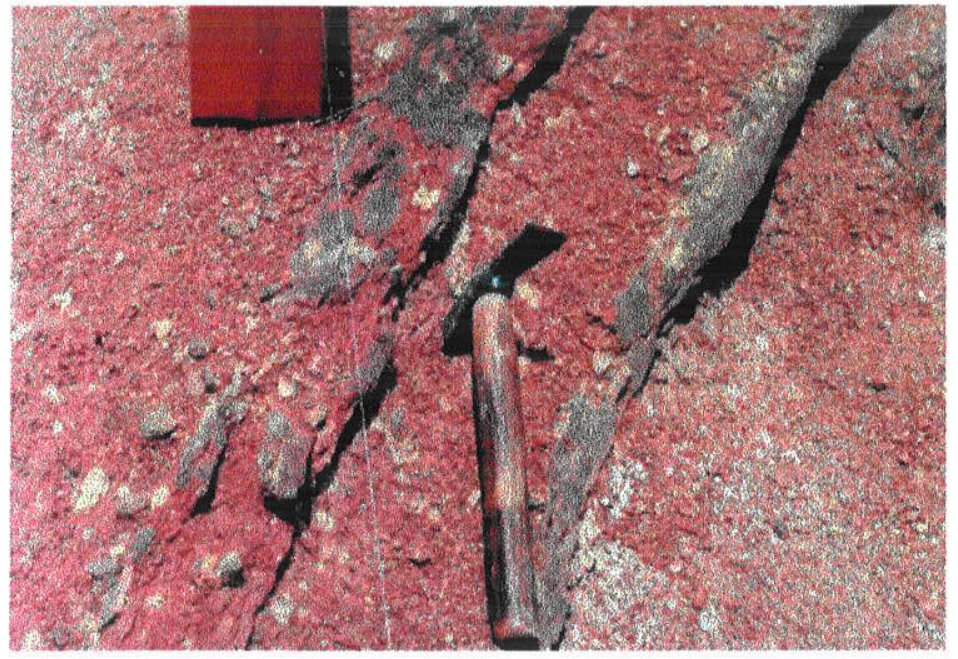

Figura III.17 - Fotografia das crostas deformadas intercaladas por sedimento argilo-arenoso, de cor amarelo-clara (Pirapora).

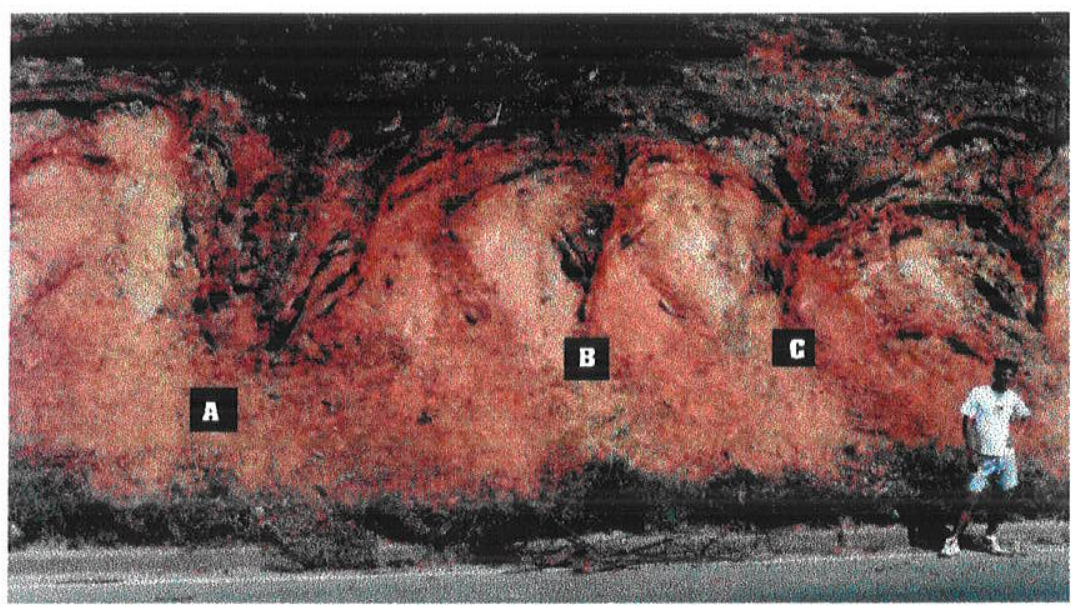

Figura III.18 - Fotografia de parte do afloramento de Pirapora, exibindo três conjuntos de fraturas: (A) - Grupos de fraturas (G3), preenchidas por hidróxidos de ferro. (B) -Fraturas individualizadas, preenchidas por hidróxidos de ferro, que ora truncam os flancos das "dobras"(G4), ora encaixam as mesmas (G2) (C). 


\section{METODOLOGIA EMPREGADA}

Os métodos empregados nesta dissertação na tentativa de diagnosticar a origem dos dobramentos nas crostas ferruginosas foram:

- Pesquisa bibliográfica envolvendo trabalhos realizados nas proximidades das áreas estudadas, enfatizando levantamentos estruturais e petrográficos por um lado, e por outro, trabalhos clássicos que versam sobre a formação de estruturas e deformações de origem atectônica;

- Trabalhos de campo com o objetivo de reconhecer e detalhar as estruturas, tanto morfológica como estruturalmente, através de fotografias, confecção de croquis, levantamento estrutural e coleta de amostras;

- Análise estrutural;

- Análise macroscópica;

- Análise em microscopia óptica (investigação micromorfológica);

- Análises químicas totais;

- Análises químicas pontuais qualitativas e semi-quantitativas em MEV / EDS;

- Determinação mineral por Difração de Raios - X das frações argilosas;

- Análises de minerais pesados dos diferentes fácies.

\section{Amostragem}

Para a obtenção das amostras foram construídos perfis de amostragem pontual similar a coleta de perfis em topossequência. A amostragem das crostas ferruginosas endurecidas compreendeu tanto a porção dura (crostas) como os sedimentos imediatamente sotopostos e superpostos às crostas (matriz). Foram coletadas amostras totais destinadas à análises químicas e amostras indeformadas utilizadas na análise em microscópico óptico (petrografia óptica). 
As amostras cadastradas como DT provêm dos perfis de amostragem dos afloramentos da Rodovia Presidente Dutra (Área 1) e as amostras cadastradas como VM dos perfis de amostragem do afloramento da Vila Madalena (Área 2). As amostras cadastradas como PD compreendem as obtidas nos perfis de amostragem do afloramento de Pirapora do Bom Jesus (Área 3).

Para designar as amostras correspondentes à matriz foi utilizada como código a letra M, e para as amostras correspondentes as crostas a letra C. Para a localização das amostras no perfil foi adotada numeração $1,2,3$, etc., respectivamente da base para 0 topo do perfil.

\section{Análise Estrutural}

Foram medidos e analisados os parâmetros geométricos, morfológicos e as orientações preferenciais das diferentes estruturas encontradas (dobras, fraturas, falhas e lineações). Os dados foram obtidos utilizando-se bússola Brunton.

Para melhor caracterizar as dobras presentes no afloramento, foram estudados seus elementos geométricos extraindo as direções dos flancos, charneiras e linhas de charneira. Superfícies e planos axiais não puderam ser medidos devido a posição do corte da estrada em relação a tais elementos estruturais.

A partir destes dados, foi analisado o grau de simetria dos elementos geométricos, para se entender a origem da deformação e classificar morfologicamente estes dobramentos dentro de um contexto tipicamente estrutural.

As medidas de direções obtidas por pesquisadores em trabalhos executados nas proximidades das áreas estudadas foram retrabalhadas, com a intenção de estabelecer correlações entre as direções preferenciais obtidas nos afloramentos. Através dessas orientações, verificou-se o comportamento da litologia que aloja as dobras, a partir de diagramas estruturais, os prováveis esforços, suas tendências, os quais foram posteriormente comparados com o padrão das dobras em estudo.

Os dados extraídos em campo foram tabelados e tratados estatisticamente. Com a aplicação dos softwares QuickPlot e Stereonet, foram confeccionados diversos 
estereogramas representativos de feições estruturais como: pólos dos planos _de fratura, flancos de dobras, zonas de concentração e orientações preferenciais.

Foram relacionadas as estruturas presentes com sua possível origem deformacional, decorrente de esforços tectônicos. Através das relações estabelecidas nos diagramas de Schimdt-Lambert, foram observadas as similaridades ou diferenças significativas entre os padrões de deformação observados tanto no Grupo São Roque como na Bacia de São Paulo, buscando encontrar similaridade deformacional entre as dobras estudadas e estes.

\section{Análise Macroscópica}

Foram seguidos procedimentos convencionais de descrição de campo. Tais procedimentos permitiram identificar os diferentes materiais encontrados $e$ as características dos constituintes da rocha, como grau de arredondamento, tamanho e desenvolvimento dos grãos minerais constituintes tanto secundários como primários.

\section{Análise em Microscópio Óptico}

Para a confecção de lâminas delgadas, parte das amostras foi impregnada utilizandose a mistura: resina sintética (Resapol T-208), monômero de estireno (solvente) e catalizador (Peroxol G-10).

Uma parcela das amostras foi impregnada utilizando-se a mistura: Araldite CY-248 (Epoxglass), endurecedor Hy-956 e acetona comercial. Este procedimento após secagem do material friável, possibilitou o corte sem prejuízo da estrutura primária da rocha alterada, evitando desta forma a perda de materiais das amostras e a destruição das estruturas originais.

O procedimento empregado na impregnação fundamenta-se nas metodologias propostas por Verbeke (1969), Jongerius e Heintzberger (1975) e Guilloré (1981), com adaptações nas preparações sugeridas em Parisot et al. (1986).

Através da observação em microscópio óptico das lâminas delgadas, efetuou-se a identificação mineralógica e a análise micromorfológica dos constituintes primários e dos produtos de alteração (minerais secundários e estruturas de alteração), como 
diferentes plasmas, recobrimentos de vazios, nodulações, fissuras (intra, inter. e transminerais) com ou sem preenchimento por óxidos e hidróxidos de diferentes origens. Foram analisadas feições de provável modificação nas formas e arranjo dos minerais e as texturas primárias ainda existentes.

Os procedimentos adotados na análise das lâminas foram: descrição das feições, montagens de esquemas, seleção de texturas, esqueletos e fotografias das estruturas. Selecionou-se no microscópio as fases mais significativas, com o objetivo de realizar determinações químicas pontuais qualitativas e semi-quantitativas, através de microscopia eletrônica de varredura (MEV) e espectrometria por dispersão de energia (EDS).

A observação e descrição das lâminas delgadas foi realizada em Microscópio Zeiss e a obtenção das fotografias em Fotomicroscópio Zeiss Axioplan.

\section{Análises Químicas Totais}

Foram executadas análises químicas totais dos materiais coletados nos afloramentos, com a finalidade de determinar a predominância de determinados elementos químicos $\Theta$ a quantidade em porcentagem dos mesmos.

Comparando-se os resultados obtidos nas amostras analisadas, buscou-se identificar a natureza do processo causador da estrutura, caso este provenha de processos geoquímicos, como mobilidade e retenção de compostos químicos.

Para caracterização química dos materiais amostrados foram analisados os óxidos mais comuns ( $\mathrm{Fe}_{2} \mathrm{O}_{3}, \mathrm{Al}_{2} \mathrm{O}_{3}, \mathrm{SiO}_{2}, \mathrm{TiO}_{2}, \mathrm{Na}_{2} \mathrm{O}, \mathrm{K}_{2} \mathrm{O}, \mathrm{MgO}, \mathrm{CaO}$ e $\mathrm{P}_{2} \mathrm{O}_{5}$ ).

Estas análises foram realizadas no Laboratório de Química e Plasma ICP-AES do GMG do IG-USP. A metodologia empregada foi a espectrometria de emissão atômica com fonte de plasma induzido (ICP.AES), com o equipamento modelo ARL-3410 dotado de espectrômetro sequêncial e nebulizador convencional Meinhard. As condições operacionais $e$ instrumentais empregadas seguem os procedimentos segundo Janasi et al. 1996 - Bol. Cient. IG-USP Série Cient. Vol 26, pp 45-58, 1995). 
Após a obtenção dos resultados das análises químicas, as amostras foram distinguidas e agrupadas, como representativas das "crostas dobradas" ( $C$ ), da matriz ( $M$ ), da rocha parental ( $R$ ) e da couraça de cobertura (CP) (no caso do afloramento de Pirapora). Estes resultados foram tratados em diagramas geoquímicos discriminativos, visando detectar evolução similar entre os materiais analisados.

\section{Análises Químicas Pontuais Qualitativas e Semi-quantitativas em MEV (Microscópio Eletrônico de Varredura) e EDS (Espectrômetro por Dispersão de Energia)}

Estas microanálises foram realizadas em lâminas delgadas previamente selecionadas e metalizadas com carbono. A espectrometria por dispersão de energia permite a detecção dos constituintes químicos, sendo realizada de modo pontual com detecção do conteúdo de elementos por análises químicas qualitativas e semi - quantitativas.

O equipamento utilizado foi Um MEV LEO 440 I, equipado com EDS da marca Oxford, pertencente ao Laboratório de Microscopia Eletrônica de Varredura do Departamento de Geologia Sedimentar e Ambiental do IG-USP - SP.

\section{Análises de Minerais Pesados nos Diferentes Fácies}

A análise de minerais pesados foi realizada nos materiais correspondentes a matriz e crostas ferruginosas, com o objetivo de identificar a existência ou não de similaridade composicional de minerais pesados entre estes materiais (crostas, couraça, matriz e rocha mãe).

Primeiramente, as amostras totais foram separadas por composição (matriz e crosta) e por posição no perfil (topo, meio e base). Em seguida, as amostras foram trituradas e moídas, utilizando-se almofariz de ágata, posteriormente pesadas para obtenção de quantidades equivalentes.

As amostras, então, foram colocadas em liquidificador com água destilada e agitadas durante 5 minutos com posterior peneiramento a 400 mesh. $O$ material que passou pela peneira foi separado para análise mineralógica por DRX. Enquanto que o material retido na peneira foi seco em estufa e peneirado nas frações de 16, 35, 100 e 200 
mesh respectivamente. Cada uma destas frações foi separada para a análise de minerais pesados.

A separação e identificação dos minerais pesados foi realizada em lupa binocular comum.

\section{Análise Mineralógica por Difração de Raios - X (DRX) das frações argilosas}

A identificação mineralógica por este método foi empregada somente para fração argila. As amostras a serem irradiadas foram preparadas através do espalhamento do material úmido com espátula, sobre uma lâmina de vidro, permitindo que o material adquiri-se uma orientação preferencial das partículas argilosas.

O aparelho utilizado foi um difratômetro de Raios - X Siemens D5000 e as condições instrumentais foram as seguintes:

Início: $3.000^{\circ}$ - Final: $65.000^{\circ}$ - Passo: $0.050^{\circ}$ - Tempo do passo: 0.5 Seg. 


\section{5 - RESULTADOS OBTIDOS}

Neste capítulo são apresentados os resultados das investigações em Microscopia óptica convencional, a composição mineral por DRX e por Análise de Minerais Pesados, e os resultados obtidos por Análises Químicas Totais e Pontuais Qualitativas e Quantitativas em MEV/EDS. As características macroscópicas dos materiais estudados encontram-se no capítulo III no item Descrição das Áreas Estudadas.

RODOVIA PRESIDENTE DUTRA (ÁREA - 1)

\section{Caracterização Mineralógica dos Materiais}

\section{Caracterização Microscópica}

A observação microscópica dos materiais coletados nos afloramentos da Dutra, através das lâminas petrográficas, permitiu a identificação de minerais primários, representados predominantemente por quartzo e secundariamente por micas.

Os grãos de quartzo apresentam-se de forma e tamanho variado, angulosos a semiangulosos, com feições de corrosão.

Nestes materiais foram identificados dois plasmas distintos. Um constituído predominantemente, por óxidos e hidróxidos de ferro (goethita) que corresponde ao material das crostas ferruginosas. Este plasma possui coloração marrom sob luz natural, e marrom escura a preta sob luz polarizada. O outro plasma corresponde ao material da matriz; é mais argiloso e apresenta coloração amarelada sob luz natural, e marrom clara sob luz polarizada (Figura V.1).

Embora não se tenha realizado análise de porosidade neste materiais, observou-se que a porosidade é mais alta na matriz do que nas crostas, devido a estrutura mais compacta apresentada pelos materiais das crostas, dada pelo preenchimento de fissuras e poros por material argilo-ferruginoso. Essas considerações foram extraídas das análises em microscópio óptico e em MEV.

Em ambos os plasmas, observou-se estruturas de preenchimento concêntrico, formadas em junções de fissuras total ou parcialmente preenchidas por material 


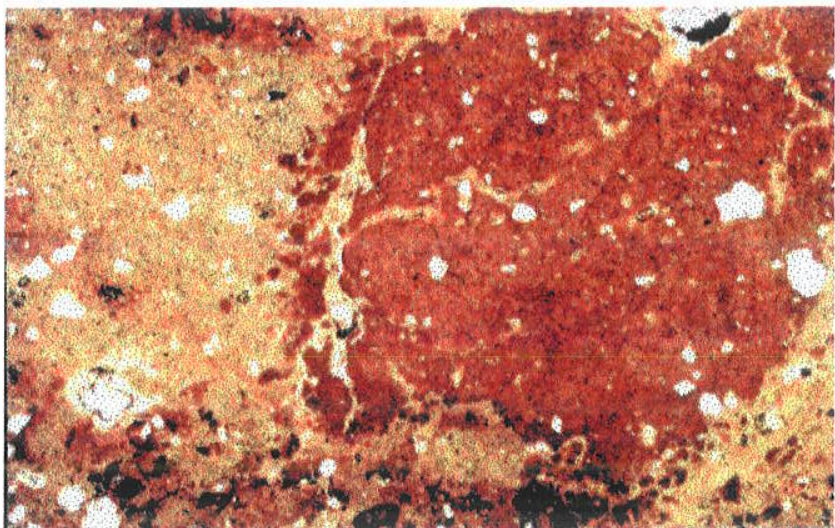

Figura V.1- Fotomicrografia (Luz natural) da região de contato entre o plasma marrom avermelhado da crosta (lado esquerdo) e o plasma amarelado da matriz (lado direito) (aresta horizontal $=5,3 \mathrm{~mm}$ ).

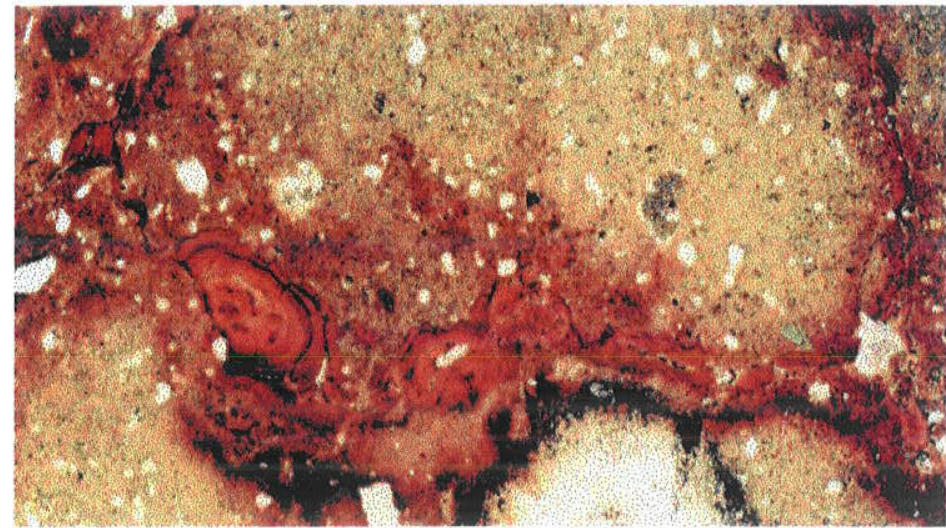

Figura V.2 - Fotomicrografia (Luz natural) exibindo estrutura de preenchimento concêntrico formada por material argilo-ferruginoso, indicativo de dissolução e reprecipitação de ferro em cavidades e fissuras (aresta horizontal $=5.3 \mathrm{~mm}$ ).

argiloso contendo óxidos de ferro (ferriargilan zonado). Estas feições indicam remobilização do ferro ao longo dessas fissuras. (Figura V.2).

\section{Comportamento Químico dos Elementos}

\section{Análises Químicas Totais:}

O comportamento químico de elementos maiores ( $\mathrm{Si}$, Fe e $\mathrm{Al}$ ) ao longo dos perfis analisados, demonstra uma tendência geral à concentração da sílica e alumínio na matriz e do ferro nas crostas (Figura V.3).

Os diagramas geoquímicos discriminativos exibem dois campos de agrupamento, um das amostras das crostas (mais ricas em ferro) e outro das amostras da matriz (mais ricas em sílica e alumínio), como exibido nas figuras V.4 (diagrama $\mathrm{Fe}_{2} \mathrm{O}_{3} \times \mathrm{Al}_{2} \mathrm{O}_{3} \times \mathrm{SiO}_{2}$ ) e V.5 (diagrama $\mathrm{Fe}_{2} \mathrm{O}_{3} \times \mathrm{SiO}_{2}$ ). Observa-se nestes diagramas a formação de trends de evolução geoquímica, os quais sugerem um enriquecimento progressivo, do topo para a base do perfil, em ferro nas crostas e em sílica na matriz (Figura V.6, diagrama $\mathrm{Fe}_{2} \mathrm{O}_{3}+$ $\mathrm{Al}_{2} \mathrm{O}_{3} \times \mathrm{SiO}_{2}$ ). 


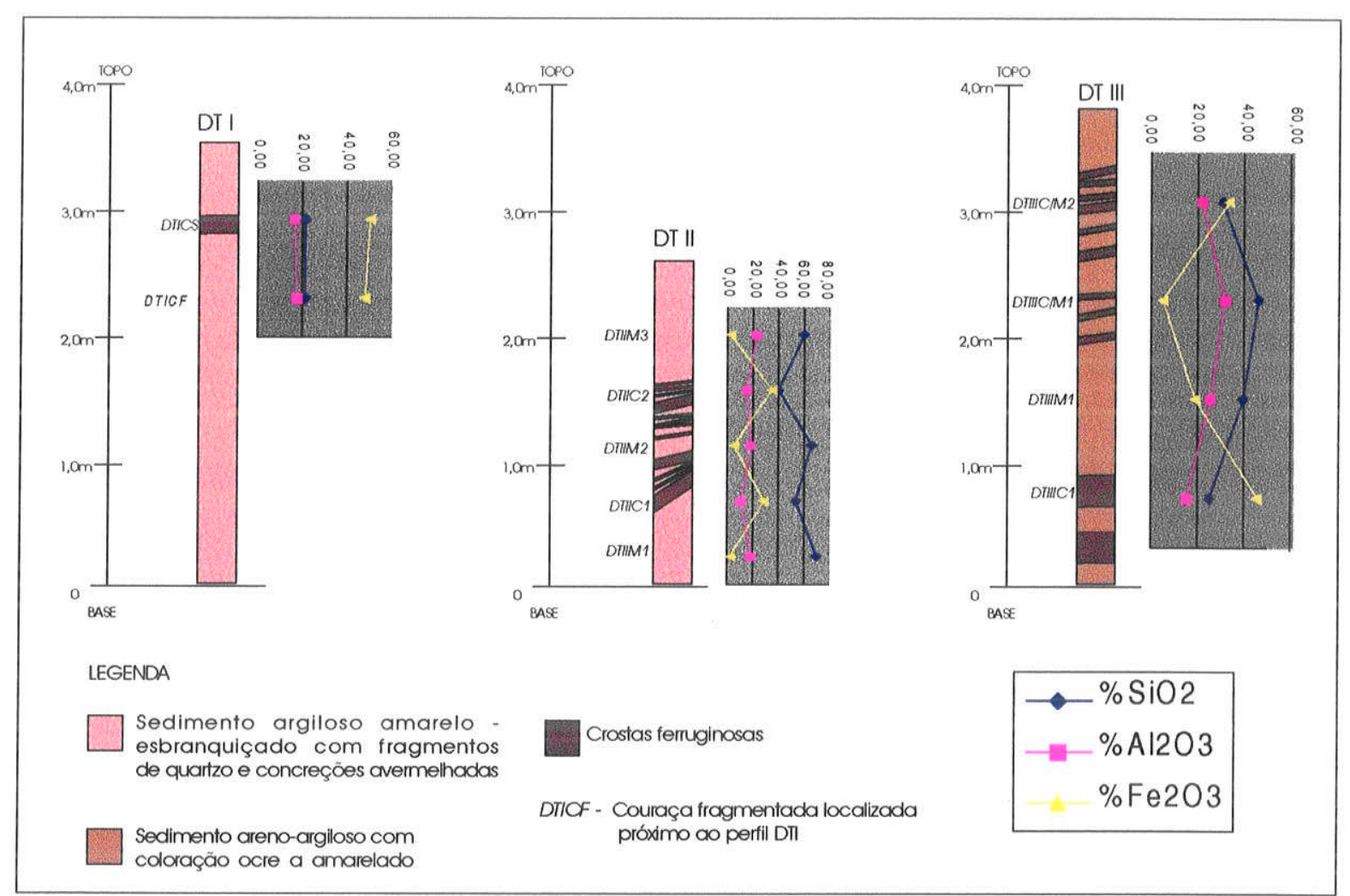

Figura V.3 - Comportamento geoquímico do $\mathrm{Si}$, Al e do $\mathrm{Fe}$ ao longo dos perfis estudados (Afloramentos da Dutra - Área 1).

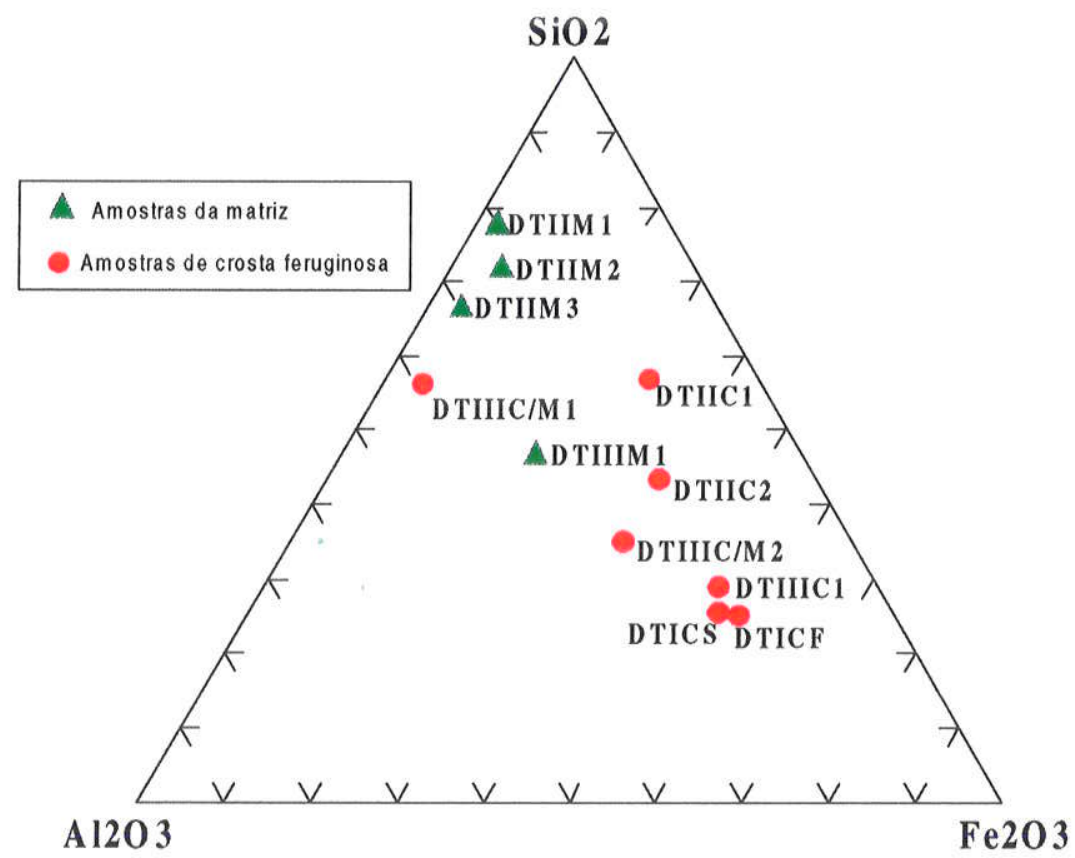

Figura V.4 - Diagrama geoquímico discriminativo $\mathrm{Fe}_{2} \mathrm{O}_{3} \times \mathrm{Al}_{2} \mathrm{O}_{3} \times \mathrm{SiO}_{2}$ (\%) - Distribuição dos campos de agrupamento das amostras (crostas e matriz), em função do comportamento geoquímico do $\mathrm{Si}, \mathrm{Al}$ e do Fe (Dutra - Área 1) . 


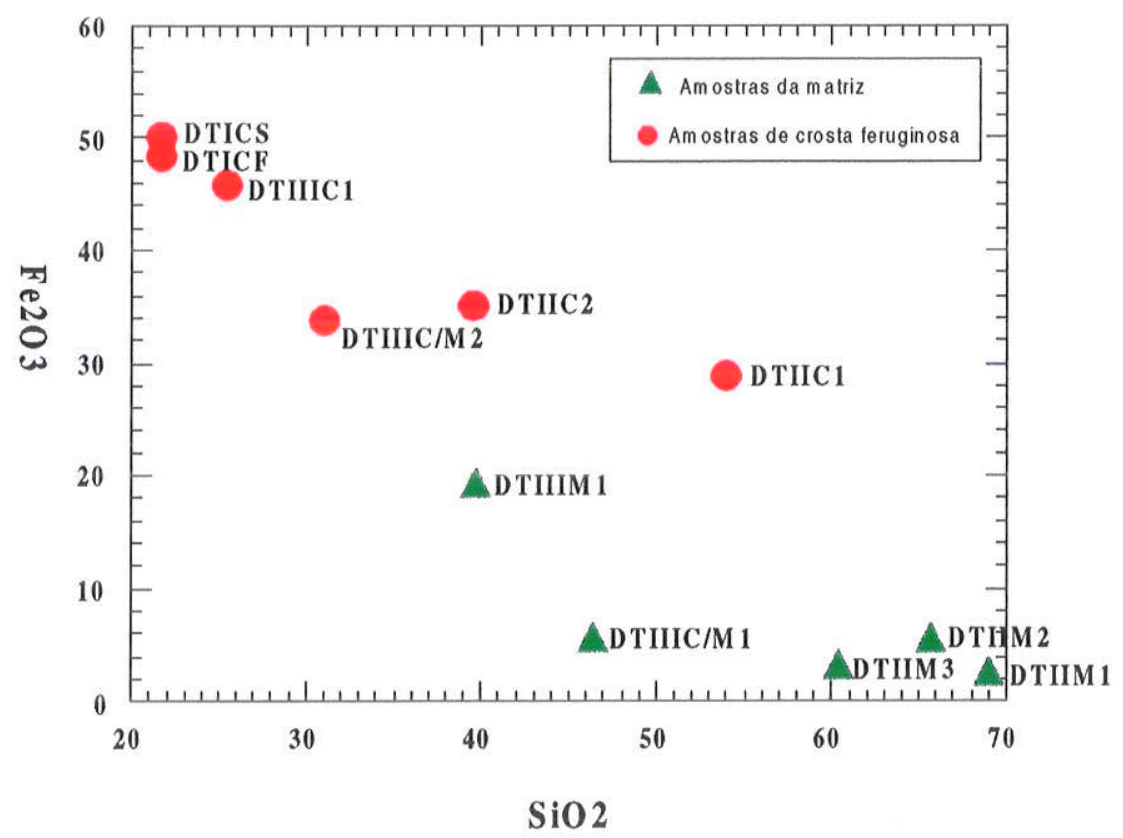

Figura V.5 - Diagrama geoquímico discriminativo $\mathrm{Fe}_{2} \mathrm{O}_{3} \times \mathrm{SiO}_{2}(\%)$ exibindo trends de evolução geoquímica, sugerindo enriquecimento progressivo, do topo para a base do perfil, em ferro nas crostas e em sílica na matriz (Dutra - Área 1).

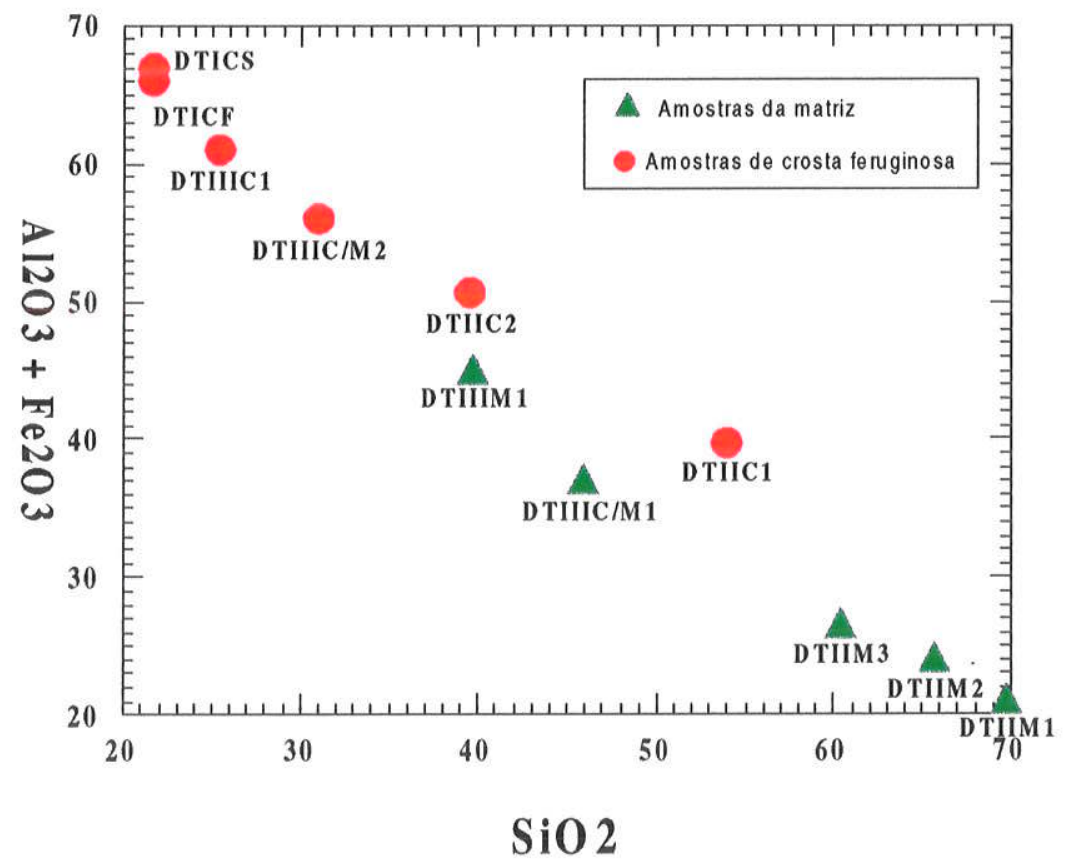

Figura V.6 - Diagrama geoquímico discriminativo $\mathrm{Fe}_{2} \mathrm{O}_{3}+\mathrm{Al}_{2} \mathrm{O}_{3} \times \mathrm{SiO}_{2}(\%)$ exibindo trends de evolução geoquímica, sugerindo enriquecimento progressivo, do topo para a base do perfil, em ferro nas crostas e em sílica na matriz (Dutra - Área 1). 
Observou-se também a eliminação dos elementos alcalinos ( $\mathrm{Mg}, \mathrm{Ca}, \mathrm{Na}$ e K) em todos os horizontes dos perfis analisados e a permanência do titânio em concentrações equivalentes, ao longo dos perfis. O manganês aparece em concentrações baixas e equivalentes nas amostras, assim como acontece com os elementos traços ( $\mathrm{Ba}, \mathrm{Cr}, \mathrm{Ni}$, $\mathrm{Sr}, \mathrm{V} \in \mathrm{Zr}$ ).

Os resultados obtidos nas análises químicas totais para as amostras dos afloramentos da Dutra, encontram-se na tabela V.1.

\begin{tabular}{|c|c|c|c|c|c|c|c|c|c|c|c|}
\hline AMOSTRA & DTCF & OTICS & DTIMAt & DTIIC1 & DTIM2 & DTIC2 & DTIM3 & Drilic1 & Drillat & DTIIIC/M1 & DTIIIC/A2 \\
\hline$\% \mathrm{SiO}_{2}$ & 21,63 & 24,62 & 69,71 & 53,90 & 65,67 & 39,54 & 60,43 & 25,44 & 39,63 & 46.22 & 30,89 \\
\hline$\% \mathrm{Al}_{2} \mathrm{O}_{3}$ & 17,61 & 16,76 & 18.49 & 10,93 & 78,61 & 15,50 & 23.55 & 15,28 & 25,79 & 31,89 & 22,25 \\
\hline$\% \mathrm{Fe}_{2} \mathrm{O}_{3}$ & 48,39 & 50.17 & 2,56 & 28,82 & 5,60 & 35,08 & 3,19 & 45,81 & 19,32 & 5,15 & 33,73 \\
\hline$\% \mathrm{MgO}$ & 0,09 & 0,09 & 0,07 & 0,03 & 0,07 & 0,08 & 0,11 & 0,08 & 0,14 & 0,17 & 0.12 \\
\hline$\% \mathrm{CaO}$ & 0,06 & 0,03 & 0,01 & 0,02 & 0,01 & 0,02 & 0,02 & 0,04 & 0,02 & 0,02 & 0,03 \\
\hline$\% \mathrm{Na}_{2} \mathrm{O}$ & 0,05 & 0,04 & 0,03 & 0,03 & 0,04 & 0,03 & 0,05 & 0,07 & 0,05 & 0,06 & 0,06 \\
\hline$\% \mathrm{~K}_{2} \mathrm{O}$ & 0,40 & 0,41 & 0,37 & 0,22 & 0,37 & 0,42 & 0,56 & 0,44 & 0,70 & 0,80 & 0,62 \\
\hline$\% \mathrm{P}_{2} \mathrm{O}_{5}$ & 0,08 & 0,05 & 0,03 & 0,03 & 0,03 & 0.05 & 0,06 & 0,07 & 0,12 & 0,08 & 0,07 \\
\hline$\% \mathrm{MnO}$ & 0,01 & 0,02 & 0,02 & 0,01 & 0,02 & 0,01 & 0,01 & 0.01 & 0,01 & 0.01 & 0,01 \\
\hline$\% \mathrm{TIO}_{2}$ & 0,85 & 1,00 & 0,95 & 0,62 & 1,00 & 0,89 & 1,15 & 0,78 & 1,36 & 1,81 & 1,19 \\
\hline \%P.F. & $1 t, 83$ & 10.95 & 7,64 & 6,80 & 7,74 & 9,31 & 9,49 & 11,91 & 12.26 & 12,57 & 12,23 \\
\hline \% Total & 100,98 & 101,12 & 99,89 & 101,42 & 99,17 & 100,93 & 98,62 & 99,93 & 99,40 & 88,88 & 101,29 \\
\hline $9 \mathrm{H}_{2} \mathrm{O}^{\circ}$ & 2,02 & 2,85 & 1,83 & 0,99 & 1,28 & 2,59 & 1,99 & 2,46 & 2,23 & 2,06 & 1,98 \\
\hline & & & & & & & & & & & \\
\hline $\mathrm{Ba}(\mathrm{ppm})$ & 102 & 130 & 103 & 54 & 100 & 110 & 162 & 107. & 176 & 235 & 155 \\
\hline Cr $(p p m)$ & 180 & 34 & 17 & 85 & 15 & 74 & 37 & 90 & 124 & 61 & 74 \\
\hline Ni $\{\mathrm{ppm}\}$ & 18 & 36 & $<15$ & $<15$ & $\leq 15$ & $<15$ & $\leq 15$ & 31 & 21 & $<15$ & $\leq 15$ \\
\hline $\mathrm{Sr}(\mathrm{ppm})$ & 38 & 65 & 36 & 10 & 36. & 38 & 67 & 37 & 66 & 89 & 54 \\
\hline $\mathrm{V}$ (pprm) & 286 & 123 & 64 & 140 & 75 & 631 & 102 & 197 & 366 & 126 & 224 \\
\hline $\mathrm{Zr}(\mathrm{pgm})$ & 298 & 284 & 797 & 660 & 750 & 779 & 846 & 244 & 383 & 496 & 320 \\
\hline
\end{tabular}

Tabela V.1 - Resultados das análises químicas totais por ICP-AES para as amostras coletadas nos perfis da Dutra (Área 1).

\section{Análises Químicas Pontuais:}

As análises qualitativas em MEV/EDS das lâminas pertencentes ao afloramento da Dutra, confirmaram que as crostas são compostas principalmente por $\mathrm{Si}$, Fe e AL. As elevadas concentrações de ferro na região das crostas estão relacionadas à presença de fissuras, preenchidas por óxidos e hidróxidos de ferro, e nódulos ferruginosos (Figura V.7). A matriz é composta essencialmente por sílica e possui baixa concentração de ferro e alumínio (Figura V.8). 


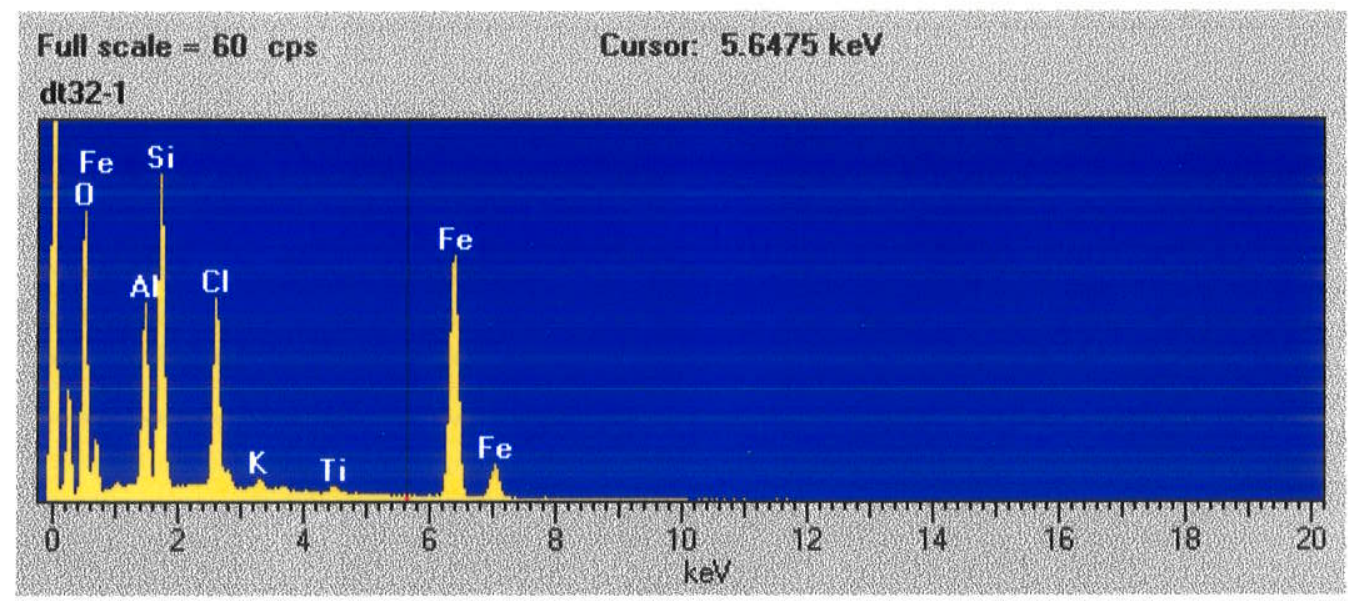

Figura V.7 - Espectro de EDS com análise qualitativa da região da crosta (Dutra - Área - 1). Destacamse os picos do silício $(\mathrm{Si})$, ferro $(\mathrm{Fe})$, alumínio $(\mathrm{Al})$, componentes principais das crostas ferruginosas e os picos do titânio $(\mathrm{Ti})$, potássio $(\mathrm{K})$ e oxigênio $(\mathrm{O})$. O pico de cloro $(\mathrm{Cl})$ provêm da resina utilizada na impregnação dos materiais para a confecção das lâminas delgadas.

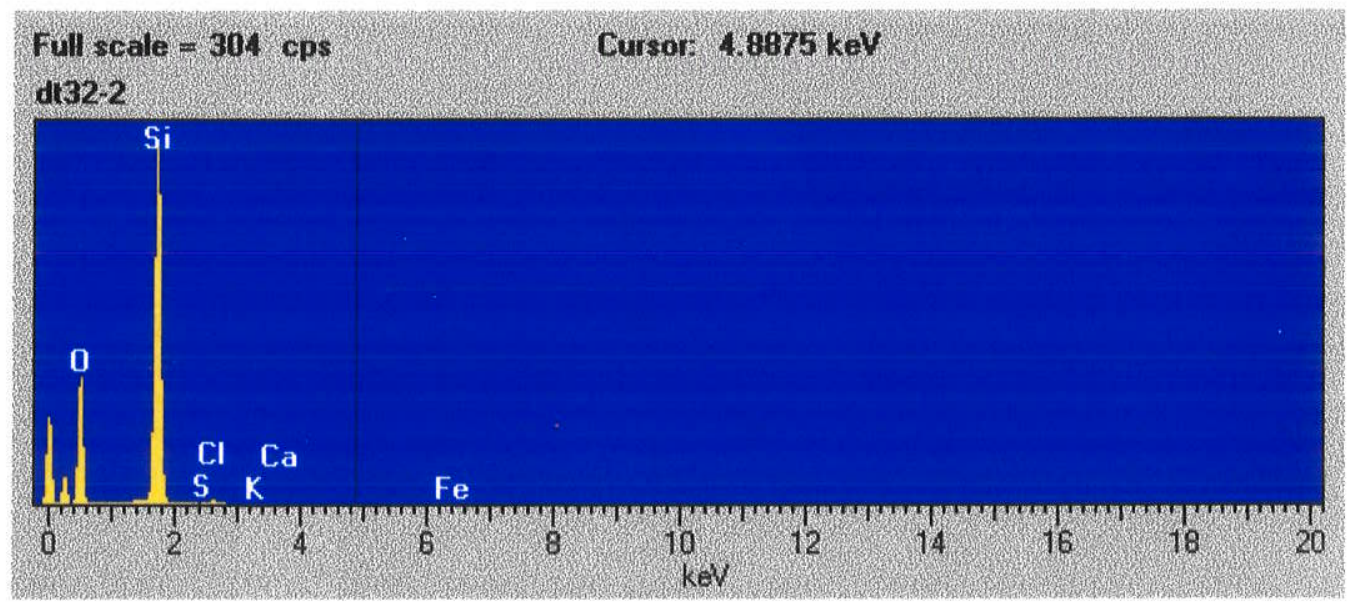

Figura V.8 - Espectro de EDS com análise qualitativa da região da matriz (Dutra - Área - 1). Destaca-se a predominância do silício (Si) e a baixa concentração de ferro $(\mathrm{Fe})$. 


\section{RUA GIRASSOL - VILA MADALENA - SP (ÁREA-2)}

\section{Caracterização Mineralógica dos Materiais}

\section{Caracterização Microscópica}

Através da observação microscópica das lâminas petrográficas das amostras pertencentes a este afloramento, foi possivel identificar a presença de minerais primários representados predominantemente por quartzo e secundariamente, turmalina e mica (biotita) (Figura V. 9).

Os grãos de quartzo apresentam-se angulosos a sub-angulosos, com tamanho variado. Alguns grãos apresentam-se com feições de corrosão ou microfissurados, sendo que estas fissuras intraminerais muitas vezes encontram-se preenchidas por material ferruginoso (hidróxido de ferro), como pode ser observado na figura V.10.

Na região correspondente às crostas, os grãos minerais encontram-se envoltos por plasma ferruginoso, fino e compacto, de coloração marrom avermelhada sob luz polarizada, e marrom escura sob luz natural. Na região correspondente a matriz, o plasma possui coloração marrom escura, sob luz polarizada e amarela, sob luz natural (Figura V.11).

Foram observadas algumas fissuras e vazios totalmente preenchidos por material constituido de argila e hidróxidos de ferro, com granulometria mais fina do que o plasma do entorno. Fissuras preenchidas por material caolinítico amarelo, fino, às vezes granulado, ocorrem com frequência. Em algumas dessas fissuras, ocorrem estruturas de preenchimento que exibem bandamento concêntrico, formado pela segregação de ferro e argila no interior de cavidades. Estas estruturas são denominadas ferriargilans zonados. (Figuras V.11, a V.16).

Foi possível identificar que a região compreendida pela matriz possui porosidade mais elevada do que a região das crostas, que apresenta um arranjo mais compacto entre os grãos minerais e o plasma ferruginoso. 


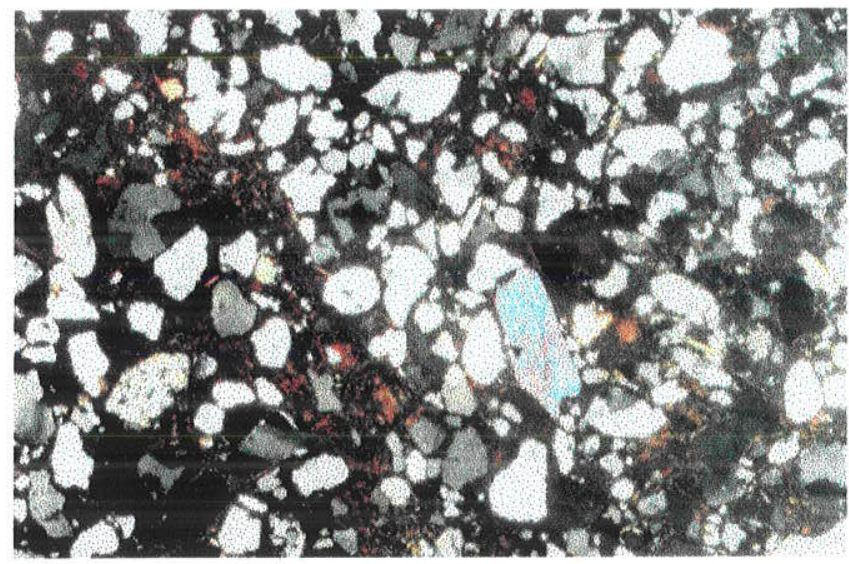

Figura V.9 - Fotomicrografia (Luz polarizada) Aspecto geral do plasma da região da matriz, exibindo grande quantidade de grãos de quartzo e fragmento de mica à direita (aresta horizontal $=5,3$ $\mathrm{mm})$.

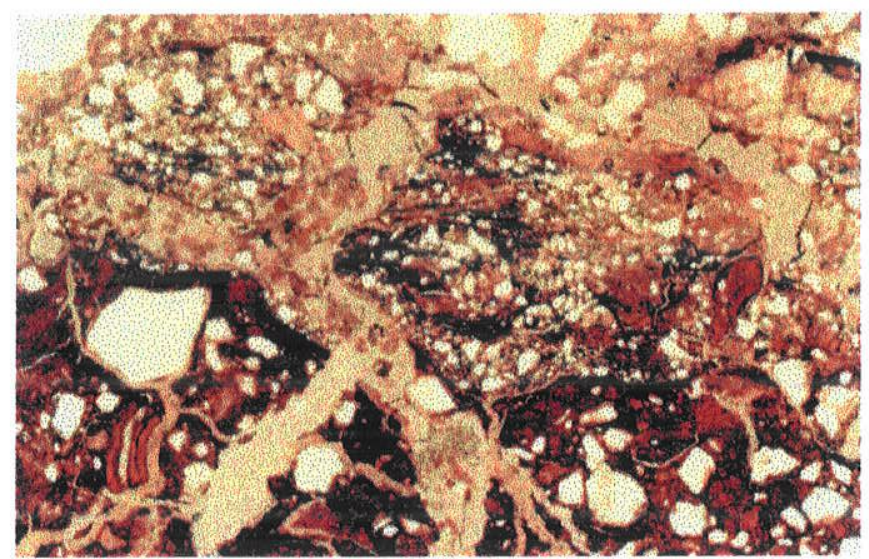

Figura V.11 - Fotomicrografia (Luz natural) - Contato entre plasma da crosta, vermelho escuro (parte inferior da foto) e plasma da matriz, amarela (parte superior da foto) - Fissuras preenchidas por material granulado, indicativo de remobilização (aresta horizontal $=5,3$ $\mathrm{mm})$.

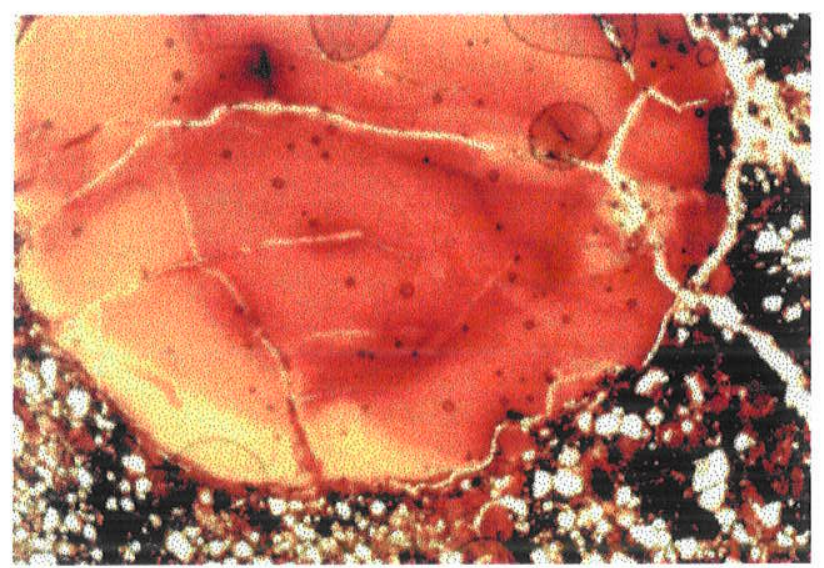

Figura V.13 - Fotomicrografia (Luz natural) Estrutura de preenchimento esferoidal - Material argilo-ferruginoso (ferriargilan) (região da crosta) (aresta horizontal $=5,3 \mathrm{~mm}$ ).

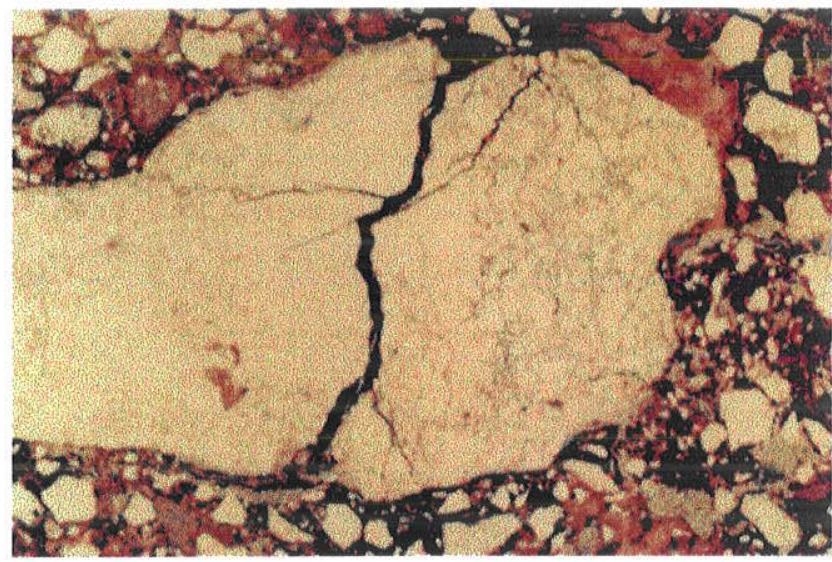

Figura V.10 - Fotomicrografia (Luz natural) - Grão de quartzo cortado por fissura preechida por hidróxidos de ferro (aresta horizontal = 5,3 $\mathrm{mm}$ ).

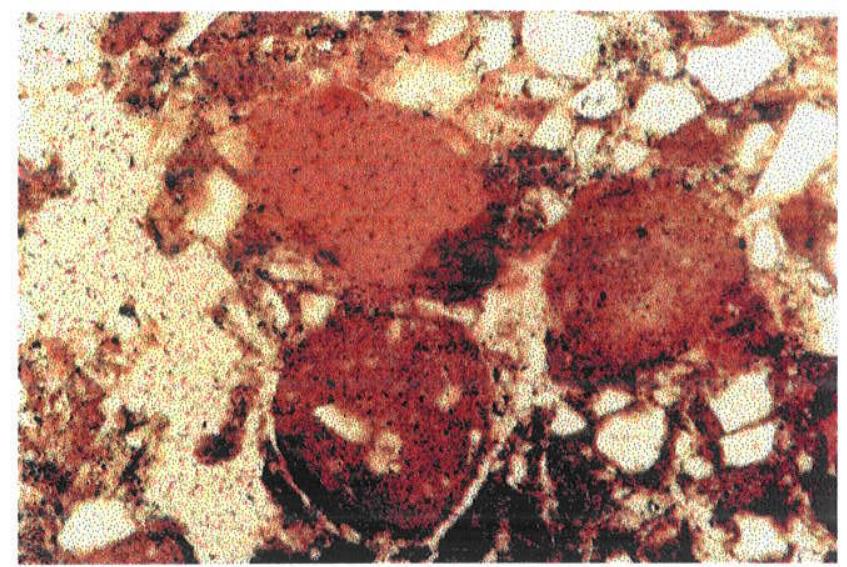

Figura V.12 - Fotomicrografia (Luz natural) Estruturas de preenchimento esferoidais (aresta horizontal $=1,39 \mathrm{~mm}$ ).

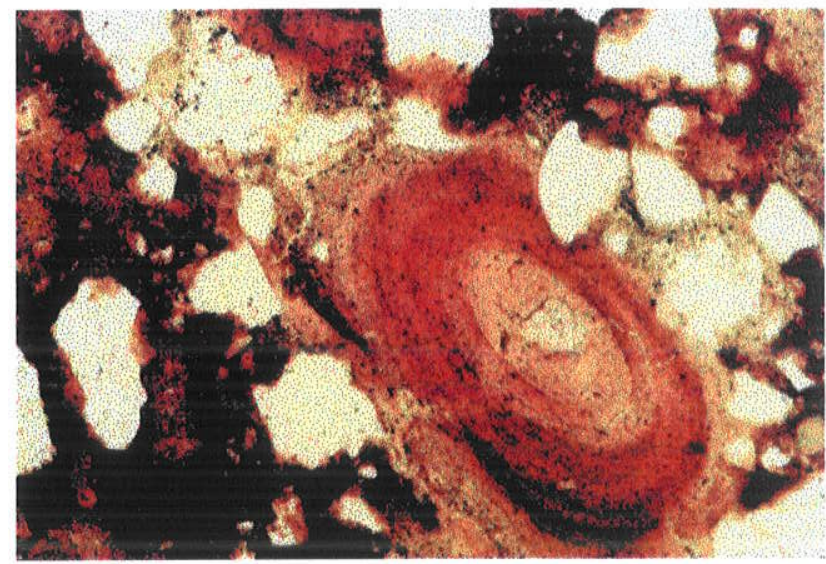

Figura V.14 - Fotomicrografia (Luz natural) Cavidade preenchida por material argilo ferruginoso, formando estrutura concêntrica (ferriargilan zonado), indicativa de segregação de ferro e argila (aresta horizontal =1,39 $\mathrm{mm}$ ). 


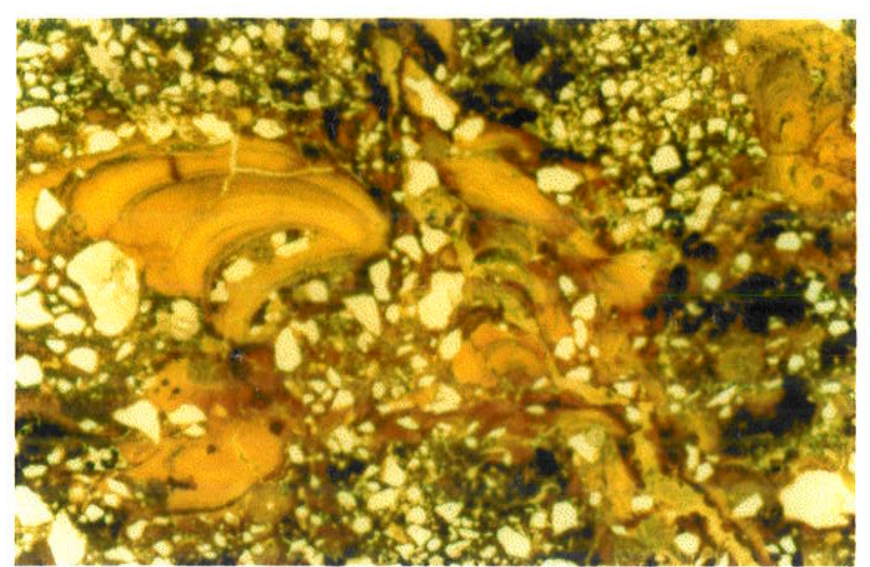

Figura V.15 - Fotomicrografia (Luz natural) Estrutura de preenchimento tipo Liesegang com feições de fragmentação de ferriargilans e redeposição de hidróxidos de ferro (aresta horizontal $=5,3 \mathrm{~mm}$ ).

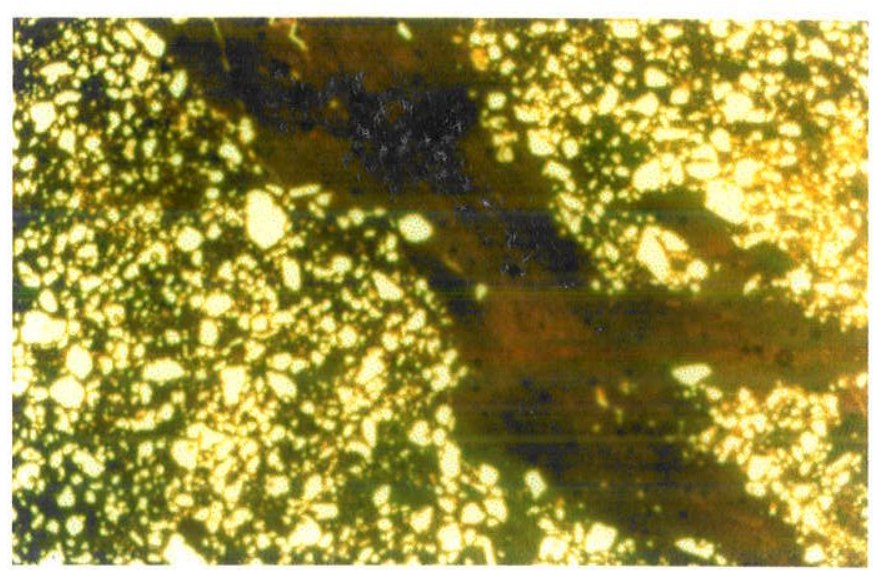

Figura V.16 - Fotomicrografia (Luz natural) Aspecto geral do plasma da crosta, exibindo fissura preenchida por hidróxidos de ferro (aresta horizontal $=5,3 \mathrm{~mm}$ ).

\section{Determinações em DRX}

Para as determinações em DRX dos materiais provenientes do afloramento da Vila Madalena, foram separadas 2 amostras compostas; uma representativa das amostras da matriz (VMM) e outra das amostras das crostas (VMC).

Através dos espectros, foi possível a identificação de quartzo, biotita, argila do grupo da caolinita, hematita, goethita e ilmenita. Nota-se uma intensidade maior dos picos de quartzo e caolinita na amostra da matriz, quando comparado com a amostra das crostas. (Figuras V.17 e V.18).

De um modo geral, os resultados obtidos para as duas amostras foram semelhantes. 


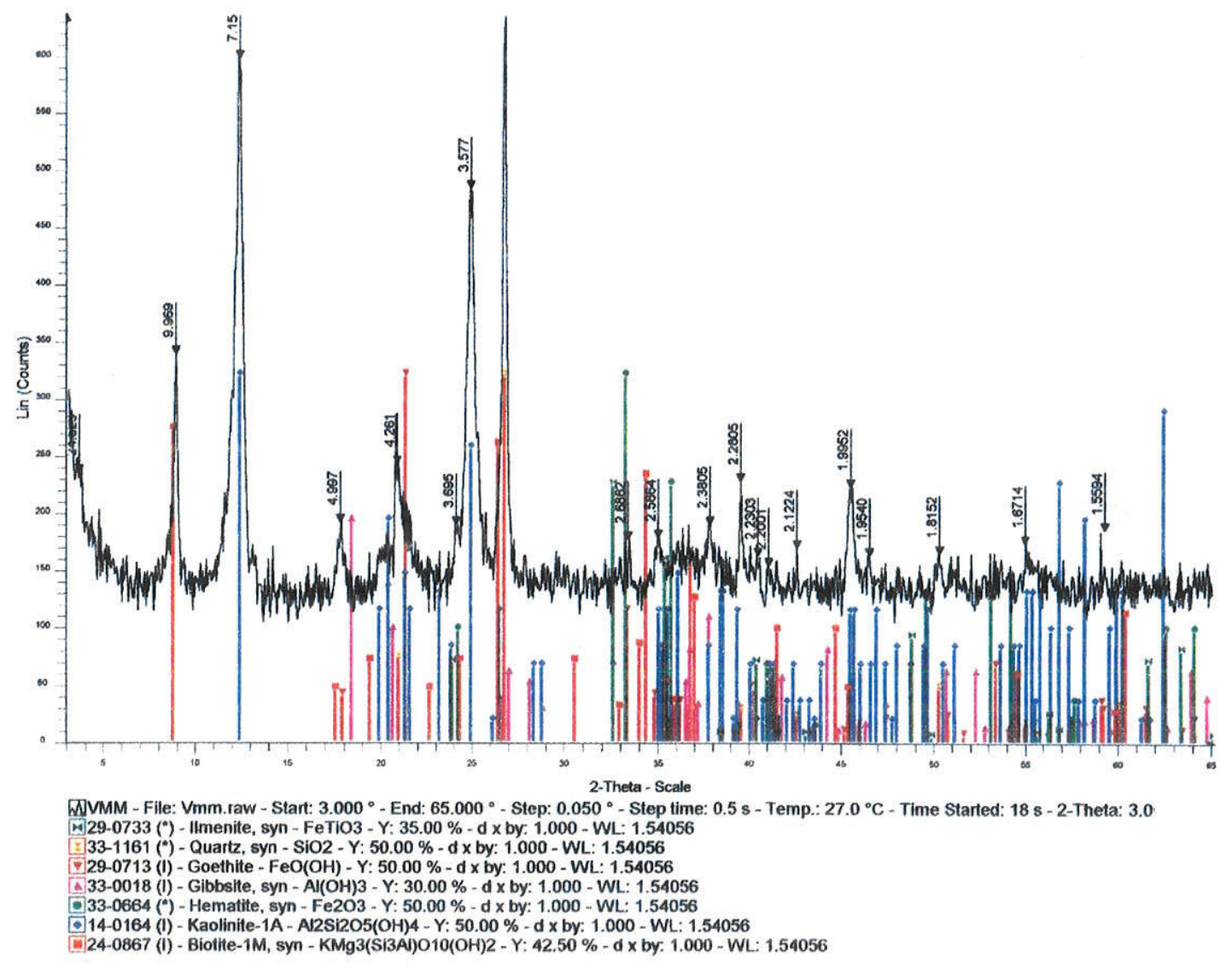

Figura V.17 - Resultados da análise por DRX da amostra da matriz (VMM) - Vila Madalena

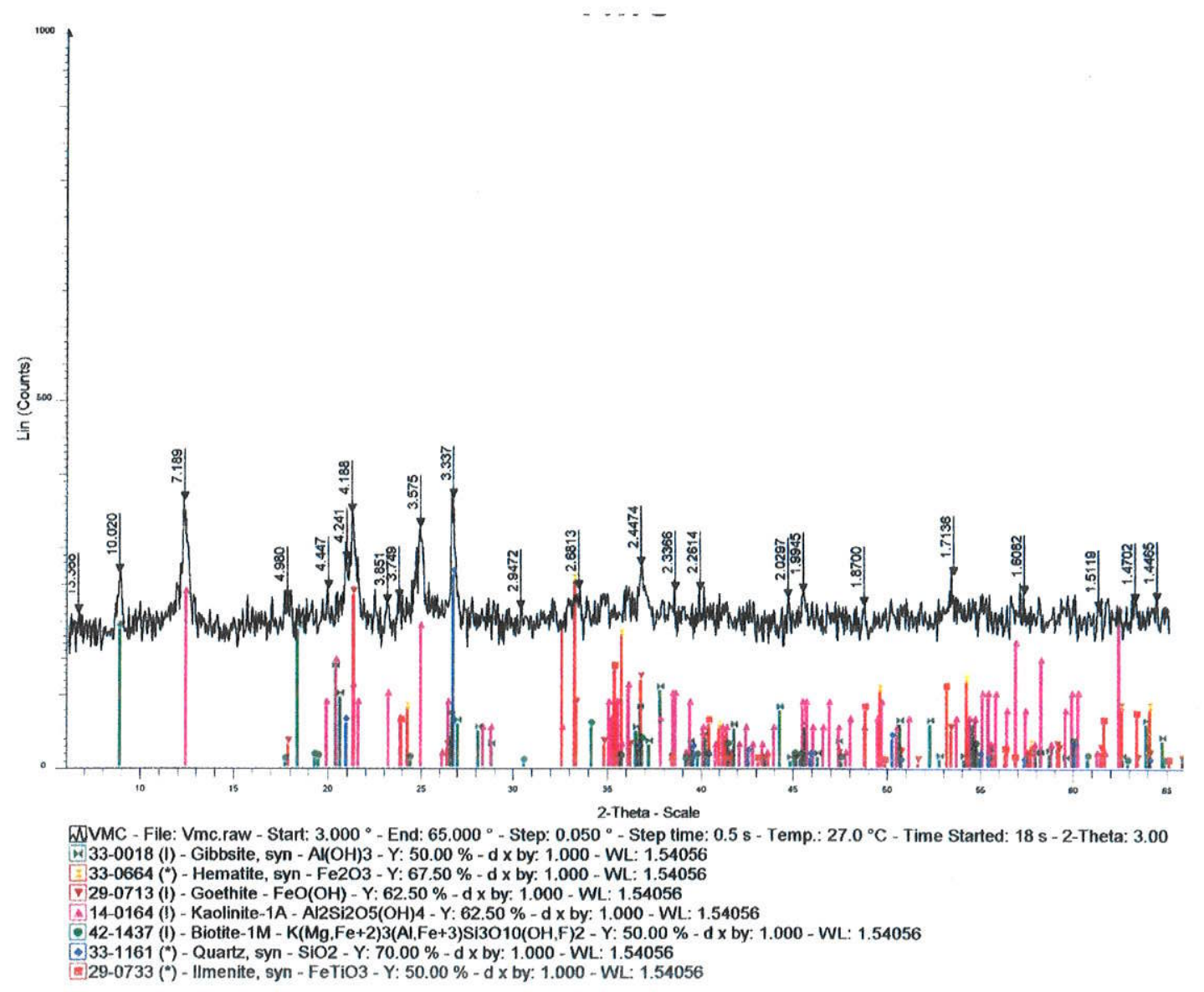

Figura V.18 - Resultados da análise por DRX da amostra da crosta (VMC) - Vila Madalena 
A análise de minerais pesados seguiu o procedimento já descrito no item Determinações em DRX deste capítulo, para preparação de duas amostras compostas (matriz e crosta). Estas amostras foram peneiradas a 16, 35, 100 e 200 mesh. A análise de minerais pesados foi realizada em cada uma destas frações.

Nas amostras do afloramento da Vila Madalena, este mesmo tipo de análise apresentou a seguinte assembléia mineralógica e estruturas associadas:

Quartzo (QTZ) - Fragmentos hialinos a branco acinzentados, angulares.

Agregados foscos vermelhos (AFV) - Fragmentos vermelho-acastanhados, arredondados, magnéticos.

Agregados foscos ocre (AFO) - Fragmentos ocre a castanho amarelados, arredondados.

Turmalina (TUR) - Fragmentos angulares, prismáticos, de coloração âmbar a negra.

Rutilo (RUT) - Fragmentos prismáticos, de coloração vermelha, amarela e incolor.

Zircão (ZIR) - Fragmentos angulares prismáticos, incolores a rosados.

Anatásio (ANA) - Fragmentos angulares, azulados, de brilho perláceo.

Estaurolita (EST) - Fragmentos anhedrais, angulares, de coloração caramelo, vítreos, magnéticos.

IImenita (ILM) - Fragmentos angulares negros, de brilho submetálico, tabulares, magnéticos.

Efetuou-se também, análise mineralógica semi-quantitativa da porcentagem em peso para as assembléias mineralógicas, identificadas nas frações analisadas das amostras da matriz (VMM) e das crostas (VMC).

Os resultados obtidos nestas análises encontram-se nas tabelas V.2 $\Theta$ V.3. 
Foi notado nestas amostras uma similaridade composicional de minerais pesados, com exceção do rutilo e do anatásio presentes como traço somente na amostra da matriz.

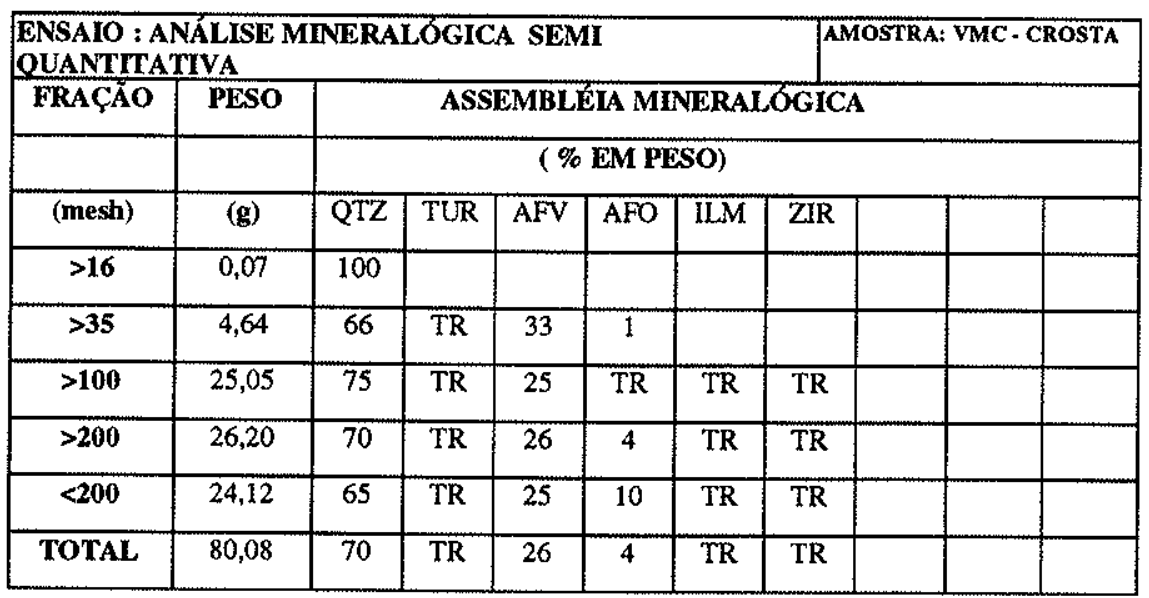

Tabela V.2: Resultados da análise mineralógica semi quantitativa dos minerais pesados para a amostra das crostas (Afloramento da Vila Madalena - Área - 2).

\begin{tabular}{|c|c|c|c|c|c|c|c|c|c|c|c|}
\hline \multicolumn{8}{|c|}{ ENSAIO : ANÁLISE MINERALOGICA SEMIQUANTTTATIVA } & \multicolumn{4}{|c|}{ AMOSTRA: VMM-MATRR } \\
\hline \multirow[t]{2}{*}{ FRACAOO } & PESO & \multicolumn{10}{|c|}{ ASSEMBLEIA MINERALÓGICA } \\
\hline & & \multicolumn{10}{|c|}{ ( \% EM PESO) } \\
\hline (mesh) & (g) & QTZ & TUR & AFV & $\mathrm{AFO}$ & EST & ILM & ZIR & RUT & ANA & \\
\hline$>16$ & 0,01 & 80 & 20 & & & & & & & & \\
\hline$>35$ & 4,16 & 95 & TR & 1 & 4 & TR & TR & & & & \\
\hline$>100$ & 35,17 & 95 & 1 & TR & 4 & TR & TR & TR & TR & $\mathrm{TR}$ & \\
\hline$>200$ & 32,90 & 96 & 2 & $\mathrm{TR}$ & 1 & TR & 1 & $\mathrm{TR}$ & TR & TR & \\
\hline$<200$ & 13,62 & 92 & TR & $\mathrm{TR}$ & 7 & & 1 & TR & TR & $\mathrm{TR}$ & \\
\hline TOTAL & 85,86 & 95 & 1 & TR & 3 & $\mathrm{TR}$ & 1 & TR & TR & $\overline{\mathrm{TR}}$ & \\
\hline
\end{tabular}

Tabela V.3: Resultados da análise mineralógica semi quantitativa dos minerais pesados para a amostra da matriz (Afloramento da Vila Madalena - Área - 2). 


\section{Comportamento Químico dos Elementos}

\section{Análises Químicas Totais}

O comportamento químico dos elementos maiores ( $\mathrm{Si}, \mathrm{Al}$ e $\mathrm{Fe}$ ), ao longo dos perfis de amostragem, indica uma maior concentração de ferro nas crostas (amostras VMC) e de sílica na matriz (amostras VMM). Não foram observadas grandes variações na porcentagem de alumínio entre os materiais analisados (matriz x crostas), nem ao longo dos perfis (Figura V.19). Este comportamento é comprovado pelos diagramas geoquímicos discriminativos, os quais exibem dois agrupamentos distintos; um das amostras da matriz e o outro das amostras das crostas (Figuras V.20, diagrama $\mathrm{SiO}_{2} \mathrm{x}$ $\mathrm{Al}_{2} \mathrm{O}_{3}$ e V.21 diagrama $\mathrm{SiO}_{2} \times \mathrm{Fe}_{2} \mathrm{O}_{3}$ ).

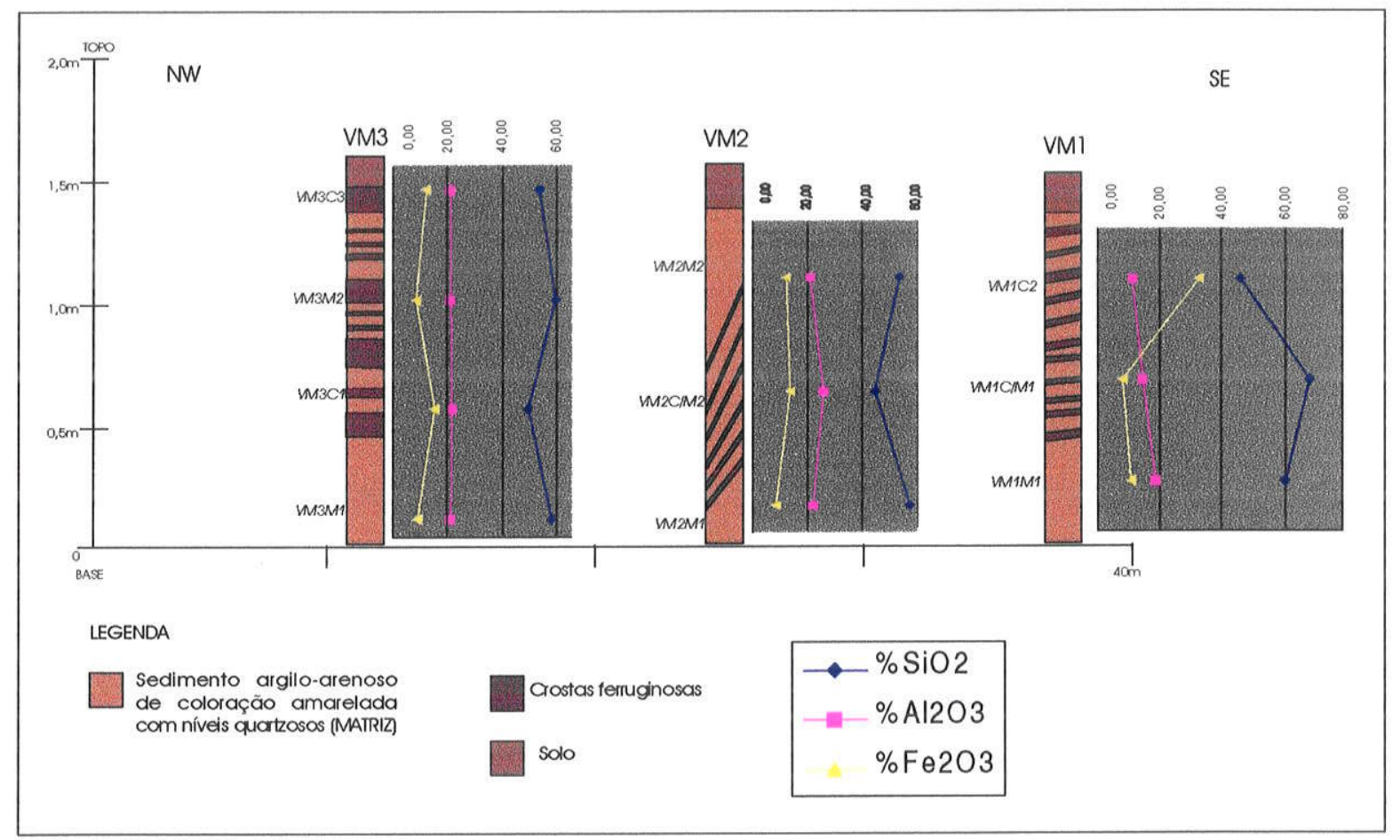

Figura V.19 - Comportamento geoquímico dos elementos $\mathrm{Si}, \mathrm{Al}$ e do Fe ao longo dos perfis estudados (afloramento da Vila Madalena - Área 2). 


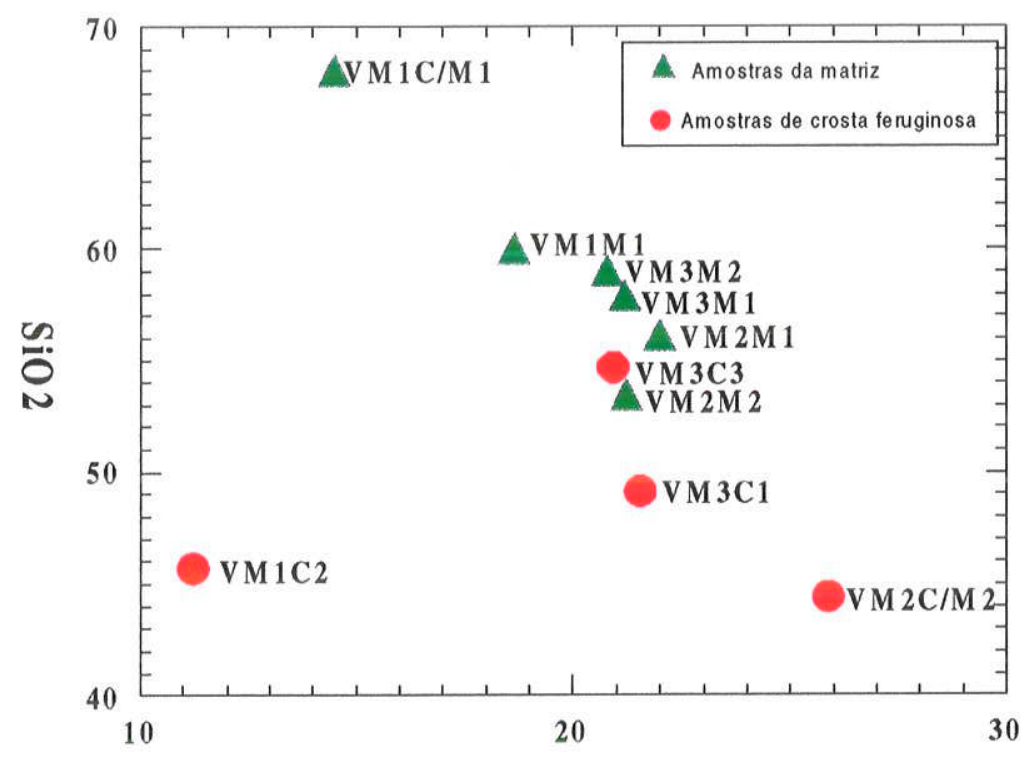

A1203

Figura V.20 - Diagrama geoquímico discriminativo $\mathrm{Fe}_{2} \mathrm{O}_{3} \times \mathrm{SiO}_{2}(\%)$, exibindo a distribuição dos campos de agrupamento das amostras (crostas e matriz), em função do comportamento geoquímico dos elementos (Vila Madalena - Área 2).

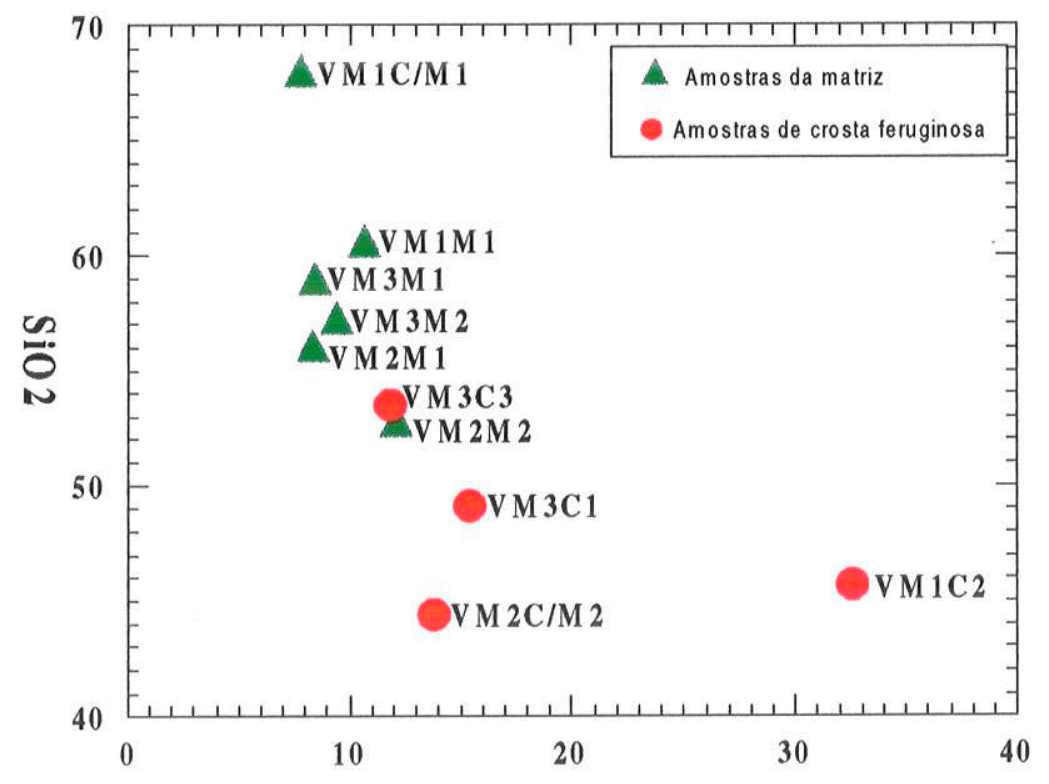

Fe203

Figura V.21 - Diagrama geoquímico discriminativo $\mathrm{Fe}_{2} \mathrm{O}_{3} \times \mathrm{Al}_{2} \mathrm{O}_{3}(\%)$, exibindo a distribuição dos campos de agrupamento das amostras (crostas e matriz), em função do comportamento geoquímico dos elementos. (Vila Madalena - Área 2). 
Os elementos alcalinos ( $\mathrm{Ca}, \mathrm{K}$, $\mathrm{Na}$ e $\mathrm{Mg}$ ) ocorrem em porcentagens menores principalmente nas amostras da matriz. O titânio permanece estável ao longo dos perfis, ocorrendo em concentrações equivalentes, tanto nas amostras da matriz como nas amostras das crostas (Figuras V.22 diagrama $\mathrm{SiO}_{2} \times$ Alcalinos e V.23 diagrama $\mathrm{SiO}_{2} \times$ $\left.\mathrm{TiO}_{2}\right)$.

Não foi possível identificar nos diagramas construídos, trends de evolução geoquímica exibindo relações de enriquecimento ou empobrecimento progressivo de um ou mais elementos nos horizontes dos perfis analisados.

Os resultados obtidos nas análises químicas totais para as amostras do afloramento da Vila Madalena encontram-se na tabela V.4:

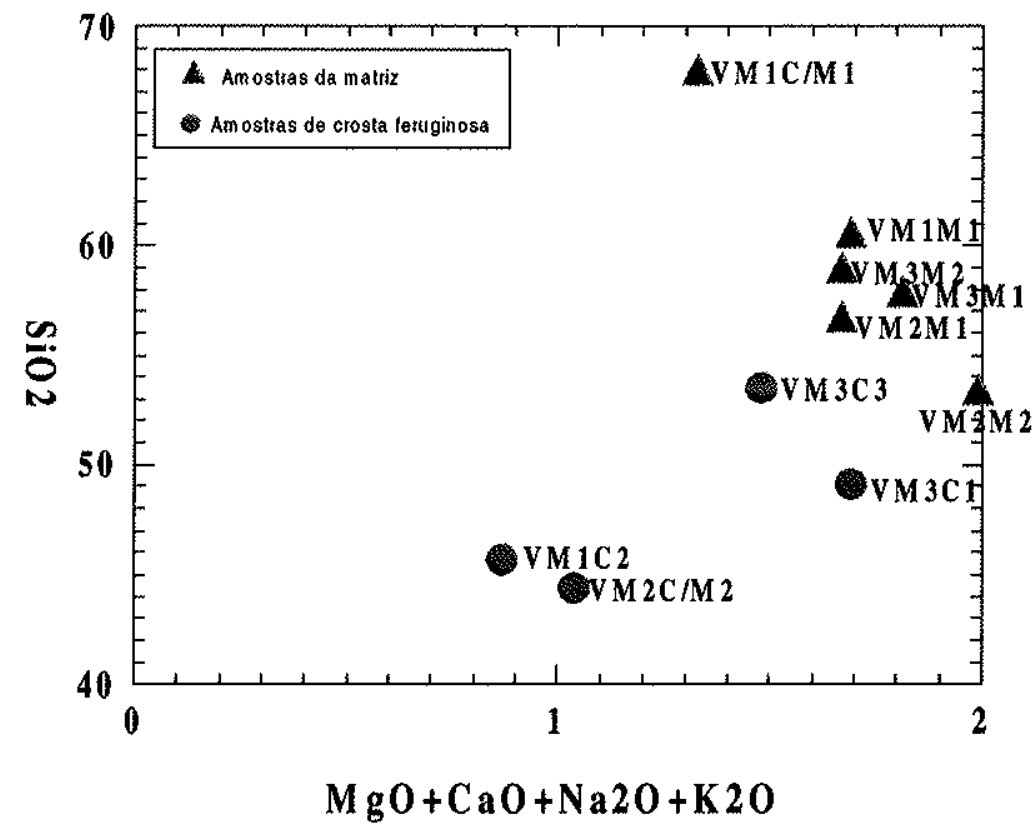

Figura V.22 - Diagrama geoquímico discriminativo $\mathrm{SiO}_{2} \times$ Alcalinos (\%), exibindo a distribuição dos campos de agrupamento das amostras (crostas e matriz), em função do comportamento geoquímico dos elementos. (Vila Madalena - Área 2). 


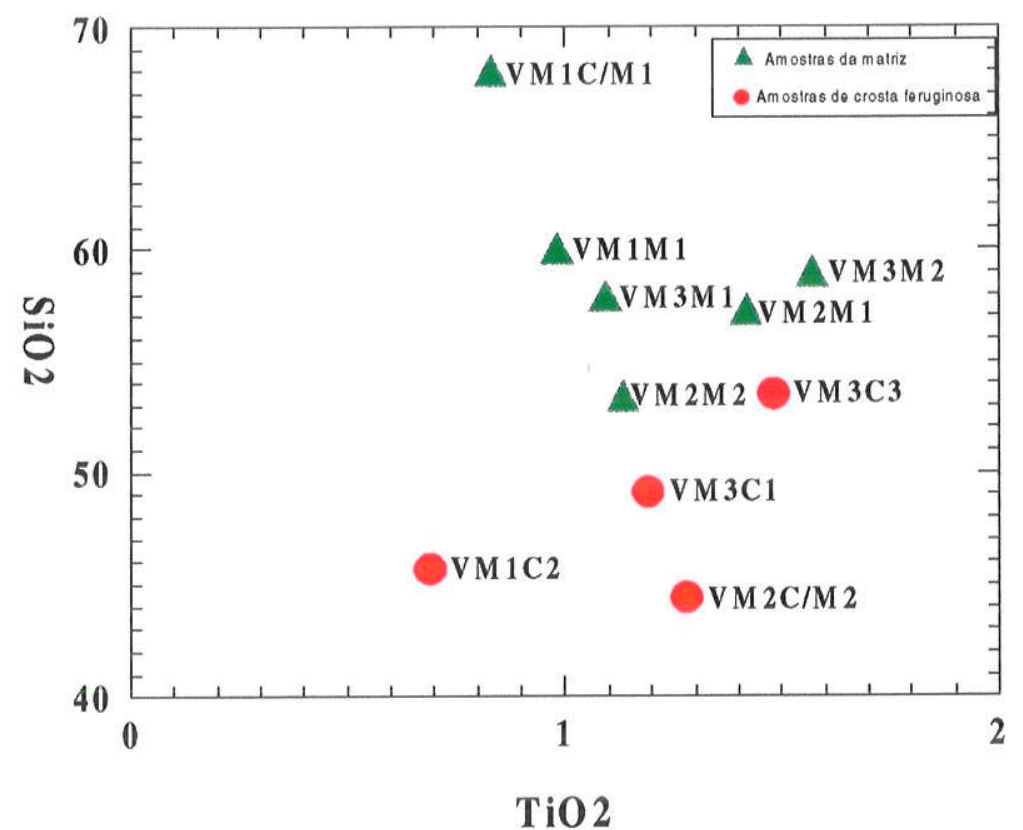

Figura V.23 - Diagrama geoquímico discriminativo $\mathrm{SiO}_{2} \times \mathrm{TiO}_{2}(\%)$, exibindo a distribuição dos campos de agrupamento das amostras (crostas e matriz), em função do comportamento geoquímico dos elementos. (Vila Madalena - Área 2).

\begin{tabular}{|c|c|c|c|c|c|c|c|c|c|c|}
\hline AMOSTRA & VM1M1 & VM1C/M1 & VM1C2 & VM2M1 & VM2C/M2 & VM2M2 & VM3M1 & VM3C1 & VM3M2 & VM3C3 \\
\hline$\% \mathrm{SiO}_{2}$ & 60,01 & 68,03 & 45,71 & 57,30 & 44,44 & 53,45 & 57,90 & 49,15 & 59,01 & 53,53 \\
\hline$\% \mathrm{Al}_{2} \mathrm{O}_{3}$ & 18,65 & 14,47 & 11,20 & 21,97 & 25,89 & 21,21 & 21,17 & 21,55 & 20,79 & 20,90 \\
\hline$\% \mathrm{Fe}_{2} \mathrm{O}_{3}$ & 10,67 & 7,79 & 32,61 & 8,35 & 13,83 & 12,10 & 8,74 & 15,40 & 8,39 & 11,85 \\
\hline$\% \mathrm{MgO}$ & 0,17 & 0,15 & 0,10 & 0,18 & 0,15 & 0,19 & 0,19 & 0,19 & 0,17 & 0,16 \\
\hline$\% \mathrm{CaO}$ & 0,05 & 0,12 & 0,05 & 0,05 & 0,04 & 0,03 & 0,05 & 0,06 & 0,03 & 0,05 \\
\hline$\% \mathrm{Na}_{2} \mathrm{O}$ & 0,09 & 0,07 & 0,05 & 0,09 & 0,05 & 0,09 & 0,08 & 0,08 & 0,07 & 0,07 \\
\hline$\% \mathrm{~K}_{2} \mathrm{O}$ & 1,38 & 0,99 & 0,67 & 1,35 & 0,80 & 1,68 & 1,49 & 1,51 & 1,40 & 1,20 \\
\hline$\% \mathrm{P}_{2} \mathrm{O}_{5}$ & 0,02 & 0,02 & 0,02 & 0,05 & 0,04 & 0,03 & 0,03 & 0,03 & 0,03 & 0,04 \\
\hline$\% \mathrm{MnO}$ & 0,01 & 0,01 & 0,01 & 0,02 & 0,01 & 0,02 & 0,02 & 0,02 & 0,02 & 0,02 \\
\hline$\% \mathrm{TiO}_{2}$ & 0,98 & 0,83 & 0,69 & 1,42 & 1,28 & 1,19 & 1,09 & 1,19 & 1,57 & 1,48 \\
\hline$\%$ P.F. & 7,79 & 7,33 & 8,78 & 9,24 & 12,81 & 9,05 & 8,96 & 9,75 & 8,36 & 9,34 \\
\hline$\%$ Total & 99,82 & 99,80 & 99,88 & 100,02 & 99,33 & 99,05 & 99,72 & 98,93 & 99,86 & 98,66 \\
\hline$\% \mathrm{H}_{2} \mathrm{O}^{-}$ & 0,92 & 1,01 & 0,95 & 1,63 & 7,41 & 1,43 & 1,23 & 1,08 & 1,33 & 1,02 \\
\hline $\mathrm{Ba}(\mathrm{ppm})$ & 320 & 235 & 165 & 319 & 197 & 390 & 331 & 337 & 325 & 279 \\
\hline $\mathrm{Cr}$ (ppm) & 57 & $<15$ & $<15$ & 114 & 100 & 83 & 69 & 67 & 61 & 71 \\
\hline Ni (ppm) & $<15$ & $<15$ & $<15$ & $<15$ & $<15$ & $<15$ & $<15$ & 17 & 18 & 22 \\
\hline Sr (ppm) & 47 & 37 & 30 & 66 & 51 & 47 & 48 & 52 & 65 & 61 \\
\hline V (ppm) & 120 & 69 & 82 & 370 & 221 & 178 & 122 & 140 & 100 & 161 \\
\hline $\mathrm{Zr}(\mathrm{ppm})$ & 440 & 576 & 423 & 581 & 433 & 396 & 453 & 439 & 574 & 539 \\
\hline
\end{tabular}

Tabela V.4 - Resultados das análises químicas totais para as amostras coletadas nos perfis do Afloramento da Vila Madalena (Área-2). 
As análises em MEV/EDS de lâminas pertencentes ao afloramento da Vila Madalena confirmaram os resultados obtidos nas análises químicas totais, demonstrando que as mais altas concentrações de ferro são encontradas na região das crostas, composta basicamente de grãos de quartzo de tamanho variado, cimentados por material ferruginoso. A matriz que se intercala a estas crostas é composta, quase que essencialmente, por grãos de quartzo equigranulares, poucos cristais placóides de biotita e baixa concentração de ferro e alumínio no plasma (Figuras V.24 e V.25).

Análise pontual qualitativa em sequência, atravessando as regiões correspondentes a matriz e crosta (Figuras V.24 e V.25) demonstrou nitidamente aumento nas concentrações de ferro e alumínio, a medida que se avança para a região do plasma correspondente a crosta. A sillica, por sua vez, permanece em concentrações constantes ao longo da seção analisada, exceto na região de interface crosta/matriz, quando ocorre aumento significativo no teor de silício nesta região (Figuras V.26 a V.30).

Foram identificados vários fragmentos de grãos metálicos constituídos de titânio e ferro, disseminados nas lâminas analisadas (Figuras V.31 e V.32).

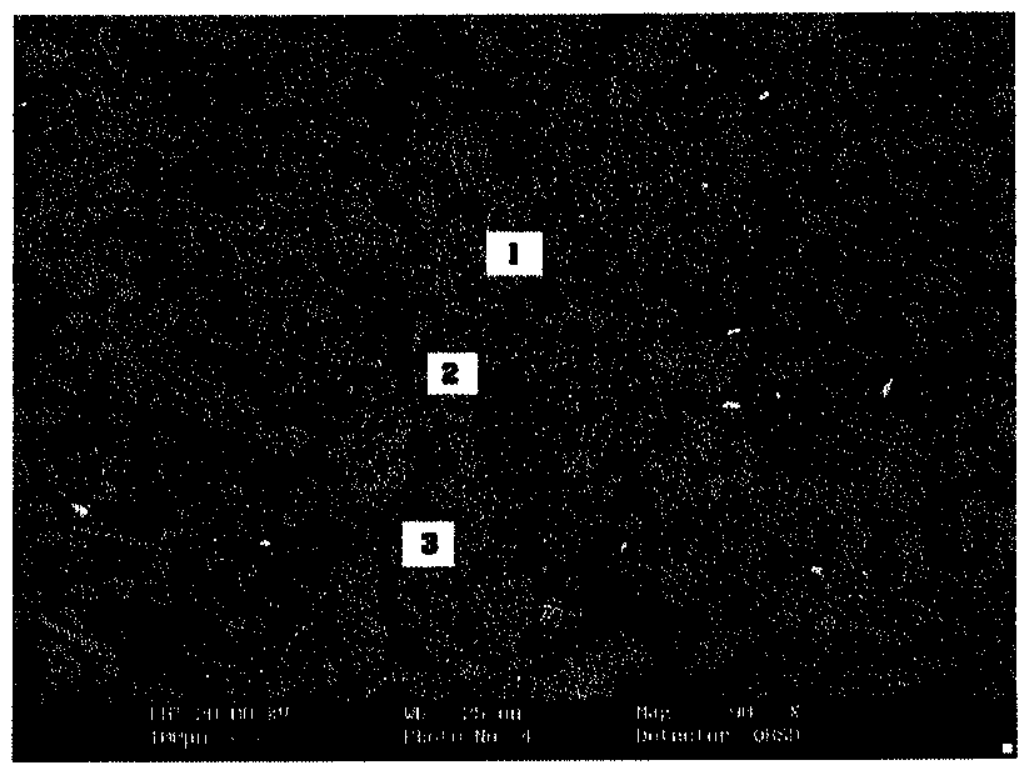

Figura V.24 - Imagem em MEV - Aspecto geral da matriz (Vila Madalena). 


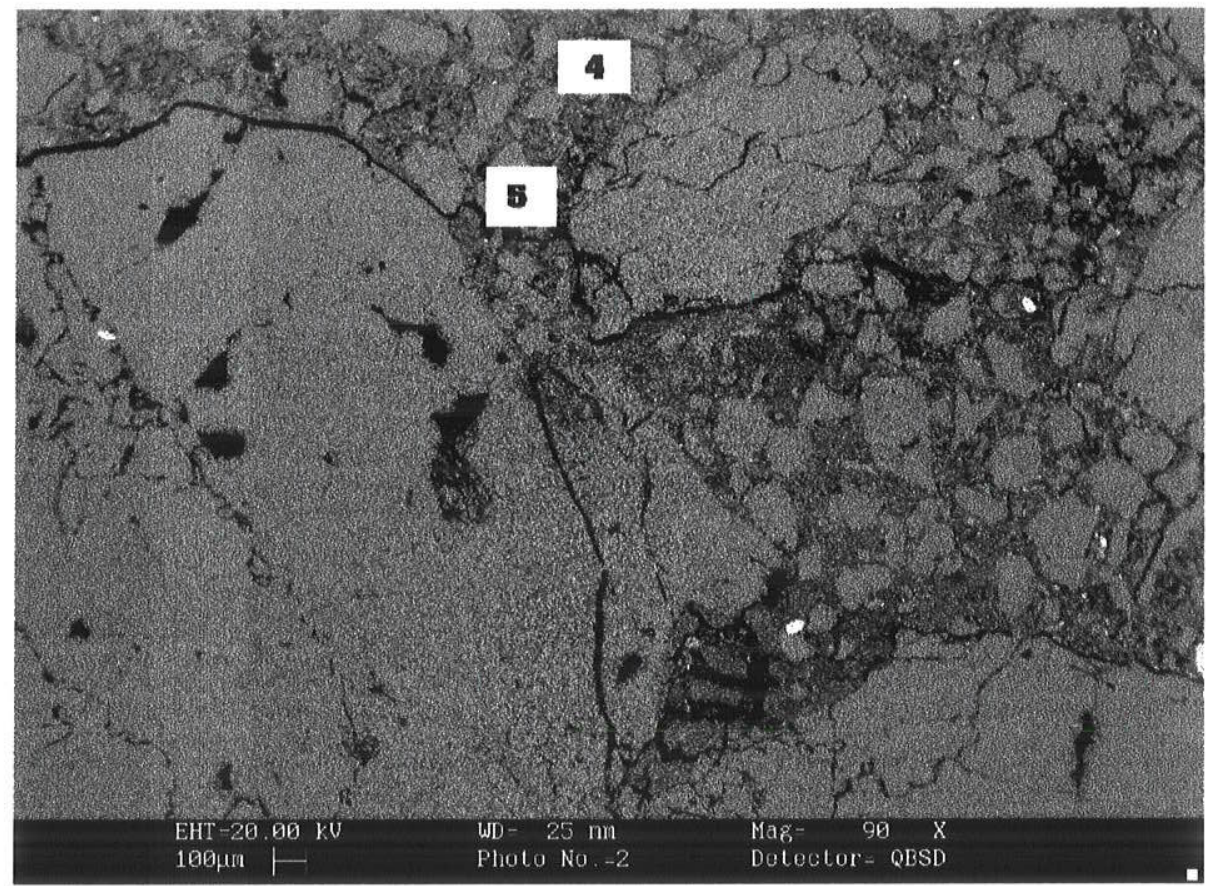

Figura V.25 - Imagem em MEV - Aspecto geral da crosta (Vila Madalena).

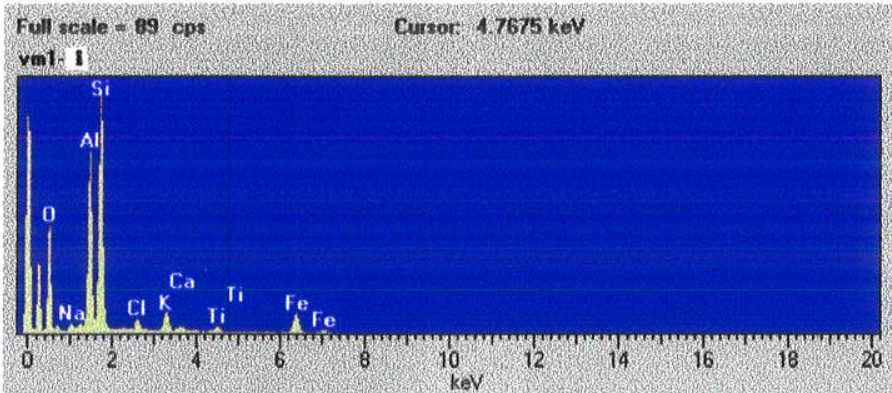

Figura V.26 - Espectro de EDS do ponto 1 da figura V.24, com análise qualitativa. Destacam-se principalmente os picos do silício (Si), do alumínio (Al) e do oxigênio $(\mathrm{O})$ (região da matriz), já os picos de ferro $(\mathrm{Fe})$, titânio $(\mathrm{Ti})$, potássio $(\mathrm{K})$, sódio $(\mathrm{Na})$, cálcio $(\mathrm{Ca})$ aparecem menos acentuados. O pico de cloro (Cl) provém da resina utilizada na impregnação dos materiais para a confecção das lâminas delgadas.

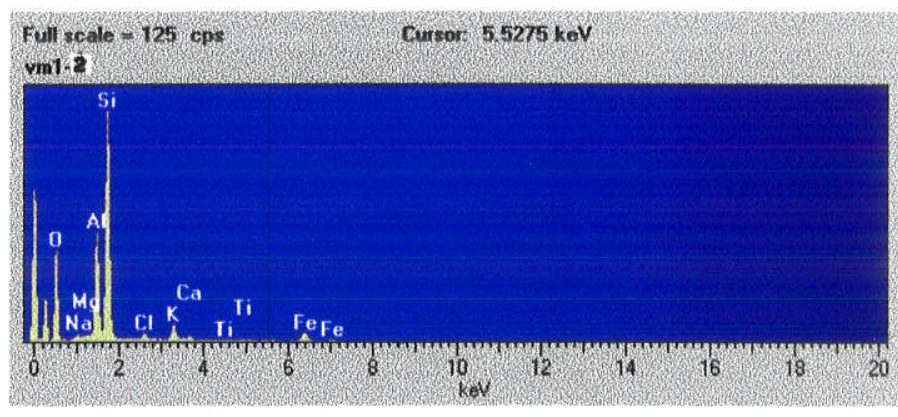

Figura V.27 - Espectro de EDS do ponto 2 da figura V.24, com análise qualitativa. Destacam-se principalmente os picos do silício (Si), do alumínio (Al) e do oxigênio $(\mathrm{O})$ (região da matriz), já os picos de ferro $(\mathrm{Fe})$, titânio $(\mathrm{Ti})$, potássio $(\mathrm{K})$, sódio $(\mathrm{Na})$, cálcio $(\mathrm{Ca})$ aparecem menos acentuados. O pico de cloro (Cl) provém da resina utilizada na impregnação dos materiais para a confecção das lâminas delgadas. 


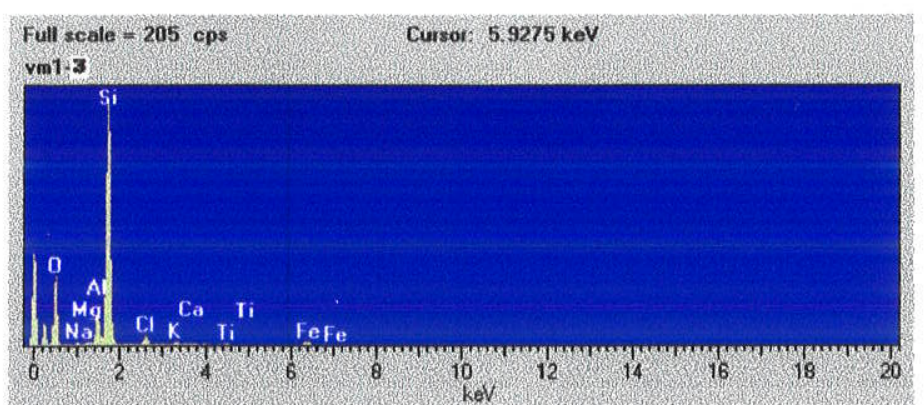

Figura V.28 - Espectro de EDS do ponto 3 da figura V.24, com análise qualitativa. Destacam-se principalmente os picos do silício ( $\mathrm{Si}$ ) e oxigênio (O) (região da matriz), já os picos de alumínio (Al), ferro $(\mathrm{Fe})$, titânio (Ti), potássio $(\mathrm{K})$, sódio $(\mathrm{Na})$, cálcio $(\mathrm{Ca})$, magnésio $(\mathrm{Mg})$ aparecem menos acentuados.
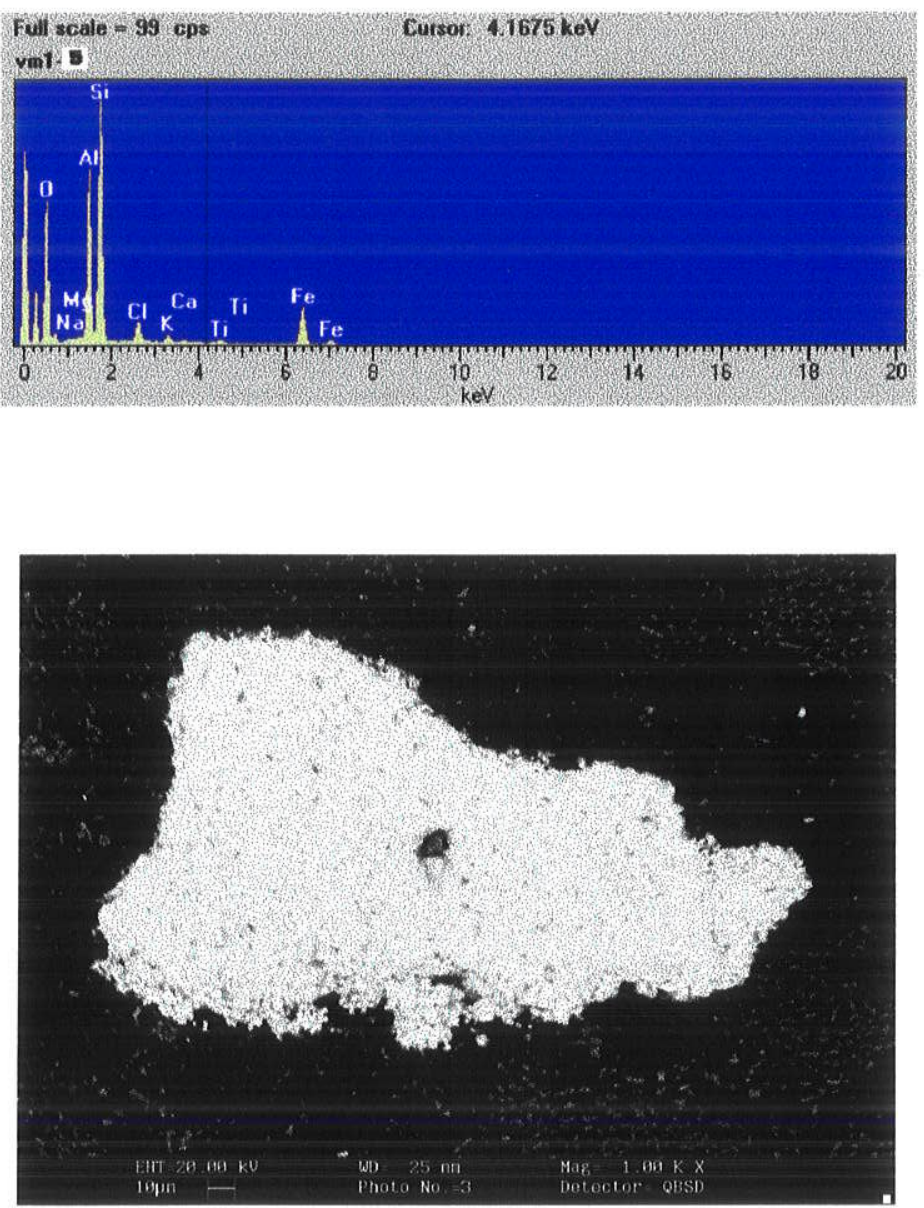

Figura V.31 - Imagem em MEV de grão metálico constituído principalmente de titânio e ferro.

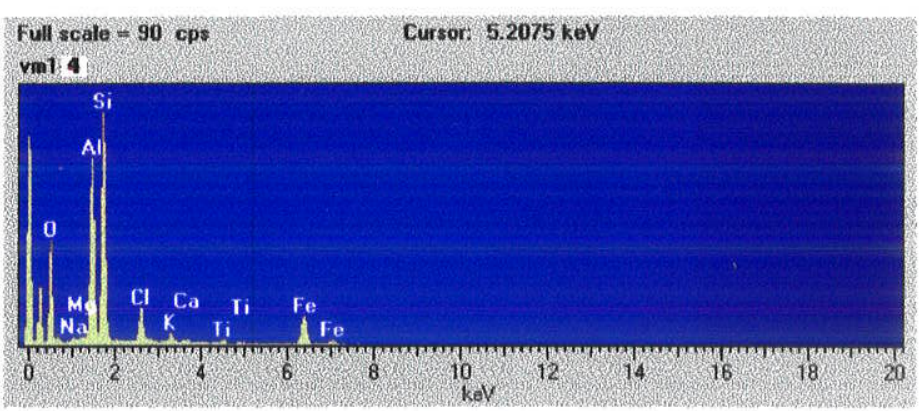

Figura V.29 - Espectro de EDS do ponto 4 da figura V.25, com análise qualitativa. Destacam-se principalmente os picos do silício (Si), alumínio (AI) e oxigênio (O). Nota-se a elevação dos picos de ferro (Fe) (região da crosta), já os picos de titânio (Ti), potássio $(\mathrm{K})$, sódio $(\mathrm{Na})$, cálcio $(\mathrm{Ca})$, magnésio $(\mathrm{Mg})$ aparecem menos acentuados. O pico de cloro (Cl) provém da resina utilizada na impregnação dos materiais para a confecção das lâminas delgadas.

Figura V.30 - Espectro de EDS do ponto 5 da figura V.25, com análise qualitativa. Destacam-se principalmente os picos do silício $(\mathrm{Si})$, alumínio (Al) e oxigênio $(\mathrm{O})$. Nota-se a elevação dos picos de ferro ( $\mathrm{Fe}$ ) (região da crosta), já os picos de titânio $(\mathrm{Ti})$, potássio $(\mathrm{K})$, sódio $(\mathrm{Na})$, cálcio $(\mathrm{Ca})$, magnésio $(\mathrm{Mg})$ aparecem menos acentuados. O pico de cloro (Cl) provém da resina utilizada na impregnação dos materiais para a confecção das lâminas delgadas.

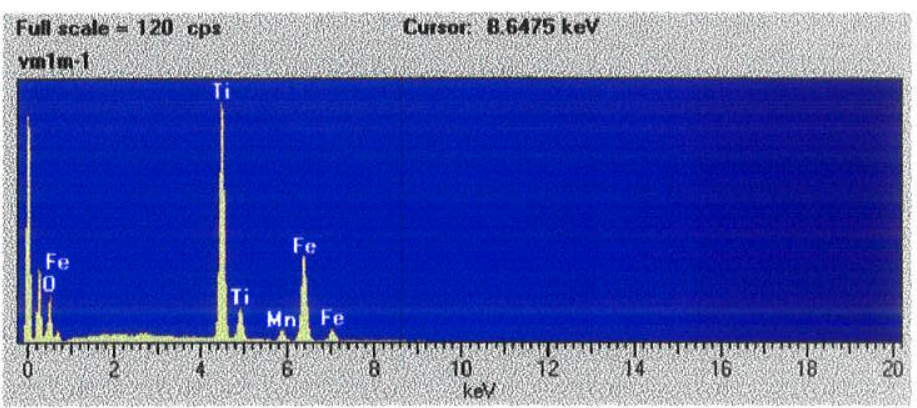

Figura V.32 - Espectro de EDS do grão metálico da figura V.31, com análise qualitativa. Destacam-se os picos do titânio (Ti), ferro (Fe) e manganês (Mn). 


\section{ESTRADA DOS ROMEIROS - PIRAPORA DO BOM JESUS (ÁREA - 3)}

\section{Caracterização Mineralógica dos Materiais}

\section{Caracterização Microscópica}

A observação microscópica das lâminas petrográficas dos materiais coletados da porção sem "dobras" e da porção com "dobras" do afloramento de Pirapora, permitiu a identificação de minerais primários, predominantemente representados pelo quartzo e litorelíquias, constituídas por fragmentos de filito, quartzito e restos de couraça ferruginosa.

Os grãos de quartzo apresentam-se angulosos, semi-angulosos e arredondados, com dimensões variadas e com feições de corrosão. Muitos destes grãos apresentam-se microfissurados. Estas fissuras apresentam-se preenchidas por hidróxidos de ferro (Figura V.33).

As litorelíquias são geralmente angulosas, placóides e algumas vezes se encontram cortadas por fissuras (Figuras V.34 e V.35). Os fragmentos de couraça são arredondados, escuros, com vários grãos de quartzo inclusos e ocorrem principalmente nos materiais da porção sem "dobras" do afloramento (Figura V.36).

Os materiais, tanto da porção do afloramento sem "dobras" como da porção com "dobras", apresentam dois plasmas distintos. Um primeiro constituído, predominantemente, por óxidos e hidróxidos de ferro (plasma goethítico). Este possui cor vermelha, sob luz natural e marrom, sob luz polarizada.

O outro plasma é mais argiloso (caolinítico) e apresenta cor amarela clara, sob luz natural e marrom amarelada, sob luz polarizada.

Nos materiais correspondentes a porção sem "dobras", o plasma caolinítico ocorre de forma dispersa como nodulações esbranquiçadas no interior do plasma avermelhado (goethítico), não sendo possivel a definição de zonas ou horizontes individualizados, constituídos predominantemente por um destes plasmas (Figura V.37). 
Nos materiais correspondentes a porção do afloramento com "dobras", observou-se que o plasma avermelhado (goethítico) predomina na região das crostas ferruginosas, com algumas intercalações e nódulos constituídos por material argiloso amarelado (caolinítico). O material que intercala as crostas (matriz) é constituído predominantemente pelo plasma amarelado caolinítico (Figuras V.38 e V.39).

Indicações de remobilização de hidróxido de ferro são comuns, tanto no plasma correspondente às crostas como no plasma da matriz. Estas indicações também são comuns nos materiais pertencentes à porção do afloramento sem "dobras". Apresentam-se na forma de fissuras preenchidas por plasma goethítico de diferentes gerações ou por plasma caolinítico.

Outras indicações de remobilização de hidróxido de ferro encontradas foram cutanes preenchidos por material argilo-ferruginoso (ferriargilans), feições de preenchimento concêntrico, zonas exibindo segregação de ferro formando bandamento tipo Liesegang, nodulações e concentrações plásmicas (Figuras V.38 e V.40 a V.46).

De uma maneira geral, a porosidade do plasma na região das crostas é maior do que do plasma da matriz. Em alguns casos a porosidade é praticamente inexistente na região das crostas, onde predomina massa compacta constituída por goethita cimentando raros grãos de quartzo. 


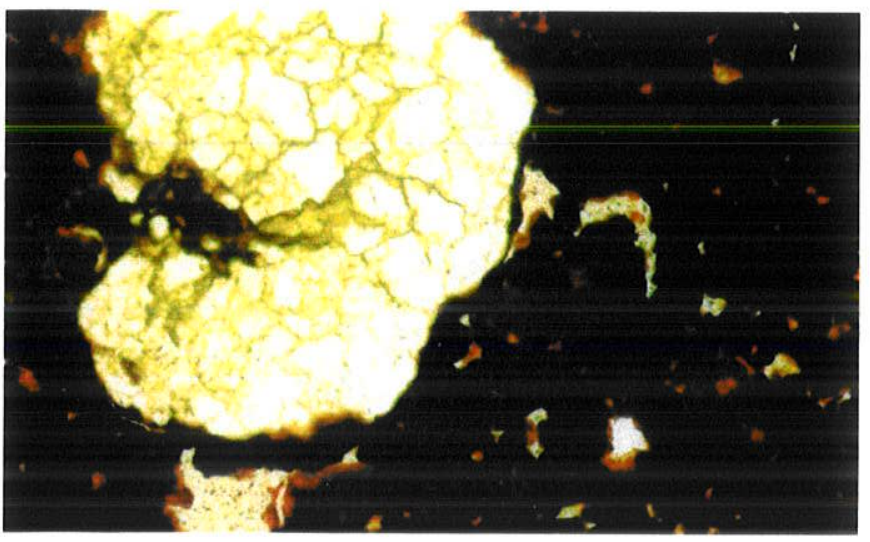

Figura V.33 - Fotomicrografia (luz natural) de grão de quartzo envolto em plasma goethítico, parcialmente corroído e microfissurado, com fissura preenchida por hidróxido de ferro (aresta horizontal = $1,39 \mathrm{~mm})$.

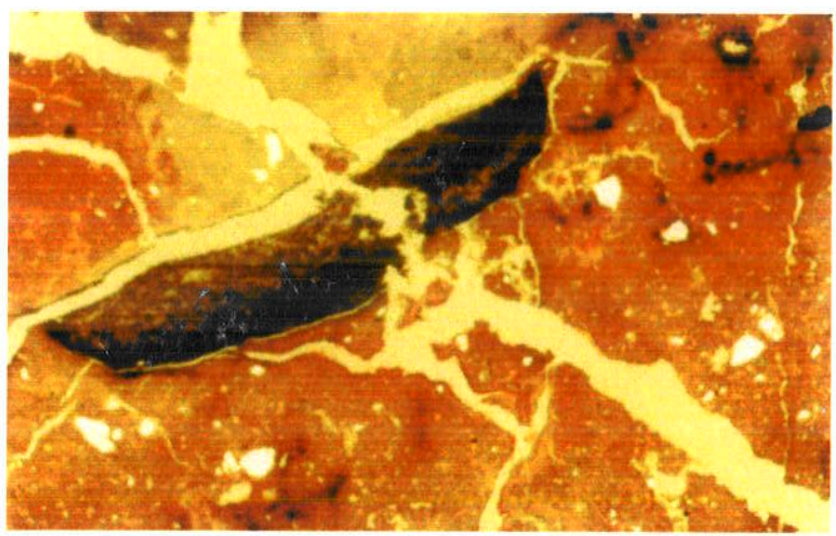

Figura V.35 - Fotomicrografia (luz natural) de litorelíquia (fragmento de filito), cortada por fissura (região da crosta) (a direita) (aresta horizontal $=5,3$ $\mathrm{mm})$.

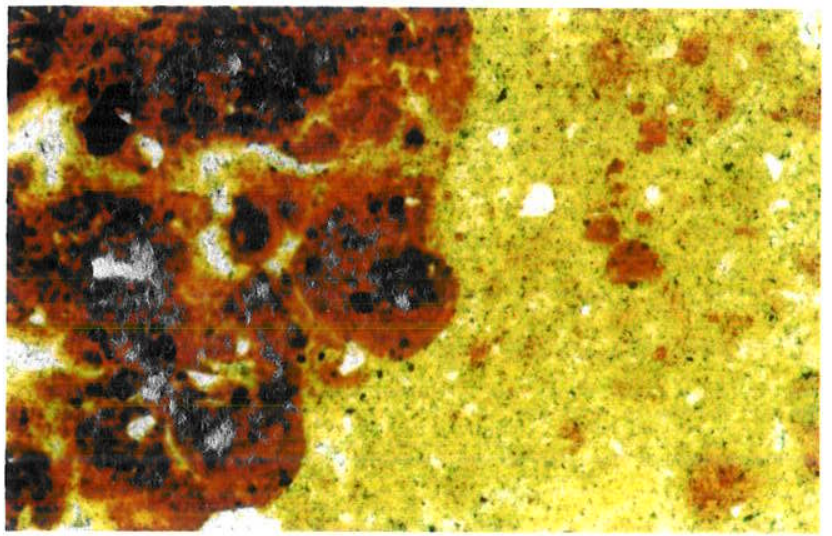

Figura V.37 - Fotomicrografia (luz natural) exibindo região de contato entre o plasma caolinítico da matriz (plasma amarelado a direita) e o plasma goethítico da crosta (plasma avermelhado a esquerda) (aresta horizontal $=5,3 \mathrm{~mm})$.

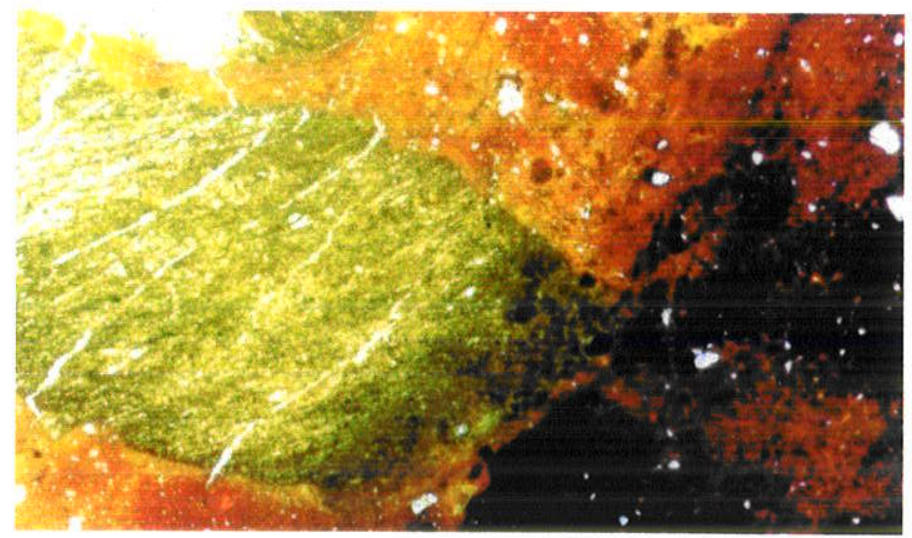

Figura V.34 - Fotomicrografia (luz natural) de litorelíquia (fragmento de quartzito), microfissurada no interior do plasma caolinítico (região da matriz). Destaca-se também o contato entre o plasma caolinítico da matriz (plasma amarelado a esquerda) e o plasma goethítico da crosta (plasma avermelhado a direita) (aresta horizontal $=5,3 \mathrm{~mm}$ ).

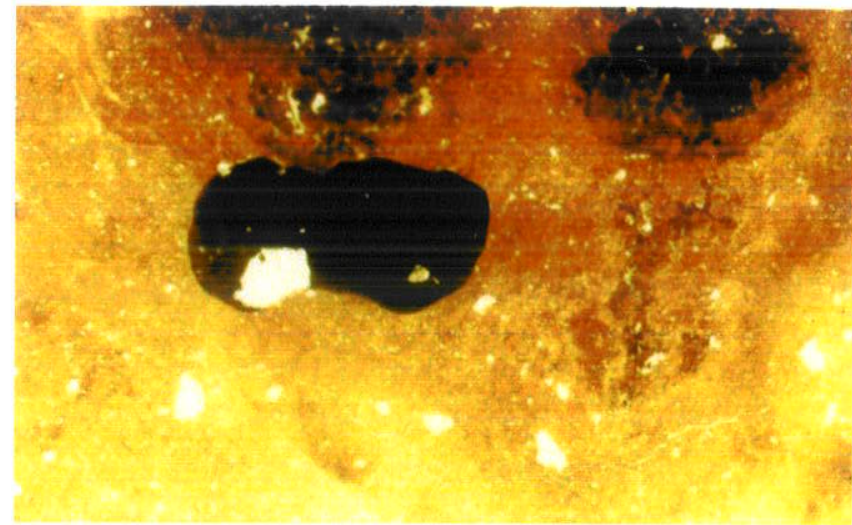

Figura V.36 - Fotomicrografia (luz natural) de fragmento de couraça ferruginosa no interior do plasma correspondente a porção do afloramento sem "dobras" (aresta horizontal = 5,3 mm).

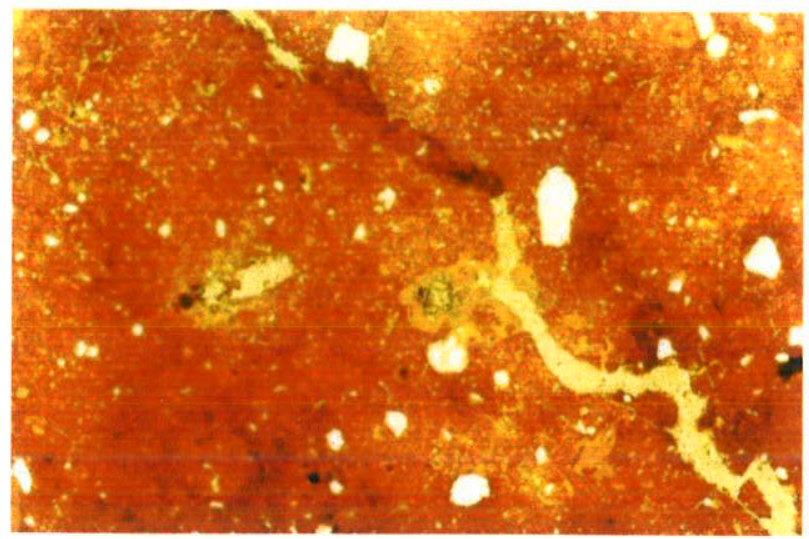

Figura V.38 - Fotomicrografia (luz natural) de fissura, parcialmente preenchida por hidróxidos de ferro, indicando remobilização de ferro nestes materiais (região da crosta) (aresta horizontal = $5,3 \mathrm{~mm})$. 

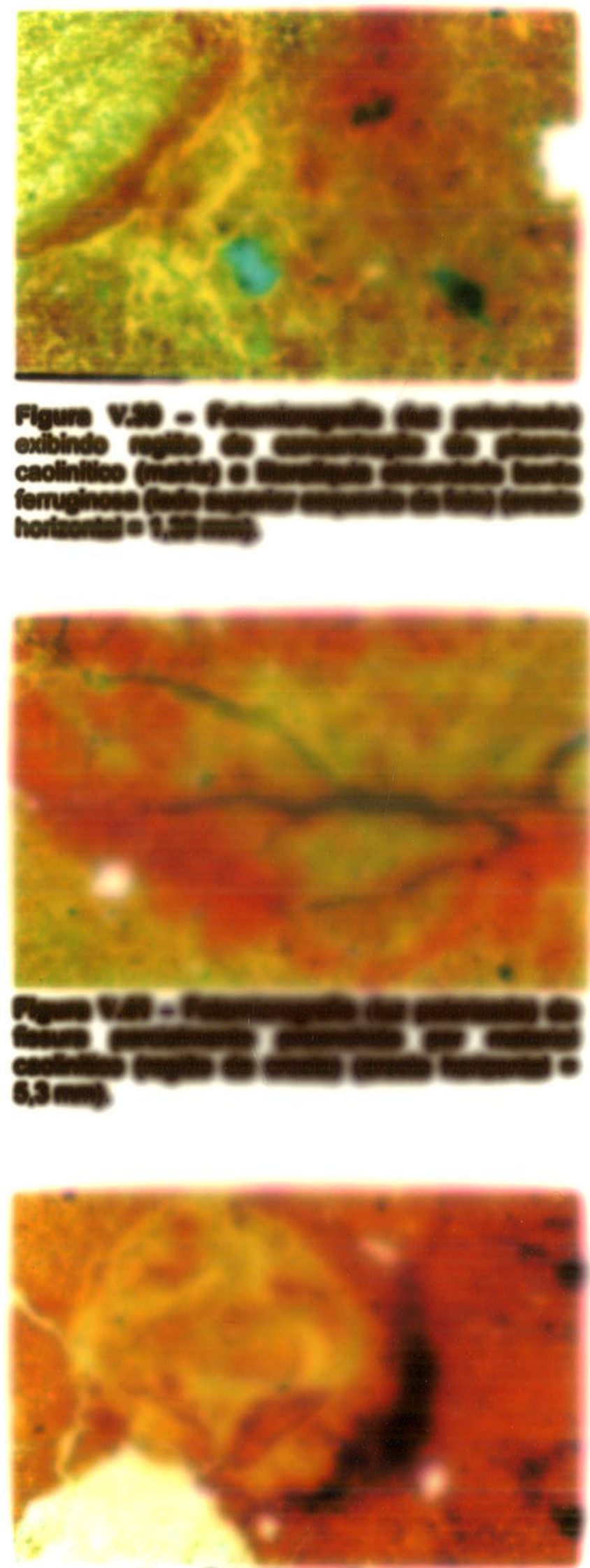

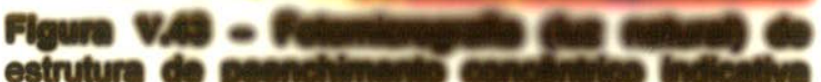

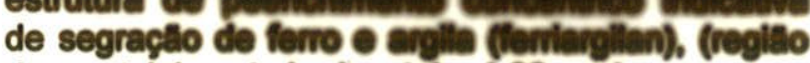
da crosta) (aresta horizontal = 1,39 mm).
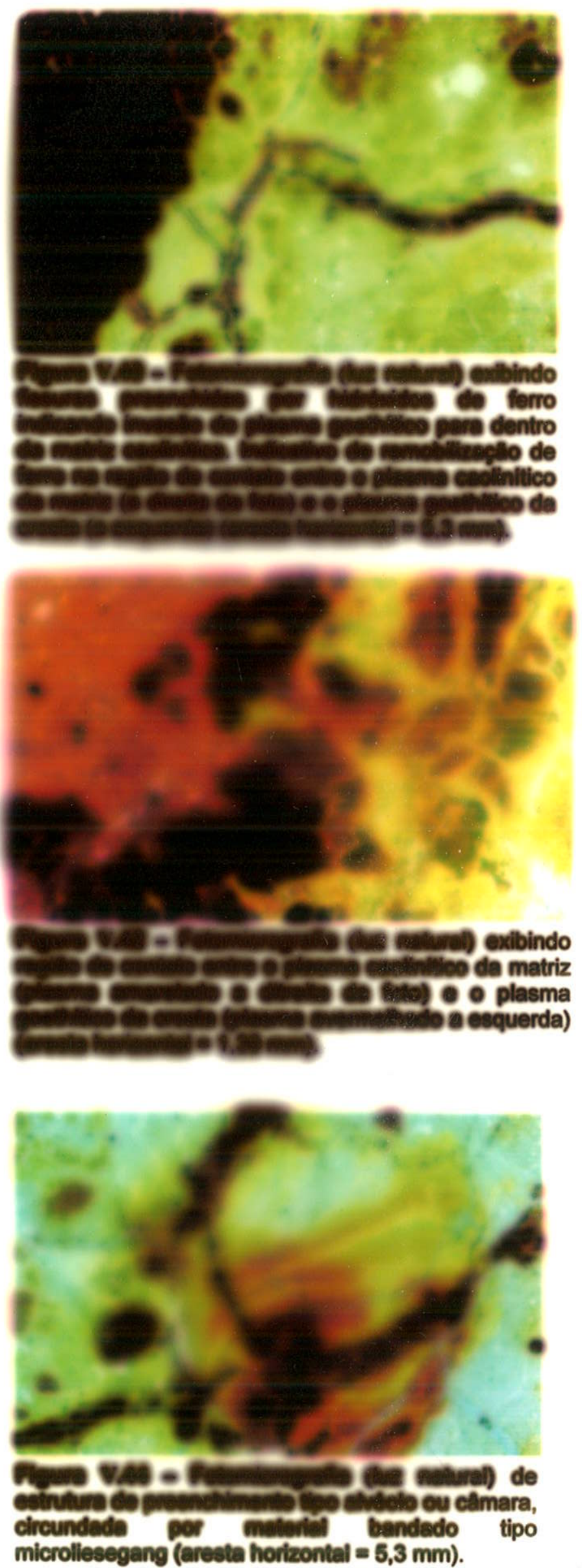


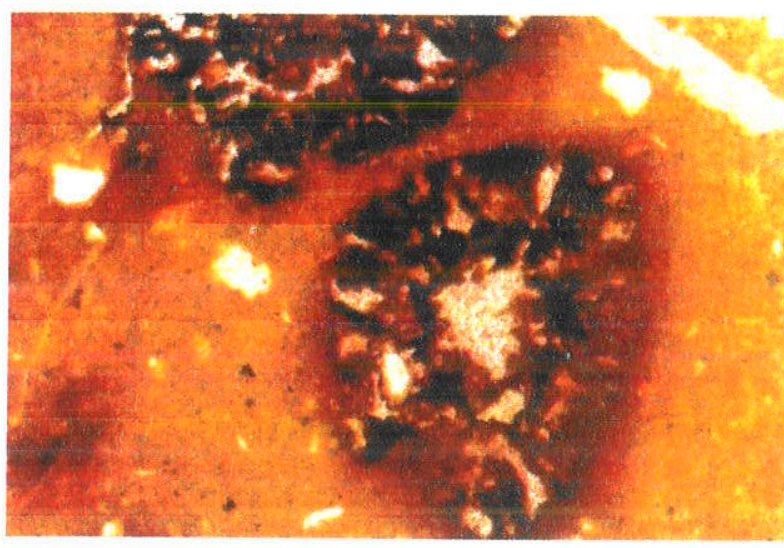

Figura V.45 - Fotomicrografia (luz natural) de cavidade preenchida por material argiloferruginoso (ferriargilan) no interior do plasma caolinítico da matriz (aresta horizontal $=1,39$ $\mathrm{mm})$.

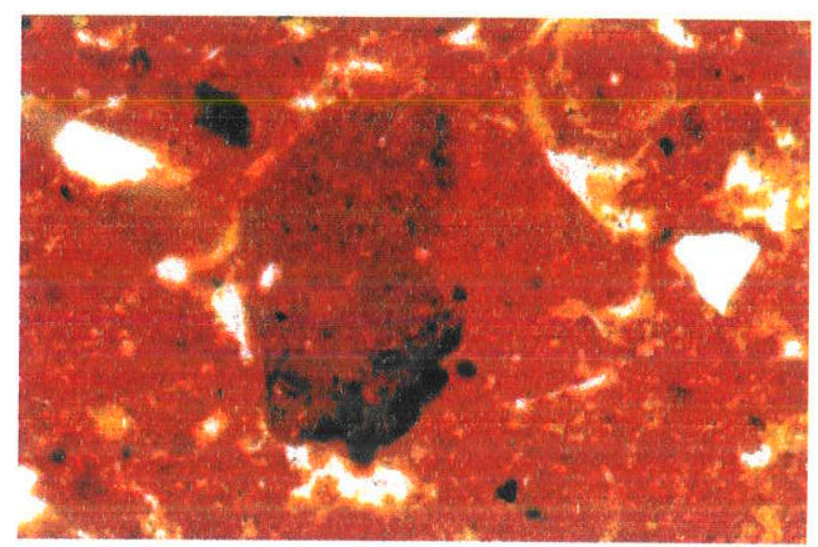

Figura V.46 - Fotomicrografia (luz natural) exibindo região de concentração de plasma goethítico e resto de couraça com grãos de quartzo inclusos (aresta horizontal $=1,39 \mathrm{~mm}$ ).

\section{Determinações em $D R X$}

As determinações em DRX foram obtidas a partir de amostras representativas da porção do afloramento de Pirapora sem "dobras" (CP) e amostras da porção com "dobras". Estas últimas, representadas pelos materiais das crostas ferruginosas (DC) e pelos materiais da matriz (DM).

Através da análise dos espectros, foi possível a identificação de quartzo, de argila do grupo da caolinita, goethita e hematita, além de biotita, ilmenita e gibbsita. Observou-se que, nas amostras da matriz há maior intensidade dos picos de caolinita, ocorrendo o mesmo com os picos de goethita nas amostras das crostas, embora estas diferenças sejam sutis. Para os outros minerais detectados, os resultados foram semelhantes. (Figuras V.47, V.48, V.49 e V.50).

Os resultados obtidos das amostras da porção do afloramento sem "dobras" (CP) não apresentaram variações significativas em relação aos resultados das amostras da porção com "dobras" (Figuras V.51).

As determinações em DRX não permitiram identificar variações na concentração dos minerais em relação a posição das amostras no perfil de coleta (topo / base). 


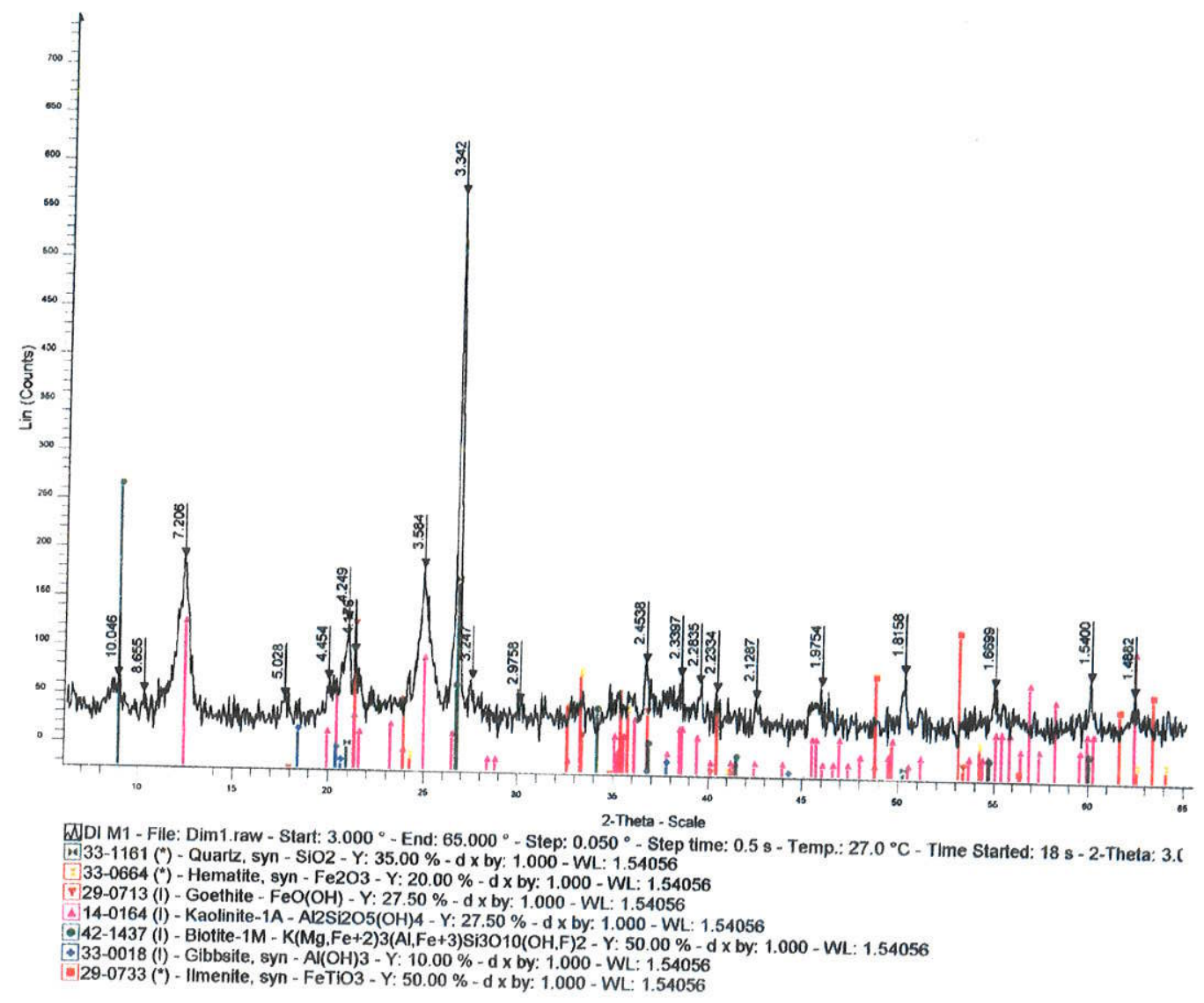

Figura V.47 - Resultado da análise por DRX para a amostra D1M1 (matriz) do afloramento de Pirapora - (Área - 3).

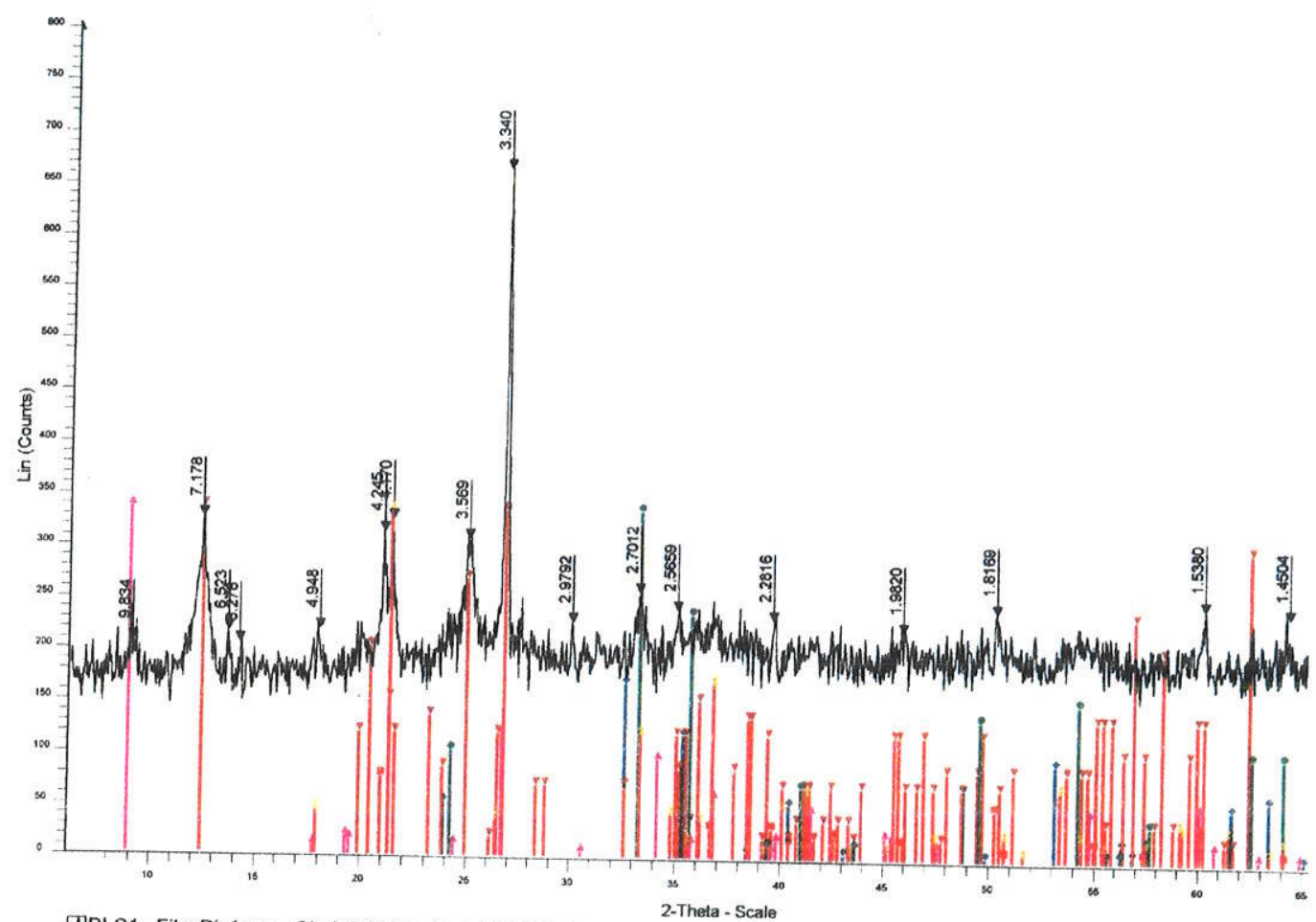
WDI C1 - File: Dic1.raw - Start: $3.000^{\circ}$ - End: $65.000^{\circ}$ - Step: $0.050^{\circ}$ - Step time: $0.5 \mathrm{~s}$ - Temp.: $27.0^{\circ} \mathrm{C}$ - Time Started: $18 \mathrm{~s}-2$-Theta: 3.01
$29-0713$ (I) - Goethite - FeO(OH) - Y: $50.00 \%-\mathrm{d}$ x by: 1.000 - WL: 1.54056 33-1161 (") - Quartz, syn - SiO2 - Y: $50.00 \%$ - d x by: 1.000 - WL: 1.54056

- $29-0733\left({ }^{*}\right)$ - limenite, syn - FeTiO3 - Y: $25.00 \%$ - d x by: 1.000 - WL: 1.54056

(14-0164 (I) - Kaolinite-1A - Al2Si2O5(OH)4 - Y: $50.00 \%$ - d x by: $1.000-$ WL: 1.54056

4 42-1437 (I) - Biotite-1M - K(Mg.Fe+2)3(Al,Fe+3)Si3O by: $1.000-W L: 1.54056$

Figura V.48 - Resultado da análise por DRX , amostra D1C1 (crosta) Pirapora (Área-3). 


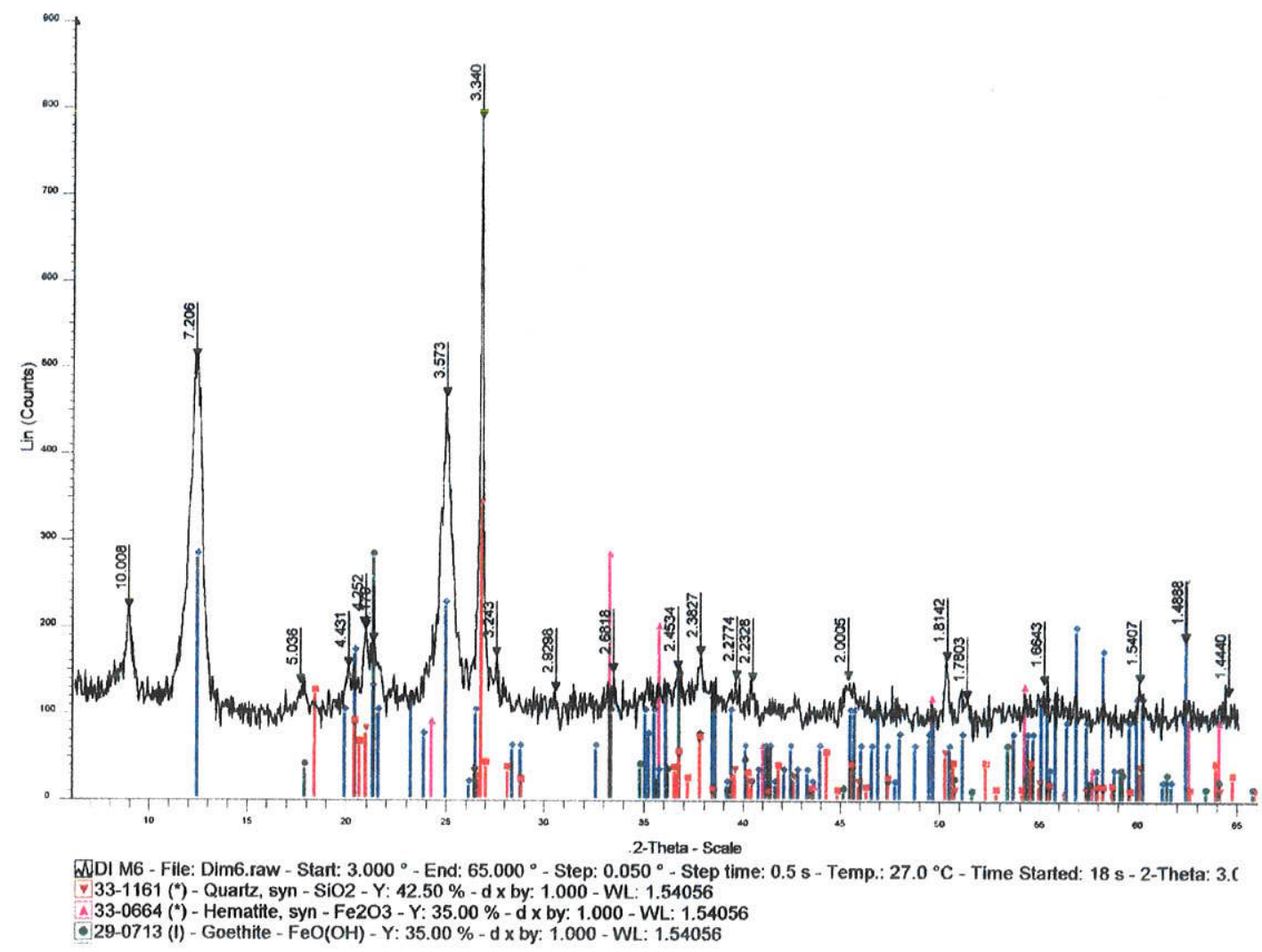

Figura V.49 - Resultado da análise por DRX para a amostra D1M6 (matriz) do afloramento de Pirapora - (Área - 3).

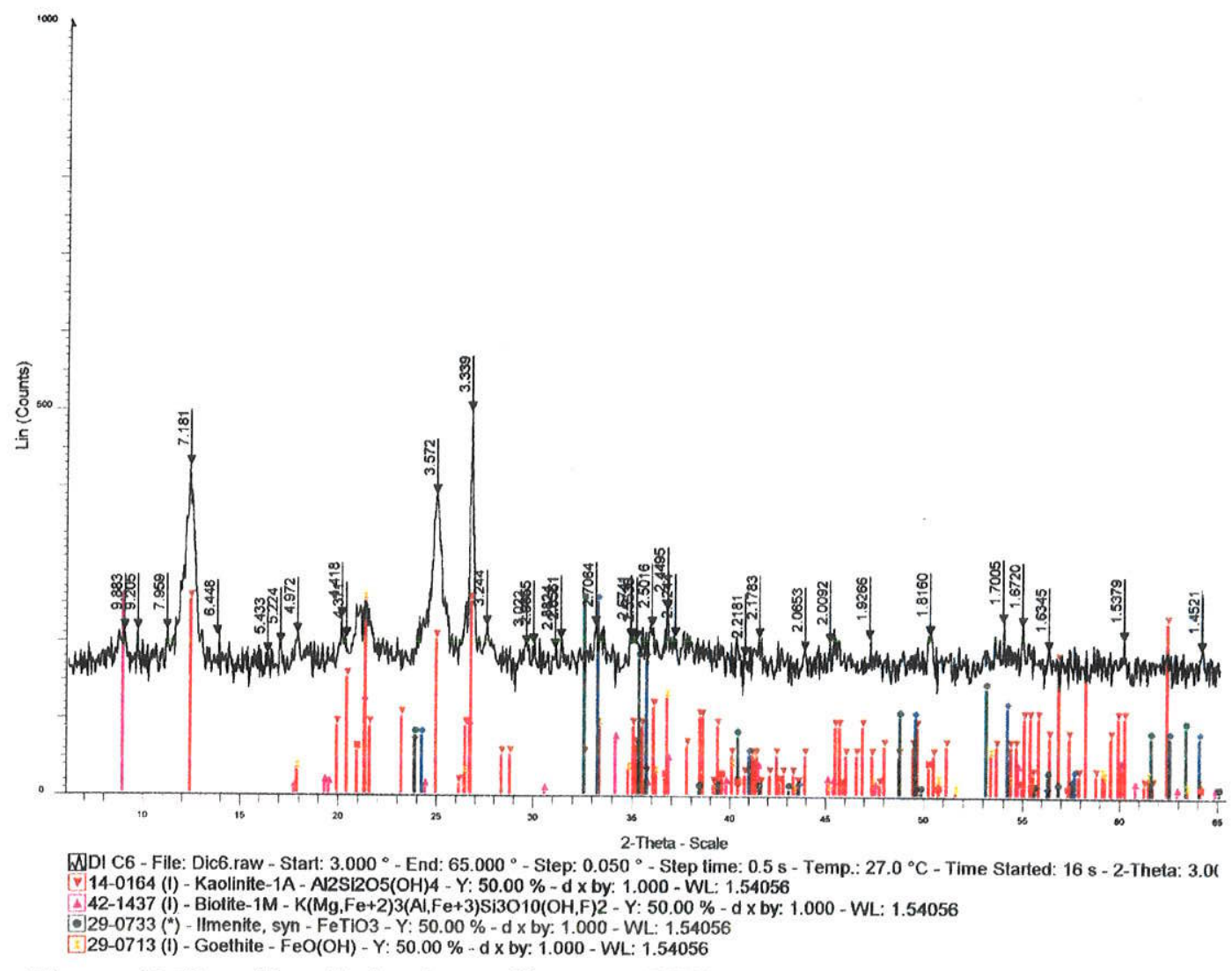

Figura V.50 - Resultado da análise por DRX para a amostra D1C6 (crosta) do afloramento de Pirapora - (Área - 3). 


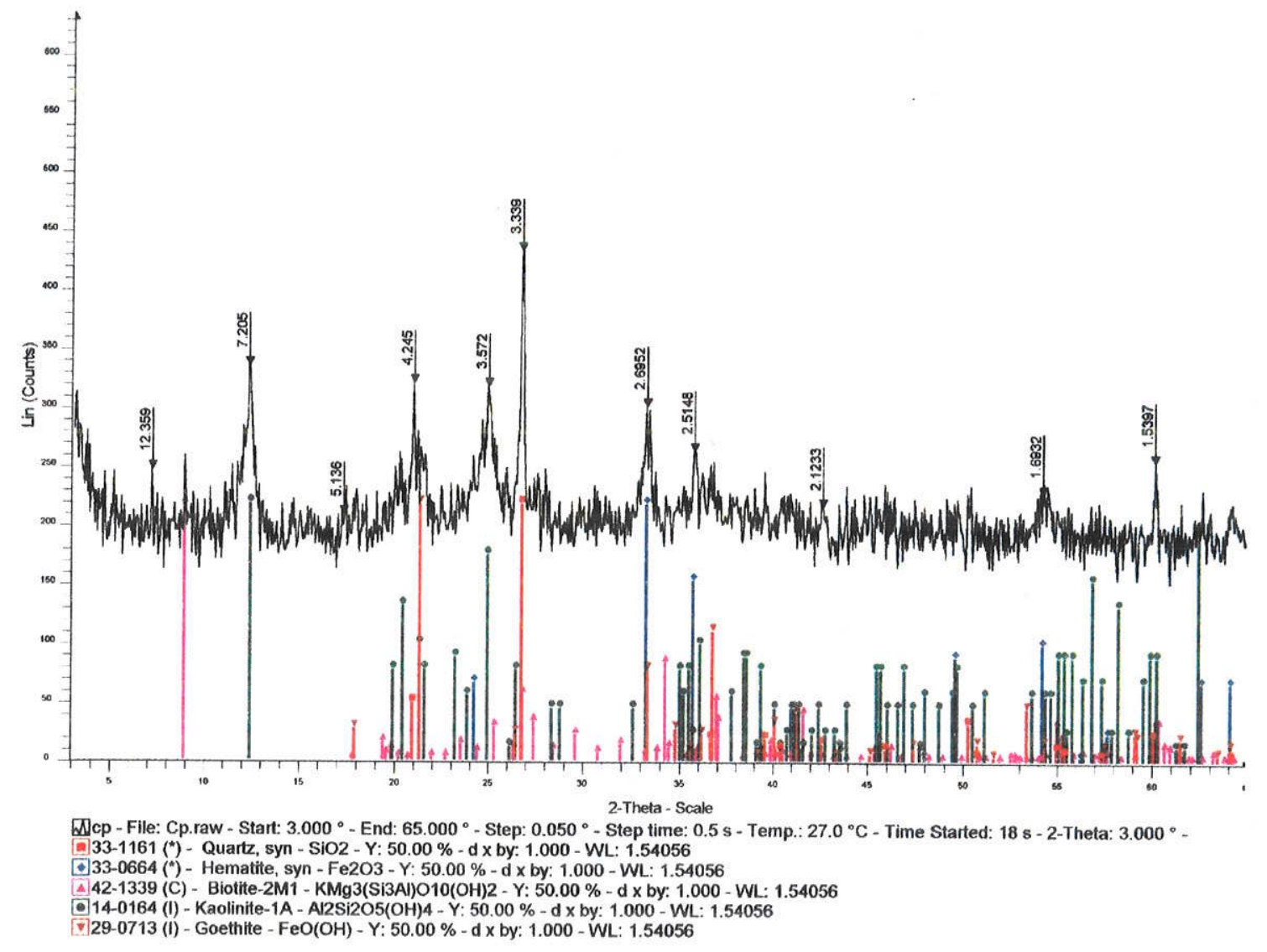

Figura V.51 - Resultado da análise por DRX para amostra CP (amostra representativa da porção do afloramento sem dobras), afloramento de Pirapora - (Área - 3).

\section{Análise de Minerais Pesados}

A análise de minerais pesados dos materiais amostrados no afloramento de Pirapora, foram aplicadas nas amostras de crosta (DC) e de matriz (DM), coletadas ao longo do perfil DI e uma amostra correspondente a porção do afloramento sem "dobras" (CP) (Figura III.4). Estas amostras foram peneiradas a 16, 35, 100 e 200 mesh e cada uma destas frações foi analisada.

Esta análise apresentou a seguinte assembléia mineralógica e estruturas associadas:

Quartzo (QTZ) - Fragmentos brancos, angulares, bastante fraturados.

Agregados foscos tabulares (AFT) - Fragmentos tabulares, castanho-amarelados, com pontos preto-acinzentados (fragmentos de rocha). 
Agregados foscos vermelhos (AFV) - Fragmentos vermelho-acastanhados, arredondados, magnéticos.

Agregados foscos ocre (AFO) - Fragmentos ocre a castanho amarelados, arredondados (goethita).

Turmalina (TUR) - Fragmentos angulares, prismáticos, de coloração âmbar a negra.

Rutilo (RUT) - Fragmentos prismáticos, de coloração rôxa a lilás.

Zircão (ZIR) - Fragmentos angulares prismáticos, incolores.

IImenita (ILM) - Fragmentos angulares negros, de brilho submetálico, tabulares, magnéticos.

Mineral fibroso (FIB) - Fragmentos angulares fibrosos, branco azulados.

Mineral cinza azulado (CNZ) - Fragmentos angulares, cinza azulados, leitosos.

Goethita (GOE) - Fragmentos arredondados ocre a castanho-amarelados e vermelhoacastanhados.

A análise mineralógica semi-quantitativa demonstrou que as amostras da matriz (DM) e as amostras da porção do afloramento sem "dobras" (CP) são mais enriquecidas em quartzo. Nas amostras das crostas (DC) predominam os agregados ferruginizados (AFV e AFO). Para as demais assembléias mineralógicas identificadas, notou-se similaridade na concentração das mesmas.

Os resultados obtidos nestas análises encontram-se nas tabelas V.5, V.6, V.7, V.8, V.9, V.10, V.11 e V.12. 


\begin{tabular}{|c|c|c|c|c|c|c|c|c|c|c|}
\hline \multicolumn{1}{|c|}{ ENSAIO : ANALISE MINERALOGICA SEMIQUANTITATIVA } & $\begin{array}{c}\text { AMOSTRA: } \\
\text { DIM1 }\end{array}$ \\
\hline FRAÇAO & PESO & \multicolumn{7}{|c|}{ ASSEMBLEIA MINERALOGICA } \\
\hline & & \multicolumn{7}{|c|}{ (\% EM PESO) } \\
\hline (mesh) & (g) & QTZ & AFV & AFO & FIB & AFT & TUR & GOE & ILM & ZIR \\
\hline$>\mathbf{1 6}$ & 1,01 & 4 & 95 & 1 & & & & & & \\
\hline$>\mathbf{3 5}$ & 3,99 & 42 & 46 & 8 & & 4 & & & & \\
\hline$>100$ & 5,92 & 83 & 12 & 5 & TR & & TR & TR & TR & \\
\hline$>200$ & 4,10 & 88 & 9 & 2 & & & TR & TR & & TR \\
\hline$<200$ & 2,91 & 91 & 6 & & & & TR & TR & & TR \\
\hline TOTAL & 17,93 & 72 & 23 & 4 & TR & 1 & TR & TR & TR & TR \\
\hline
\end{tabular}

Tabela V.5: Resultados da análise mineralógica semi-quantitativa dos minerais pesados para a amostra DIM1 (matriz), afloramento de Pirapora (Área - 3).

\begin{tabular}{|c|c|c|c|c|c|c|c|c|c|c|}
\hline \multicolumn{1}{|c|}{ ENSAIO : ANALISE MINERALOGICA SEMIQUANTITATIVA } & \multicolumn{1}{c|}{$\begin{array}{c}\text { AMOSTRA: } \\
\text { DIC1 }\end{array}$} \\
\hline FRAÇAO & PESO & \multicolumn{7}{|c|}{ ASSEMBLEIA MINERALOGICA } \\
\hline & & \multicolumn{7}{|c|}{ (\% EM PESO) } \\
\hline (mesh) & (g) & QTZ & AFT & AFV & AFO & TUR & GOE & ZIR & & \\
\hline$>\mathbf{1 6}$ & 0,09 & 20 & 20 & 30 & 30 & & & & & \\
\hline$>\mathbf{3 5}$ & 2,43 & 9 & & 91 & TR & & & & & \\
\hline$>\mathbf{1 0 0}$ & 8,25 & 2 & & 97 & 1 & TR & TR & & & \\
\hline$>\mathbf{2 0 0}$ & 5,64 & 15 & & 85 & & TR & TR & TR & & \\
\hline$<\mathbf{2 0 0}$ & 3,80 & 49 & & 50 & & TR & TR & TR & & \\
\hline TOTAL & 20,21 & 15 & TR & $\mathbf{8 4}$ & 1 & TR & TR & TR & & \\
\hline
\end{tabular}

Tabela V.6: Resultados da análise mineralógica semi-quantitativa dos minerais pesados para a amostra DIC1 (crosta), afloramento de Pirapora (Área -3).

\begin{tabular}{|c|c|c|c|c|c|c|c|c|c|c|}
\hline \multicolumn{1}{|c|}{ ENSAIO : ANÁLISE MINERALOGICA SEMIQUANTITATIVA } & $\begin{array}{c}\text { AMOSTRA: } \\
\text { DIM3 }\end{array}$ \\
\hline FAAÇAO & PESO & \multicolumn{7}{c|}{ ASSEMBLEIA MINERALOGICA } \\
\hline & & \multicolumn{7}{|c|}{ (\% EM PESO) } \\
\hline (mesh) & $\mathbf{( g )}$ & QTZ & AFV & CNZ & GOE & AFO & ANA & TUR & ZIA & \\
\hline$>\mathbf{1 6}$ & 0,10 & 100 & & & & & & & & \\
\hline$>\mathbf{3 5}$ & 0,77 & 90 & 10 & TR & TR & & & & & \\
\hline$>\mathbf{1 0 0}$ & 3,26 & 90 & 9 & TR & 1 & TR & TR & & & \\
\hline$>\mathbf{2 0 0}$ & 3,52 & 89 & 10 & & 1 & & & TR & TR & \\
\hline$<\mathbf{2 0 0}$ & 2,59 & 95 & 2 & & 1 & & & 1 & 1 & \\
\hline TOTAL & 10,24 & 91 & 8 & TA & 1 & TR & TR & TR & TR & \\
\hline
\end{tabular}

Tabela V.7: Resultados da análise mineralógica semi-quantitativa dos minerais pesados para a amostra DIM3 (matriz), afloramento de Pirapora (Área - 3). 


\begin{tabular}{|c|c|c|c|c|c|c|c|c|c|c|}
\hline \multicolumn{10}{|c|}{ ENSAO : ANALISE MINERALOGICA SEMIQUANTITATIVA } & \multicolumn{1}{c|}{$\begin{array}{c}\text { AMOSTRA: } \\
\text { DI-C3 }\end{array}$} \\
\hline FRAÇAO & PESO & \multicolumn{7}{c|}{ ASSEMBLEIA MINERALOGICA } \\
\hline & & & \multicolumn{7}{c|}{$\%$ EM PESO) } \\
\hline (mesh) & (g) & QTZ & AFO & AFV & AFT & ILM & TUR & GOE & RUT & ZIR \\
\hline$>\mathbf{1 6}$ & 0,16 & 10 & 90 & & & & & & & \\
\hline$>\mathbf{3 5}$ & 4,02 & 5 & 50 & 45 & TR & & & & & \\
\hline$>\mathbf{1 0 0}$ & 16,63 & 5 & 30 & 65 & TR & TR & TR & TR & & \\
\hline$>\mathbf{2 0 0}$ & 11,24 & 5 & 30 & 65 & & TR & TR & TR & TR & TR \\
\hline$<\mathbf{2 0 0}$ & 6,59 & 5 & 20 & 75 & & TR & TR & & TR & TR \\
\hline TOTAL & 38,64 & 5 & 31 & 64 & TR & TR & TR & TR & TR & TR \\
\hline
\end{tabular}

Tabela V.8: Resultados da análise mineralógica semi-quantitativa dos minerais pesados para a amostra DIC3 (crosta), afloramento de Pirapora (Área - 3).

\begin{tabular}{|c|c|c|c|c|c|c|c|c|c|c|}
\hline \multicolumn{7}{|c|}{ ENSAIO : ANALISE MINERALOGICA SEMIQUANTITATIVA } & $\begin{array}{c}\text { AMOSTRA: } \\
\text { OIM6 }\end{array}$ \\
\hline FRACAO & PESO & \multicolumn{7}{c|}{ ASSEMBLEIA MINERALOGICA } \\
\hline & & \multicolumn{7}{|c|}{ (\% EM PESO) } \\
\hline (mesh) & (g) & QTZ & CNZ & TUR & GOE & ZIR & & & & \\
\hline$>16$ & & & & & & & & & & \\
\hline$>35$ & 0,33 & 100 & & & & & & & & \\
\hline$>100$ & 2,80 & 99 & 1 & TR & TR & & & & & \\
\hline$>200$ & 3,13 & 98 & TR & 1 & 1 & TR & & & & \\
\hline$<200$ & 2,46 & 96 & TR & 1 & 2 & 1 & & & & \\
\hline TOTAL & 8,72 & 98 & TR & 1 & 1 & TR & & & & \\
\hline
\end{tabular}

Tabela V.9: Resultados da análise mineralógica semi-quantitativa dos minerais pesados para a amostra DIM6 (matriz), afloramento de Pirapora (Área - 3).

\begin{tabular}{|c|c|c|c|c|c|c|c|c|c|c|c|c|}
\hline \multicolumn{9}{|c|}{ ENSAIO : ANÁLISE MINERALOGICA SEMIQUANTITATIVA } & \multicolumn{4}{|c|}{ AMOSTRA: DI-C6 } \\
\hline FRACAO & PESO & \multicolumn{11}{|c|}{ ASSEMBLEIA MINERALÓGICA } \\
\hline & & \multicolumn{11}{|c|}{ (\% EM PESO) } \\
\hline (mesh) & (g) & QTZ & TUR & FIB & AFT & AFV & AFO & CNZ & RUT & $\mathrm{ZIA}$ & GOE & ILM \\
\hline$>16$ & 0,01 & 100 & & & & & & & & & & \\
\hline$>35$ & 0,67 & 91 & 9 & TR & TR & & & TA & & & & \\
\hline$>100$ & 5,06 & 44 & TR & TR & & 30 & 26 & & & TR & TR & \\
\hline$>200$ & 6,25 & 40 & TR & & & 35 & 25 & & TR & TR & TR & $\overline{T R}$ \\
\hline$<200$ & 4,68 & 40 & TR & & & 39 & 20 & & TA & TR & $\mathrm{TR}$ & TR \\
\hline TOTAL & 16,67 & 43 & TR & TR & TR & 34 & 23 & $\mathrm{TA}$ & TR & TR & TR & TR \\
\hline
\end{tabular}

Tabela V.10: Resultados da análise mineralógica semi-quantitativa dos minerais pesados para a amostra DIC6 (crosta), afloramento de Pirapora (Área - 3). 


\begin{tabular}{|c|c|c|c|c|c|c|c|c|c|c|}
\hline \multicolumn{10}{|c|}{ ENSAIO : ANALISE MINERALOGICA SEMIQUANTITATIVA } & $\begin{array}{c}\text { AMOSTRA: } \\
\text { DI-C7 }\end{array}$ \\
\hline FRAÇAO & PESO & \multicolumn{7}{|c|}{ ASSEMBLEIA MINERALOGICA } \\
\hline & & & \multicolumn{7}{c|}{ (\% EM PESO) } \\
\hline (mesh) & (g) & QTZ & AFT & AFO & TUR & AFV & ILM & ZIR & & \\
\hline$>16$ & 0,03 & & 100 & & & & & & & \\
\hline$>35$ & 4,47 & 1 & 99 & TR & TR & & & & & \\
\hline$>100$ & 11,89 & 10 & 55 & 20 & TR & 15 & TR & & & \\
\hline$>200$ & 7,68 & 40 & 2 & 25 & TR & 32 & TR & TR & & \\
\hline$<200$ & 5,33 & 30 & 3 & 25 & TR & 42 & TR & TR & & \\
\hline TOTAL & 29,40 & 20 & 39 & 19 & TR & 22 & TR & TR & & \\
\hline
\end{tabular}

Tabela V.11: Resultados da análise mineralógica semi-quantitativa dos minerais pesados para a amostra DIC7 (crosta), afloramento de Pirapora (Área - 3).

\begin{tabular}{|c|c|c|c|c|c|c|c|c|c|c|c|}
\hline \multicolumn{10}{|c|}{ ENSAO : ANÁLISE MINERALOGICA SEMIQUANTITATIVA } & \multicolumn{1}{c|}{ AMOSTRA: CP } \\
\hline FAACAO & PESO & \multicolumn{10}{|c|}{ ASSEMBLEIA MINERALOGICA } \\
\hline & & \multicolumn{10}{|c|}{$\%$ EM PESO) } \\
\hline (mesh) & (g) & QTZ & AFT & AFV & AFO & GOE & PSE & TUR & MAG & RUT & ZIR \\
\hline$>\mathbf{1 6}$ & 0,01 & 100 & & & & & & & & & \\
\hline$>\mathbf{3 5}$ & 1,47 & 75 & 14 & 11 & TR & TR & TR & & & & \\
\hline$>\mathbf{1 0 0}$ & 5,36 & 60 & 10 & 30 & TR & TR & TR & TR & & & \\
\hline$>\mathbf{2 0 0}$ & 5,02 & 40 & TR & 36 & 24 & TR & TR & TR & TR & TR & TR \\
\hline$<\mathbf{2 0 0}$ & 3,54 & 40 & TR & $\mathbf{4 1}$ & 19 & TR & TR & TR & TR & TA & TR \\
\hline TOTAL & 15,40 & 50 & 5 & $\mathbf{3 3}$ & 12 & TR & TR & TR & TR & TR & TR \\
\hline
\end{tabular}

Tabela V.12: Resultados da análise mineralógica semi-quantitativa dos minerais pesados para a amostra da porção sem "dobras" do afloramento de Pirapora (Área - 3). 


\section{Comportamento Químico dos Elementos}

\section{Análises Químicas Totais}

O comportamento químico dos elementos $\mathrm{Si}, \mathrm{Al}$ e $\mathrm{Fe}$ ao longo dos perfis de amostragem, localizados na porção com "dobras" do afloramento de Pirapora (Perfis D1, D2 e D3 - Figura V.52), indica concentração mais elevada de ferro nas amostras correspondentes às crostas (amostras PDC) e de sílica e alumínio nas amostras correspondentes a matriz (amostras PDM). O ferro ocorre em concentrações mais elevadas nas crostas localizadas no topo dos perfis. Nos perfis localizados na porção sem "dobras" do afloramento (Perfis ST e CP - Figura V.52), observou-se que o ferro se concentra na região da couraça ferruginosa, localizada na parte superior do afloramento e o alumínio e o silício ocorrem em porcentagens praticamente constante ao longo destes perfis (Figura V.52).

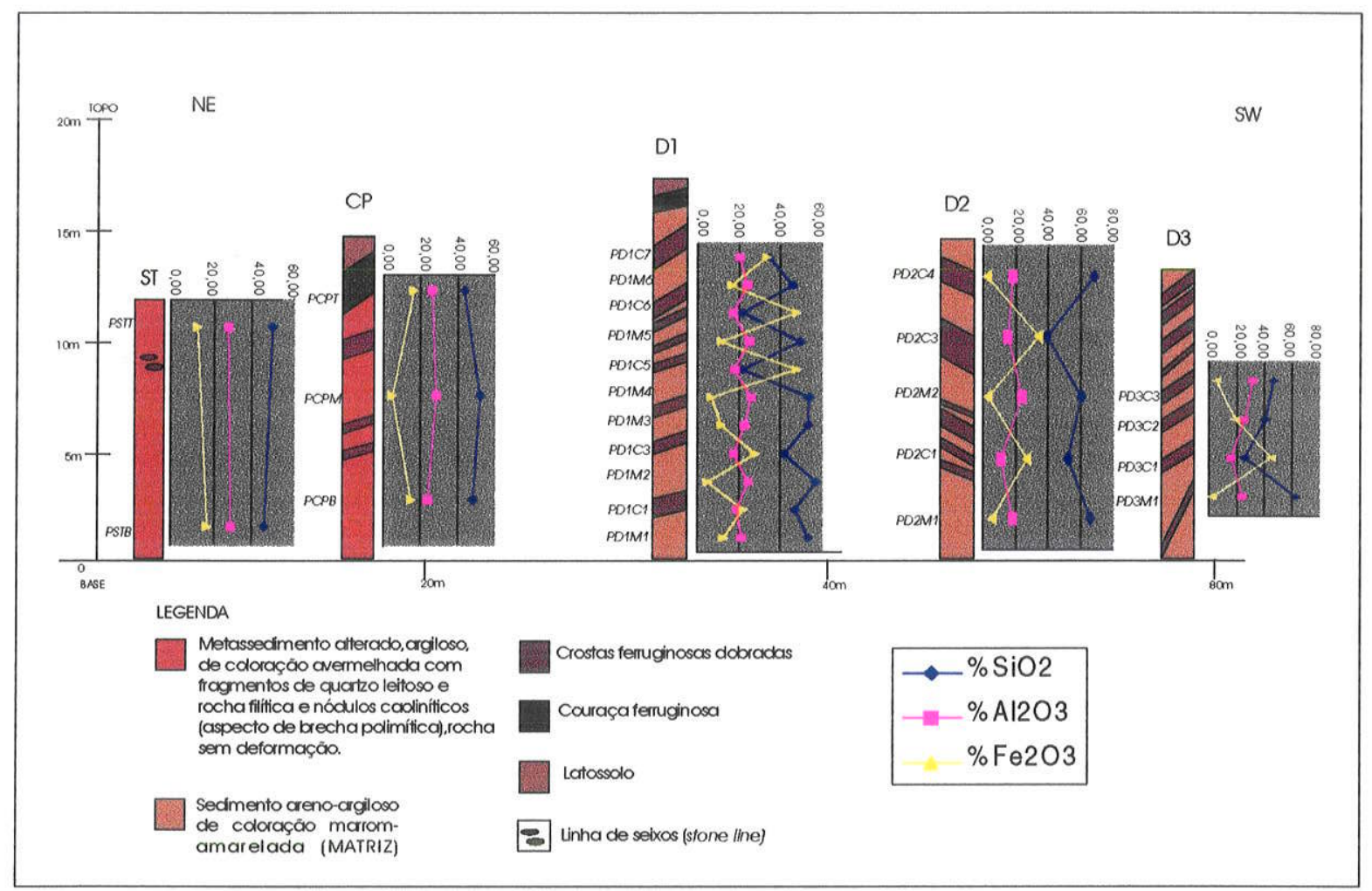

Figura V.52 - Comportamento geoquímico dos elementos $\mathrm{Si}, \mathrm{Al}$ e $\mathrm{Fe}$ ao longo dos perfis estudados (afloramento de Pirapora - Área 3). 
Os diagramas geoquímicos discriminativos exibem três campos de agrupamento das amostras, um das amostras das crostas, um das amostras da matriz e outro das amostras correspondentes a porção sem "dobras" do afloramento.

Em relação aos elementos $\mathrm{Si}, \mathrm{Al}$ e $\mathrm{Fe}$, observou-se nestes diagramas que as amostras das crostas são mais enriquecidas em ferro e as amostras da matriz mais em alumínio e silício. Nas amostras da porção sem "dobras" do afloramento estes elementos ocorrem em porcentagens intermediárias, tendendo a concentrações mais próximas das observadas nas amostras da matriz da porção com "dobras" do afloramento (Figuras V.53 diagrama $\mathrm{Fe}_{2} \mathrm{O}_{3} \times \mathrm{Al}_{2} \mathrm{O}_{3} \times \mathrm{SiO}_{2}$, V.54 diagrama $\mathrm{Fe}_{2} \mathrm{O}_{3} \times \mathrm{SiO}_{2}$, V.55 diagrama $\mathrm{Al}_{2} \mathrm{O}_{3} \times \mathrm{SiO}_{2}$ e V.56 diagrama $\left.\left(\mathrm{Al}_{2} \mathrm{O}_{3}+\mathrm{Fe}_{2} \mathrm{O}_{3}\right) \times \mathrm{SiO}_{2}\right)$.

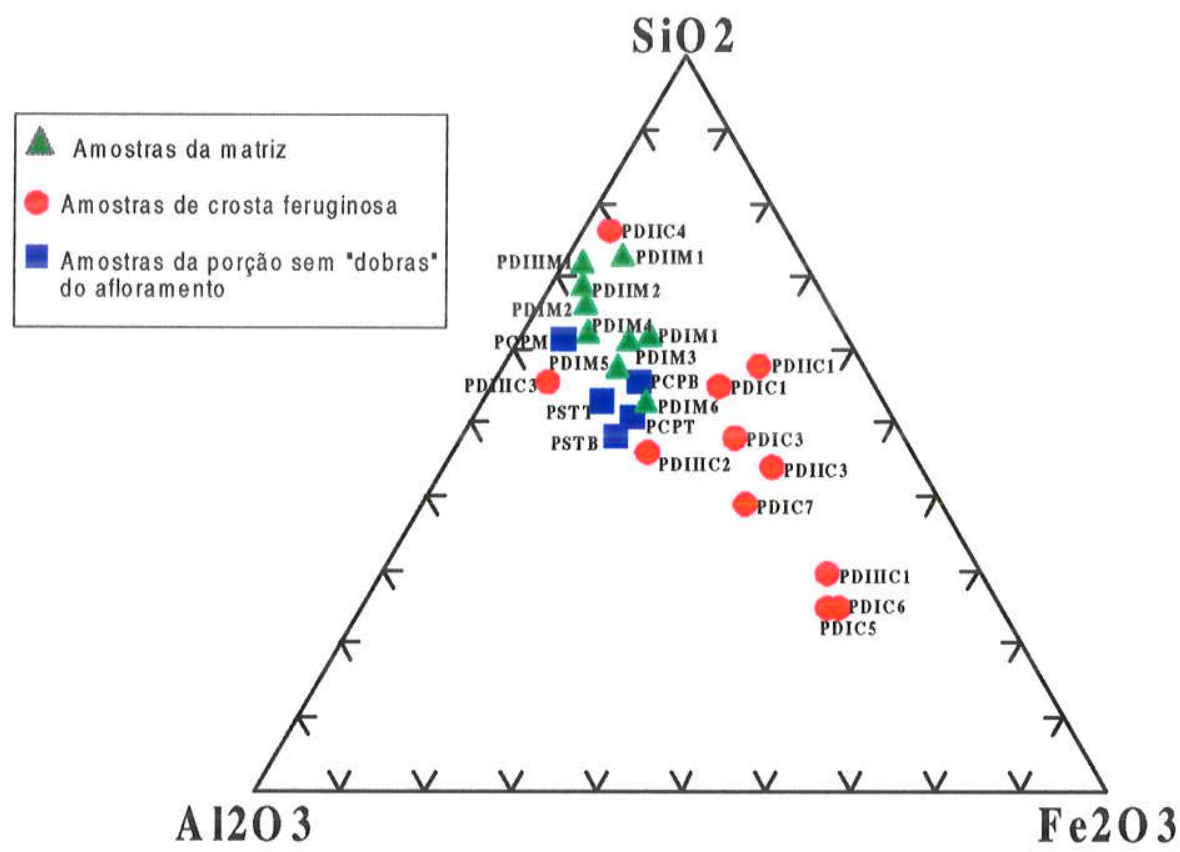

Figura V.53 - Diagrama geoquímico discriminativo $\mathrm{Fe}_{2} \mathrm{O}_{3} \times \mathrm{Al}_{2} \mathrm{O}_{3} \times \mathrm{SiO}_{2}$ (\%), exibindo a distribuição dos campos de agrupamento das amostras em função do comportamento geoquímico dos elementos $\mathrm{Si}, \mathrm{Al}$ e $\mathrm{Fe}$. Observa-se concentração mais elevada de ferro nas amostras das crostas (em vermelho) e de silício e alumínio nas amostras da matriz (em verde) e nas amostras da porção sem "dobras" do afloramento (em azul) (Pirapora - Área 3). 


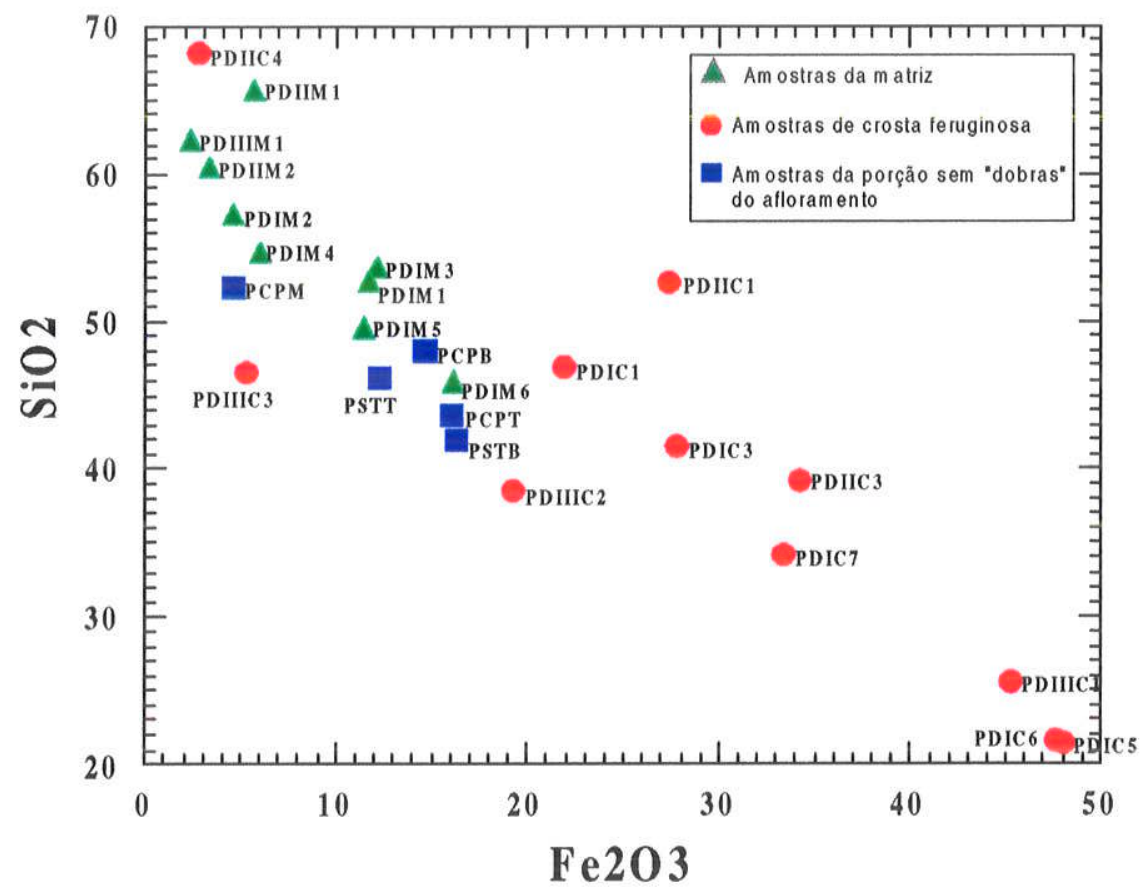

Figura V.54 - Diagrama geoquímico discriminativo $\mathrm{Fe}_{2} \mathrm{O}_{3} \times \mathrm{SiO}_{2}$ (\%), exibindo a distribuição dos campos de agrupamento das amostras em função do comportamento geoquímico dos elementos $\mathrm{Si}$ e Fe. Observa-se concentração mais elevada de ferro nas amostras das crostas (em vermelho) e de silício nas amostras da matriz (em verde) As amostras da porção sem "dobras" do afloramento (em azul) localizam-se num campo intermediário neste diagrama (Pirapora - Área 3).

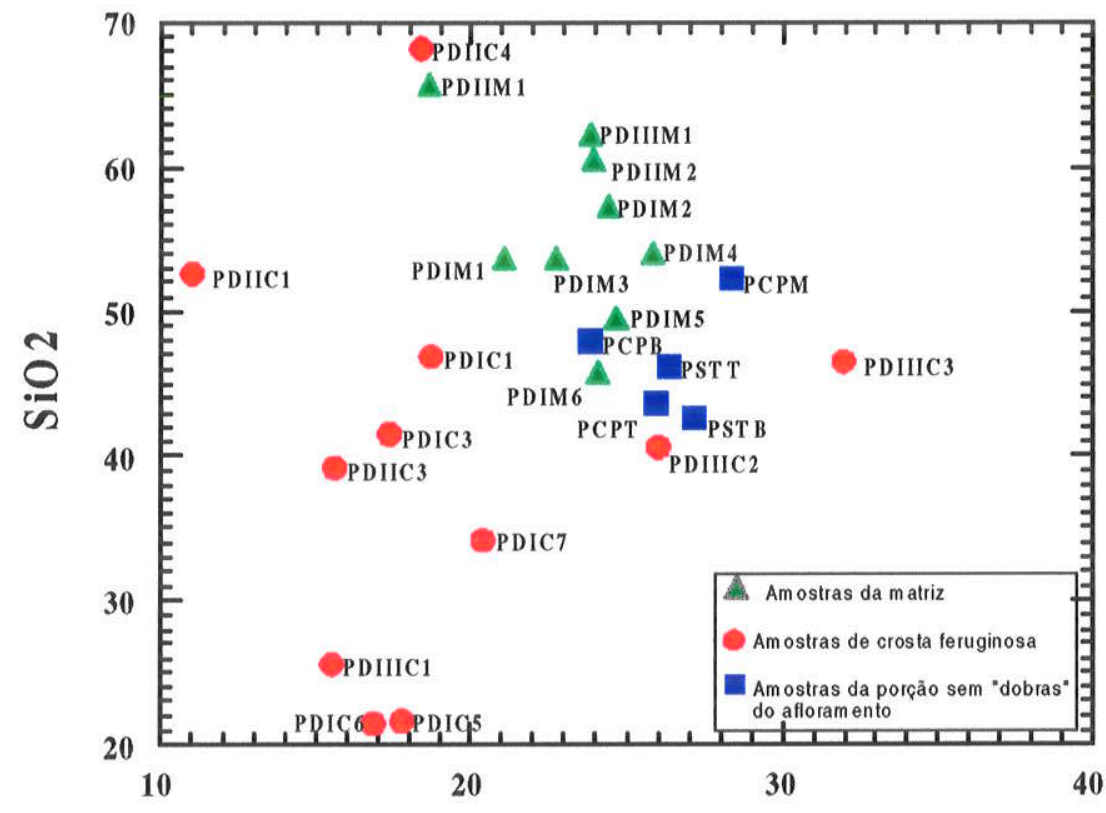

\section{A 1203}

Figura V.55 - Diagrama geoquímico discriminativo $\mathrm{Al}_{2} \mathrm{O}_{3} \times \mathrm{SiO}_{2}(\%)$, exibindo a distribuição dos campos de agrupamento das amostras em função do comportamento geoquímico dos elementos Si e Al. Observa-se concentração mais elevada de alumínio nas amostras da matriz (em verde) e nas amostras da porção sem "dobras" do afloramento (Pirapora - Área 3). 


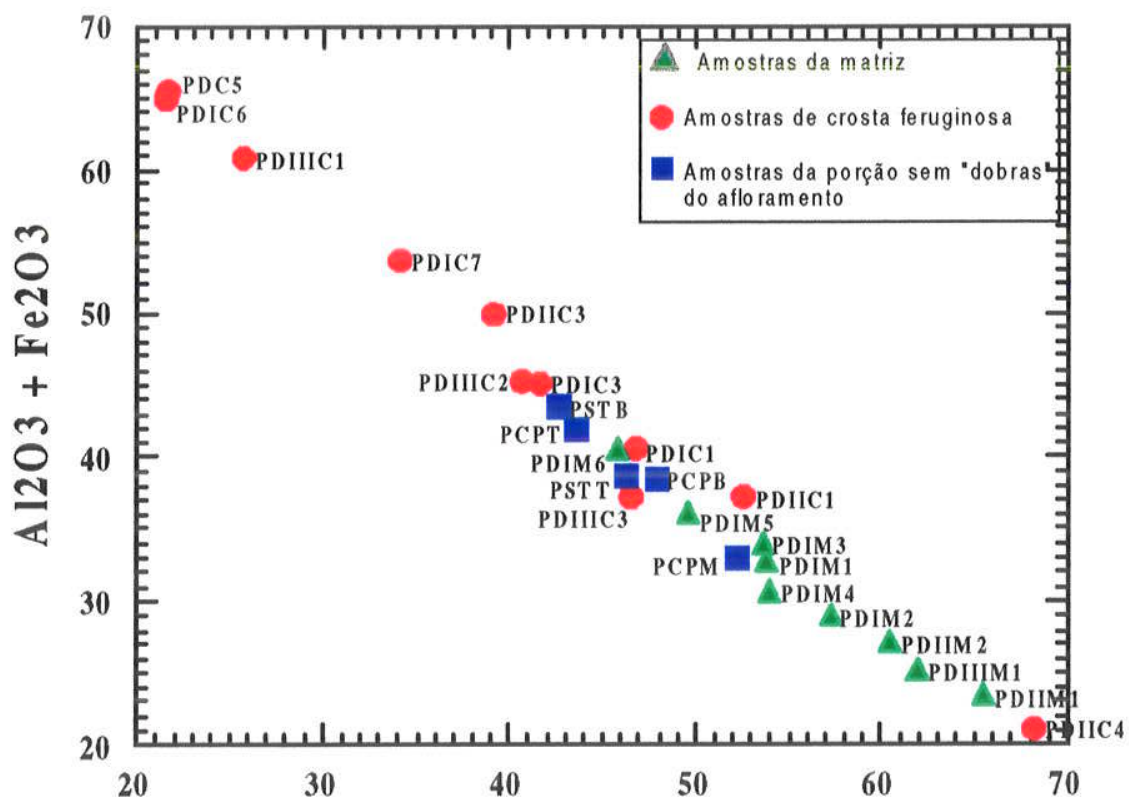

$\mathrm{SiO} 2$

Figura V.56 - Diagrama geoquímico discriminativo $\left(\mathrm{Al}_{2} \mathrm{O}_{3}+\mathrm{Fe}_{2} \mathrm{O}_{3}\right) \times \mathrm{SiO}_{2}(\%)$, exibindo a distribuição dos campos de agrupamento das amostras em função do comportamento geoquímico dos elementos $\mathrm{Si}, \mathrm{Al}$ e Fe (Pirapora - Área 3).

Quanto ao comportamento químico dos elementos alcalinos ( $\mathrm{Mg}, \mathrm{Ca}$, $\mathrm{Na}$ e K), observou-se a eliminação dos mesmos nas amostras das crostas e relativa concentração destes nas amostras da matriz, principalmente nas amostras correspondentes a porção sem "dobras" do afloramento, embora em porcentagens reduzidas, na ordem de ppm (Figura V.57 diagrama $\mathrm{SiO}_{2} \times$ Alcalinos).

O titânio aparece em concentrações mais elevadas nas amostras correspondentes a porção sem "dobras" do afloramento e nas amostras da matriz. Nas amostras das crostas foram observadas as menores concentrações de titânio (Figura V.58 diagrama $\left.\mathrm{SiO}_{2} \times \mathrm{TiO}_{2}\right)$.

Foi observado também nos diagramas geoquímicos a ocorrência do níquel como elemento traço em concentrações mais elevadas nas amostras correspondentes a porção sem "dobras" do afloramento, principalmente nas amostras coletadas na base dos perfis. Nas amostras das crostas e da matriz o níquel ocorre em porcentagens relativamente equivalentes (Figura V.59 diagrama $\mathrm{SiO}_{2}(\%)$ x Ni (ppm)). 


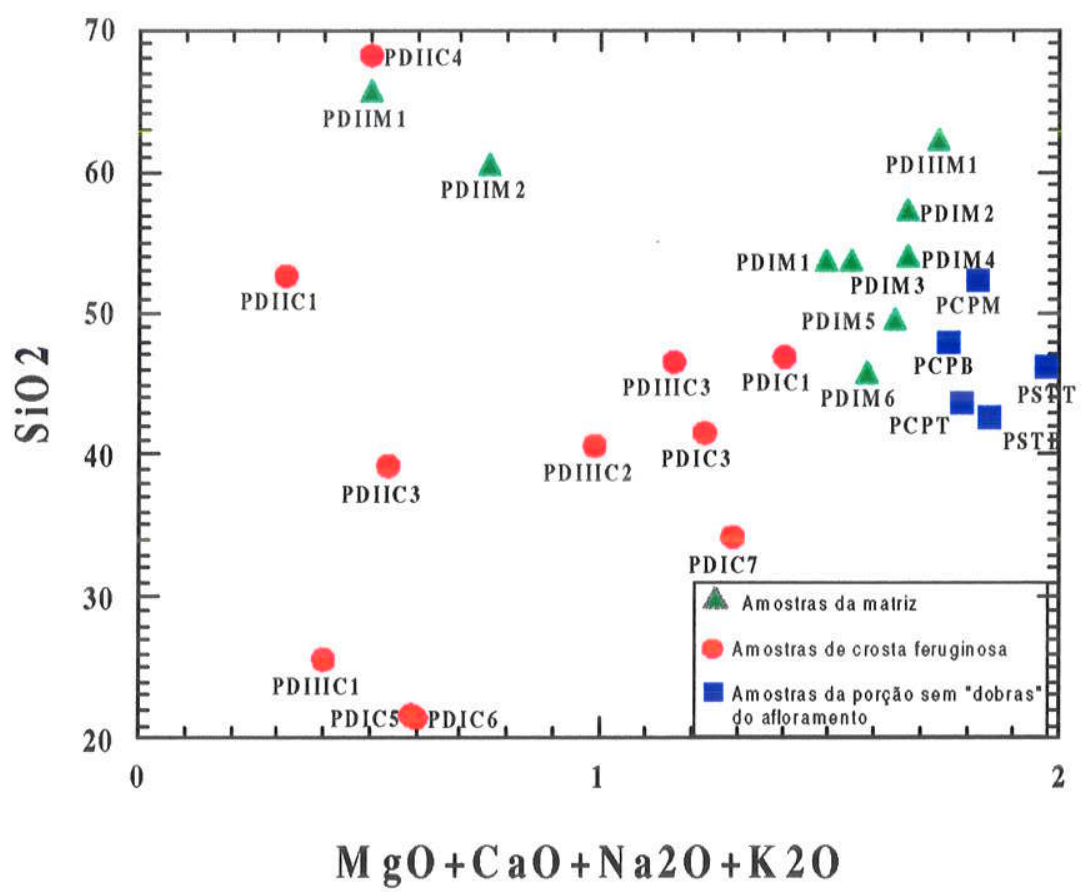

Figura V.57 - Diagrama geoquímico discriminativo $\mathrm{SiO}_{2} \times\left(\mathrm{MgO}_{2}+\mathrm{CaO}+\mathrm{Na}_{2} \mathrm{O}+\mathrm{K}_{2} \mathrm{O}\right)$ (\%), exibindo a distribuição dos campos de agrupamento das amostras em função do comportamento geoquímico dos elementos Si e alcalinos. Observa-se concentração mais elevada dos elementos alcalinos nas amostras da porção sem "dobras" do afloramento (em azul) e nas amostras da matriz (em verde), além da eliminação dos mesmos nas amostras das crostas (em vermelho) (Pirapora - Área 3).

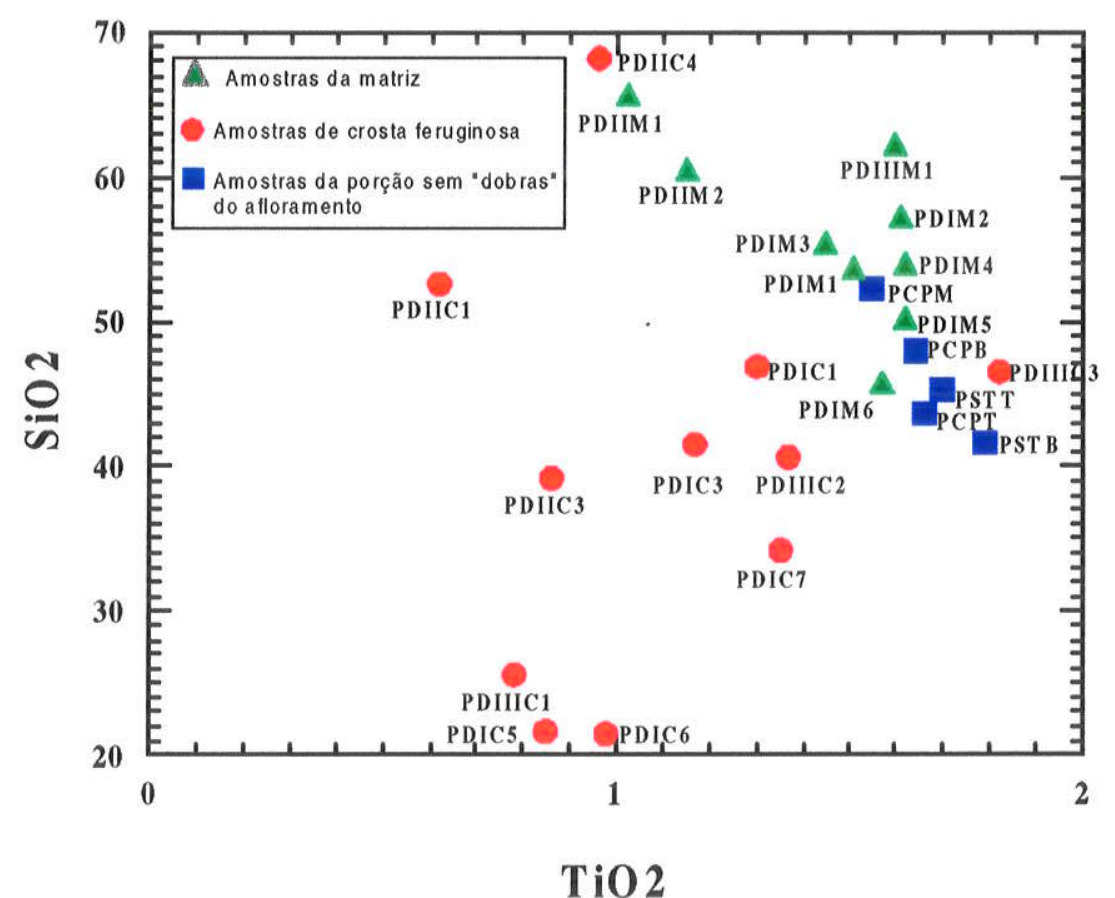

Figura V.58 - Diagrama geoquímico discriminativo $\mathrm{SiO}_{2} \times \mathrm{TiO}_{2}$ (\%), exibindo a distribuição dos campos de agrupamento das amostras em função do comportamento geoquímico dos elementos $\mathrm{Si}$ e Ti. Observa-se a concentração mais elevada de Ti nas amostras da porção sem "dobras" do afloramento (em azul) e nas amostras da matriz (em verde) (Pirapora - Área 3). 


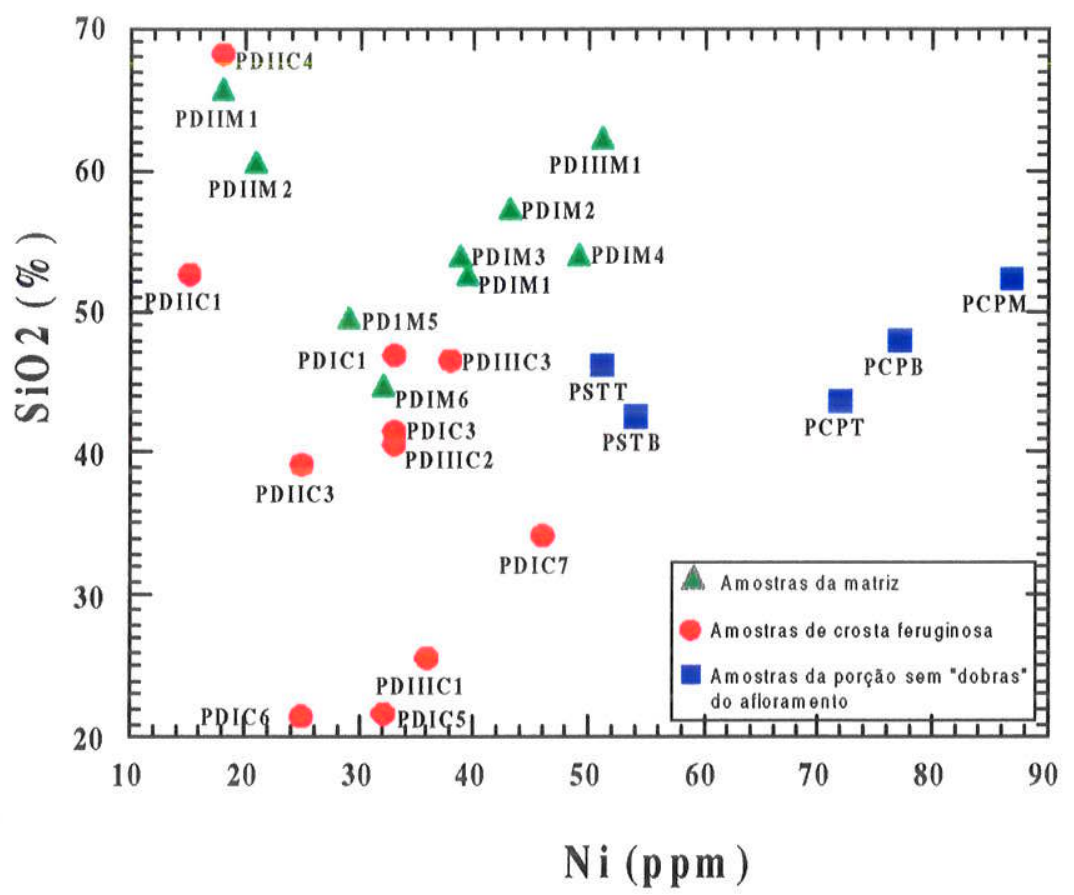

Figura V.59 - Diagrama geoquímico discriminativo $\mathrm{SiO}_{2}(\%) \times \mathrm{Ni}(\mathrm{ppm})$, exibindo a distribuição dos campos de agrupamento das amostras em função do comportamento geoquímico dos elementos $\mathrm{Si}$ e $\mathrm{Ni}$. Observa-se concentração mais elevada de Ni nas amostras correspondentes a porção sem "dobras" do afloramento (em azul) (Pirapora - Área 3).

Não foi possível identificar, nestes diagramas, a formação de trends de evolução geoquímica exibindo enriquecimento ou empobrecimento progressivo em algum determinado elemento químico, em relação a posição das amostras nos perfis analisados.

Os resultados obtidos nas análises químicas totais para as amostras do afloramento de Pirapora encontram-se na tabela V.13. 


\begin{tabular}{|c|c|c|c|c|c|c|c|c|c|c|c|c|c|c|c|c|c|c|c|}
\hline AMOSTRA & $\% \mathrm{StO}_{2}$ & $\% \mathrm{Al}_{2} \mathrm{O}_{3}$ & $\% \mathrm{Fe}_{2} \mathrm{O}_{3}$ & $\% \mathrm{MgO}$ & $\% \mathrm{CaO}$ & $\% \mathrm{Na}_{2} \mathrm{O}$ & $\% \mathrm{~K}_{2} \mathrm{O}$ & $\% \mathrm{P}_{2} \mathrm{O}_{5}$ & YMAnO & $\% \mathrm{TO}_{2}$ & \%P.F. & \% Total & $\% \mathrm{H}_{2}$ & $\mathrm{Ba}$ (ppm) & $\mathrm{Cr}$ (ppm) & $N i(p p m)$ & Sr (ppm) & $V(\mathrm{ppm})$ & $\mathrm{Zr}(\mathrm{ppm})$ \\
\hline PSTT & 46,23 & 26.35 & 12.25 & 0.38 & 0,04 & 0.13 & 1.42 & 0.03 & 0,02 & 1,71 & 10.92 & 99.47 & $2,3 B$ & 317 & 133 & 51 & 54 & 286 & 380 \\
\hline PSTB & 42,65 & 27.19 & 16.34 & 0.24 & 0,03 & 0,17 & 1.41 & 0.04 & 0,03 & 1.75 & 10,51 & 100,36 & 1.85 & 306 & 184 & 54 & 70 & 271 & 346 \\
\hline PCPT & 43,64 & 25.96 & 16.00 & 0.21 & 0,02 & 0,19 & 1,37 & 0.04 & 0,04 & 1.66 & 10,16 & 99,30 & 1,94 & 278 & 208 & 72 & 70 & 270 & 321 \\
\hline PCPB & 47,94 & 23,81 & 14,69 & 0,20 & 0.02 & 0,19 & 1,35 & 0,03 & 0,03 & 8,64 & 9,31 & 99,22 & 1.89 & 277 & 223 & 77 & 69 & 246 & 316 \\
\hline PCPM & 52,26 & 28,34 & 4.57 & 0.25 & 0.02 & 0.16 & 1,39 & 0,02 & 0,01 & 1,55 & 10,51 & 89,07 & 2,03 & 287 & $\uparrow 21$ & 87 & 63 & 118 & 320 \\
\hline PDtM1 & 53.62 & 21,06 & 12.14 & 0.19 & 0.04 & 0.14 & 1.12 & 0,05 & 0,01 & 1,45 & 9,23 & 99,05 & 1,39 & 239 & 176 & 40 & 63 & 219 & 305 \\
\hline PDtCt & 46.87 & 18,72 & 21,94 & 0.17 & 0,03 & 0,18 & 1,02 & 0.08 & 0,04 & 1,30 & 8,55 & 98,89 & 4.56 & 2.12 & 126 & 33 & 57 & 217 & 265 \\
\hline PO1M2 & 57,36 & 24,37 & 4,64 & 0,21 & 0.02 & 0,15 & 1,29 & 0,03 & 0,01 & 1,61 & 9,11 & 98,82 & 1,99 & 276 & 144 & 43 & 73 & 242 & 342 \\
\hline PO1C3 & 41,58 & $\$ 7,40$ & 27,75 & 0,15 & 0.02 & 0.12 & 0.94 & 0,12 & 0,0 t & 1,17 & 9,20 & 98.47 & 1,73 & 199 & 290 & 33 & 51 & 354 & 231 \\
\hline PD1M3 & 53,68 & 22.72 & 11,23 & 0.20 & 0.02 & 0.14 & 1,49 & 0.03 & 0,01 & 1,51 & 9,24 & 99,97 & 2,10 & 254 & 147 & 40 & 64. & 197 & 311 \\
\hline PD1M4 & 54.08 & 25.85 & 6.66 & 0,21 & 0,02 & 0.16 & 1,28 & 0,04 & 0,01 & 1,62 & 10,07 & 99,99 & 2,02 & 276 & 189 & 49 & 72 & 243 & 334 \\
\hline PD1C5 & 21,69 & 17.80 & 47,69 & 0.09 & 0.06 & 0.04 & 0.40 & 0.06 & 0,01 & 0,85 & 9.61 & 98,31 & 7,69 & 105 & 184 & 32 & 37 & 283 & 264 \\
\hline PD1M5 & 49,58 & 24,69 & 11.44 & 0.20 & 0,03 & 0.16 & 1,25 & 0.03 & 0.01 & 1.63 & 9,89 & 98,91 & $\{.71$ & 264 & $i 62$ & 29 & 68 & 232 & 329 \\
\hline PDIC6 & 21.47 & 16,89 & 48,01 & 0,08 & 0.03 & 0,03 & 0,46 & 0,04 & 0,02 & 0,98 & 10,17 & 98,18 & 1.66 & 126 & 48 & 25 & 63 & 128 & 281 \\
\hline PDIME & 45,86 & 24.07 & 16.59 & 0,19 & 0.06 & 0.16 & 1.17 & 0.04 & 0,01 & 1,57 & 10,37 & 100,08 & 1.76 & 239 & 202 & 32 & 65 & 325 & 322 \\
\hline PDIC? & 34,09 & 20,39 & 33.35 & 0.15 & 0,03 & 0,13 & 0,98 & 0,03 & 0.02 & 1,35 & 10.08 & 100,60 & 1.43 & 205 & 154 & 46 & 55 & 219 & 279 \\
\hline PDIMI & 65.66 & 18.64 & 5,73 & 0,08 & 0.01 & 0,03 & 0,38 & 0.03 & 0.02 & 1,02 & 8,97 & 100,57 & 7,80 & 98 & 39 & 18 & 35 & 73 & 820 \\
\hline PDIIC1 & 52.57 & 10,95 & 27,36 & 0.04 & 0.01 & 0,03 & 0,24 & 0,03 & 0,01 & 0,62 & 9.01 & 100,86 & 1,91 & 51 & 90 & $<15$ & 16 & 129 & 585 \\
\hline PDIIN2 & 60.52 & 23,88 & 3.36 & 0,71 & 0,01 & 0.04 & 0,60 & 0.04 & 0.01 & 1,35 & 9,93 & 99.65 & 1.71 & 164 & 58 & 21 & 67 & 102 & 844 \\
\hline PDilC3 & 39,14 & 15.64 & 34.26 & 0,07 & 0,02 & 0.03 & 0.42 & 0,04 & 0,01 & 0.86 & 9,28 & 99,77 & 1,61 & 107 & 87 & 25 & 36 & 119 & 803 \\
\hline PDIIC4 & 68,26 & 18,36 & 2,72 & 0.08 & 0,01 & 0.03 & 0,38 & 0,04 & 0,02 & 0,96 & 9,66 & 100,52 & 2.08 & 101 & 43 & 18 & 36 & 63. & 768 \\
\hline PDIIIM1 & 62,29 & 23,80 & 2,33 & 0.19 & 0,03 & 0,18 & 1,34 & 0,02 & 0,01 & 1,60 & 8,09 & 99,89 & 2,00 & 280 & 169 & 51 & 83 & 199 & 329 \\
\hline PDIICt & 25,66 & 15,56 & 45.22 & 0,09 & 0,03 & 0,04 & 0,24 & 0,06 & 0.01 & 0,78 & 11,70 & 99,40 & 1,71 & 105 & 99 & 36 & 35 & 190 & 254 \\
\hline PDIIC2 & 40,67 & 26,01 & 19,24 & 0.15 & 0,03 & 0,05 & 0,76 & 0,11 & 0,01 & 1,37 & 11,50 & 99,90 & 1.77 & 181 & 140 & 33 & 69 & 365 & 298 \\
\hline PDiltC3 & 46,51 & 31,93 & 5,33 & 0,17 & 0,01 & 0,05 & 0.93 & 0,06 & 0.01 & 1,82 & 12,68 & 99,50 & 2,18 & 231 & 83 & 38 & 92 & 126 & 497 \\
\hline
\end{tabular}

Tabela V.13 - Resultados das análises químicas totais para as amostras coletadas nos perfis do Afloramento de Pirapora (Área - 3).

\section{Análises Químicas Pontuais}

Para a realização das análises químicas pontuais, em MEV/EDS, nos materiais coletados no afloramento de Pirapora, foram utilizadas lâminas delgadas confeccionadas com as amostras representativas das crostas ferruginosas, da matriz e da porção sem "dobras" do afloramento.

Os resultados das análises químicas pontuais em MEV/EDS demonstraram que os materiais analizados são de uma maneira geral, compostos predominantemente por silício $(\mathrm{Si})$, alumínio $(\mathrm{Al})$ e ferro $(\mathrm{Fe})$ e, subordinadamente, por magnésio $(\mathrm{Mg})$, sódio $(\mathrm{Na})$, cálcio $(\mathrm{K})$, potássio $(\mathrm{K})$ e titânio $(\mathrm{Ti})$. O manganês $(\mathrm{Mn})$ ocorre somente nas amostras pertencentes a crosta em concentrações reduzidas.

No plasma dos materiais das crostas, observou-se uma concentração mais elevada de ferro e, no plasma da matriz, predominam o silício e o alumínio. O plasma observado nas amostras da porção sem "dobras" do afloramento apresenta uma composição intermediária, sendo que em algumas amostras observou-se certa concentração de ferro. 
intermediária, sendo que em algumas amostras observou-se certa concentração de ferro.

Através da realização de uma análise pontual qualitativa em sequência, atravessando o plasma da região das crostas, detectou-se que em microfissuras preenchidas por material escuro, o teor de ferro é elevado. Isto ocorre devido a presença de óxidos e hidróxidos de ferro.

Observou-se também nestes materiais a existência de concentrações plásmicas de coloração esbranquiçada, onde os teores de ferro são bastante elevados (Figuras V.60 a V.64).

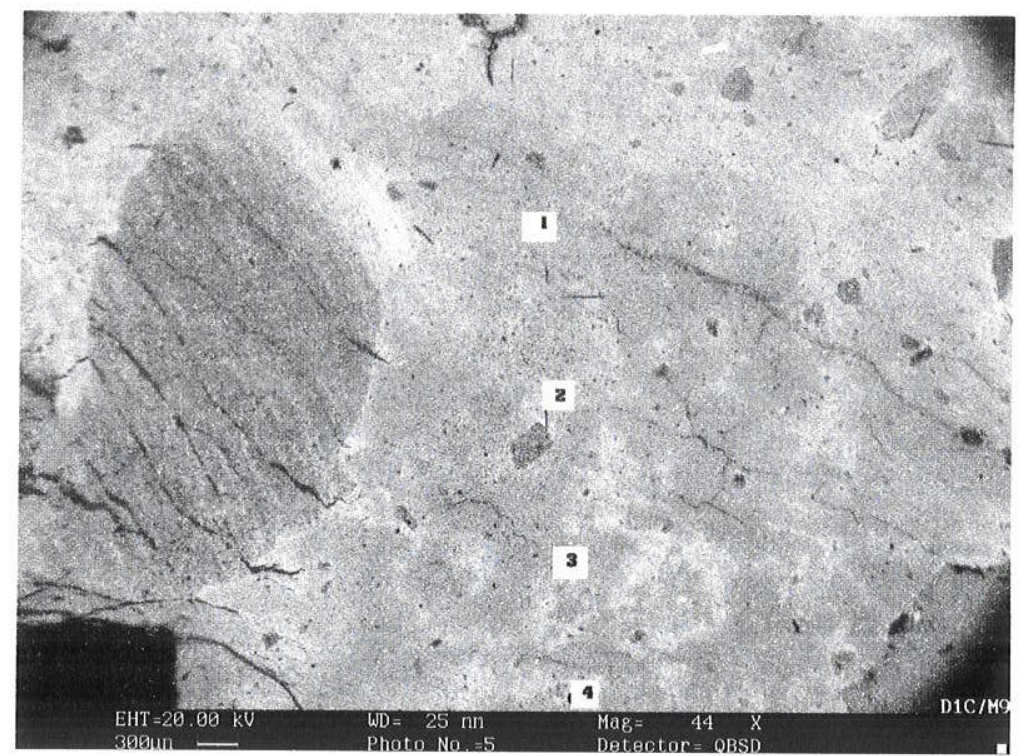

Figura V.60 - Imagem em MEV Aspecto geral do plasma das crostas (afloramento de Pirapora), exibindo fissuras preenchidas por hidróxidos de ferro a direita, e litorelíquia (fragmento de rocha) a esquerda. Pontos 1, 2, 3 e 4 - análise pontual qualitativa em sequência .

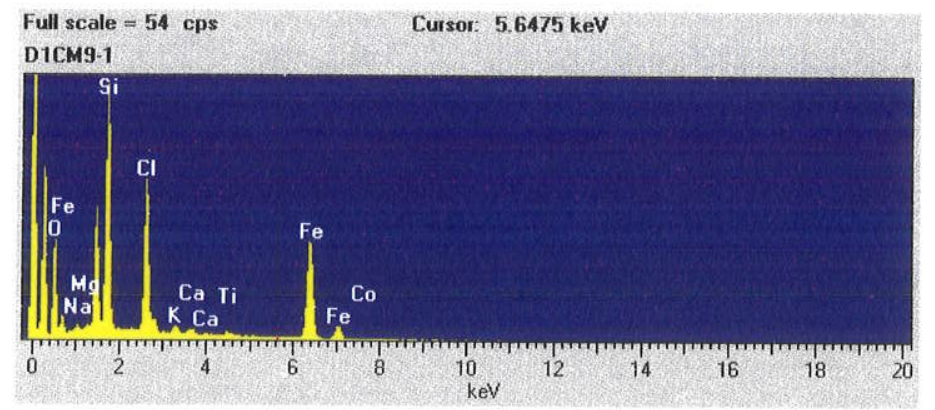

Figura V.61 - Espectro de EDS do ponto 1 da imagem V.60, com análise qualitativa. Destacam-se principalmente os picos do silício (Si), do ferro (Fe) e do oxigênio $(\mathrm{O})$ (região da crosta). Já os picos do titânio $(\mathrm{Ti})$, potássio $(\mathrm{K})$, sódio $(\mathrm{Na})$, cálcio $(\mathrm{Ca})$ e magnésio $(\mathrm{Mg})$ aparecem menos acentuados. O pico do cloro $(\mathrm{Cl})$ provém da resina utilizada na impregnação dos materiais para a confecção das lâminas delgadas.

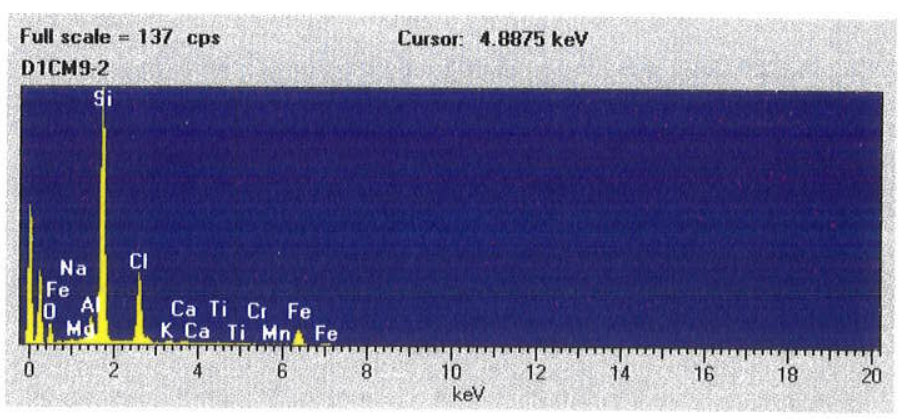

Figura V.62 - Espectro de EDS do ponto 2 da imagem V.60, com análise qualitativa. Destacam-se principalmente os picos do silício (Si), do ferro (Fe) e do oxigênio (O) (região da crosta). Os picos do alumínio $(\mathrm{Al})$, titânio $(\mathrm{Ti})$, potássio $(\mathrm{K})$, sódio $(\mathrm{Na})$, cálcio $(\mathrm{Ca})$, magnésio $(\mathrm{Mg})$,e manganês $(\mathrm{Mn})$ aparecem menos acentuados. O pico de cloro (Cl) provém da resina utilizada na impregnação dos materiais para a confecção das lâminas delgadas. 


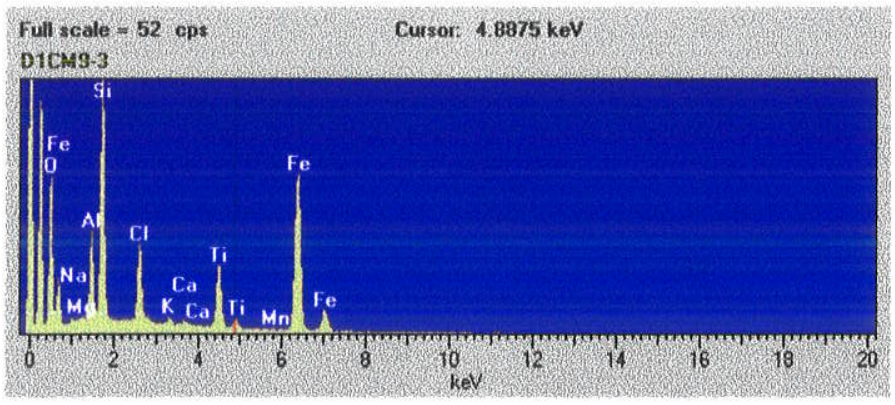

Figura V.63 - Espectro de EDS do ponto 3 da imagem V.60, com análise qualitativa. Destacam-se principalmente os picos do silício $(\mathrm{Si})$, do ferro $(\mathrm{Fe})$ do titânio (Ti) e do oxigênio $(\mathrm{O})$ (região da crosta). Os picos de alumínio $(\mathrm{Al})$, potássio $(\mathrm{K})$, sódio $(\mathrm{Na})$, cálcio $(\mathrm{Ca})$, magnésio $(\mathrm{Mg})$ e manganês $(\mathrm{Mn})$ aparecem menos acentuados. O pico do cloro $(\mathrm{Cl})$ provém da resina utilizada na impregnação dos materiais para a confecção das lâminas delgadas.

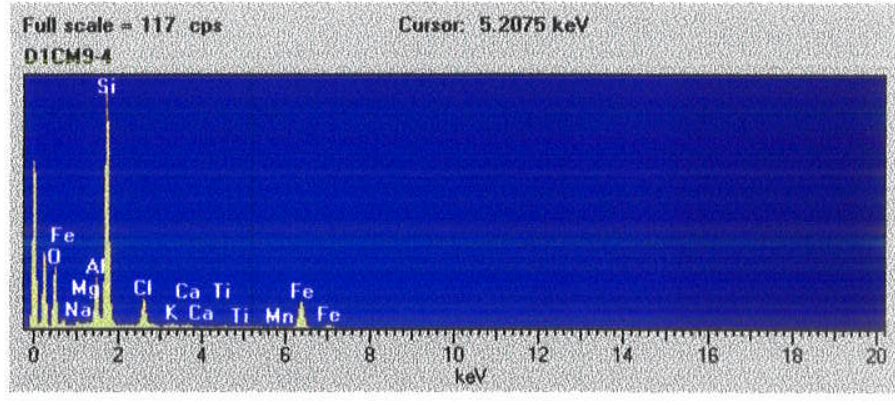

Figura V.64 - Espectro de EDS do ponto 4 da imagem V.60, com análise qualitativa. Destacam-se principalmente os picos do silício (Si), do ferro $(\mathrm{Fe})$ e do oxigênio $(O)$ (região da crosta). Os picos de alumínio (Al), titânio (Ti), potássio (K), sódio $(\mathrm{Na})$, cálcio $(\mathrm{Ca})$, magnésio $(\mathrm{Mg})$ e manganês $(\mathrm{Mn})$ aparecem menos acentuados.

A figura V.65 exibe a imagem em MEV do aspecto geral do plasma encontrado na região da matriz. Este plasma é constituído basicamente por silício e alumínio (Figura V.66). Concentrações plásmicas, enriquecidas em ferro, foram encontradas nestes materiais, embora pouco frequentes, aparecendo como manchas esbranquiçadas.
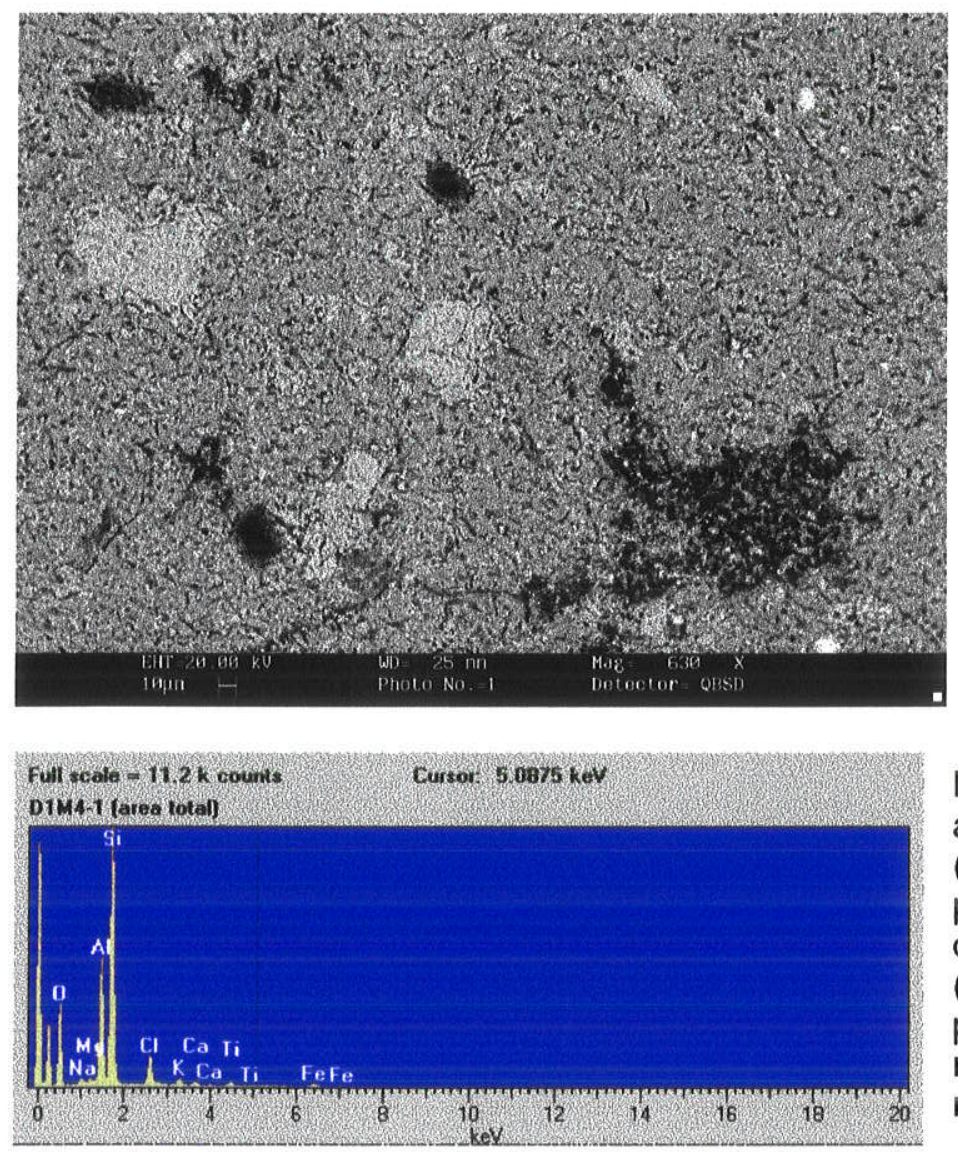

Figura V.65 - Imagem em MEV Aspecto geral da matriz (Afloramento de Pirapora).

Figura V.66 - Espectro de EDS com análise qualitativa da região da matriz (Figura V.65). Destacam-se principalmente os picos do silício $(\mathrm{Si})$, do alumínio (Al) e do oxigênio (O) (matriz). Os picos de titânio (Ti), potássio $(\mathrm{K})$, sódio $(\mathrm{Na})$, cálcio $(\mathrm{Ca})$, magnésio $(\mathrm{Mg})$ e ferro $(\mathrm{Fe})$ aparecem menos acentuados. 
Concentrações de plasma argiloso deferruginizado são comuns na interface entre os plasmas das crostas e da matriz. Aparecem como manchas escuras, em alto relevo, circundada por plasma de coloração mais clara (Figura V.67).

Estas concentrações foram descritas supostamente como sendo nódulos de fuga de hidróxidos de ferro, uma vez constatado nas análises pontuais, que estas regiões possuem menor concentração de ferro em comparação com a do plasma que as circundam (Figuras V.68 e V.69).

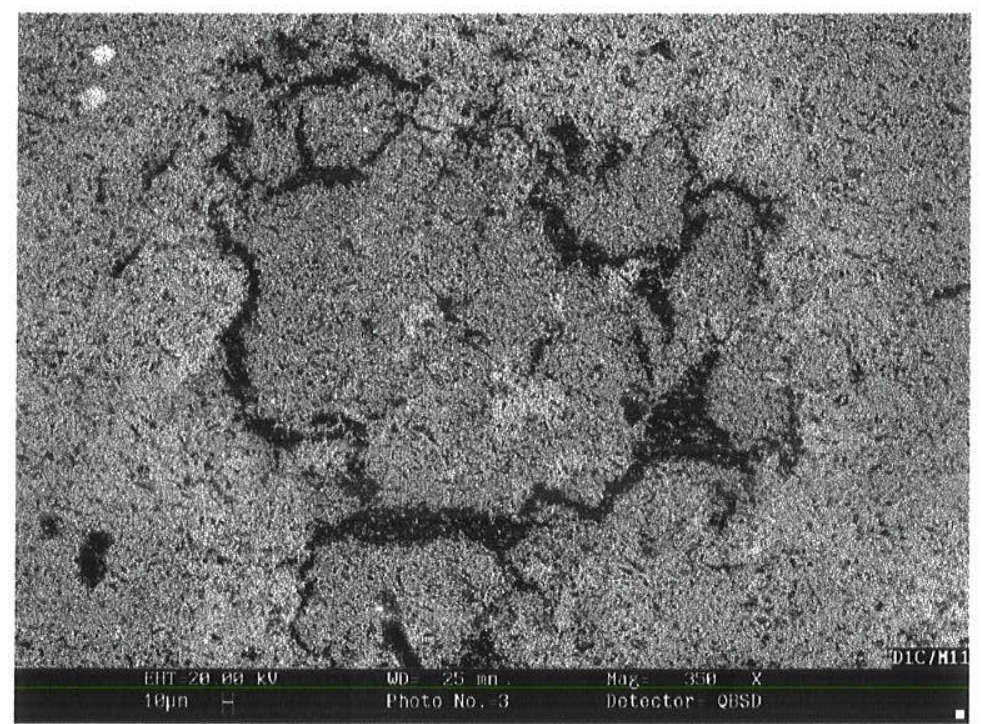

Figura V.67 - Imagem em MEV exibindo concentraçãos de plasma argiloso deferruginizado (porção mais escura no centro da imagem) (nódulos de fuga de hidróxidos de ferro). Interface crosta / matriz (afloramento de Pirapora).
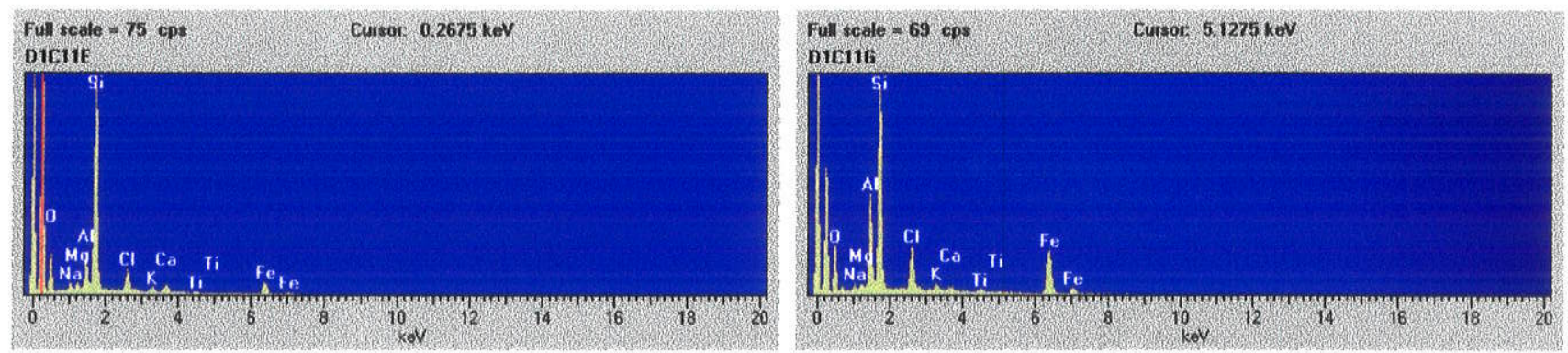

Figura V.68 - Espectro de EDS com análise pontual qualitativa da região escura no centro da imagem V.67. Destaque para a baixa concentração de ferro (Fe) (pico reduzido), indicando fuga de hidróxido de ferro nesta região. São observados picos do silício (Si), alumínio $(\mathrm{Al})$, titânio $(\mathrm{Ti})$, potássio $(\mathrm{K})$, sódio $(\mathrm{Na})$, cálcio $(\mathrm{Ca})$, magnésio $(\mathrm{Mg})$, oxigênio $(\mathrm{O})$.
Figura V.69 - Espectro de EDS com análise pontual qualitativa da região mais clara da imagem V.67. Destaque para a concentração mais elevada de ferro (Fe). São observados picos do silício (Si), alumínio $(\mathrm{Al})$, titânio (Ti), potássio $(\mathrm{K})$, sódio $(\mathrm{Na})$, cálcio (Ca), magnésio $(\mathrm{Mg})$, oxigênio $(\mathrm{O})$. 
A amostras da porção sem "dobras" do afloramento caracterizam-se por apresentarem dois materiais distintos; um esbranquiçado, argiloso (caolinítico) ocorrendo geralmente na forma de nódulos e outro mais escuro, constituído predominantemente por argila contendo hidróxidos de ferro.

As análises em MEV/EDS indicaram que os materiais esbranquiçados constituintes dos nódulos argilosos são compostos predominantemente por plasma enriquecido em silício e alumínio, e o plasma escuro mais enriquecido em hidróxidos de ferro (Figuras V.70 e V.71).

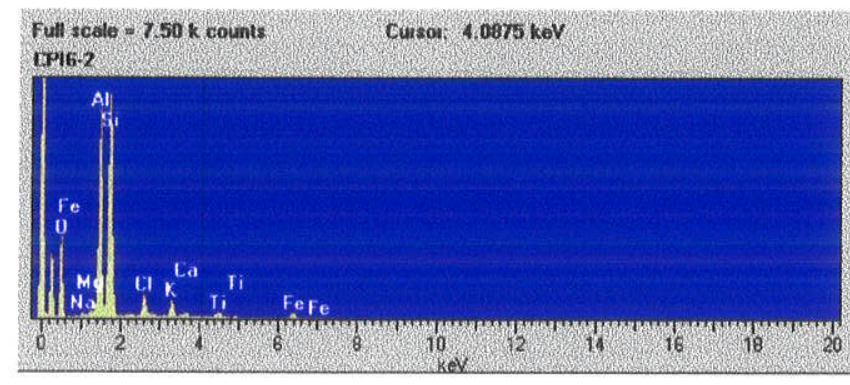

Figura V.70 - Espectro de EDS com análise qualitativa do plasma esbranquiçado da porção sem "dobras" do afloramento de Pirapora. Destacam-se os picos do silício (Si), do alumínio $(\mathrm{Al})$ e do oxigênio (O). Nota-se também, baixa concentração de ferro (Fe). Os picos de titânio $(\mathrm{Ti})$, potássio $(\mathrm{K})$, sódio $(\mathrm{Na})$, cálcio $(\mathrm{Ca})$ e magnésio $(\mathrm{Mg})$ aparecem menos acentuados.

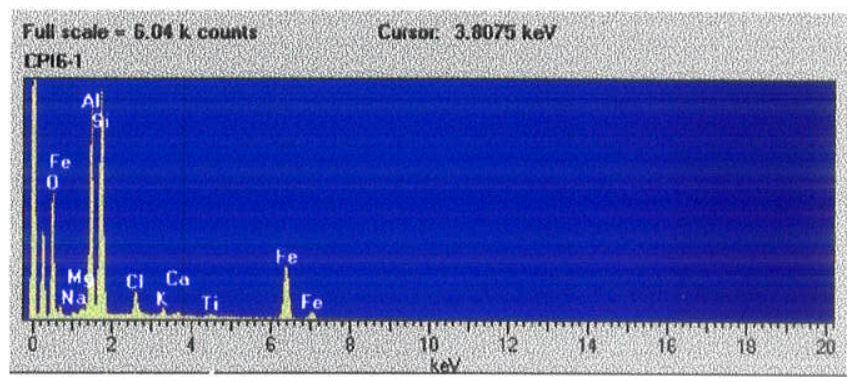

Figura V.71 - Espectro de EDS com análise qualitativa do plasma escuro da porção sem "dobras" (Pirapora). Destaque para a elevação do pico de ferro (Fe) e para os picos do silício (Si), do alumínio (Al) e do oxigênio $(\mathrm{O})$. Os picos de titânio (Ti), potássio $(\mathrm{K})$, sódio $(\mathrm{Na})$, cálcio $(\mathrm{Ca})$, e magnésio $(\mathrm{Mg})$ ) aparecem menos acentuados.

A figura V.72 exibe a imagem em MEV do aspecto geral do plasma encontrado nos materiais da porção sem "dobras" do afloramento de Pirapora. Observa-se série de fissuras ora preenchidas por material esbranquiçado, ora por material escuro.

Através de análise química pontual qualitativa foi possível a identificação da composição dos materiais que preenchem estas fissuras. Constatou-se que o material esbranquiçado (ponto 1, figura V.72) constitui-se por plasma mais enriquecido em hidróxidos de ferro (Figura V.73).

O material mais escuro representa dois plasmas distintos; um menos enriquecido em hidróxidos de ferro (predomínio de silício e alumínio-ponto 2, figura V.72) e outro mais enriquecido neste hidróxidos (ponto 4, figura V.72) (Figuras V.74 e V.75). 
O plasma acinzentado da região sem fissura da figura V.72 (ponto 3) é mais empobrecido em hidróxidos de ferro, predominando o silício e o alumínio (Figura V.76).

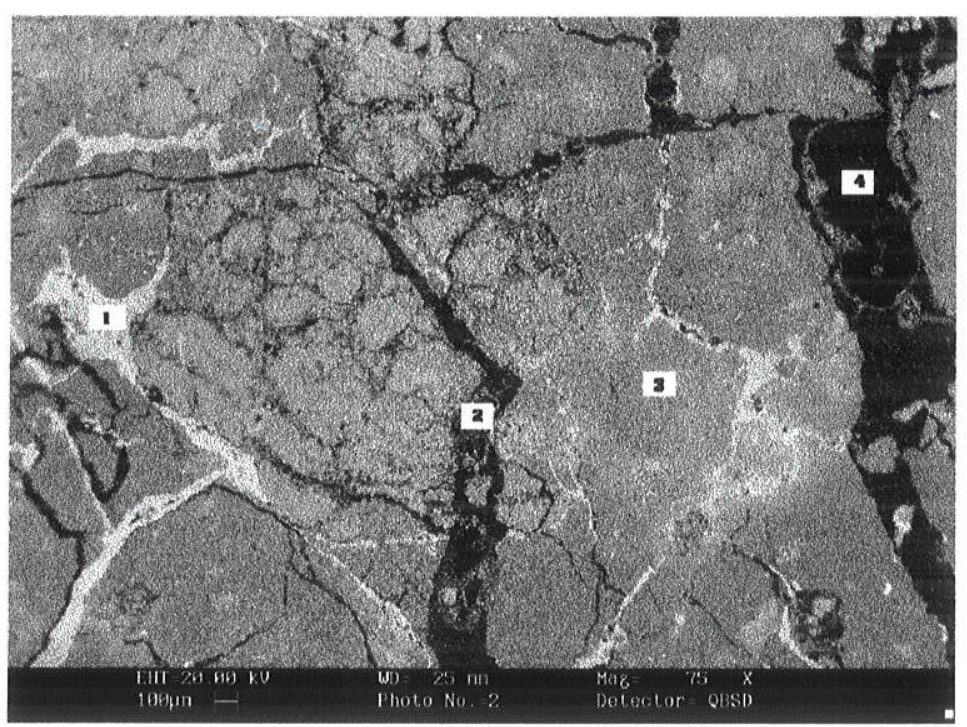

Figura V.72 - Imagem em MEV Aspecto geral do plasma da porção sem "dobras" do afloramento de Pirapora, exibindo fissuras preenchidas por hidróxido de ferro e por material silico aluminoso. Pontos 1, 2, 3 e 4 - análise pontual qualitativa em sequência.

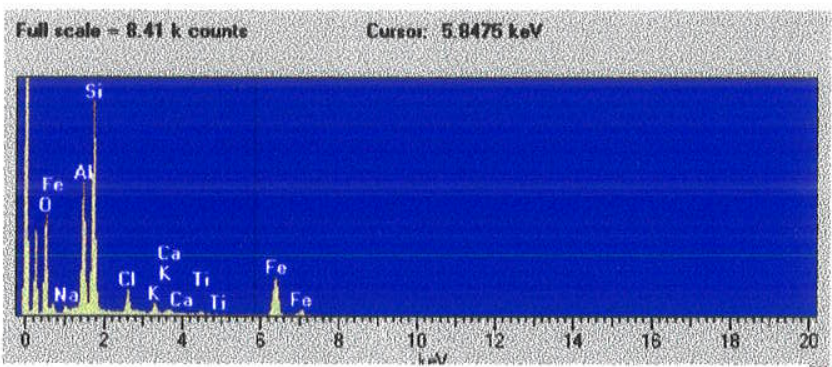

Figura V.73 - Espectro de EDS com análise qualitativa do material que preenche a fissura no ponto $1 \mathrm{da}$ imagem V.7. Destacam-se os picos do silício (Si), do alumínio (Al) e do oxigênio (O). Nota-se elevação do pico de ferro $(\mathrm{Fe})$. Os picos de titânio (Ti), potássio $(\mathrm{K})$, sódio $(\mathrm{Na})$ e cálcio (Ca) aparecem menos acentuados.

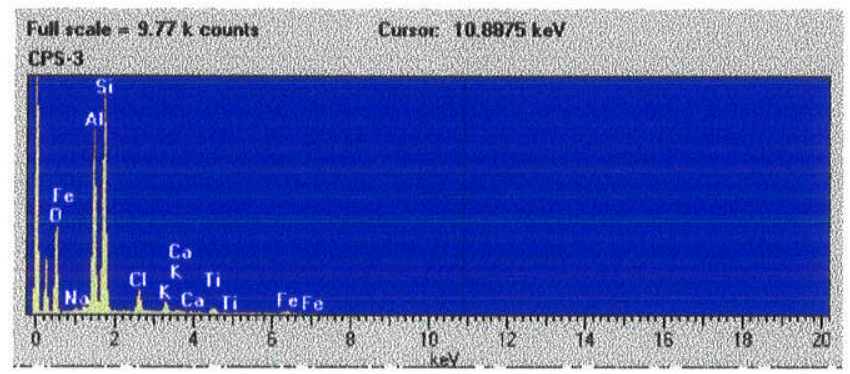

Figura V.75 - Espectro de EDS com análise qualitativa do material que preenche a fissura no ponto 3 da imagem V.7. Destacam-se os picos do silício (Si), do alumínio ( $\mathrm{Al}$ ) e do oxigênio (O) (principais constituíntes deste material). Os picos de ferro $(\mathrm{Fe})$, titânio $(\mathrm{Ti})$, potássio $(\mathrm{K})$, sódio $(\mathrm{Na})$ e cálcio (Ca) aparecem menos acentuados.

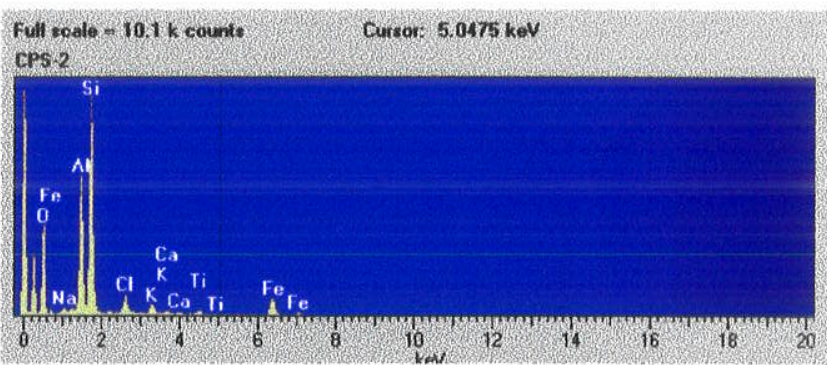

Figura V.74 - Espectro de EDS com análise qualitativa do material que preenche a fissura no ponto 2 da imagem V.7. Destacam-se os picos do silício (Si) e do alumínio (Al) e do oxigênio (O). Os picos de ferro ( $\mathrm{Fe})$, titânio (Ti), potássio (K), sódio $(\mathrm{Na})$ e cálcio $(\mathrm{Ca})$ aparecem menos acentuados.

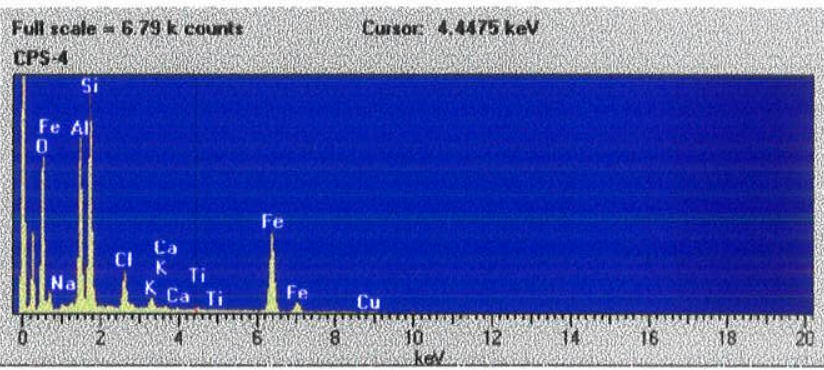

Figura V.76 - Espectro de EDS com análise qualitativa do material que preenche a fissura no ponto 4 da imagem V.7. Destacam-se os picos do silício (Si), do alumínio (Al), e do oxigênio $(\mathrm{O})$. Nota-se elevação do pico de ferro ( $\mathrm{Fe}$ ). Os picos de titânio (Ti), potássio $(\mathrm{K})$, sódio $(\mathrm{Na})$, cálcio (Ca) aparecem menos acentuados. 


\section{1 - ANÁLISE ESTRUTURAL}

A análise estrutural foi realizada a partir de dados coletados das estruturas encontradas nos afloramentos da Vila Madalena (Área - 2) e Pirapora (Área - 3). Não foi realizada análise estrutural nas estruturas dos afloramentos da Rodovia Presidente Dutra (Área 1) devido ao avançado estágio de alteração em que se encontravam os materiais, dificultando a obtenção de medidas bem como serem essas estruturas encontradas pouco representativas quando comparadas com as das outras áreas. Outro fator que impossibilitou a realização da análise estrutural nos afloramentos da Dutra, foi a destruição dos mesmos durante obras de duplicação da rodovia.

\section{Afloramento da Rua Girassol - Vila Madalena, SP (Área - 2)}

Neste afloramento foram obtidas medidas estruturais somente das crostas deformadas encontradas no lado esquerdo do mesmo (Figuras III. 9, III.10 e III.11). O avançado estágio de alteração das crostas impossibilitou a realização destas medidas no restante do afloramento.

A análise estrutural, neste caso, foi realizada apenas com o intuito de verificar se as crostas dobradas forneceriam algum padrão de dobramento conhecido na região ou não. As observações de campo permitiram inserir estes dobramentos em contexto geológico bem definido, favorecendo descartar em princípio uma hipótese tectônica para sua origem.

Para a caracterização morfológica das "dobras", encontradas no afloramento em questão, foram extraídas as direções dos flancos, utilizando-se a bússola convencional de geólogo (Tabela V.1.1). Os dados recolhidos em campo foram tratados nos softwares QuickPlot e Stereonet, e confeccionados esterogramas Schimdt Lambert (Figura V.1.1).

O tipo de dobramento identificado representa um antiforme, cujos flancos possuem direção norte (N) e mergulho para sudeste (SE) (flanco direito) e noroeste (NW) (flanco esquerdo). 


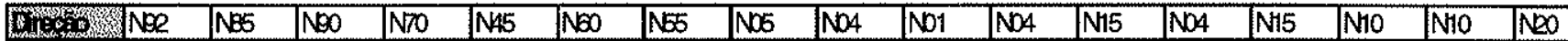

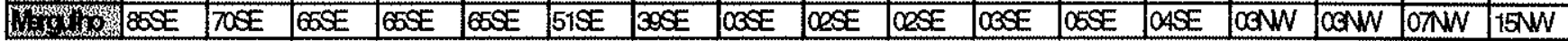

Tabela V.1.1 Medidas Estruturais das Dobras Levantadas em Campo

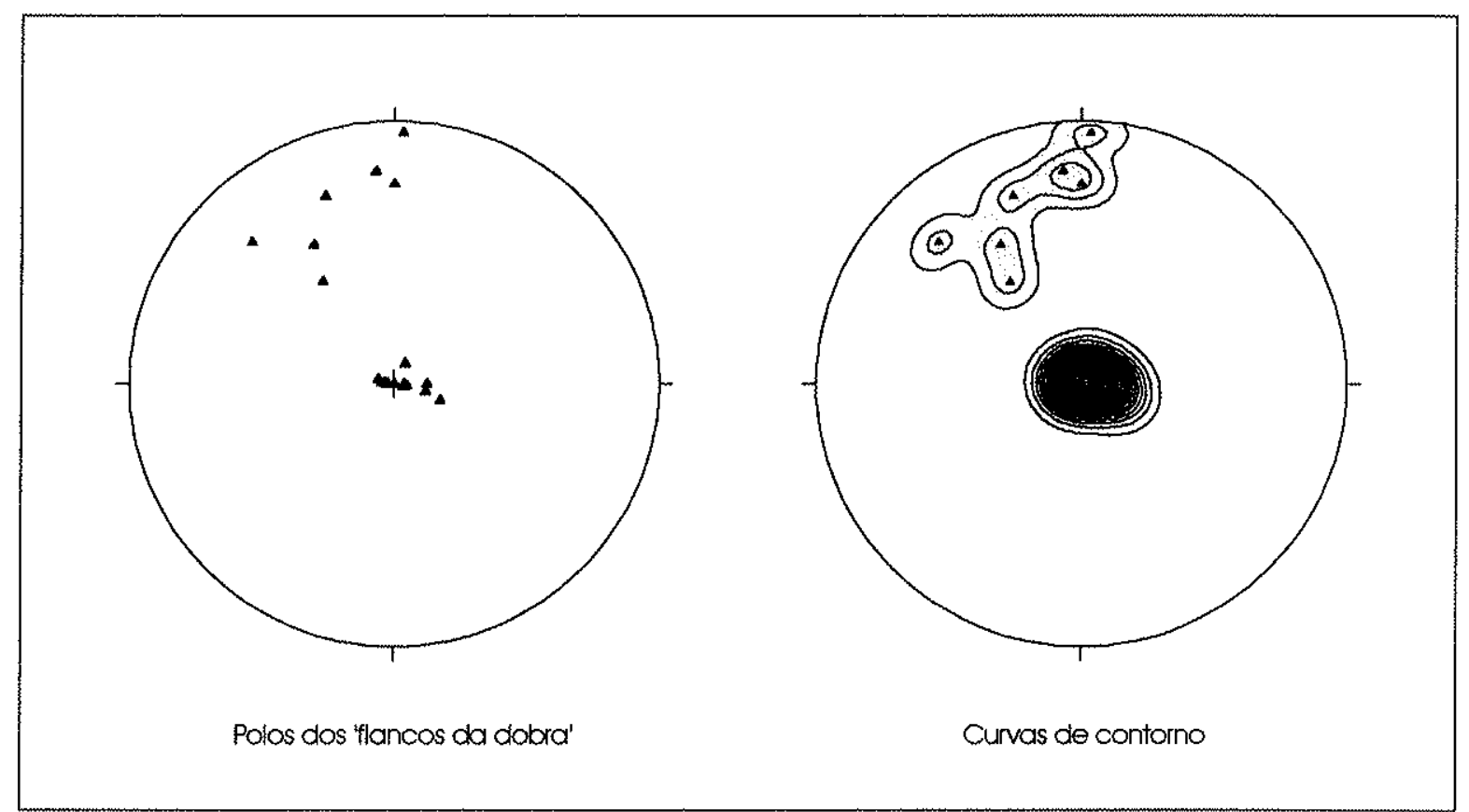

Figura V.1.1 - Estereogramas Schimdt Lambert construídos com os dados levantados no afioramento da Vila Madalena (Área-2).

\section{Afloramento da Estrada dos Romeiros - Pirapora do Bom Jesus (Área - 3)}

A descrição das estruturas dobradas, encontradas no afloramento de Pirapora do Bom Jesus, não priorizou critérios de superposição e interferência entre as dobras $e$ as fraturas, pois tais procedimentos só poderiam ser utilizados caso comprovado que as dobras são inequivocamente de origem tectônica.

Neste trabalho, empregou-se o agrupamento das estruturas por "grupos de estilo" (Hobbs et al., 1976), procedimento este que não associa necessariamente feições estruturais de mesma geração.

Os planos de fraturas e de flancos de dobra foram tratados separadamente. As fraturas foram tratadas em estereograma e a partir da literatura pertinente (Bistrichi, 1992), foram extraídos dados de lineação. 
Esses dados foram tratados em software Quickplot e confecionados estereogramas. As dobras foram divididas em anticlinais, sinclinais e dobras chamadas de representativas, por não apresentarem nenhuma fratura que pudesse interferir em sua posição de dobramento original.

A partir de estereogramas confeccionados por Bergmann (1988) e Bistrich (1982), foi realizada tentativamente a inserção dos estereogramas confeccionados neste trabalho no contexto estrutural dos trabalhos pertinentes a região.

\section{Juntas e Fraturas}

No contexto da análise das fraturas, nota-se a existência de quatro (04) grupos distintos, com lineamentos de mesma direção (Figura III.13).

Um grupo é formado por fraturas únicas (F2, F3, F4 e F5 da Figura III.13) com aberturas espessas ( $\geq 5 \mathrm{~cm}$ de largura), ora preenchidas por hidróxido de ferro (G1), ora sem preenchimento (G2).

Outro grupo (G3) é composto por fraturas múltiplas agrupadas com 2, 3 e 5 elementos, pouco espessas, preenchidas por hidróxidos de ferro (F6, F8/F9 da Figura III.13). Estes grupos limitam a morfologia das dobras.

Um quarto grupo (G4) constitui-se por pequenas falhas, com rejeitos normais e valores de deslocamento não maiores que $20 \mathrm{~cm}$. Pela visualização das intersecções, concluise que estas falhas são posteriores ao dobramento e as fraturas (F7 e F10 da Figura III. 13).

Com propósito comparativo entre os dados conhecidos da literatura para a área e os dados obtidos neste trabalho, torna-se necessária a inclusão de alguns termos utilizados e descritos por Bergmann (1988). Na descrição dos elementos estruturais associados ao dobramento, a autora divide os elementos estruturais em $\sin$, tardi e pós-metamórficos. Dentre os elementos estruturais sin-metamórficos encontram-se:

- $S_{1:}$ foliação representada pela orientação planar de minerais micáceos.

- $S_{2}$ : foliação bem desenvolvida, muitas vezes obliterando de maneira total, ou como clivagem de crenulação tardia, a foliação $S_{1}$. Nas regiões de flanco normal de grandes 
dobras da segunda fase, $S_{2}$ tende a ser clivagem oblíqua à subparalela às dobras com mergulhos mais acentuados.

Como elementos estruturais tardios ao metamorfismo Bergmann (1988), observa :

- $S_{3:}$ clivagem de crenulação apresentando-se em afloramentos de metapelitos como clivagem espaçada planomaxial a dobras abertas milimétricas a centimétricas da superfície $S_{2}$

- $L_{3}$ : lineação visível no plano $S_{2}$ como lineação de intersecção de espaçamento variável, milimétrico a centimétrico.

O estereograma confeccionado a partir dos dados de juntas e fraturas (Figura V.1.2), recolhidas em campo, apresentam orientação principal NE-SW com mergulhos altos entre $90^{\circ}$ e $65^{\circ}$ e espaçamentos decimétricos.

O resultado do estereograma dos dados obtidos nesta dissertação e recolhidos no afloramento desta área, apresentam-se basicamente idênticos ao estereograma para clivagem tardia (de crenulação) pós $S_{3}$ no Domínio $E$, apresentado por Bergmann (1988) (Figura V.1.3).

A autora considerou o Domínio $\mathrm{E}$ como sendo o extrado do flanco $\mathrm{N}$ do Sinclinório de Pirapora, comportando o membro pelítico da Formação Estrada dos Romeiros, com ampla faixa de afloramento dos filitos.

As clivagens posteriores a $S_{3}$ apresentam-se em nível crustal raso com pouca continuidade, em planos espaçados de $2-3 \mathrm{~cm}$, preenchidos por hidróxidos de ferro, dando origem a uma lineação de intersecção grosseira no plano chamado de $S_{2}$, que corta a lineação denominada $L_{3}$. (Bergmann, 1988). Assim, pode-se ponderar que estes elementos talvez tenham uma mesma origem.

O que Bistrichi (1982) considera como clivagem de crenulação é uma feição penetrativa, tanto em escala mesoscópica quanto microscópica, e está sobreposta a clivagem anterior, definida normalmente em minerais placóides. Portanto, os filitos e os xistos são as rochas onde podem ser melhor observada. $O$ que o autor considera como 
clivagem de fratura não é uma estrutura penetrativa em escala mesoscópica, porém está relacionada a dobramentos.

Esta feição é constituída por microfalhas ou fraturas, muito próximas entre si, que dividem a rocha em um conjunto de corpos tabulares. A clivagem de fratura afeta, principalmente, os quartzitos, calcários e dolomitos. Por serem feições regionais, e por estarem possivelmente em outros membros, ou ainda, por terem sido originados em eventos diferentes, os estereogramas polares confeccionados (Figuras V.1.4 e V.1.5) não apresentaram coincidência com os estereogramas confeccionados com os dados do afloramento estudado.

O estereograma para os dados de clivagem de crenulação apresenta poucos dados coincidentes com o estereograma das fraturas relacionadas as dobras estudadas. Não foi possivel, então, tecer uma correlação entre estes elementos. 


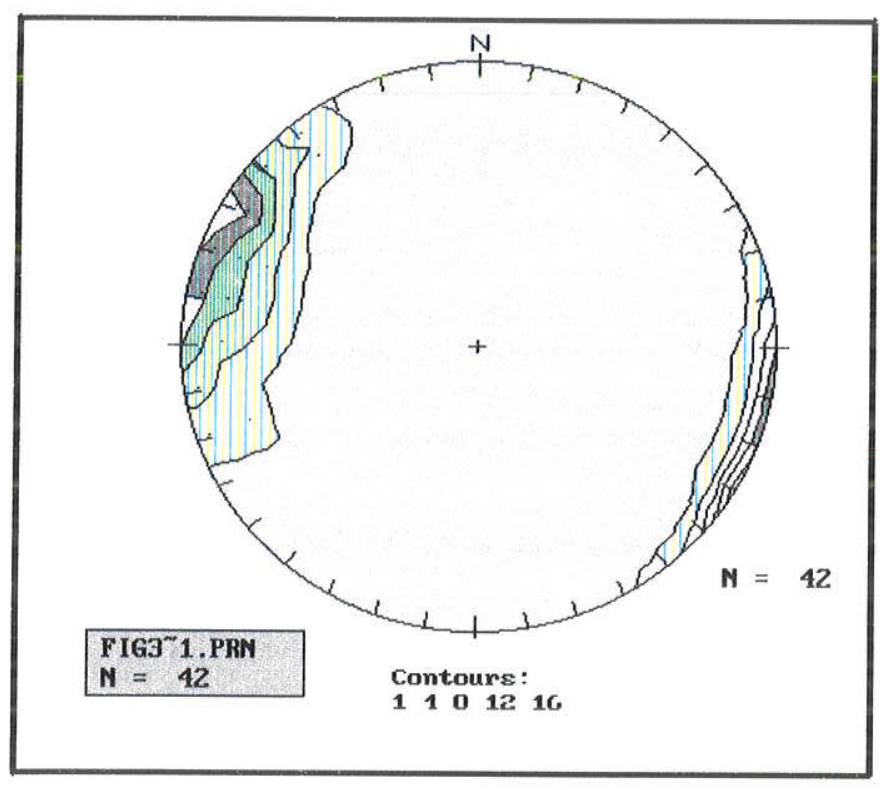

Figura V.1.2 - Estereograma para dados de fraturas do afloramento (Pirapora - Área 3).

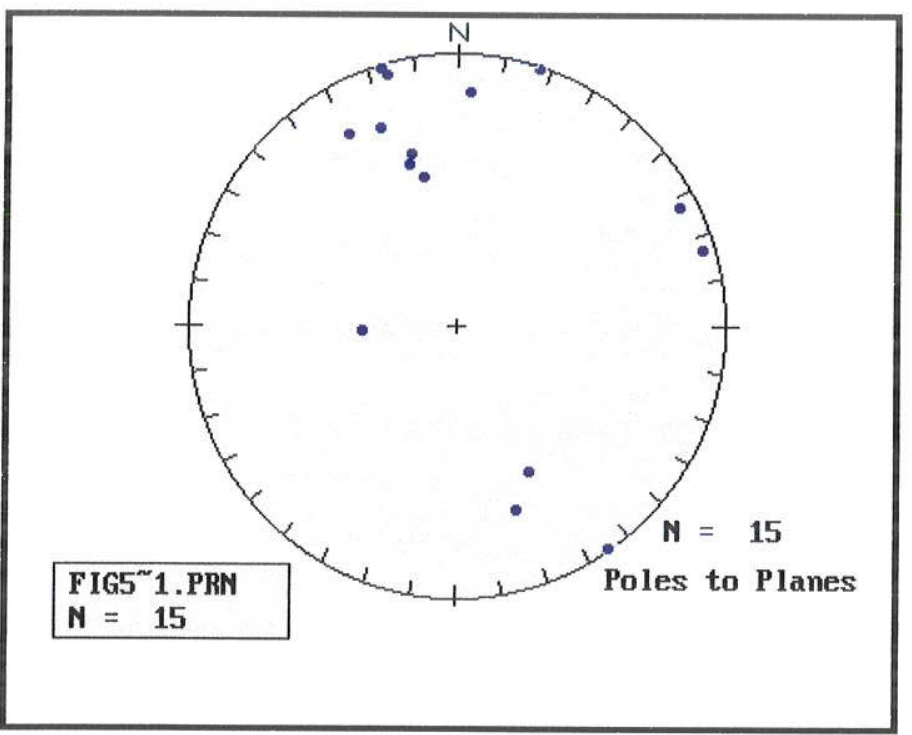

Figura V.1.4 - Estereograma Schimdt Lambert para clivagens de fratura, confeccionados a partir de dados extraídos de Bistrichi (1982) (Pirapora - Área 3).

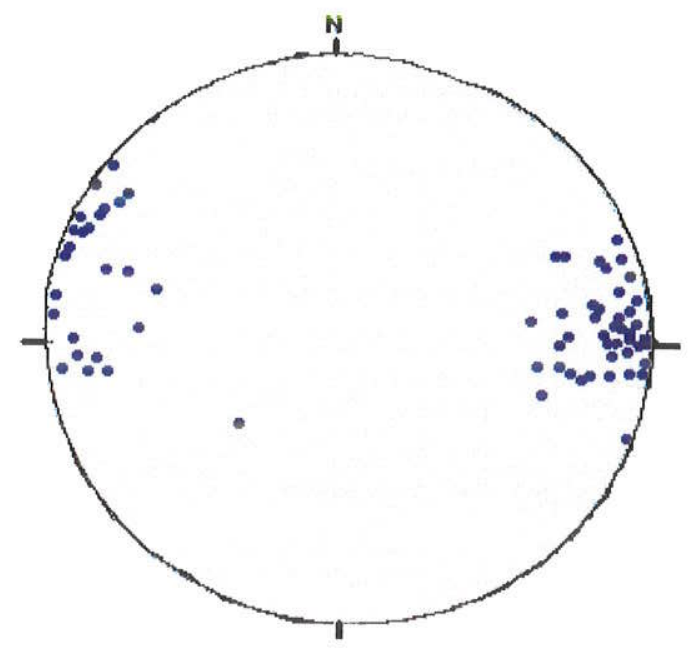

Figura V.1.3 - Estereograma Schimdt-Lambert para a clivagem tardia pós $S_{3}$ no domínio $E$. (Extraído de Beramann. 1988) (Pirapora - Área 3).

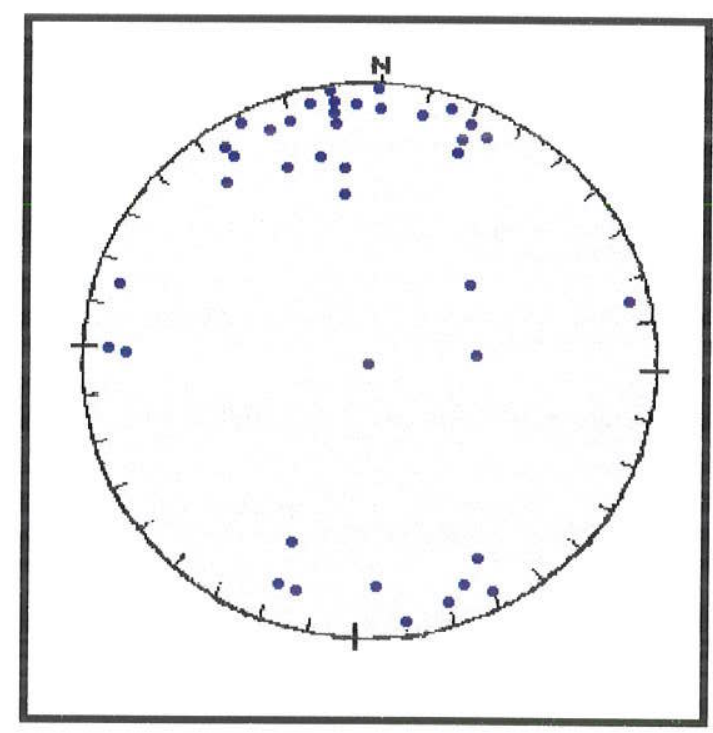

Figura V.1.5- Diagrama de Schimdt-Lambert (pólos de clivagem de crenulação), dados de Bistrichi (1982) (Pirapora - Área 3).

\section{Dobras}

Como ocorre em grande parte dos sistema de dobras naturais, as estruturas analisadas neste trabalho não apresentam periodicidade nem simetria, tornando imprópria a 
definição de parâmetros como amplitude e comprimento de onda (Fleuty, 1964 apud Hobbs et al., 1976). Entretanto, estas estruturas não passam de valores decamétricos. Vale ressaltar também, que as dobras menores não ocorrem como dobras parasitas em relação as maiores.

A descrição da morfologia das dobras está ligada à aparência do perfil (Hobbs et al.,1976). Uma descrição apurada sobre o aspecto das dobras é bastante complicada neste caso, já que essas sofrem variações irregulares no perfil. No geral, pode ser considerado um sistema de dobras desarmônicas, apresentando ora dobras angulares, ora dobras arredondadas (termos relacionados ao fechamento das dobras).

Diante das condições de avançado intemperismo do afloramento, não foi possivel a tomada de medidas dos eixos e, consequentemente, de superfícies axiais. Aparentemente as superfícies axiais estão representadas pelas fraturas e juntas, paralelas entre si.

\section{Análise dos Estereogramas}

Foram confeccionados estereogramas equiários para os pólos das superfícies "dobradas".

A projeção equiária representando todas as dobras (Figuras V.1.6 e V.1.7) exibiu os pólos das superfícies distribuídos em uma linha preferencial E-W. Isto poderia ser interpretado como uma dobra horizontal cilíndrica com orientação N-S, sendo que o eixo gerador construído estaria orientado a $\mathrm{S} 13 \mathrm{~W} / 4^{\circ}$. Tal tipo de dobramento incomum não corresponde a nenhum padrão estrutural apresentado na região por outros autores (Bistrichi, 1982 e Bergmann, 1988), levando a separação dos dados e a confecção de outros estereogramas, afim de facilitar a interpretação do padrão geométrico das estruturas.

Primeiramente, as dobras foram separadas em anticlinais e sinclinais. Sendo 0 afloramento constituído em grande parte por dobras anticlinais, a sua representação diagramática (Figuras V.1.8 e V.1.9) ficou quase idêntica àquela apresentada por todos os flancos do afloramento. Os estereogramas confeccionados a partir dos poucos dados das dobras sinclinais (Figuras V.1.10 e V.1.11), não apresentaram nenhum 
padrão de dobramento, impossibilitando a construção de guirlandas ou eixos construídos.

Optou-se, então, pela escolha de um setor no afloramento em que as dobras não estivessem em contato com nenhuma "falha" (fratura) que as deslocassem. Foi escolhida, portanto, uma área compreendida entre as linhas F4 (fratura) e DI (Figura III. 13).

Os diagramas resultantes das projeções dos pólos (Figuras V.1.12, V.1.13, V.1.14 e V.1.15) das superfícies das dobras, pertencentes a esta área também apresentaram maiores concentrações de pólos no eixo E-W, de forma mais dispersa. Pode-se considerar que os pólos se concentram em um círculo mínimo, representando um padrão de dobras cônicas (Stauffer, 1964 apud Hobbs, 1976). A geratriz construída, neste caso, está orientada totalmente a norte $(\mathrm{N})$ com mergulho sub-horizontal.

A comparação entre este resultado com o apresentado em estudos regionais anteriores da região também não exibiu nenhuma coincidência de padrão.

Bistrichi (1982), em seu trabalho de mapeamento da região, realizou uma descrição em termos de grupos de dobras, reconhecendo três eventos $\left(D_{1}, D_{2} \in D_{3}\right)$.

O evento mais antigo é o grupo de dobras $D_{1}$, observado em toda área de seu estudo, caracterizado por superfície axial representada por foliação do tipo clivagem ardosiana. Os fechamentos destas dobras são raramente observáveis, quando o são encontramse geralmente apertados.

As dobras $D_{2}$ são mais facilmente reconhecidas e caracterizam-se por exibir clivagem ardosiana dobrada. Em afloramento, estas dobras mostram uma variação quanto a escala (desde dobras centimétricas até decamétricas), sendo geralmente cilíndricas com estilos variados. Em perfil, estas variam de dobras abertas a fechadas apresentando frequentemente ápices arredondados a subangulosos, porém como conjunto podem ser consideradas dobras harmônicas (Bistrichi, 1982).

Dobras maiores relacionadas a $\mathrm{D}_{2}$ foram reconstruídas por Bistrichi (1982), através de medidas tomadas em afloramento. No geral, as dobras $D_{2}$, apresentam eixos subhorizontais a horizontais. No entanto, a oeste de Pirapora do Bom Jesus, seus eixos 
apresentam-se enclinados até $40^{\circ}$. A orientação dos planos axiais é pouco variada, com mudança marcante da porção ocidental para as porções central e oriental. Há para W predominância segundo a direção N60E, enquanto que para leste predomina a tendência E-W. A NNE de Pirapora estão caracterizadas assimetrias em "S" e "Z", configurando sucessão de antiformas e sinformas.

As dobras $D_{3}$, observadas em apenas alguns setores da área estudada por Bistrichi (1982), apresentam-se em afloramento como dobras suaves, isópacas de dimensões centimétricas até métricas, com eixos sub-horizontais, orientados segundo N-S, a NNESSW, inclinados até $40^{\circ}$.

Por outro lado, Bergmann (1988), atribui a região cinco fases de dobramentos superimpostos; três delas sin a tardi-metamórficas e duas pós-metamórficas.

Para a primeira fase não foram identificadas dobras em escala de afloramento, porém reflete-se na persistência de uma clivagem ardosiana paralela ao acamamento nos metassedimentos. A segunda fase de dobramento desenvolve dobras isoclinais, recumbentes, com flanco invertido de pequena extensão, não sendo porém caracterizada como nappes. A vergência para esta fase é NW. A terceira fase seria tardia aos eventos metamórficos, com geração de dobras em geral quase simétricas, ocorrendo restritamente em afloramentos ou zonas dentro de afloramentos. Em vários domínios, a terceira fase consiste em dobramentos holomórficos com dobras abertas e normais a quase-normais, com comprimento de onda entre 600 a $1000 \mathrm{~m}$, e amplitude de 250 a 500m. A orientação dos traços axiais e eixos desta fase é de EW a NE com mergulhos para NE e para $W$, e em alguns domínios, as dobras exibem comportamento cônico.

Outras duas fases de dobramentos pós-metamórficos foram inferidos pela autora, através do tratamento estatístico de medidas e das relações entre clivagens tardias. Essas são, a fase do Sinclinório de Pirapora, com eixo mergulhante a N60-70E, e a fase tardia NS-NNW.

A hipótese de serem dobras de origem tectônica para as estruturas observadas no afloramento de crostas ferruginosas da Estrada dos Romeiros em Pirapora do Bom Jesus (Área - 3), possivelmente associadas a reativação dos grandes sistemas de 
falhamentos regionais (Taxaquara, Jundiunvira, Romeiros), está descartada. Através da geração de um sistema de falhas transcorrentes, em nível crustal raso, responsável pelo desenvolvimento de dobras cônicas do tipo plie de pantalon, estas dobras teriam que apresentar eixos iniciais a aproximadamente $45^{\circ}$ da direção das falhas, sendo estes ângulos progressivamente menores com a continuidade da deformação.

Podemos observar que isso não ocorre no afloramento estudado, já que os eixos construídos encontram-se, quase sempre, ortogonais a direção das falhas (no caso fraturas) (Figuras V.1.7, V.1.9, V.1.13 e V.1.15).

Outro fator importante é a inviabilidade da ocorrência de dobramento em material, como as crostas goethíticas descritas nesta dissertação. A incompetência deste material faz com que se rompa na presença de esforços tectônicos e não venha a sofrer dobramento suave ou apertado como se nota nesta área.
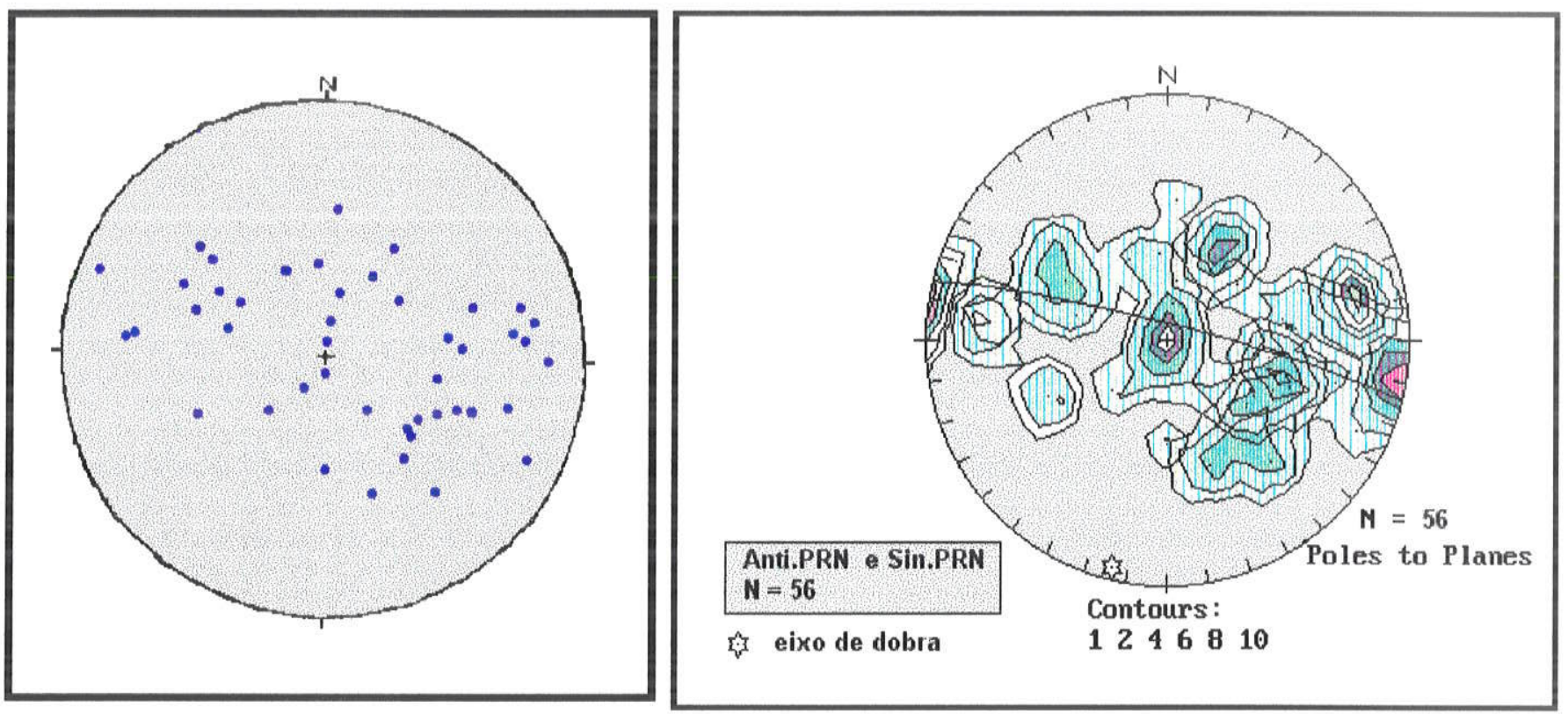

Figura V.1.6 - Estereograma de SchimdtLambert para os pólos dos flancos de

Figura V.1.7 - Curvas de contorno, guirlanda e eixo dobras do afloramento. construído para Figura V.1.6. 


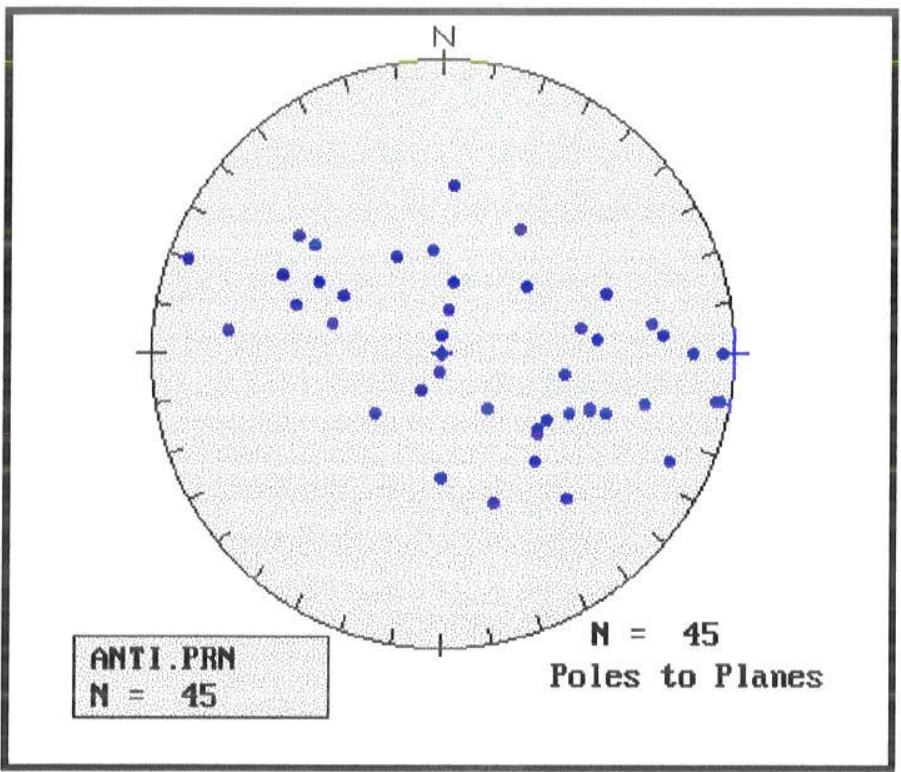

Figura V.1.8 - Estereograma de Schimdt-Lambert para os pólos dos flancos de dobras anticlinais do afloramento.

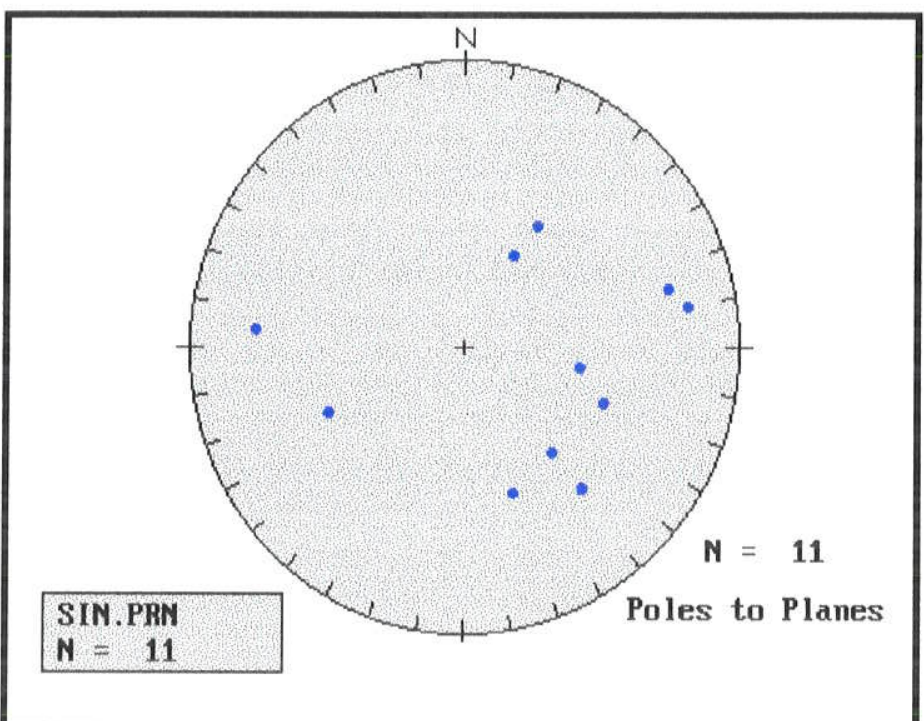

Figura V.1.10 -Estereograma de Schimdt-Lambert para os pólos dos flancos de dobras sinclinais do afloramento de Pirapora (Área 3).

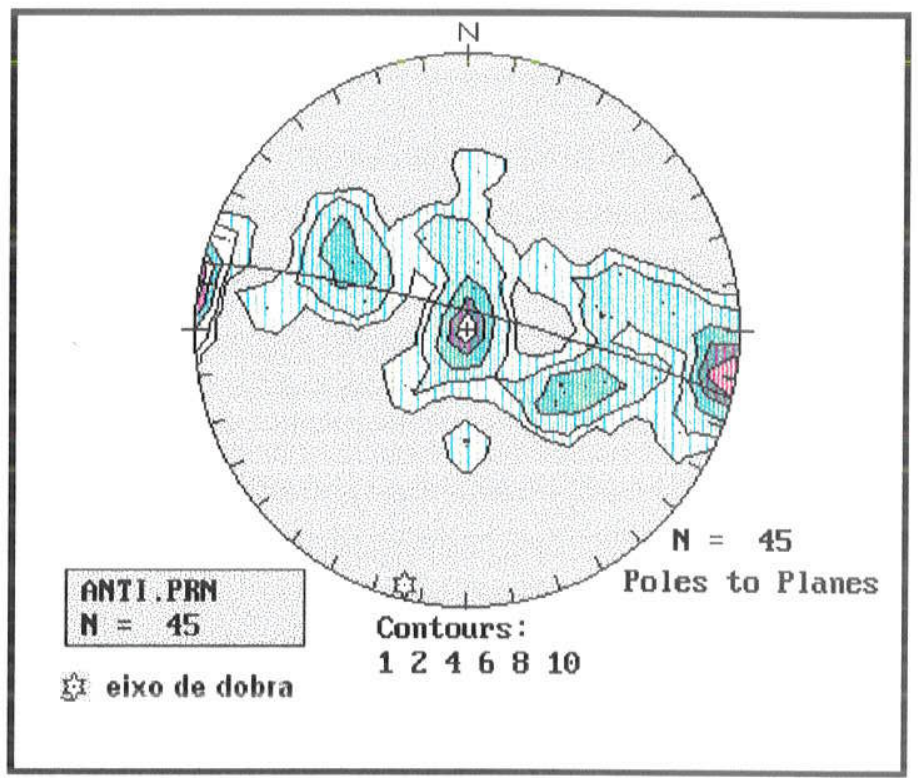

Figura V.1.9 - Curvas de contorno, guirlanda e eixo construído para Figura V.1. 8.

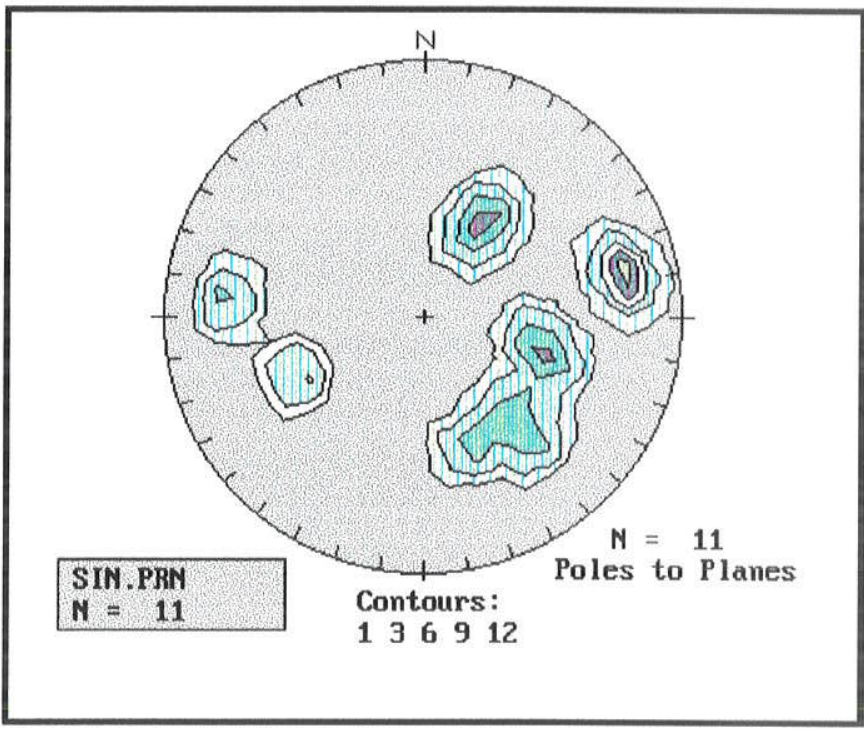

Figura V.1.11 - Curvas de contorno construídas para Fiqura V.1.10. 


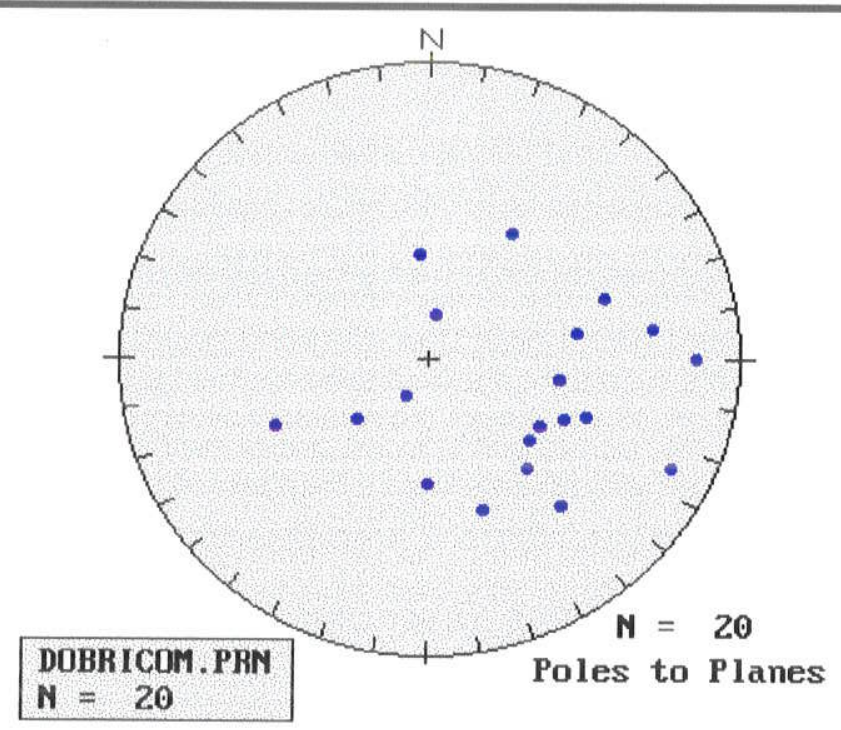

Figura V.1.12 - Estereograma de Schimdt-Lambert para os pólos dos flancos de dobras contidas entre FA e D1, especificados no croqui (Figura III.3) do afloramento de Pirapora (Área 3).

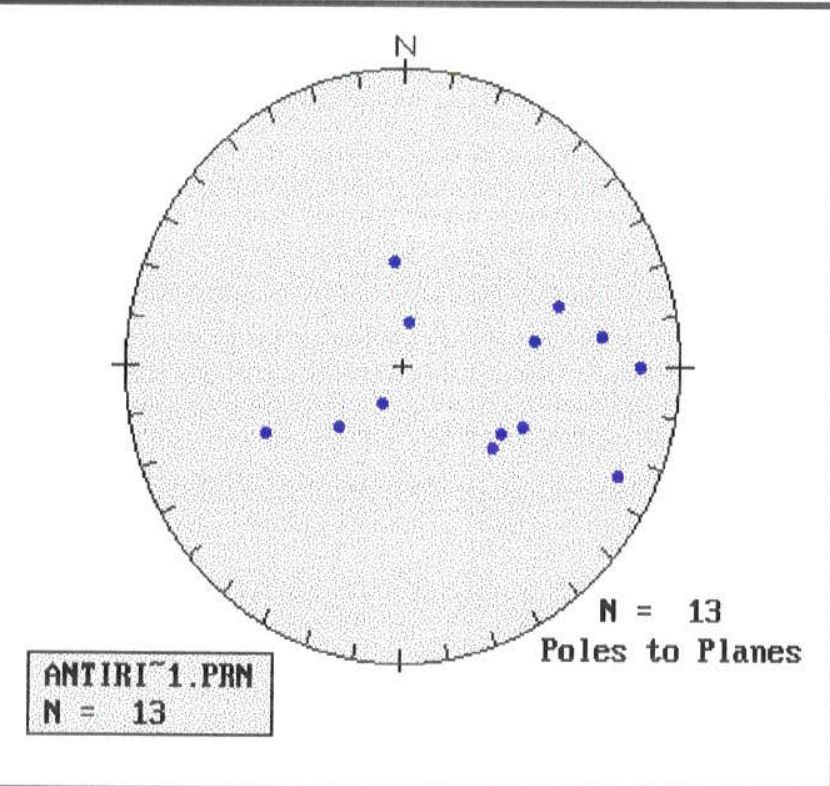

Figura V.1.14 - Estereograma de Schimdt-Lambert para os pólos dos flancos de dobras anticlinais, contidas na área delimitada por FA e D1, especificadas no croqui (Figura III.3) do afloramento.

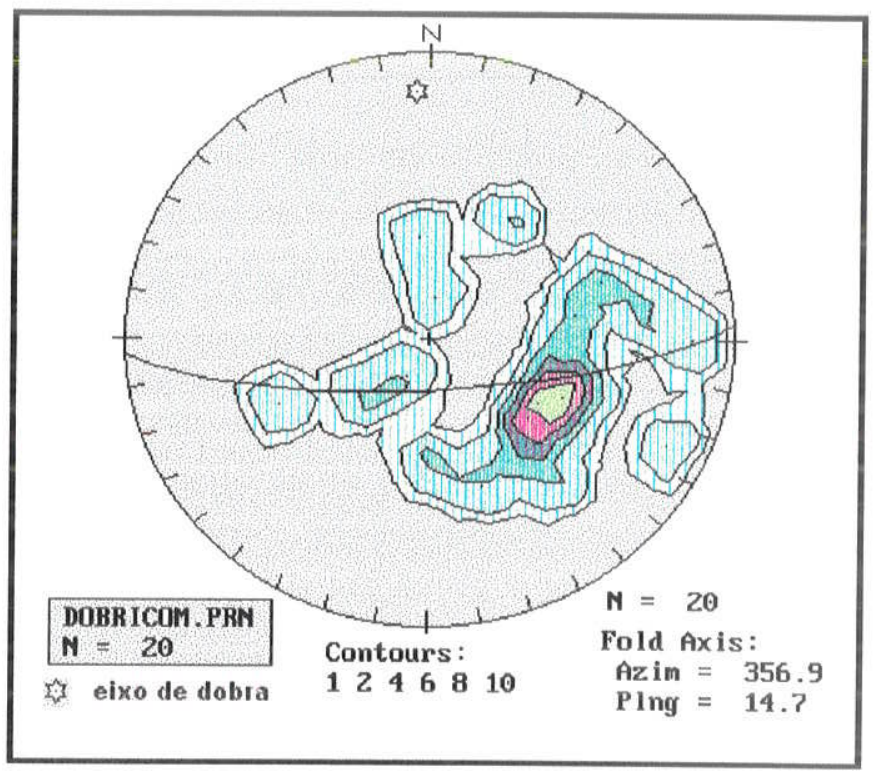

Figura V.1.13 - Curvas de contorno, guirlanda e eixo construído para Figura V.1.12.

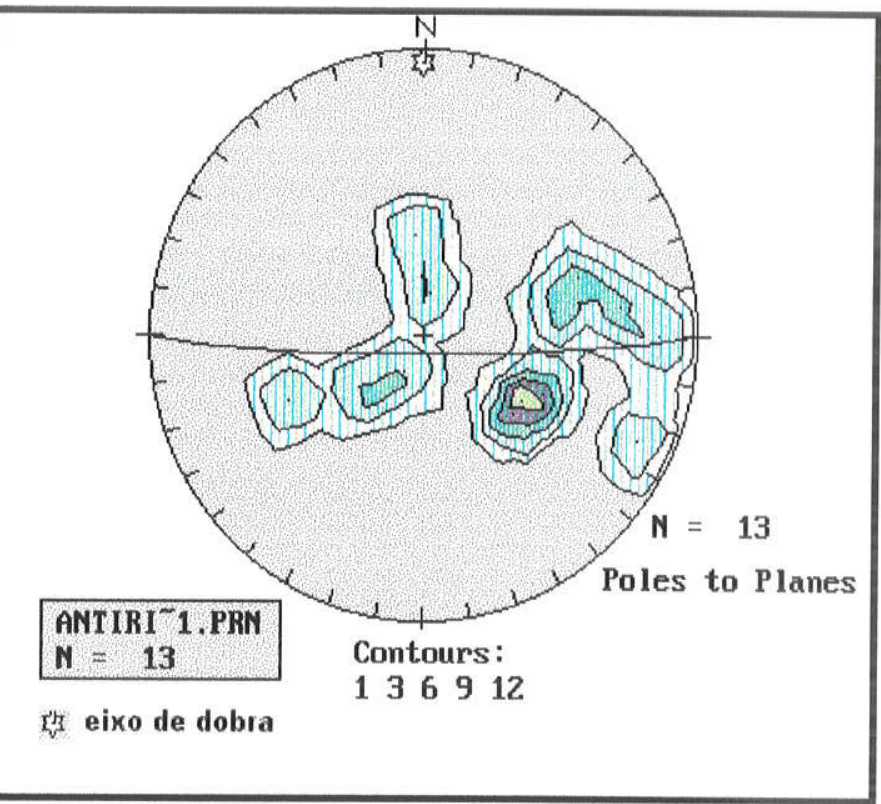

Figura V.1.15 - Curvas de contorno, guirlanda e eixo construído para Figura V.1.14. 


\begin{tabular}{|c|c|c|c|c|}
\hline DOBRA & CARACTERÍSTICA & TIPO & STRIKE & \\
\hline 1 & flanco esquerdo & sinclinal & 212 & 41 \\
\hline 1 & flanco esquerdo & sinclinal & 280 & 35 \\
\hline 1 & flanco esquerdo & sinclinal & 291 & 45 \\
\hline 1 & fla nco direito & sinclinal & 341 & 45 \\
\hline 1 & flanco direlto & sinclinal & 319 & 40 \\
\hline 1 & flanco direito & sinclinal & 319 & 55 \\
\hline 2 & fla nco esquerdo & anticlinal & 302 & 35 \\
\hline 2 & próximo a fratura & anticlinal & 175 & 29 \\
\hline 2 & prox. charneira & anticlinal & 30 & 12 \\
\hline 3 & fla nco esquerdo & anticlinal & 188 & 12 \\
\hline 3 & flanco direito & anticlinal & 310 & 35 \\
\hline 3 & flanco direito & sinclinal & 65 & 45 \\
\hline 3 & flanco esquerdo & anticlinal & 48 & 25 \\
\hline 4 & fla nco direito & anticlinal & 320 & 20 \\
\hline 4 & flanco direito & sinclinal & 210 & 30 \\
\hline 1 & charneira & anticlinal & $\mathbf{0}$ & 35 \\
\hline 5 & flanco direito & anticlinal & 260 & 40 \\
\hline 5 & flanco direito & anticlinal & 262 & 62 \\
\hline 5 & charneira & anticlinal & 250 & 50 \\
\hline 5 & fla ncoesquerdo & anticlinal & 115 & 40 \\
\hline 5 & flancoesquerdo & anticlinal & 115 & 75 \\
\hline 5 & fla nco esquerdo & anticlinal & 90 & 75 \\
\hline 6 & fla nco direito & sinclinal & 95 & 65 \\
\hline 6 & flanco esquerdo & sinclinal & 255 & 66 \\
\hline 6 & fla nco esquerdo & sinclinal & 260 & 71 \\
\hline 7 & charneira & anticlinal & 155 & 30 \\
\hline 7 & fla nco esquerdo & anticlinal & 108 & 44 \\
\hline 7 & flanco esquerdo & anticlinal & 280 & 85 \\
\hline 8 & flanco direito & anticlinal & 280 & 85 \\
\hline 8 & flanco direito & anticlinal & 265 & 65 \\
\hline 8 & fla nco direito & anticinal & 265 & 44 \\
\hline 8 & charneira & anticlinal & 190 & 20 \\
\hline 8 & fla nco esquerdo & anticlinal & 130 & 48 \\
\hline 8 & flanco esquerdo & anticlinal & 280 & 85 \\
\hline 9 & flanco esquerdo & anticlinal & 110 & 82 \\
\hline 9 & flanco osquerdo & anticlinal & 120 & 40 \\
\hline 9 & charnoira & anticlinal & 180 & 0 \\
\hline 9 & charneira & anticlinal & 232 & 30 \\
\hline 10 & flanco direito & anticlinal & 270 & 86 \\
\hline 10 & fla nco direito & anticlínal & 280 & 86 \\
\hline 11 & flanco esquerdo & anticlinal & 96 & 63 \\
\hline 11 & charneira & anticlinal & 5 & 5 \\
\hline 12 & flanco direito & anticlinal & 290 & 50 \\
\hline 12 & flanco direito & anticlinal & 290 & 45 \\
\hline 12 & fla nco direito & anticlinal & 280 & 85 \\
\hline 13 & flanco esquerdo & anticlinal & 184 & 48 \\
\hline 13 & charneira & anticlinal & 183 & 5 \\
\hline 13 & flanco direito & anticlinal & 284 & 61 \\
\hline 13 & flanco direito & anticlinal & 280 & 85 \\
\hline 14 & flanco esquerdo & anticlinal & 116 & 51 \\
\hline 14 & flanco esquerdo & anticlinal & 120 & 32 \\
\hline 14 & charneira & anticlinal & 180 & 0 \\
\hline 15 & fla nco esquerdo & anticlinal & 129 & 53 \\
\hline 15 & charneira & anticlinal & 180 & 0 \\
\hline 15 & flanco direito & anticlinal & 308 & 34 \\
\hline 16 & flanco esquerdo & anticlinal & 105 & 32 \\
\hline 3 & oixo & & 30 & 20 \\
\hline 5 & eixo & & 0 & 12 \\
\hline
\end{tabular}

Tabela V.1.2-Medidas das dobras do afloramento de Pirapora (Área-3) 


\section{DISCUSSÕES}

Os resultados obtidos nas análises por microscopia óptica de lâminas, análise de minerais pesados, Difratometria de Raio $X(D R X)$, análises químicas totais e pontuais (MEV/EDS), dos materiais coletados nos afloramentos da Dutra (Área 1), no afloramento da Vila Madalena (Área 2) e no afloramento de Pirapora (Área 3), permitem apresentar as seguintes consideraçōes:

No geral, a composição mineral das crostas ferruginosas e dos sedimentos encaixantes, são semelhantes. Dentre as diferentes feições observadas uma se destaca: grãos de quartzo parcialmente corroídos com evidência de dissolução. Estas feições de corrosão provém da dissolução da sílica promovida pela degradação química destes materiais, responsável também pela concentração de hidróxidos de ferro (ferralitização).

Em seção delgada observa-se, grãos, nódulos e litorelíquias, cimentados predominantemente por goethita nas crostas ferruginosas, e por caolinita nos sedimentos encaixantes. Foi possivel reconhecer a origem e a evolução de produtos secundários formados pela remobilização e concentração de hidróxidos de ferro como volumes principais e por hidróxidos de alumínio e argilas, ocorrendo como recobrimentos, nódulos e preenchimento de poros e de fissuras, como volumes secundários.

Embora não se tenha realizado análise de porosidade nos materiais coletados, as análises em microscopia óptica e em MEV permitiram interpretar que, a eliminação do ferro da rocha original, durante a migração dos hidróxidos de ferro, hidróxidos de alumínio e parte de argilas, proporciona aumento na porosidade destes sedimentos. Consequentemente a concentração de material argiloso em associação com hidróxidos de ferro, nas crostas, diminui a porosidade destes materiais.

Os diagramas geoquímicos discriminativos construidos sugerem haver uma origem comum para as crostas ferruginosas a partir dos sedimentos encaixantes. A diferença exibida nestes diagramas reflete-se apenas no empobrecimento de $\mathrm{Fe}_{2} \mathrm{O}_{3}$ e enriquecimento de $\mathrm{SiO}_{2}, \mathrm{Al}_{2} \mathrm{O}_{3}$, e elementos alcalinos na matriz, contrariamente ao 
observado para estes elementos nas crostas. Este fato sugere que as crostas se originaram a partir da cimentação de óxidos e hidróxidos de ferro remobilizados da própria rocha encaixante durante deslocamento descendente do nível hidrostático. Devido a este fato a matriz é menos ferruginosa e guarda componentes originais da rocha como elementos alcalinos e alumínio e as crostas são horizontes intensamente ferruginisados, onde predomina o ferro (30 a $50 \%$ ), na forma de óxidos e hidróxidos e a sílica (20 a $50 \%$ ) (Tabelas V.1, V.4 e V.13).

Onde ocorrem as crostas ferruginosas o sedimento encaixante se encontra deferruginizado. Este feição é observada em campo e é comprovada através dos resultados das análises químicas realizadas nos materiais coletados nas três áreas estudadas.

As análises químicas pontuais em MEV/EDS, confirmaram os resultados obtidos nas análises químicas totais, e nas análises mineralógicas. Os resultados dessas análises, demonstraram que no plasma correspondente as crostas, os picos de ferro são mais elevados, e que no plasma correspondente aos sedimentos encaixantes (matriz), os picos de silício e alumínio destacam-se. Foram encontradas nestes materiais, microfissuras, onde o alto teor de ferro detectado no interior das mesmas, indica processos de remobilização de óxidos e hidróxidos de ferro.

Acredita-se que as crostas arqueadas, com aspecto de pseudo-dobras, observadas nos afloramentos da Dutra (Área 1) e da Vila Madalena (Área 2), originaram-se a partir da migração hidróxidos de ferro através da deposição de sucessivas "frentes de precipitação" destes hidróxidos.

Períodos de elevada precipitação pluviométrica, associado à presença de ácidos húmicos proveniente da decomposição da matéria orgânica, nos horizontes superficiais do solo, favorecem a remobilização do ferro da rocha original. Fluxos d'água migram descendentemente na topografia em direção ao nivel hidrostático $(\mathrm{NH})$ carreando ferro e outros elementos solubilizados para porções inferiores do perfil de alteração. Ao encontrar condições favoráveis à precipitação, "frentes de oxidação" formam-se dando origem à zonas de deposição de hidróxidos de ferro. Este processo ocorre sucessivamente a cada novo período de precipitação pluviométrica mais intensa. 
A própria morfologia das "frentes de oxidação", fornece as crostas ferruginosas o aspecto de crostas dobradas similares a Anéis de Liesegang, como os observados nos afloramentos da Dutra (Área 1) (Figuras III.7 e III.8) e no afloramento da Vila Madalena (Área 2) (Figuras III.10, III.11 e III.12).

Segundo Suguio e Barbour, (1969), as frentes de deposição de hidróxidos de ferro possuem forma de arcos ou leques e, durante a propagação das mesmas, estas podem encontrar obstáculos representados pela diferença de permeabilidade dos sedimentos ou pela interceptação de outras "frentes" adjacentes, que acabam "deformando-as".

As crostas ferruginosas dobradas do afloramento de Pirapora (Área 3) aparecem justamente na porção do afloramento onde ocorrem distintos grupos de fraturas formados ora por fraturas únicas sem preenchimento (G1), ora por fraturas preenchidas por hidróxidos de ferro, com aproximadamente $10 \mathrm{~cm}$ de espessura (G2) (Figura III.13, $F 2, F 3, F 4, F 5, F 8$ e F9). Estas fraturas limitam a morfologia das crostas "dobradas".

O terceiro grupo (G3) é formado por conjunto de fraturas pouco espessas, com 2, 3 e 5 elementos, preenchidas por hidróxidos de ferro, possivelmente formadas por processos de reativação de fraturas preexistentes. Estas fraturas ora condicionam o fechamento das "dobras", ora cortam as mesmas (CF - Figura III.13).

As fraturas dos grupos G1, G2 e G3 do afloramento de Pirapora (Área 3), descritas acima teriam direcionado o fluxo d'água para o interior das mesmas, visto que a rocha mãe é pouco permeável e a existência de fraturas implicam diretamente em maior permeabilidade, propiciando maior percolação de água e passagem de materiais lixiviados por elas. Neste mesmo local, observou-se que, na porção onde não ocorrem fraturas (Figura III.13, perfis ST e CP), a distribuição da sílica, do ferro e do alumínio nos perfis é homogênea, não havendo zonas de concentração destes elementos.

Notou-se relativo empobrecimento em ferro nas crostas localizadas no topo dos perfis D2 e D3 (Figura III.13). Este fato deve-se ao "desprotegimento" das mesmas, dado pela couraça ferruginosa mais antiga, do topo do afloramento, que foi quase totalmente desmantelada por processos erosivos recentes (stone line de fragmentos de couraça 
depositados na porção NE do afloramento de Pirapora - Área 3, Figura III.13). O fluxo d'água constante promoveu lixiviação mais intensa destes horizontes. Isto não ocorre nas porções do afloramento, capeadas pela couraça do topo.

Não foi possivel a comprovação por análise estrutural a partir dos dados obtidos para as dobras do afloramento de Pirapora da associação das mesmas com algum padrão de dobra conhecido na literatura, como por exemplo, dobras de arrasto cônicas do tipo plié de pantalon, descritas em diferentes trabalhos na área estudada e aqui relacionados no capitulo V.1.

Deste modo, descarta-se a possibilidade de interpretação de uma origem tectônica para estas dobras em crostas goethíticas, associadas com a estrutura sinclinal de Pirapora, da qual poderiam ser dobras parasitas, posteriormente cortadas por falhas transcorrentes resultando na exposição apenas dos seus anticlinais.

Segundo Bergmann (1988), os planos verticalizados estudados por ela com mesmo comportamento estrutural das fraturas presentes no afloramento de Pirapora (Área 3), representariam clivagens de crenulação tardias associadas à estrutura sinclinal de Pirapora, tendo uma orientação plano axial em relação à mesma e presentes no extrado da charneira do sinclinal em seu flanco norte. A autora não menciona a feição aqui discutida, porém sua interpretação descarta a possibilidade destes planos verticalizados serem falhas transcorrentes, o que dificulta ainda mais a aplicação de modelos tectônicos para a formação das dobras em crostas ferruginosas aqui descritas.

Algumas evidências de campo demonstram que o relevo local encontrava-se abaixo do nivel topográfico atual. São: a linha de fragmentos de couraça (stone line) observada na porção NE do afloramento (Figura III.13) e a degradação da couraça superior.

Diante das oscilações ascendentes de relevo, o nível hidrostático $(\mathrm{NH})$ passou a se comportar de modo descendente em relação ao relevo. Períodos de maior umidade (chuvoso) conduzia o NH a porções superiores e nos períodos de seca a porções inferiores. No entanto o movimento relativo do $\mathrm{NH}$ era sempre descendente. Desta forma óxidos e hidróxidos de ferro da rocha original, foram remobilizados e 
concentrados em zonas subjacentes ao longo deste período ascensional do relevo. De tal forma que o material constituido principalmente por hidróxidos de ferro $e$ secundariamente por hidróxidos de alumínio e argilas se precipitassem ao longo das fraturas (F) dos grupos G1 e G2, observadas no afloramento de Pirapora (Área 3) (Figura III.13).

Crostas ferruginosas oblíquas às fraturas se formaram, a partir da estrutura tipo "pena" (cone de rebaixamento gerado pela ascensão do relevo - Figura VI.1 - Estágio 2). O conjunto formado pela junção dessas estruturas, caracteriza a feição de "dobras" apresentada no afloramento (Figura III.14).

Eventos tectônicos recentes promoveram a reativação dos sistemas de falhamentos regionais de Taxaquara, Jundiuvira e Romeiros produzindo novas fraturas, redirecionado o fluxo d'água para o interior das mesmas, formando os conjuntos de fraturas G3 (Figura III.13, CF). Posteriormente crostas dobradas antigas foram cortadas por falhas (G4) (Figura III.13, F7, F10 e F11), em também provável evento de reativação dos sistemas de falhamentos acima mencionados.

O modelo de evolução geoquímica proposto acima para as crostas dobradas de Pirapora do Bom Jesus, encontra-se ilustrado na figura VI.1. 

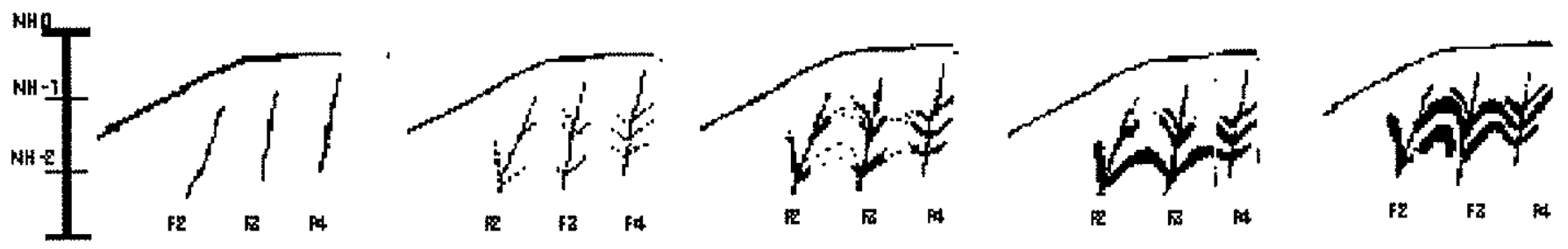

NH atual

Esquema (1) - Instalação das fraturas (F) por provável reativação tectônica moderna (quaternária) dos sistemas de falhamentos regionais de Taxaquara, Jundiuvira e Romeiros;

Esquemas (2 e 3) - Soerguimento do relevo, fazendo com que o nível hidrostático (NH0) se comporte de maneira descendente $(\mathrm{NH}-\mathrm{l})$, promovendo a remobilização de óxidos e hidróxidos de ferro da rocha original. $\mathrm{O}$ rebaixamento progressivo do nível hidrostático $(\mathrm{NH}-1$ e $\mathrm{NH}-2$ ) induz a água contida na litologia a buscar caminhos mais favoráveis de percolação, e as fraturas (F2, F3 e F4) são estes caminhos preferenciais. $\mathrm{O}$ condicionamento do fluxo d'água para o interior das fraturas, permite que óxidos $\mathrm{e}$ hidróxidos de ferro se precipitem ao longo das mesmas, formando crostas verticalizadas. Início da formação de estruturas tipo "pena" devido à precipitação de compostos de ferro, obliquamente às fraturas;

Esquemas (3 e 4) - As estruturas tipo "pena" vão se tornando mais espessas, devido à percolação e acumulação de material argilo ferruginoso;

Esquemas (4 e 5) - A continuidade dos processos de remobilização e concentração de óxidos e hidróxidos de ferro, promove a junção das estruturas tipo "pena" formadas em fraturas paralelas e muito próximas uma das outras. A união dessas estruturas fornece aspecto de crostas arqueadas.

Esquema (5) - O conjunto formado pela junção das estruturas tipo "pena" exibido aqui como modelo, representa a feição de crostas dobradas, encontradas na porção NE do afloramento de Pirapora (Área 3) (Figuras III.13 e III.14).

Figura VI.1 - Esquema evolutivo das crostas deformadas de Pirapora do Bom Jesus, baseado na proposta de origem geoquímica para estas estruturas. 


\section{CONCLUSÕES}

As crostas ferruginosas dos afloramentos da Dutra, da Vila Madalena e de Pirapora do Bom Jesus, apresentam organização textural, composição química e mineral semelhantes, embora se encontrem encaixadas em litologias distintas. Este fato sugere que as crostas são horizontes mais intensamente ferruginizados, originados a partir da cimentação por óxidos e hidróxidos de ferro provenientes dos próprios sedimentos encaixantes.

Mineralógicamente, as crostas ferruginosas estudadas não fogem a regra geral quanto a composição mineral, sendo a goethita, o hidróxido de ferro mais comum nestes materiais.

Não foi possível a associação através da análise estrutural dos dados extraídos do "dobramento" em crostas ferruginosas do afloramento da Vila Madalena com algum padrão de dobra de rochas ao redor da área, de origem sabidamente tectônica, devido ao próprio contexto tectônico e geológico da Bacia de São Paulo.

Os dobramentos encontrados nas crostas ferruginosas do afloramento de Pirapora do Bom Jesus, não exibem relações diretas com os padrões de deformação tectônica gerador dos padrões de dobras regionais reconhecidos e descritos em trabalhos inerentes a esta temática (Bergmann, 1988, Bistrich, 1982).

As crostas ferruginosas, são de origem genuinamente geoquímica, formadas por processos de remobilização e concentração dominante de óxidos e hidróxidos de ferro, e de modo secundário de hidróxidos de alumínio e diferentes argilo minerais, diante do deslocamento descendente do fluxo d'água e das oscilações do nível hidrostático $(\mathrm{NH})$. No caso do afloramento de Pirapora as oscilações do $\mathrm{NH}$, estão possivelmente relacionadas a variações climáticas sazonais, acompanhadas de movimentações tectônicas ascensionais modernas (Quaternário).

No afloramento de Pirapora, vale ressaltar a importância das fraturas instaladas por provável reativação tectônica (Quaternário) de sistemas de falhas regionais, as quais teriam propiciado o condicionamento do fluxo d'água para o interior das mesmas. A 
precipitação de hidróxidos de ferro no interior das fraturas e obliquamente as mesmas formou a estrutura tipo "pena" e, o conjunto formado pela junção destas estruturas delineia e forma a feição de crostas ferruginosas dobradas. 


\section{BIBLIOGRAFIA}

Almeida, F.F.M. 1955. As Camadas de São Paulo e a Tectônica da Serra da Cantareira. Bol. SBG, 4: 23-40.

Almeida, F.F.M. 1976. The System of Continental Rifts Bordering the Santos Basin, Brazil. Anais da Academia Brasileira de Ciências (suplemento), 48:15-26.

Araújo, E.S. ; da Costa, M.L. 1993. Mineralogia e geoquímica de superfície de crostas lateríticas derivadas de formações ferríferas (N1 - Carajás). In: SBGeoq., Cong. Bras. de Geoquímica, 4, Brasília, Resumos Expandidos, 1:198-200.

Araújo, E.S. ; da Costa, M.L. 1993. Geoquímica de superfície de platôs com latossolos (N5 - Carajás). In: SBGeoq., Congresso Brasileiro de Geoquímica, 4, Brasilia, Resumos Expandidos, 1:201-203.

Bergmann, M. 1988. Caracterização estratigráfica e estrutural da seqüência vulcanosedimentar do Grupo São Roque, na região de Pirapora do Bom Jesus. Inst. de Geociências, Universidade de São Paulo, São Paulo, Dissertação de Mestrado, $155 \mathrm{p}$.

Bergmann, M. ; McReath, I. 1992. Rochas vulcânicas do Grupo São Roque na região do Morro Boturuna em São Paulo. In: Jornadas Científicas, 2, São Paulo, Bol. IG -USP, Publ. Esp., 12:19-21.

Bistrich, C.A. 1982. Geologia do Sinclinório de Pirapora, SP. Inst. de Geociências, Universidade de São Paulo, São Paulo, Dissertação de Mestrado, 92 p.

Coppedê, A.J. 1988. Formas de relevo e perfis de intemperismo no leste paulista: aplicações no planejamento de obras civis. Escola Politécnica, Universidade de São Paulo, São Paulo,152p.

Costa, M.L. 1993. Proposta para sistematização do estudo de lateritos. In: SBGeoq., Congresso Brasileiro de Geoquímica, 4, Brasília, Resumos Expandidos, 1:195197.

Dantas, A.S.L. 1990. Geologia da Faixa São Roque e intrusivas associadas na região entre São Paulo e Mairiporã, SP. Inst. de Geociências, Universidade de São Paulo, São Paulo, Dissertação de Mestrado,199 p.

Delvigne, J. E. 1998. Atlas of Micromorfolgy of Mineral Alteration and Weathering. The Canadian Mineralogist, Special Publication 3, Orston, 494p.

Goudie, A. 1973. Duricrusts in Tropical and Subtropical Landscapes. Oxford, Clarendon, $174 \mathrm{p}$.

Hackpacher, P.C. ; Godoy, A.M. ; Oliveira, M. A. F. 1992. Geologia da Folha de Pirapora, SP, escala 1: 25.000. In: SBG, Congresso Brasileiro de Geologia, 37, São Paulo, Resumos Expandidos. 2:124-125. 
Hassui, Y. 1990. Neotectônica e aspectos fundamentais da tectônica ressurgente no Brasil. In: Workshop sobre neotectônica e sedimentação cenozóica continental no Sudeste Brasileiro, 1, Belo Horizonte. Bol. SBG-MG. 11:1-31.

Hills, E.S. 1972. Elements of Structural Geology, 2 ed, London, Methuen, 483p.

Hobbs, B.E. ; Means, W.D. ; Willians, P.F. 1976. An Outline of Structural Geology. New York, John Wiley, 571p.

Horbe, A.M.C. ; da Costa, M.L. 1993. Evolução mineralógica e geoquímica de perfil de solo derivado de crosta laterítica (N5 - Carajás). In: SBGeoq., Congresso Brasileiro de Geoquímica, 4, Brasília, Resumos Expandidos, 1:193-194.

IPT/PRÓ-MINÉRIO 1981. Mapa Geológico do Estado de São Paulo, escala 1:500.000.

Janasi, V.A. ; Andrade, S ; Ulbrich, H.H.G.J. 1995. A correção do drift instrumental em ICP-AES com espectrômetro sequêncial e a análise de elementos maiores, menores e traços em rochas. Série Científica, Bol. IG-USP, 26:45-58.

Juliani, C. ; Beljavsks, P. 1995. Revisão da litoestratigrafia da Faixa São Roque, Serra do Itaberaba, São Paulo, SP. In: Bol. IG-USP, 16:33-58.

Leinz, V ; Carvalho, A.M.V. 1957. Contribuição à geologia da Bacia de São Paulo. In: Bol. FFLCH - USP, 205:1-61.

Loczy, L. ; Ladeira E. A. 1980. Geologia Estrutural e Introdução a Geotectônica, Conselho Nacional de Desenvolvimento Científico e Tecnológico, Edgard Blucher, $528 p$.

Melo, M.S. ; Ricomini, C. ; Hasui, Y. ; Almeida, F.F.M.; Coimbra, A.M. 1985. Geologia e evolução do sistema de bacias tafrogênicas continentais do Sudeste do Brasil. Revista Brasileira de Geociências, 15:193-201.

Melo, M.S. ; Caetano, S.V.L. ; Coimbra, A.M. 1986. Tectônica e Sedimentação na área das Bacias de São Paulo e Taubaté. In: Congresso Brasileiro de Geologia, 34, Goiânia, Anais, 1:321-336.

Melo, M.S. ; Ponçano, W.L. ; Mook, W.G. ; Azevedo, A.E.G. 1987. Datações C14 em Sedimentos Quaternários da Grande São Paulo. In: ABEQUA, Congresso da Associação de Estudos do Quaternário, 1, Porto Alegre, Anais, 1:427-436.

Mendes, J. C. 1950. O Problema da Idade das Camadas de São Paulo. Bol. Paulista de Geografia, 5:45-48.

Mendes, J. C. 1984. Elementos de Estratigrafia, 2 ed., São Paulo, Edusp, 566p.

Mezzalira, S. 1962. Novas ocorrências de vegetais fósseis cenozóicos no Estado de São Paulo. Bol. Instituto Geográfico e Geológico, 15:73-94. 
Ohnuma, C.S. 1990. Couraças ferruginosas de recobrimento da Bacia de São Paulo: sua distribuição e composição lito-mineralógica. Resultados Preliminares. In: Jornadas Científicas, Bol. IG-USP Especial Trabalhos Apresentados.

Pettijohn, F. J. 1957. Sedimentary Rocks, New York, Harper e Row, 718p.

Price N. J. ; Gosgrove J. W. 1990. Analysis of Geological Structures, Cambrige University Press, 502p.

Sígolo, J.B. ; Ohnuma, C.S. 1996. Provável modelo de origem e evolução dos horizontes ferruginosos da Bacia de São Paulo com base na geoquímica de superfície. Bol. IG-USP, 27:137-149.

Suguio, K. ; Barbour, A.P. 1969. Morfologia e gênese das estruturas limoníticas dos sedimentos da Bacia de São Paulo. Anais da Academia Brasileira de Ciências, 41, 2:161-180.

Suguio, K. 1980. Rochas Sedimentares, propriedades, Gênese, Importância Econômica, São Paulo, Edgard Blucher, 262-272.

Suguio, K. 1980. Síntese dos conhecimentos sobre a sedimentação da Bacia de São Paulo. In: ABGE/SBG, Mesa Redonda Aspectos Geológicos e Geotécnicos da Bacia Sedimentar de São Paulo, São Paulo, Publicação Especial,1:25-32.

Riccomini, C. 1989. O Rift Continental do Sudeste do Brasil. Inst. de Geociências, Universidade de São Paulo, São Paulo, Tese de Doutorado, 256p.

Riccomini, C. 1995. Tectonismo gerador e deformador dos depósitos pós-gondwanicos da porção centro oriental do Estado de São Paulo e áreas vizinhas. Inst. de Geociências, Universidade de São Paulo, São Paulo, Tese de Livre Docência, 100p.

Sadowisk, G.,R. ; Tassinari, C.,C.,G. 1988. The São Roque volcano-sedimentary sequence of Proterozoic age. In: Intern. Gond. Symp., 7, São Paulo, Brazil, Excursions.

Salvador, E. D. 1994. Análise neotectônica da região do Vale do Rio Paraíba do Sul compreendida entre Cruzeiro S.P. e Itatiaia R.J. Inst. de Geociências, Universidade de São Paulo, São Paulo, Dissertação de Mestrado, 129p.

Takiya, H. 1991. Aplicação de métodos quantitativos espaciais a dados geológicos da Bacia de São Paulo. Inst. de Geociências, Universidade de São Paulo, São Paulo, Dissertação de Mestrado, 109p.

Takiya, H. 1997. Estudo da sedimentação Neogênico - Quaternária no Município de São Paulo; Caracterização dos depósitos e suas implicações na geologia urbana. Inst. de Geociências, Universidade de São Paulo, São Paulo, Tese de Doutorado, $152 p$. 
Tassinari, C.C.G. ; Kawaserita, K. ; Kikuchi, R. P. 1986. Estudos geocronológicos nos metaconglomerados do Grupo São Roque, no Estado de São Paulo. In: SBGNSP, Simp. Reg. de Geol., 5, São Paulo, Atas-SP, 1:201-208.

Turner, F.J. ; Weiss, L.E. 1963. Structural Analysis of Metamorphic Tectonite, McGraw, Hill.

Wernick, E. 1966. Análise granulométrica dos sedimentos da Bacia de São Paulo. Eng. Miner. Metal, 43:63-68. 